\title{
Weaving the contemporary position of Maatauranga Maaori within nursing practice
}

by

\section{Helen Taiaroa}

Ngaati Raukawa, Ngaati Kahungunu, Ngaati Tuuwharetoa, Ngaati Pikiao

A thesis submitted to the Victoria University of Wellington in fulfilment of the requirements for the degree of Doctor of Philosophy in Nursing

Victoria University of Wellington 2007 


\begin{abstract}
While the values and beliefs of health care for Maaori are perceived to be consistent with those which Maaori are embedded in, the outcomes developed from a Western worldview, has fallen short of this expectation. This thesis explores the customary kaupapa of Maatauranga Maaori or Maaori knowledge, which is the appropriate technique to determine how health care should be maintained by and for Maaori. The research highlights the need to meld these kaupapa with that of a contemporary Maaori viewpoint, to focus more on a deeper enhancement of these kaupapa, and develop an understanding of the social, cultural, educational, political and economic contexts these concepts have on Maaori as a people.
\end{abstract}

This research identified six Maaori registered women nurses, who willingly volunteered to share their experiences regarding Maatauranga Maaori and its importance to their nursing practice. Over a period of one year, in-depth conversations unfolded and produced data on what Maatauranga Maaori involves and how the six participants in the study believe it influences their nursing practices. All are currently practicing murses within various health settings such as psychiatric and comprehensive nursing, and all wish to be known by their given names.

From the inception of this study, the focus was to introduce Maatauranga Maaori as the epistemological framework of choice. Inclusive will be life-stories - oral stories - as the method by which value and insight are added to the progress of this research study. The findings of this research indicate that a collection of key kaupapa, namely whakapapa, whanaungatanga, te reo Maaori, wairuatanga, tuurangawaewae, manaakitanga and rangatiratanga are crucial to the health and wellbeing of Maaori as a people. These kaupapa enable Maaori to determine and strengthen our worldview, which in turn reflects the concept of being Maaori thereby contributing to the health and status of their whaanau, hapuu and iwi.

The findings support the view that there is a substantial collection of kaupapa, which are inherent in Maatauranga Maaori as being able to provide a framework for theoretical research. These kaupapa will provide a framework for nursing practice and educational curricula that will develop and maintain nursing standards to meet the needs of Maaori.

Key words: cultural diversity, Maatauranga Maaori, Maori health, life story. 


\section{Acknowledgements}

Writing and developing a doctoral thesis is at times exhausting and demanding. But these thoughts faded as the expression of manaakitanga and whanaungatanga of those whaanau, hapuu and iwi members who whakapapa to me was ever present.

To the six participants in this study - Kim, Ani, Te Ata, Hineroa, Margaret and Aroha - my aroha and thanks for your generous time, understanding, trust, laughter, whakapapa and life-stories. Without this there would be no thesis. Your contribution is significant to the understanding of what and how Maatauranga Maaori is important to the health and wellbeing of Maaori as a people.

To my primary supervisor, Rose McEldowney, words cannot express how grateful I am to you for your support and encouragement. My secondary supervisor Jan Duke who stepped in when needed, my gratitude and thanks.

To you Uncle Iwi for being there and doing things that ensured that I had the hapuu support and Uncle Whatarangi, thanks for your tenacity to insist I finish this project.

Thanks to Mason Durie and those who supported my application for sponsorship, which allowed me to continue uninterrupted in completing this thesis at a crucial time in the research. Thanks also to my hapuu Ngaati Pareraukawa for their koha to complete this work.

Kahukura - no amount of words can express my gratitude to you for your personal time to transcribe all of these participants' conversations without wanting any remuneration.

To my children Rochai, Melanie, Chanel and Chad, thank you for your support and interest in this project. Those comments of 'have you not finished yet Mum?' and 'how long now?' were appreciated. To my three mokopuna Toby, Jada and Georgia 'love and kisses' from Nanny.

Last but more importantly, George without your unfailing and unresounding patience and love, I wouldn't be where I am today. Special thanks for just being there and caring. 


\section{Table of Contents}

\section{Preliminary pages}

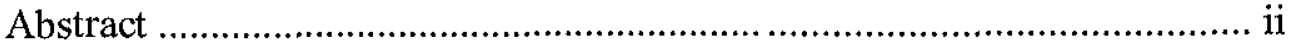

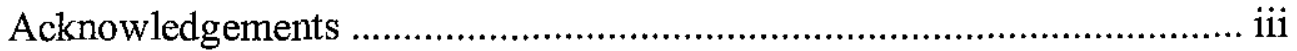

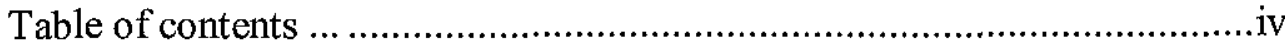

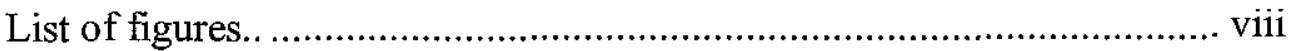

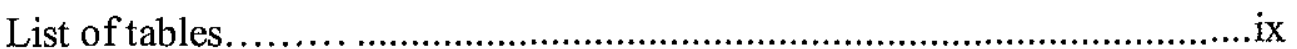

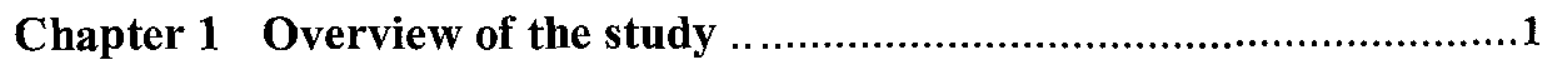

Why did I choose this research study? ................................................5

Purpose of the research question and study .........................................

Literature Review..................................................................... 10

Challenges..................................................... 11

Appropriate framework for this research study....................12

Use of Maaori academic written work, including the oral approach...12

Use of the word conversations. ....................................................13

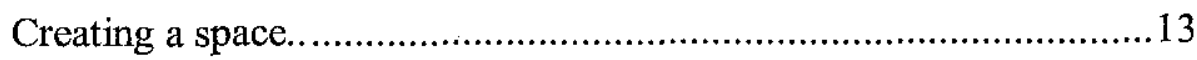

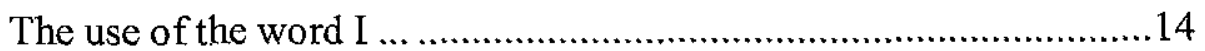

My voice matters alongside of the six participants ...........................14

Reflection and experiences of the six participants ............................15

The theory of Maaori as a people ..................................................15

The word Maaori means ordinary or normal .................................16

Indigenous writers and researchers work......................................16

The contribution of a Maaori transcriber ....................................... 17

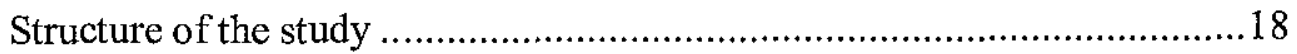

Chapter 2 Maatauranga Maaori: Maaori knowledge.................................24

Section 1 - The kaupapa embedded in Maatauranga Maaori .............26

Mythology, tikanga, kaupapa and iwi histories .....................................27

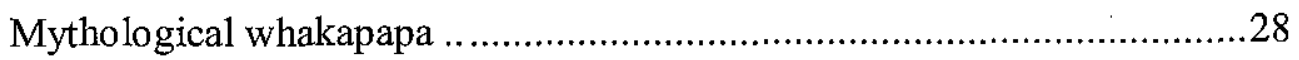

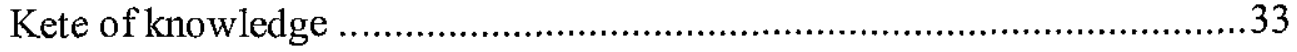

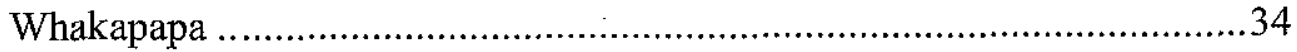




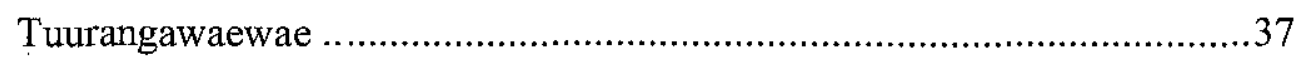

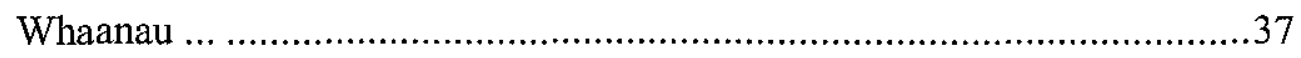

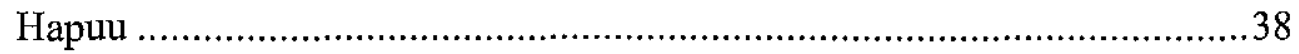

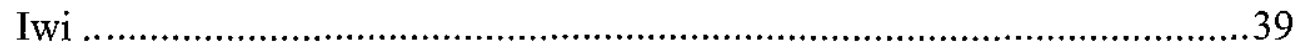

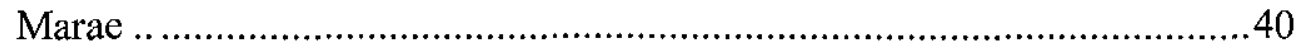

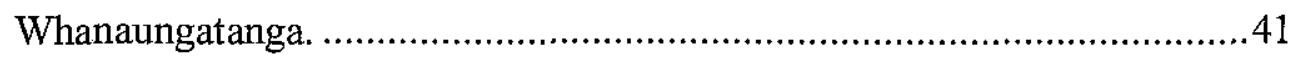

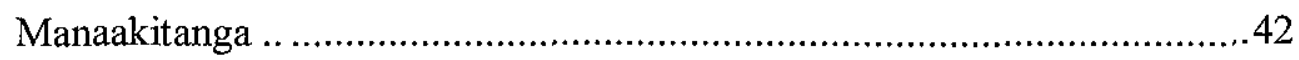

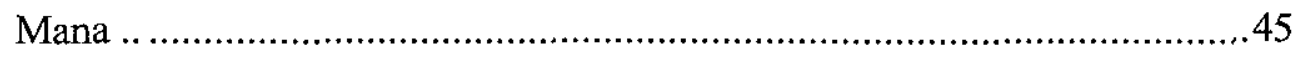

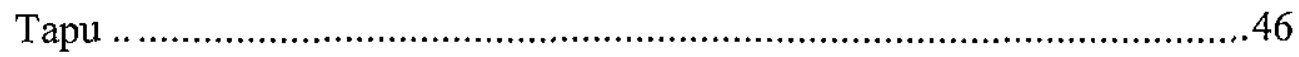

Noa

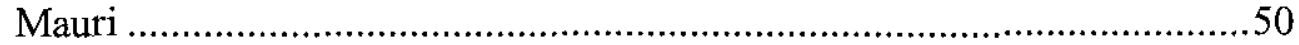

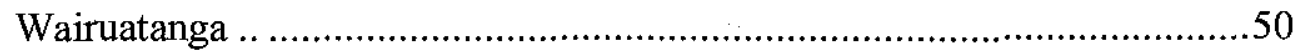

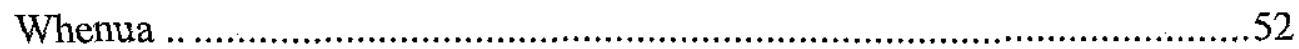

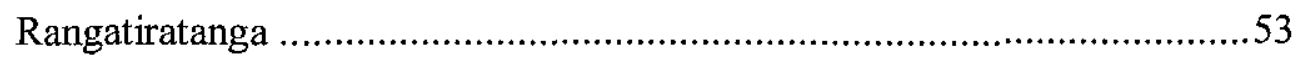

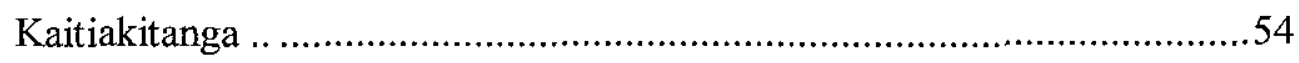

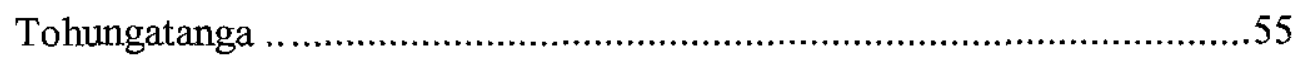

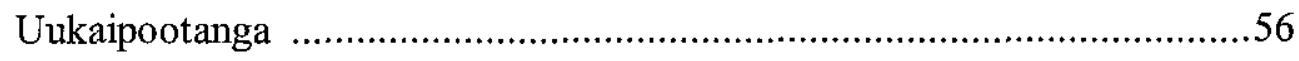

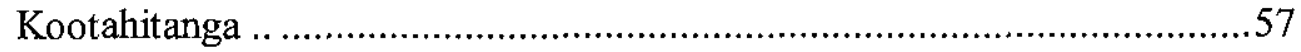

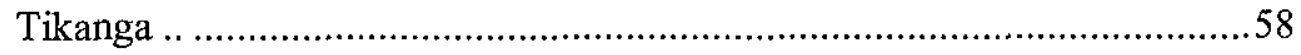

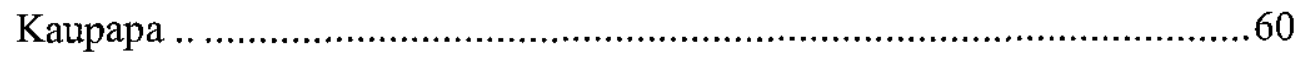

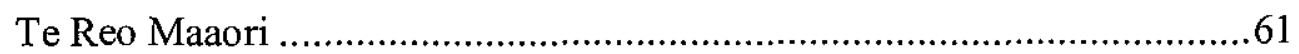

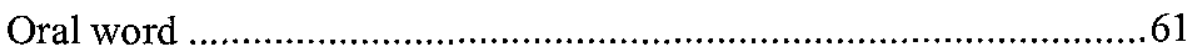

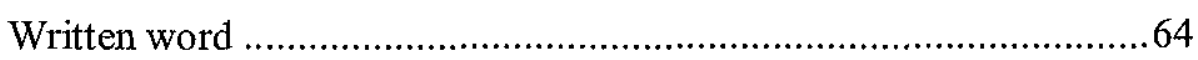

Section 2 - Customary Whare Waananga...............................................70

Summary of chapter ............................................................................

Chapter 3 Theoretical framework, methodology and design ...............73

Section 1 - Introducing the framework for this study.............................76

Maatauranga Maaori as the framework for this research study....................76

Role of the researcher from a Maatauranga Maaori continuum. .................79

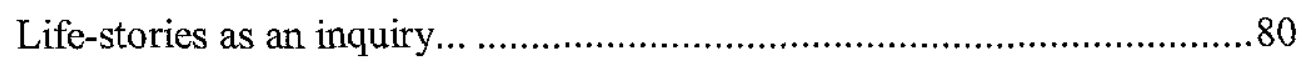

The researcher's personal view on storytelling................................81 
Charles Royal's view of stories from a Maatauranga Maaori

Continuum

Usage of life-stories by Maaori nurse researchers.

The doing or ontological position from a Maaori nurse researchers position

The knowing about or epistemological position from a Maaori nurse researchers position

Issues of methodological rigour ..... .88

Life-stories - oral stories and their application to this research study. .......90

Research design .91

Seeking ethical approval for the research study ....................................92

Selecting participants for the research ................................................93

Section 2 - Research Process...........................................................95

The beginning of the pathway with the six participants..............................95

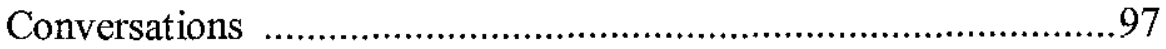

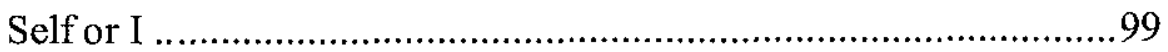

Space 100

Weaving as a holistic metaphor and its application to this research study

Whakapapa a life-story framework for recommencing the participant's conversations.

Gathering the stories from the participants

Analysing and interpreting the life-stories

Writing the whakapapa story section

The process or phase of creating kaupapa themes

Development of the kaupapa themes

Reflection on rigour from a Maatauranga Maaori continuum

Summary of chapter

\section{Chapter 4 Weaving the whakapapa and life-stories of the six participants.}

Whakapapa story of Kim.. 125

Whakapapa story of Ani.

Whakapapa story of Te Ata.

Whakapapa story of Hineroa. 156 
Whakapapa story of Margaret.

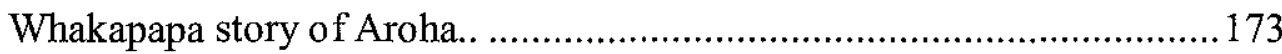

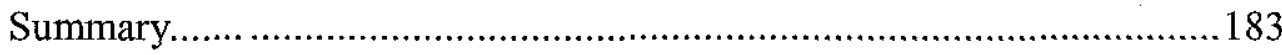

Chapter 5 Life-stories: 'Being Maaori' is 'who and how I am'............. 187

'Being Maaori' is 'who I am' and 'how I am' ................................190

The location and identity of whakapapa .............................................. 192

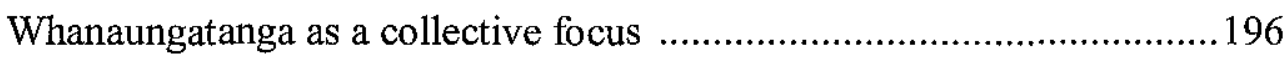

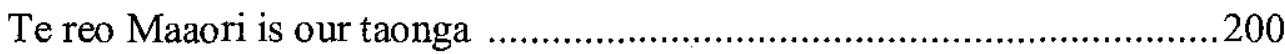

Wairuatanga as a spiritual kaupapa ...................................................204

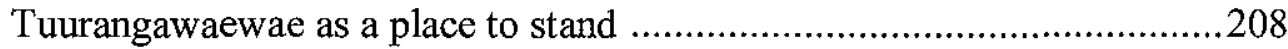

Manaakitanga and the expression of hospitality ...................................212

Rangatiratanga as a means of maintaining successive generations ..........216

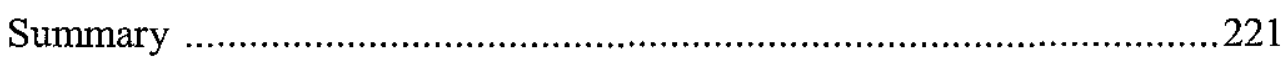

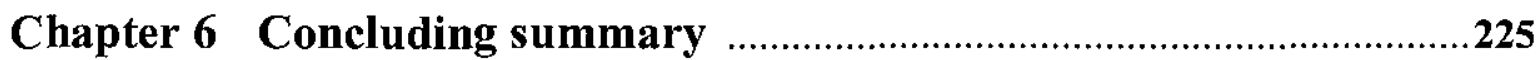

The positioning of the research .......................................................225

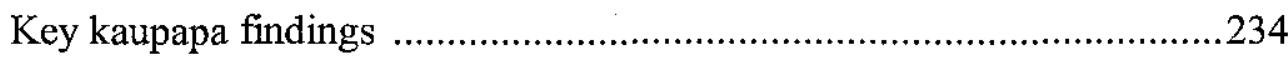

Proposition resulting from the research .........................................235

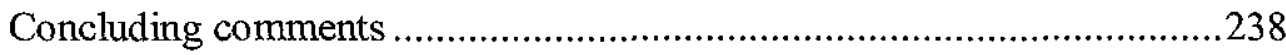

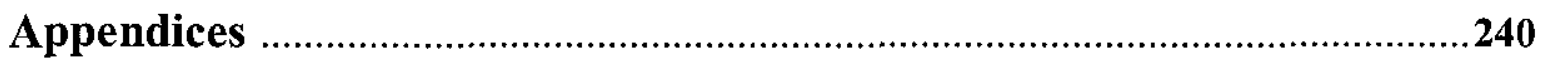

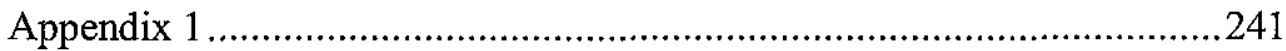

A copyright note on the artwork of Chanel Raewyn Taiaroa

Appendix 2

Iwi location map

Appendix 3

Memorandum from Convener VUW HEC, re: ethical approval to undertake $\mathrm{PhD}$ research project 


\section{List of figures}

Figure 1 Te Kore represented within mythology 29

Figure 2 Papatuuaanuku and Ranginui embracing ………….................................30

Figure $3 \quad$ Researcher's whakapapa …………………..........................................36

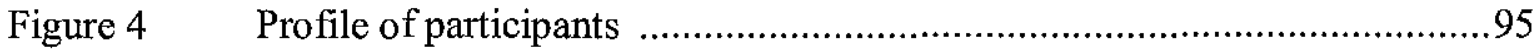

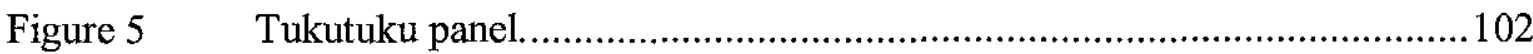

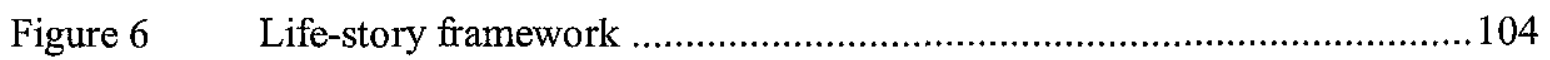

Figure $7 \quad$ Whakapapa, whanaungatanga and kootahitanga......................................122

Figure $8 \quad$ Aroha's tuurangawaewae ………………........................................173

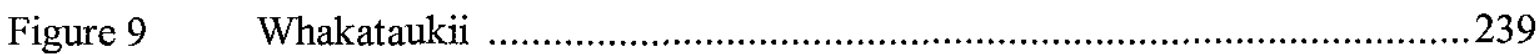




\section{List of tables}

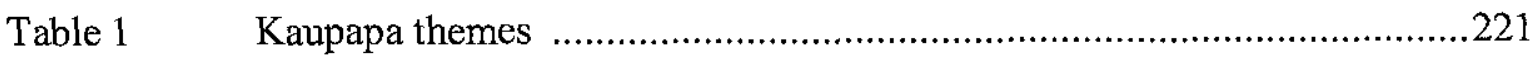




\section{Chapter 1 Overview of the research study}

The arrival of Maaori $^{1}$ to the shores of Aotearoa ${ }^{2}$ heralded the introduction of concepts known as Maatauranga ${ }^{3}$ Maaori. This knowledge formed the basis by which Maaori ensured their health and wellbeing were sustained. The influx of Paakehaa ${ }^{4}$ settlers, missionaries, traders and whalers to this land in the eighteenth and nineteenth centuries saw a steady decline in the Maaori population, due to the epidemic illnesses these newcomers carried (Dow, 1999). The introduction of tikanga (values) and kaupapa (principles) not associated with a Maatauranga Maaori continuum ${ }^{5}$ were also part of the repression of Maaori (M. Durie, ${ }^{6}$ 1998). The suppression of te reo Maaori (Maaori language) as a means of communication was also enforced (Selby, ${ }^{7} 1999$ ) during these periods. It is these events and their consequences that may have led to the annihilation of Maaori but with determination and endurance, they fought back from this situation (Lange, 1999). What can be determined is that one of the major impediments to the health and wellbeing of Maaori has been the displacement of Maatauranga Maaori by Paakehaa, who have compelled Maaori to accept health care, which is unsuitable and, in many circumstances, contradictory to Maaori tikanga and kaupapa.

\footnotetext{
${ }^{\mathrm{I}}$ Cleve Barlow (2003, p. 70) states "Maaori is the name given to the Indigenous people of New Zealand. The origin of the name is not known, but the Maaori are supposed to have referred to themselves as Maaori well before the arrival of Paakehaa".

${ }^{2}$ Aotearoa is the Maaori name for New Zealand and translated means the land of the long white cloud.

${ }^{3}$ Maatauranga means Maaori knowledge. It is through this knowledge that Maaori gain insight into their worldview and what it means for them.

${ }^{4}$ Cleve Barlow (2003, p.87) states that "Paakehaa is the name that was given by Maaori to the white skinned immigrants who came from the United Kingdom and settled in Aotearoa".

${ }^{5}$ Professor Whatarangi Winiata (2006) contends that taken together, the words Maatauranga Maaori continuum relate to our accumulating knowledge across the ages and includes all refinement, enrichment and enhancement of our understanding. It reminds us that what we understood yesterday will be a little different from what we understood today and tomorrow's understanding will be different again. We may not notice this from day to day but from decade to decade and from century to century the accumulating differences will become apparent. The concept of Maatauranga Maaori continuum tells us that our worldview is dynamic. We know this to be the case because our worldview is the product of experience. Our people were observes of their world and they provided explanations that satisfied them. In addition, they had the intellectual capacity to store their knowledge. Changing experiences lead to changing explanations and in this context the notion of contemporary Maatauranga has a whakapapa (genealogy) that is long while also being fresh and relevant to expressing the most recent experience of significance. To use the word perspective is too slender in its interpretation. It does not do justice to the concept of weaving contemporary Maatauranga, which has a long whakapapa, into nursing practice. The word perspective is superficial in its rendition of the research study being explored, hence, the usage of Maatauranga Maaori continuum.

${ }^{6}$ Known as Mason Durie and of Ngaati Kauwhata, Ngaati Raukawa and Rangitaane iwi (tribal) affiliation. He is the Assistant Vice Chancellor (Maaori) of Massey University, and is Professor and Head of Te Puutahi $o$ Toi, School of Maaori studies at Massey University, Palmerston North, Aotearoa.

${ }^{7}$ Known as Rachel Selby of Ngaati Raukawa, Ngaati Huia and Ngaati Porou iwi affiliation. Selby holds graduate qualifications from Massey University, Palmerston North, Aotearoa. She is a writer and researcher.
} 
The overall aim of this thesis is to recreate recognition of Maatauranga Maaori and its relevance to nursing practice. To achieve this aim, I intend to:

- give voice to the everyday practices of Maaori registered women nurses by sharing their stories of the what and how that influences them and by applying Maatauranga Maaori within nursing practice

- understand and develop how to undertake nursing research from a Maatauranga Maaori continuum

At the outset Maatauranga Maaori will be the epistemological framework used, incorporating life-stories - oral stories - as the way forward for this research study. Both approaches complement and endorse the view that life-stories - oral stories are valuable means of gaining insight into the questions being asked and are a way of honouring the contribution from each participant. As a kaupapa Maatauranga Maaori is not new, but as a framework for research in nursing it is a new concept. A significant number of respected Maaori academics (Black et 1, 2003; Carter, 2004; Cunningham; 2000; A. Durie, 1998; E. Durie, 1994; M. Durie, 2000; Glover, 1997; Jackson, ${ }^{8}$ 1988; Marsden, ${ }^{9}$ 2003; A. Meads, 2001; Mikaere, ${ }^{10}$ 1995; C. Royal ${ }^{11}$, 2004; Stokes, 2004; Walters, 2004; J. Williams, 2004; P. Winiata, 2005; P. Winiata, 2006 and, W. Winiata, ${ }^{12} 2005$ ) encourage the renewal of this concept into the field of studies. The oral stories disclosed at a hui (meeting) held at Ngaatokowaru marae (ceremonial courtyard) in 2006 by the repositories of knowledge who whakapapa to this hapuu (sub-tribe) support this viewpoint (for example M. Davis, ${ }^{13} 2006$;

\footnotetext{
${ }^{8}$ Known as Moana Jackson and of Ngaati Kahungunu iwi affiliation. Jackson holds graduate qualifications from Victoria University of Wellington.

${ }^{9}$ Known as Maaori Marsden and of Ngaa Puhi iwi affiliation. Marsden was a graduate of the Ngaa Puhi Whare Waananga (School of knowledge) and a holder of an Honours degree in theology. He was concerned with the fundamentals, the foundations of our existence, and more particularly, forging new understandings, and new ideas so that our future can be cemented in something of enduring worth and value. Marsden found direction in both the Maaori past and his Christian faith.

${ }^{10} \mathrm{Known}$ as Ani Mikaere and of Ngaati Raukawa, Ngaati Huia and Ngaati Porou iwi affiliation. Mikaere holds a Master's of Jurisprudence from Waikato University, Hamilton, Aotearoa.

${ }^{11}$ Known as Charles Te Ahukaramuu Royal and of Ngaati Raukawa, Ngaati Tamatea and Ngaa Puhi iwi affiliation. Royal holds a (B Mus (Hons) M. Phil, $\mathrm{PhD}$ ). He is a composer, writer and researcher.

${ }^{12}$ Known as Whatarangi Winiata and of Ngaati Raukawa and Ngaati Marutuahu iwi affiliation. Winiata holds a (B.Com), from Victoria University of Wellington and further qualifications (MBA, $\mathrm{PhD}$ ), from the University of Michigan as a Rotary Foundation Fellowship student. He is married to Francie and they have four children, Pakake, Huia, Petina and Kimo and numerous mokopuna (grandchildren).

${ }^{13}$ Known as Margaret Rangimakaora Davis and of Ngaati Raukawa and Ngaati Marutuahu iwi affiliation. She would be considered a repository of knowledge in this present day.
} 
R. Jacobs, ${ }^{14}$ 2006; J. Selby, ${ }^{15} 2006$ and, I. Nicholson, ${ }^{16}$ 2006). These oral commentaries disclose the historical and customary application regarding how Maaori viewed the world. This ensured that the health and wellbeing of Maaori was maintained.

There are Indigenous ${ }^{17}$ writers and researchers who share the same view, which is that values and beliefs associated with one's worldview should show the pathway to conducting research. Some of these writers are Afigbo, (1981), Au, (1997), Behrendt, (1993), Brewster, (1996), Bulan, (2005), Egudu, (1981), Eshkakogan and Half, (2005), Drabek, (2005), Goold, (2005), Kahakalau et 1, (2005), Kawa, (2001), Lee, (2005), Morris, (1996), Tamasese, et 1, (2005) and, Winch, (2005).

A search of both national and international literature revealed nothing had been written on Maatauranga Maaori in relation to nursing practice. What I did uncover is data written on Maatauranga Maaori related to other disciplines such as politics, education and medicine (M. Durie, 1999; Glover, 1997; Jones, 2000 and, Turia, 2005). Two Maaori nurse educators Maureen Holdaway (2002) and Denise Wilson (2004) conducted their research from a Kaupapa Maaori perspective, which is inherent in Maatauranga Maaori. According to Graham Smith" ${ }^{18}$ (1997, p. 45) "Kaupapa Maaori is a way in which Maaori describe practices and philosophies about Maaori". There are other Maaori academics that have used Kaupapa Maaori as a way in which to frame their studies for example, L. Pihama (1993), and, L. Smith ${ }^{19}$ (1995), to name a few. It will be this literature and texts written by other Maaori academics that will form the basis of this research

\footnotetext{
${ }^{14}$ Known as Ranfurly Te Maharanui Jacobs and of Ngaati Raukawa, Ngaati Huia and Ngaati Porou iwi affiliation. Ranfurly holds a (BVSc), and (MACVSc), from Sydney University, Australia. He would be considered as a repository of knowledge in this present day.

${ }^{15}$ Known as Joanna Selby and of Ngaati Raukawa, Ngaati Huia and Ngaati Porou iwi affiliation. Joanna is a registered comprehensive nurse. She would be considered as a repository of knowledge in this present day.

${ }^{16}$ Known as Iwikaatea Nicholson and of Ngaati Raukawa iwi affiliation. Uncle Iwi would probably best describe himself as a person that has no formal qualification except that bestowed on him by his $i w i$. He then would be considered a repository of knowledge in this present day.

${ }^{17}$ Within this research the use of capital I will be identified for the word Indigenous. It allows me to acknowledge the mana (respect) and mauri (life force) of those Indigenous writers and researchers, whose works I will be including in this study.

${ }^{18}$ Known as Graham Hingangaroa Smith and of Ngaati Apa and Ngaati Porou iwi affiliation. Smith holds a $\mathrm{PhD}$ from the University of Auckland. He was the original writer regarding the concept of Kaupapa Maaori as a research framework. He is married to Linda and they have a daughter.

${ }^{19}$ Known as Linda Tuhiwai Te Rina Smith and of Ngaati Awa and Ngaati Porou iwi affiliation. Smith holds a $\mathrm{PhD}$ from the University of Auckland. She is an Associate Professor in Education and Director of the International Research Institute for Maaori and Indigenous Education at the University of Auckland. Smith is married to Graham.
} 
methodology/theoretical framework. Included will be the contribution of oral commentaries.

Also included will be those Paakehaa academic writers such as Judith Binney, (2005), Michael King, (1997), Joan Metge, (1995), Margaret Orbell, (1998), John Patterson, (1992) and, Peter Snedden (2005), all of whom have contributed to the vast array of literature around Maaori perspective and culture. There are Paakehaa nurse educators and researchers who have contributed to the knowledge base of storytelling (for example, Harker, 2000; Johns, 1995; Martin, 2000; McEldowney, 2002, O'Reilly, 2002 and, Rochford, 2004). Besides nurse educators and researchers, there are other researchers in social sciences who have used life-stories - oral stories as part of their research methodology journey. These include Atkinson, (1998), Gudmunsdottir, (1995), Miller, (2000), Peacock and Holland, (1993) and, Pratt and Fiese, (2004).

Exploring a topic that has limited literature and attempting to introduce a new framework, brings numerous challenges. But these challenges for Maaori nurses need to be researched and explored so that our people can be confident that a secure and meaningful way of caring for Maaori within a health setting is available to them. Linda Smith (1992) contends the challenge for Maaori women in the 1990s is to assume control over the justification of our struggles and to begin to theorise our awareness in ways, which makes sense to us.

For the most part, research and the challenges associated with it for Maaori are done in a confident and determined manner. But, I suggest as a Maaori researcher that it is time we revived and renewed the way in which we conduct our research and the methodological frameworks we use. Without this, the care we envisage for our people will still be given from a Western viewpoint. I contend in this research study that health care for Maaori needs to be from a Maatauranga Maaori continuum.

In the main research studies have a start and an end but I need to commence with the statement in the beginning and ask the questions why, what, how and where I decided to undertake this research study. There are I believe, a variety of reasons for this decision. What experiences have I had which would inform my decision to journey into this terrain of academic understanding? How could I hope to achieve this pursuit while in a political 
climate that is tumultuous as the best of times, especially with regard to Maaori issues? Why would I contribute a large part of my personal time to go after this idea? Where and in which University setting should this research be undertaken? To sufficiently answer these questions, I need to explain: 1) why I commenced this research; 2) the research questions I wanted to answer; 3) literature review; 4) the challenges associated with writing on a topic that has not been attempted before, particularly from a Maatauranga Maaori continuum around nursing practice and, 5) the structure of the chapters and what can be gained by the reader when they examine each chapter at the end of this study.

\section{Why did I choose this research study?}

Before commencing this, I will discuss some background concerning my personal and professional journey and what attracted me to undertake such a research study. There are several reasons that have contributed to why I wish to undertake this research study. They arise from my experience as a student nurse, registered nurse, postgraduate student and Kaihautuu (Director), of Hauora ${ }^{20}$ studies at Te Waananga o Raukawa ${ }^{21}$.

First, during the 1970 s and 1980 s I practiced as a Maaori registered community nurse, which introduced me to Maaori and Paakehaa patients. What I observed in practice was that the health beliefs and practices of Maaori were not recognised or acknowledged by health professionals. Also the opportunities to develop these beliefs and practices of Maatauranga Maaori were limited. During this period, nursing education and practices were informed by Western beliefs. I needed to further my own understanding and knowledge around Maatauranga Maaori before I was able to encourage other colleagues to gain insight into a Maaori worldview. So I decided to participate in further nursing education and enrolled in a comprehensive undergraduate programme which I completed in 1997. During this time (early 1990s) Kawa Whakaruruhau/Cultural Safety became a key area of influence in education and nursing practice (Ramsden, ${ }^{22}$ 1992). The aim of cultural safety is to educate nurses to study their own cultural truths so that with self-knowledge they can be more open minded in the delivery of services to people of other cultures.

\footnotetext{
${ }^{20}$ Hauora means the breath of life. The English interpretation of the word means health.

${ }^{21}$ Te Waananga o Raukawa is a Maaori University, situated at Otaki. Professor Whatarangi Winiata was instrumental in setting up this waananga. As a waananga its philosophies and values are guided by those kaupapa inherent in Maatauranga Maaori.

${ }^{22}$ Known as Irihaapeti Ramsden of Ngaai Tahupootiki, Rangitaane and Ngaati Irakehu iwi affiliation. Ramsden holds a PhD from Massey University, Palmerston North, Aotearoa. She was the architect of the nursing educational process known as Kawa Whakaruruhau/Cultural Safety in Aotearoa.
} 
Kawa Whakaruruhau is also informed by Maaori tikanga and kaupapa inherent in Maatauranga Maaori (Walker, ${ }^{23}$ 1996). So this became a turning point in my nursing education as it engaged my thinking and writing around this topic from the writings of Maaori academics (for example M. Durie, 1989; R. Pere, 1997; B. Puketapu, 2000 and, L. Smith, 1992), which influenced my desire to continue the journey of discovery about Maaori and their worldview and consider how this might influence my practice.

Second, following graduation I obtained a position within the Acute Psychiatric Inpatient Unit at Hastings Hospital, Hawke's Bay. Again I noticed a disproportionate number of Maaori patients being admitted to this area for mental health care, and the lack of formal knowledge that was evident about caring for Maaori. The small number of Maaori nurses engaged in caring for Maaori patients knew how to care for our people from a Maatauranga Maaori continuum but I questioned the lack of knowledge of Paakehaa and some Maaori in these settings. I also believed because we were Maaori nurses, allocation of the Maaori patients became our major responsibility. This again led me to question the lack of appropriate and safe care being given to Maaori. Because of the insights gained within these health settings, as well as the whanaungatanga (relationships) developed with Maaori nurses, we began to exchange stories about our experiences. For example, one particular story relates to a Maaori woman aged sixty years being admitted because of violent behaviour. What Paakehaa staff had not understood was that she had recently lost her husband, and forgotten to take medication for bi-polar affective disorder. She was assessed and given a mixture of drugs to treat her illness, but no detail was noted about her whaanau (family) loss and the effect this had on her mental state. This and many other similar practice experiences highlighted the lack of awareness about delivering culturally safe care and practice, from a Maatauranga Maaori continuum.

Third, as a result of gaining an undergraduate nursing qualification and securing a position in the Acute Psychiatric Inpatient Unit at Hastings Hospital, Hawke's Bay, in 1999, I was selected to enrol in the Postgraduate Certificate in Advanced Nursing (Mental Health) at Victoria University of Wellington. This programme enhanced my understanding of, and

\footnotetext{
${ }^{23}$ Known as Ranginui Walker of Whakatoohea, Opootiki. Walker holds qualifications from Auckland Teachers Training College and the University of Auckland. He was chairman of the Auckland District Maaori Council for fifteen years and a member of the New Zealand Maaori Council for twenty years. Walker has written many papers on Maaori education, culture and politics and has contributed regular columns to the New Zealand Listener and to Metro magazine. He is married to Deidre and they have three children.
} 
ability to link theory to practice, and enabled me again to increase understanding of my values, beliefs and practices that were critical to the health and wellbeing of Maaori. More importantly it was a turning point for me as it allowed the recognition of different types of nursing knowledge to be recognised and applied, for example, a Kaupapa Maaori perspective. The academic knowledge gained during this time supported my decision to enrol in the Master of Arts (Applied) Nursing programme in 2000 and at the same time I gained employment as Kaihautuu of the Hauora Department at Te Waananga o Raukawa. During my Master's study I was exposed to various papers about nursing knowledge and its application to practice. There were two papers that made an impact on me. One was Nurs 515 Health research methods in nursing and midwifery, which enabled me to explore Kaupapa Maaori as a methodological framework. Linda Smith (1999) contends that Kaupapa Maaori framework for research are based on the assumption that research that involves Maaori people, as individuals or communities, should set out to make a positive difference for the researched.

At the same time I also began to explore the concept of Maatauranga Maaori, which embodies our understanding of the Maaori worldview from a customary period and ties this into a contemporary position. Maatauranga Maaori is steeped in customary practices and passed on by oral transmission through various forms of haka (posture dance), mihimihi (introductory speech) ${ }^{24}$, oriori (lullabies), karakia (prayer), karanga (welcome call), mooeteatea (lament), pakiwaitara (tales), waiata (songs), whakapapa ${ }^{25}$, whakataukii (proverbs), whaikoorero (formal speech) and other forms of communication. It is through these stories and songs with the accompanying music that Maaori come to understand how

\footnotetext{
${ }^{24}$ While conducting conversations with the six participants they identified they knew their whakapapa. The method to acknowledge this is known as tararere. To reflect their understanding the participants will use the technique known as mihimihi. They are aware that this is the means by which Maaori would normally introduce oneself. The participants were comfortable and confident to illustrate their whakapapa through this technique. This will be demonstrated in Chapters 4 and 5 .

${ }^{25}$ Joe Te Rito $(2007$, p. 8 ) states that there are many different technical terms used with whakapapa. First, "whakamoe: this is to show the intermarriages of the lines of descent, as opposed to taotahi, which gives the names on the lines without those of their wives or husbands. Second, tararere: this is to trace a single line of descent from an ancestor, without showing intermarriages, or giving other kin on the line. This is the usual method of tracing and you will find it adopted in the whakapapa book extant. Third, tahu: as the term connotes is setting out the main lines. In another sense it refers to the stock ancestors of a tribe. Thus Paikea, Paoa, Ira, Toi, Uepohatu and Ruawaipuu would be called stock ancestors of Ngaati Porou and kindred tribes. Finally, whakapiri: literally to seek to establish connection with. If you wish to define your position in respect of some person tracing from a common ancestor you count the generations down to him and yourself. If you should be on the same line, you have to consider whether he or you are of the elder branch, so that you can call him tuakana (elder) or taina (youngest). On the other hand you may stand to him in the position of paapaa and have to call him 'tamaiti' (child)".
} 
we view the world. Over time, as past, present and future generations engage with Maaori knowledge, this knowledge is shaped and reshaped. The second paper was Nurs 511 Nursing Knowledge, which included identifying my aesthetic of practice, which enabled me to demonstrate how I viewed the world through Maaori eyes. My presentation involved showing and discussing the kete (basket) of knowledge and its contribution to Maatauranga Maaori. The result of completing these papers and being employed by Te Waananga o Raukawa, ensured that the experiences I gained informed how I worked with Maaori students, Maaori registered nurses, kaiawhina (teachers) and those associated with managing Maaori who access health services.

Also, as part of the course requirements I completed a research paper Maaori women and wellness, which explored how to care for Maaori women from a wellness rather than an illness perspective. What began to emerge was how Maaori women not only gained or retained wellness from a Maatauranga Maaori continuum, but more importantly it identified how health and wellness of a Maaori woman's whaanau, hapuu and iwi is integral to her health and wellbeing. Kaupapa Maaori as a research framework was also introduced and explored within this paper. However, the size and scope of a thirty-credit point paper limited the extent to which I could explore a Kaupapa Maaori perspective. One key outcome of the study is that it raised the question for further exploration - if Maaori women identified the key aspects of Maatauranga Maaori as being important to their health and well being, how might Maaori registered women nurses integrate this within their practice? I decided to extend my thinking around how Maaori nurses might apply Maatauranga Maaori within their day-to-day practice and how I could engage with them in an appropriate and safe way so they would share stories about how this occurs.

Fourth, in $2003 \mathrm{I}$ applied to commence a Master of Nursing research thesis. My reason for entering this pathway was to develop my thinking and writing about Maatauranga Maaori because the one-paper research project had not offered the size and scope for this to occur. I developed a proposal, and a working title was created - Weaving the contemporary position of Maatauranga Maaori within nursing practice. I subsequently converted this to $\mathrm{PhD}$ enrolment and transferred into the doctoral programme. 
I commenced the thesis in March 2004 and since that time I have drafted six chapters, obtained ethics approval, gathered data in relation to the epistemological framework of Maatauranga Maaori and the life-stories - oral stories method to be used. I have completed the conversations with the six participants. Preparation for the redrafting of the second and third versions has been undertaken to allow final submission of this research study.

At one point I considered applying Kaupapa Maaori as the methodological framework for the study. However, as I have been reading, writing and unfolding the historical layers around this topic, I now recognise that Maatauranga Maaori is the holistic ${ }^{26}$ and overarching position that holds and connects the threads of customary and contemporary Maaori knowledge, which includes tikanga and kaupapa, as just some of the many threads. It is appropriate that I commence this study using a Maatauranga Maaori approach because of its holistic position and the way in which it will provide a deeper conceptual epistemological framework for the study.

\section{Purpose of the research question and study}

To give purpose to this research study, it is important to revisit the questions being asked: What are Maaori registered nurses' understandings of Maatauranga Maaori in relationship to nursing practice? How do they apply these understandings in nursing practice? These questions give voice to the whakapapa and life-stories of the six participants and give purpose to the research study being undertaken.

To achieve this, I engaged with six Maaori registered nurses currently in practice who have a strong desire to find answers to the research questions being asked. Giving voice to their experiences and relating these thoughts enabled the theory about their whakapapa and lifestories to emerge and is captured in Chapters 4 and 5.

I have ensured as the researcher that a thorough search of the literature available has been undertaken, both in the national and international arena. The literature review will identify what is acknowledged or not acknowledged about whakapapa and life-stories of Maaori

\footnotetext{
${ }^{26}$ To understand the tikanga and kaupapa embedded in the word holistic and how it is positioned in regards 'being Maaori', includes the concepts of wairuatanga and whanaungatanga. Further understanding can be gained around these concepts and how they are interwoven when reading Chapters 2, 3, 4 and 5 .
} 
registered nurses who practice from a Maaori worldview. What became evident from the review was that there is no specific material about the lives of Maaori nurses whose nursing practices reflect Maatauranga Maaori, nor does any of the existing literature address the research questions identified here. From the onset, I selected Maatauranga Maaori as the epistemological framework and life-story - oral stories as a method to bring together the thoughts and ideas of the what and how that may emerge from these conversations with the six participants. Using a whakapapa and life-story approach became a sign post which not only directed but addressed the research questions, allowing a pathway for these key kaupapa themes to emerge in this thesis. Conversations became the mode of transmission through which to gain this insight.

\section{Literature Review}

A literature review is the gathering of written data needed in research studies. For the purpose of this study I have chosen Maatauranga Maaori as the epistemological framework; oral stories play an important part of this undertaking. Maatauranga Maaori is the study of Maaori knowledge, which explains, predicts and embeds Maaori in their worldview. To achieve this, the oral stories, which were committed to their memory, were the means by which this was accomplished - all of which reflects the holistic nature of this approach. The development of oral stories for this research is positioned from a Maaori worldview, inclusive of Indigenous opinions and, as such, would not be considered a theoretical method from a Western worldview (Hemsley, 2004). To help the reader consider what oratory means, it is important that the researcher outlines why this is a valid method of gathering and presenting the knowledge used in this study.

Since its inception the oral means of transmitting knowledge has been an enormous part of Maaori society, and has led to Maaori writers (for example Davis, 2006; Grace, 2006; Jacobs, 2006; Meads, ${ }^{27}$ 2003; Nicholson, 2006; Ohia, 2004; Pere, 1982; Potiki, 1992; Te Rito $^{28}$, 2007; J. Selby, 2006; Whaitiri, ${ }^{29}$ 2006) expressing the value that this type of

\footnotetext{
${ }^{27}$ Known as Hirini Moko Meads and of Ngaati Awa and Ngaati Tuuwharetoa iwi affiliation. Meads was instrumental in establishing Te Whare Waananga o Awanuiaarangi, the Maaori University based at Whakataane. He is married to June Te Rina.

${ }^{28}$ Known as Joe Te Rito and of Ngaati Hinemanu, Ngaati Kahungunu and Rongomaiwaihine iwi affiliation. Te Rito holds a PhD from the University of Auckland.

${ }^{29}$ Known as Reina Whaitiri and of Ngaai Tahu iwi affiliation. Her mother is of English, Scots and Germany ancestry. She taught English literature at the University of Auckland and is currently co-teaching a course on
} 
communication has held for Maaori people. Indigenous writers and researchers indicate the value they place on the oral stories associated with their values and beliefs (for example Csak, 2002; Dubreuil, 2005; Hodson, 2005; Kahakalau, 2005; Melesis, 1990; Morgan, 1987; Narogin, 1990; Okello, 2006 and, Pawan, 2005). All support this stance.

Creating awareness about the preservation, transformation and transmission of knowledge belonging to Maaori was through oral means. It was through this form of communication that stories were told and retold allowing Maaori to become proficient storytellers. In the main, these were women. The significance of te reo Maaori is huge as it is this medium which facilitated Maaori mythology, iwi histories, hopes, challenges, dreams and desires to be communicated to each other. The formal process conducted on a marae, engages in the delivery of the oral language, which holds this customary aspect alive and allows Maaori to be who they are in the world today. It allows the worldview in which our tuupuna (ancestors) aspired before the introduction of the written word. It is this customary application and aligning it with the contemporary viewpoint of Maatauranga Maaori, which needs to be revitalised for the wellbeing of Maaori. Within these concepts is the key to unlocking answers that will be forthcoming in the whakapapa and life-stories of these six participants, disclosed in Chapters 4 and 5.

There are numerous challenges associated with this viewpoint but if this research states that Maatauranga Maaori is the epistemological framework for this study then it must be understood that oral customs were of absolute necessity, a major part of this undertaking. While this is intended to be an insightful experience, the aim is to provoke debate and challenge the spirit regarding the what and how Maaori do things the way they do through the use of oral stories - which is no less important than the written facts, which this method uses. To aid the reader some of these challenges will be outlined.

\section{Challenge}

To deeply understand Maatauranga Maaori, many challenges were considered while writing this research study. I have outlined a selection of challenges that arose when undertaking a research topic such at this. I will endeavour to summarise some of them and position them in a way, which will allow this study to unfold from the worldview of being

Maaori literature and culture at the University of Hawail at Manoa. Whaitiri has very close whakapapa connections to my husband George Charles Taiaroa. 
Maaori. Linda Smith's (1996) doctoral work contributed to the application of these kaupapa within this section:

\section{Appropriate framework for this research study}

In positioning Maatauranga Maaori as the way in which to frame this study does not preclude other possibilities for this type of research. Nor is it a matter of random choice of using any methodology. The oral commentaries and written accounts that validate this viewpoint, are inclusive of the whakapapa and life-stories of the six participants. Revealing this allows the reader to form an opinion about the way in which Maaori frame research that discloses our worldview. It also encourages Maaori researchers to be confident that the concepts associated with a Maaori worldview can be used as a framework for our studies; concepts such as whakapapa, te reo Maaori, manaakitanga (hospitality), whanaungatanga, wairuatanga (spirituality), kaitiakitanga (guardian) and kootahitanga (unity), to name but a few. For the reader to gain further understanding of these concepts is crucial to recognising a Maaori worldview. My introduction in the $1970 \mathrm{~s}$ to care being demonstrated to Maaori, which was not what I felt the most appropriate form of care, motivated me to seek to make changes. This journey has led me to the present point I am at, which is constructing a epistemological framework, namely Maatauranga Maaori, for consideration as a way in which to frame this research study.

\section{Use of Maaori academic written work, including the oral approach}

From the beginning, this research study stated that the oral accounts which have been disclosed by various Maaori, both academic and non-academic Maaori supported and enhanced the development. This will be part of the research study. Customarily, haka, karakia, karanga, mihimihi, mooeteatea, waiata, whakapapa ${ }^{30}$ and whakataukii were some of the way in which Maaori demonstrated their understanding of how Maaori viewed the world. A disciplined memory was considered easier and a great part of how Maaori retained this knowledge. The marae with its many taonga (treasures), whakairo (carving), tukutuku (lattice work), whaariki (floor mats) and any other important means of conveying oral concepts are part of this understanding. It was not until the introduction of European traders and missionaries in the eighteenth century that Maaori came to know and understand the written word. Included in this viewpoint are the many conversations

\footnotetext{
${ }^{30}$ Ranginui Walker (2007) contends that whakapapa is the epistemology of 'being Maaori'. There are many aspects that interlink into the concept of whakapapa and this will be outlined in Chapters 2, 3, 4 and 5 .
} 
conducted with people who access Te Waananga o Raukawa as a contemporary educational institute, allowing the way we distribute knowledge from this viewpoint to be valued and endorsed.

The number of contemporary Maaori academic writers undertaking doctoral work, is small. This then reflects the small quantity of writings by contemporary Maaori academics and non-academics that are referenced in this study. These writings are important to this research because it will allow it to be positioned from the contemporary viewpoint, as this is the world the six participants know, and the position that I come from as the researcher.

Another aspect to be considered is that of the word plagiarism and its explanation in relationship to the research being conducted. Because plagiarism is a word in the English language that defines the lack of acknowledging work belonging to others, this does not hold the same interpretation within a Maatauranga Maaori continuum. This is due to the tikanga of the gifting of written work and those oral accounts, which we regard as a taonga. The tikanga and kaupapa that is entrusted with these works also ensure we uphold and recognise such a taonga, even if this is not portrayed in the way expected by the Western academic viewpoint when undertaking academic studies and presenting scholarly writings. The challenge is to recognise these facts and to produce academic work that reflects and endorses our worldview with its credibility within Maatauranga Maaori.

\section{Use of the word conversations}

To gather the whakapapa and life-stories of these six participants, the word 'conversations' best describes the mode by which this is conducted. 'Interviews' is the word used to describe how most data is collected, but for the benefit of this research and the six participants involved, the challenge is to reflect the value of conversations as the means by which to gather these whakapapa and life-stories, which will be outlined in Chapters 4 and 5.

\section{Creating a space}

The ability to create a space in which these six participants were happy to conduct these conversations was important. Whether they wanted these conversations to be conducted on their marae, in their homes or a personal space of their choice, was their choice and various options were made available to them. Further discussion around this is outlined in 
Chapter 3, and the challenge therefore was to ensure that what the participants required as far as the correct space was made available to them.

\section{The use of the word I}

Writing, reading and creative activities are part of the interwoven lines in this research study. The use of the word I within this study has been a new experience and a struggle. Within the way Maaori view the world, we operate as a collective in anything we do including that of academic writing and research studies (Bishop, 1996; L. Smith, 1999). When stories are told reference is made to those tuupuna, one's whaanau, hapuu and iwi influences that contribute to the understanding around the importance of the collective being involved. To use the word $\mathbf{I}$ in reference to oneself within this research study, as being the person who is all knowing indicates that the focus is not on the collective; this is difficult to come to grips with. We then struggle within ourselves to achieve and enhance this Western viewpoint and this is where the challenge begins. More importantly if we were to assume similar patterns of writing and expressing our viewpoint from this particular position of thinking, we would be moving away from a Maaori worldview. This would have an impact on the health and wellbeing of our people as we adopt this type of thinking and writing, which we incorporate into our research.

\section{My voice matters alongside of the six participants}

Throughout this research study I have attempted to explore the six participants' whakapapa and life-stories. Through the use of conversations, literature will be gathered that will allow the reader to gauge what are Maaori registered nurses' understandings of Maatauranga Maaori in relationship to nursing practice? And, how do they apply these understandings in nursing practice? Seeking answers to these questions and being able to understand them as well as analysing and interpreting them in a way that makes sense to this study. This is the biggest challenge of all. In using my own voice in this research study, it is not my intention to claim any authority about the study, but to infer that it matters. There are the six participants who have whakapapa and life-stories to relate, which will shape and unfold what is needed to gain an understanding of this research topic. I find the constraints of viewing events in an impartial and detached manner difficult; consequently I felt it is important that whakapapa and life-stories from my viewpoint needed to be included. The use of my own voice at times throughout this study will allow 
me to reflect on my own stories but also to allow the acknowledgement of those stories of the six participants.

\section{Reflection and experiences of the six participants}

As well as being able to enlighten health professionals about the direction nursing practice should be moving towards in relation to Maaori, the type of care to be offered, and from which worldview; these six participant's whakapapa and life-stories will be able to reveal their experiences and practices in order to make change. They are very much aware that these whakapapa and life-stories will be challenged, called into question and others will debate their ideas and views. Subsequently, they view this as an opportunity to make change and make a difference in the lives of health professionals who care for Maaori who access these health settings. To enable this to occur, this research study is vital to the health and wellbeing of Maaori and the challenge is to do justice to the research study being proposed.

\section{The theory of Maaori as a people}

Because Maaori as a people have been dominated by ideas and values not of their worldview, they become mistrusting of the academic attempts to achieve this. Any exploration of Maaori mythology, tikanga and kaupapa, hapuu, iwi histories, kawa (protocol) and ideals which are captured, displayed, measured, dissected, distorted and torn apart, suggest that academic theory has not reflected meaningfully, concerning the ideas and views on tikanga and kaupapa related to Maaori.

Yet theory at its basic level means to make sense of reality. It enables us to make conjecture and theory about the world in which we live. Contained within it is a method of locating, positioning, legitimising and choosing what we do and see. Theory enables us to deal with doubts and differences. More significantly for Maaori, it gives us a space and voice to explain, prepare, strategise and manage our future, which then guarantees our survival as a people. The language of theory allows us a way of shaping and organising action. It allows us to understand and envisage consequences of what is being told about and to us. Theory can protect Maaori because it contains within it ways of putting certainty into perspective. If it is good theory it will allow the customary knowledge, original ways and ideas of looking at things to be integrated and undertaken without the need to search for a new theory. It contains within its contents mechanisms for change and 
outcomes. This research will achieve this, as the theorising journey has been undertaken by, for, with and about Maaori.

\section{The word Maaori means ordinary or normal}

The definition from Reeds Dictionary (1999) of the word Maaori literally means normal or ordinary. Whereas Cleve Barlow" ${ }^{31}$ (2003, p. 70) contends that "Maaori are the Indigenous people of this land" as they were here before the Paakehaa. Everything about our experiences as Maaori under a different culture has been about our differences regarding one's kawa, tikanga and kaupapa, and including the definition of the word Maaori. When defined from a Paakehaa perspective compared to the definition given by Cleve Barlow, the difference in the interpretation becomes clear. This is when difficulties become obvious around the worldview held by Maaori and the challenges begin. We observe this in what is termed normality within politics, education, social policies, health and economics, as it significantly contributes to the continued debate about intelligence and other means of determining what counts as normal in Aotearoa as a society. The impact of these views on Maaori identity has been powerful. The life-stories written about Maaori and Indigenous people's experiences, which outline these differences, are coming to the forefront in contemporary viewpoints. For example, Acoose, (2001), Akiwenzie-Damm, (2001), Attwood and Magowan, (2001), Beckett, (2001), Binney, (2005), hooks, (2000), and van Toorn, (2001) have written on this subject.

\section{Indigenous writers and researchers work}

The way in which Indigenous people base their experience of the world is motivated by wanting to disclose this knowledge, particularly from their worldview. It is holistic in nature, which aligns itself with that of a Maaori viewpoint. The means by which it is communicated, conveyed and transformed is through the oral and written expression that one's forebears left them. As such the works of Indigenous writers and researchers (for example Piquemal, 2001; Ten fingers, 2005; Tucker, 1977; Westerman, 2006 and, Young, 1998) play an important part in this study, because they validate and give creditability to many aspects that Maaori believe in. The challenge is to show the linkage these writings have to that of Maaori.

\footnotetext{
${ }^{31}$ Known as Cleve Barlow and of Ngaa Puhi iwi affiliation. Barlow has been educated within one of the last Whare Waananga from the north. He holds graduate qualifications from the University of Auckland.
} 


\section{The contribution of a Maaori transcriber}

Within the participant's profile the option is given to be able to converse in te reo Maaori and English while engaging in conversation regarding their whakapapa and life-stories as outlined in Chapters 4 and 5. To ensure that what is being conveyed in te reo Maaori and then transcribed, I needed to acquire a Maaori transcriber ${ }^{32}$ conversant and able to write in the language. Because of the concept of whanaungatanga this would be achieved. This enabled the participants to feel secure in the knowledge that the person transcribing was not a stranger to them, which allowed them to focus on their stories. The other concept to be introduced is that of kaitiakitanga. Through this concept the transcriber will ensure that the stories being transcribed will be respected and that the mana and mauri of the participant's including their whaanau, hapuu and iwi is acknowledged. Because the format of the ethics proposal is outlined from a Western viewpoint whereby the confidentiality form is structured from this perspective, this is where the challenge begins. By the introduction of whanaungatanga and kaitiakitanga would ensure that the transcriber (without having to sign) recognises and respects what is being implied. It then allows a Maaori world view to be positioned and acknowledged as part of the ethics requirement.

I identify as a Maaori woman, grandmother, mother, nurse, educator, researcher and student and firmly believe that this has relevance to the research study being undertaken. It does not mean that $I$ believe this gives me the right to assert or to extol the virtues of knowing everything there is to know about what it is to be Maaori. What I am saying is that it allows me to position myself within this study in a way that is important to those six Maaori participants who are part of this journey. It is who I am and who they are. The experiences to be disclosed within this worldview, and what we recognise as being normal given the social and historical aspects that have been written concerning Maaori, cannot be taken for granted. I need to make it clear that this does not mean that I think being Maaori means the same for me as it does for other Maaori.

First, Maaori people are diverse in character and ideas and that is simply how it has been. We recognise our differences from each other; it is embedded in our tikanga and kaupapa and our reo Maaori. Second, it does not mean that as Maaori we do not use or understand

\footnotetext{
${ }^{32}$ Known as Kahukura Kemp and of Ngaati Raukawa, Ngaati Toarangatira, Ngaati Huia and Ngaati Tuukorehe iwi affiliation. Kemp holds a qualification from Te Waananga o Raukawa and has an extensive background in transcribing.
} 
our differences as a strategic mechanism for asserting our claim to tino rangatiratanga ${ }^{33}$. Finally, it does not mean as Maaori we do not struggle constantly within the discussions and conversations we have; I attribute this to our differences. What I am saying is that as Maaori, we have human frailties like any other human being in this contemporary world.

\section{Structure of the study}

While on this journey of academic achievement, what became an obvious factor is the limitation of Paakehaa academics who use and understand Maaori words. This is treated like a foreign language particularly in the area of referencing whereby Latin words are always integrated into referencing styles. There has been a quiet and determined movement in academic writing by Maaori, since there are many Maaori words which are used in texts, without any distinction being made between Maaori and English. It is argued that both languages are our national language and should be accepted. Similarly, there should be less of a need to produce glossaries, which give dictionary meanings of Maaori words. I have not provided a glossary for this study. Within this study I have used Maaori words with the approximation of Paakehaa alongside to help the process as it has been indicated that those readers or examiners who have no understanding of Maaori will have difficulty understanding the contexts and content. It is then not unreasonable to ask that those academic readers and examiners, who have no insight into the Maaori language and its meanings, start the journey of discovery around this issue. We, as Maaori students undertaking this journey of study, have to be conversant in English and as well knowledgeable in all means of constructing studies of this dimension from a Western worldview.

From this disclosure I decided to revisit the issue that in this text I want to position the Maaori language by making distinct the wording between Maaori and English. This maybe viewed in many ways, but I have outlined the following reasons for why I believe this is important. First, it needs to be clear that Maaori words cannot simply be slotted into

\footnotetext{
${ }^{33}$ Cleve Barlow $(2003$, p.130) strongly contends that "tino rangatiratanga or rangatiratanga is not the word to describe the epitome of Maaori power and status. The word does not occur in the customary Whare Waananga of Ngaa Puhi. This is a new word coined by the Paakehaa when the Treaty of Waitangi was written and this land was colonised in 1840. But in recent times, some unschooled Maaori have widely adopted the term to epitomise their sovereign power and status. The correct word is arikitanga. This is the word that my tuupuna used to describe the concept of mana or power of the Maaori, as in the phrase 'te arikitanga o Ngaa Puhi'. The term tino rangatiratanga (a term coined by colonists who suppressed Maaori sovereignty) and we need to use instead the word arikitanga - a word coined centuries ago by Maaori to describe their supreme power and authority".
} 
the text. Maaori readers view Maaori words as having meanings attached to them, which connect the word itself to other situations, to knowledge and to a Maaori worldview. Second, some would say that Maaori words get appropriated once others learn how to use the word in one or two situations or contexts. Third, at a basic visual level, there are different textual viewpoints that Maaori words on their own differ from those of English terminology that are created. The existence of these different viewpoints is part of the discussion within this research study. I would like it to be noted that I use Maaori language because there is no alternative expression in English to express what it is I want to say. I have not used Maaori words merely to demonstrate I know them, but I have endeavoured to use both Maaori and English to convey meanings and context. Fourth, Maaori words have multiple meanings and interpretations and this affects the way in which the contexts and contents are viewed. For example, hapuu can mean sub-tribe or being pregnant. Finally, the use of double vowels will be used for Maaori names. Margaret Orbell (1998, p.34) says "double wording was part of kaumaatua (elders) understanding” regarding the Maaori language.

In addition, I have used italics, the font Times New Roman and bolding to add meaning to Maaori words, key phrases and to enhance a point of view within the text. The headings used are bolded only and use font size 14, Times New Roman. At times subheadings are bolded and font size 12, Times New Roman is used. Working titles, books and papers written are bolded and italics inclusive will be words that will be bolded only. I wanted to have a space to elaborate, add or to have another say in a way, which served a purpose to enhance this research study from a Maatauranga Maaori continuum. Footnoting has been used to make the process of understanding and interpretation of Maaori and English words more accessible. It has also allowed me to include aspects about those Maaori academics and non-academics, a space in which to personalise and acknowledge information about them that cannot easily be included in the body of the research study. In the end, I wanted to be able to produce a study that allows opportunity to comment, critique and to permit dialogue and freedom of thought. Artwork of a young Maaori woman artist namely, Chanel Raewyn Taiaroa $^{34}$ has provided sketches (Appendix 1) as visual aids for this

\footnotetext{
${ }^{34}$ Known as Chanel Raewyn Taiaroa of Ngaai Tahu, Ngaati Raukawa and Ngaati Kahungunu iwi affiliations. She holds graduate qualifications from the Fine Art School of Elam and Maaori Studies from the University of Auckland. Her work depicts themes around the creative stories particular on Papatuuaanuku from a contemporary viewpoint. She has great admiration for Pacific artwork and includes themes of this into her paintings and sketches.
} 
research study. Photography has also being provided. A map of Aotearoa is included to identify $i w i$ affiliation (Appendix 2).

Within this study there are six chapters. These chapters concentrate on key concepts regarding the research, through the inclusion of sections and sub-sections. It is mainly written in the past tense, except for the section involving the participant's life-stories in which their voices will be in the present tense. I have endeavoured to capture in this thesis and its contents a way in which to portray the backdrop of these whakapapa and life-stories that have been part of these participants and my own upbringing, while engaging in activities that contribute to what and how we are as Maaori. The stories and storytellers of these various periods captured the wairuatanga and experiences that brought these stories alive, even though they were stories of the past brought forward to reflect the present and future. While the voices of the participants are ever-present in this research study, I have included my own life-story accounts regarding my experiences of Maatauranga Maaori and its influences in nursing practice. To support this stance I have used the visual metaphor of likening this research journey to that of weaving a whakapapa panel, constructed from harakeke (flax) with its many strands, not yet completed but even with its basic structure, it is preparing to tell a story.

In Chapter 1, I provide an overview of the study and introduce key background material related to the focus and context of the research. It outlines my assumptions on the research questions, namely, What are Maaori registered nurses' understandings of Maatauranga Maaori in relationship to nursing practice? How do they apply these understandings in nursing practice? This goes someway to enable the reader to recognize my position on why I undertook this study and the challenges that come with such a stance.

Chapter 2, is organised into two sections. Section 1 presents an in-depth exploration on Maatauranga Maaori, those kaupapa associated with this worldview and what is embedded within this customary position. It is important to this study that both Maaori and Paakehaa health professionals undertake to understand this, because it allows an awareness of these kaupapa to be gained. It engages the reader with the epistemological position of Maatauranga Maaori. It will also enable the six Maaori registered nurses' whakapapa and life-stories to be positioned in a way that makes sense of their worldview. Because both the six participants and I are concerned with the contemporary understanding of 
Maatauranga Maaori and how it impacts on the care of Maaori, what will be written in this regard will be explored later in another section of this research study.

In chapter 2, section 2, I focus on the importance of the customary Whare Waananga and its relationship to the development and transmission of Maatauranga Maaori. One cannot gain understanding about Maatauranga Maaori without undertaking the journey of where this knowledge was situated, who were the transmitters of this knowledge and why they were positioned this way.

Chapter 3 is divided into two sections. Lather, (1991) states that we reside in an era that encourages nursing studies to explore different and innovative methods of theoretical and philosophical positions that inform our nursing research. Nurses and educators as researchers are encouraged to search and use different ways or possibilities of making sense of life and the stories they bring. In section one, I present a conceptual/theoretical framework to guide the methodology, method and design of this study that endeavours to do this, namely Maatauranga Maaori. As a kaupapa it is not new, but as an epistemological framework for research study it is new. With the pulling away of the many threads involved in this study I have concentrated on weaving the what and how questions, so that answers can be found by the use of the whakapapa and life-stories of these six participants. Storytelling and storytellers central to this study have been women who are Maaori registered nurses, who have contributed to the ongoing commitment to this mode of communication for Maaori, so the research method is focused on women and positioned from a Maatauranga Maaori continuum. It brings together the following themes; the role of the researcher from a Maatauranga Maaori continuum; life-stories as an inquiry; the researcher's personal view on storytelling; Charles Royal's view in regards to stories from a Maatauranga Maaori continuum; the usage of life-stories by Maaori nurses researchers; the doing (or ontological) and the knowing about (or epistemological position) from a Maaori nurse researcher's viewpoint; issues of methodological rigour; life-stories oral stories and their application to this research study; research design; seeking ethical approval and the selection of the participants.

Chapter 3, section 2, outlines the research processes and features sections on: the beginning of the pathway with the participants; use of conversations; the understanding of the word I and the space needed to conduct these conversations; weaving as a holistic metaphor and its 
application to this research study; whakapapa as a life-story backdrop; gathering the lifestories; analysing and interpreting the life-stories; writing the whakapapa story sections; the process or phase of creating the kaupapa themes; development of the kaupapa themes and, the reflection on rigour from a Maatauranga Maaori continuum.

While chapters 1, 2 and 3 address the more prescribed part of this thesis, chapters 4 and 5 explore and focus on the material gathered around the whakapapa and the life-stories of the six participants. It is within these two chapters that the voices of the participants come into being, and a key kaupapa - 'being Maaori' as expressed through the idea that 'who I am' and 'how I am' becomes evident. In Chapter 4, I present each of the participants in the research, all of whom are happy to be identified by their given names - Kim, Te Ata, Hineroa, Margaret, Ani and Aroha by way of whakapapa stories. These whakapapa stories are intended to capture the 'being Maaori' aspect of the participant's lives, from their conception, whaanau, hapuu and iwi linkage, and health events/reforms and people that have impacted on them, to their educational background, becoming a nurse and their worldview. I have chosen to position this research in a way that recognises the amount of literature that I was fortunate enough to gather from the participants, with the conversations being conducted over a period of twelve months (2005-2006). I have taken sections of these participant's lives, and positioned them in a way that reflects them as Maaori women and as nurses. These whakapapa stories contributed to the development of the kaupapa themes that will be presented in Chapter 5 .

Chapter 5 focuses on the kaupapa themes that have arisen from the life-stories that have been revealed in the conversations with the six participants. Substantial kaupapa surfaced from the 'what' and 'how' research questions being asked, such as the kaupapa theme 'being Maaori' is 'who I am' and 'how I am'. However, other kaupapa are interwoven with this theme and also give meaning to what these participants were expressing. Each participant contributed in a way that showed similarities but also distinct qualities in their relationship to their identity as Maaori registered nurses, their understanding of Maatauranga Maaori in relationship to nursing practice. Also, how do they apply these understandings in nursing practice? Other material (such as drawings, mihimihi, photographs and waiata) given to me by the participants will be used to illustrate the emerging kaupapa themes. In Chapter 1, the hui conducted at Ngaatokowaru marae by 
the hapuu, reinforced the views expressed by the six participants within their life-stories. It is also another means of ensuring the rigour outlined in Chapter 3 is maintained.

In Chapter 6 I present my concluding summary. I engage with and reflect on the positioning of this research and share some of the positive and not so positive aspirations and beliefs of the participants, as we take this pathway together. I then discuss some of the key kaupapa findings that are revealed in this research, particularly the emergence of Maatauranga Maaori as an epistemological framework, which allows the whakapapa and life-stories to be revealed. What then occurs is the bringing forth of the lived experiences of the participants in 'being Maaori', which merges with the kaupapa of 'who I am' and 'how I am' in Chapter 5. This then captures and shows the emergence of whakapapa, whanaungatanga, te reo Maaori, tuurangawaewae (home ground) wairuatanga, manaakitanga and rangatiratanga (leadership) as the kaupapa in which these participants practice from within their nursing. I will also present a section that gives an overview of conjecture that has resulted from this study. I conclude with thoughts around further research advancement.

The natural progression of this study is to explore the customary kaupapa of Maatauranga Maaori and the environment of the Whare Waananga in which this knowledge was housed and taught. To establish and answer these research questions, I will explore the knowledge associated with this worldview in the next chapter. 


\title{
Chapter 2 Maatauranga Maaori: Maaori knowledge
}

From the start it was clearly stated that Maatauranga Maaori was the pathway along which this research would progress. This chapter brings together the concepts involved with Maatauranga Maaori and its many complex ideas, which will be disclosed when reading this chapter. These ideas allow the health and wellbeing of Maaori to prevail, ensuring, as concepts, that they reflect the holistic view Maaori hold of the world. These concepts identify oral and written means as a ways of communicating. If we then consider the way in which Maaori view the world, a very broad understanding needs to be maintained so that the reader can develop a view on the way in which this is structured. Maaori Marsden (2003) contends:

\begin{abstract}
Culture may be defined simply as the way of life accepted and adopted by society ... In Maaori terms, then, culture is that complex, whole of beliefs/ attitudes/customs/knowledge acquired, transmitted, evolved by their society as guiding principles by which its members might respond to the needs and demands dictated by life and their environment
\end{abstract}

From this account Marsden is saying that Maaori have a fundamental idea of the world based on what has been accepted and adopted allowing a standard of behaviour to be recognised in their social structures (Knox, 2005). This behaviour was enhanced by the tikanga and kaupapa associated with Maaori society. These are protected by stories associated with those tuupuna who contributed to their health and wellbeing. Mention is also made of those mythological stories, $i w i$ histories and symbols associated with such mystical people, which earned them a place in Maaori storytelling. Whether it is from a Maaori viewpoint (Marsden, 2004), Indigenous aspect (His Horse is thunder and Gipp, 2003) or a Western perspective (J. Batten, 2005) every society has its examples and stories, which inform and encourage the highest ideals of belief and behaviour. Everything Maaori did had a purpose to ensure that the social behaviour of people was paramount and that the many concepts involved with Maatauranga Maaori would ensure this continued. It maintained the health and wellbeing of Maaori people. 
With the introduction in the eighteenth and nineteenth centuries of values and beliefs associated with a Western viewpoint, those belonging to Maaori during this era, were diminished. The social control structure they were embedded in was slowly eroded away, resulting in a loss of understanding regarding the customary application and what it meant. Maaori whether willingly or unwillingly, embraced these alternative values and beliefs. This lead to the demise of their understanding of the tikanga and kaupapa associated with their worldview, their language and the Whare Waananga, which had always ensured their health, and wellbeing was paramount. Being part of the twenty-first century, Maaori have an obligation to our tuupuna to recall and embed themselves in the customary understanding of Maatauranga Maaori, by aligning this with the contemporary viewpoint we now find ourselves situated in. This is necessary, due to the fact that it allows Maaori health and wellbeing to come from a wellness and healing perspective. At present it is illness driven, resulting in conflicting, and at times unsuitable, situations for health care provision to Maaori.

Because of this, the importance of Maatauranga Maaori (to this study) is based then on two premises. First, this concept is important for a person to gain insight into the research questions being asked, namely, What are Maaori registered nurses' understandings of Maatauranga Maaori in relationship to nursing practice? How do they apply these understandings in nursing practice? One needs to search the literature, both oral and written, that theorise this as a subject matter. When viewing this literature the absence of research around nursing practice was noticeable, particularly in relation to the six participants and their topic under discussion. The second premise is that being Maaori is who the six participants are and who I am as the researcher. Therefore, the natural progression when undertaking a research study of this dimension, includes the stories of these participants as well as my own stories as part of the research. It will be these whakapapa and life-stories that will provide a pathway to answer the research questions posed in this study.

To identify relevant literature and gain an understanding of the topic under exploration, I will divide this chapter into two sections. Within these sections will be numerous subsections. Several different threads will unravel from the exploration of these concepts and what will emerge needs to be part of this research study. If we take each individual thread of our whakapapa panel, which we need to start weaving, a story or series of stories will 
become obvious. The first thread will be the contribution of mythology, tikanga and kaupapa associated with our iwi histories. The second thread is the understanding connected to the mythological whakapapa our tuupuna believed in. The third will be the interlinking of the kete of knowledge. The final thread of this section will explore the two primary kaupapa, whakapapa and te reo Maaori. Out of this will come secondary concepts, which show the embedding of the knowledge in relationship to Maatauranga Maaori and to those whakapapa and life-stories belonging to the six participants, which will be captured in Chapters 4 and 5. The bringing together of all these threads will then produce a whakapapa panel that represents what being Maaori means. To achieve this the literature written by Maaori academic writers such as Cleve Barlow (2003), Mason Durie (2006), Maaori Marsden (1997), Hirini Meads (2003), Charles Royal (2004), Ranginui Walker (1996) and, Whatarangi Winiata (2005) to name but a few, will provide the foundational framework. In Chapter 1, the oral communication by those repositories of knowledge who attended the hui held at Ngaatokowaru marae will contribute to this source of information. There will be a small number of Paakehaa academic writers whose works will also be sourced within this research.

Section 2 will outline the importance of the customary Whare Waananga and its relationship to the development and transmission of Maatauranga Maaori.

\section{Section 1 The kaupapa embedded in Maatauranga Maaori}

Because I have been fortunate to attract six participants who are committed to the exploration of this research and the questions being asked, it seemed a natural assumption that because they are confident and comfortable with concepts that are embedded within their worldview, so would other health professionals be confident, especially in this contemporary period. The nursing curriculum undertaken to educate nurses on Kawa Whakaruruhau/Cultural Safety (Ramsden, 1992) has been seen as the pathway by which to achieve this undertaking. But in its content and with the many societal changes that have occurred the curriculum does not reflect Maatauranga Maaori and what is inherently associated with the concepts in this worldview. Kawa Whakaruruhau as a concept is inherent in Maatauranga Maaori. What is to be outlined impacts on this understanding. 
With these thoughts in mind and further conversations with the participants, particularly what has been uncovered in Chapters 4 and 5, it appears that there are a considerable number of health professionals, both Maaori and Paakehaa, who do not understand the connection between the mythology, tikanga, kaupapa and iwi histories in relation to being Maaori. All of which relate to Maatauranga Maaori. It is the key to be found in determining how our tuupuna viewed the world and their place within it. It also informs our present origins of ourselves and continues to shape our beliefs and practices (Mikaere, 2003) and makes us who we are as being Maaori. The positioning of this thought within this research emphasises that these questions needed to be explored and understood, so that all health professionals feel more confident in dealing with this subject when it arises in their everyday practice.

\section{Mythology, tikanga, kaupapa and iwi histories}

Recreating and weaving the thread of mythology, tikanga, kaupapa and iwi histories is at times laden with complexities. The immense amount of both oral and written material have a variety of interpretations of these accounts by both Paakehaa and Maaori (Te Awekotuku, 1991). Nevertheless, it is important that this is undertaken, so that a rebuilding of these available sources is located from a continuum and positioning that is both informative and constructive to this study, particularly for the six participants and the conversations they are conveying.

To then ask the question what is mythology is easy; to ask what it is not, is the more difficult. Mythology is not a lie, nor is it an imaginary tale. Maaori Marsden (2004, p.177) contends that: "myths are neither fables nor fireside stories" but are "integral part of the body of knowledge" for Maaori. Whakapapa has embedded within it ideas and beliefs outlining the sequence of mythology, tikanga, kaupapa and iwi histories. Ranginui Walker (1992, p. 10) expands further on this idea by saying "for Maaori, the creation of myths is part of their norms and ideals". It is part of their everyday existence.

Maaori trace the birth of human beings from the creation of the universe to the conception of the first woman, thereafter including the expansion of culture and human society. It is an example of evolutionary expansion (Irwin, 1984) followed by a pattern of fertilisation (Marsden, 1997). The interpretation of mythology should involve an awareness of the value of relationships between the parts of the universe, rather than informal relationships; 
a concern in what matters rather than what happens (Patterson, 1992, p.156). Riddell (2001, p.132) continues to expand this notion by saying "having studied other cultures" we all have similar stories about creation.

Part of this understanding is that throughout history there are also interpretations, which differ from each $i w i$ in regards to mythology. Charles Royal (1998a) explains that Ngaa $P u h i^{35}$ had their own interpretation of the beginning of the universe. As indicated by one of the participants, their $i w i$ history indicates differences in their interpretation of how the world was formed compared to other $i w i$, but this difference has been an accepted factor of life. Similarly, the understanding of Ngaai Tahu ${ }^{36}$ regarding mythology of the South Island is dissimilar to those of other iwi affiliation (King, 1997). All adding to the analysis and interpretation of mythology by those associated with their $i w i$.

There are those earliest Paakehaa thesis writers such as Jack Tizard (1940) whose accounts of mythology, of Maaori have been contentious to others of Western beliefs. Tizard (1940, p.23) states Maaori knowledge comprises of myths, magic and superstition and he goes further to say that "myths are conflicting and in many cases puerile". Sigmund Freud (1953) contends that it may perhaps seem as through our theories are a kind of mythology ... but does not every science comes in the end to a kind of mythology like this.

At times throughout our professional careers as Maaori nurses, we have had exposure to this type of conversation with those who identify as Maaori. To hear such ideas and beliefs expressed around myths could be misinterpreted and misunderstood by those not of this worldview, and could result in the person being psychologically assessed, instead of being treated for the physical problem they had been admitted for. It is on this basis that I have included discussion of this subject, and how important it is for health professionals to gain insight into this knowledge.

\section{Mythological whakapapa}

The next thread to be considered is the kaupapa embedded in the belief and value of mythological whakapapa. Maaori philosophers of that time determined that the creation

\footnotetext{
${ }^{35} \mathrm{Ngaa}$ Puhi is the iwi associated with the North Island and can be located on (Appendix 2) number 3.

${ }^{36}$ Ngaai Tahu is the iwi associated with the South Island and can be located on (Appendix 2) number 31 and 32.
} 
of the universe was divided into three periods. The first period, being Te Kore, the immense emptiness of space. The second was Te Poo, the internal darkness of space. The third period was that of Te Ao Maarama, the world of light, in which humans live. The first two periods are timeless, and when the seeds of the universe were scattered throughout space they came together to form earth and sky (Simmons, 1976). Hinureina Managan (2003, p.4) states that "Te Kore is the most remote stage:" a period in which there was nothing and the world was void. Figure 1 is what Chanel Raewyn Taiaroa as a contemporary young Maaori woman artist feels that the void of Te Kore means for her.

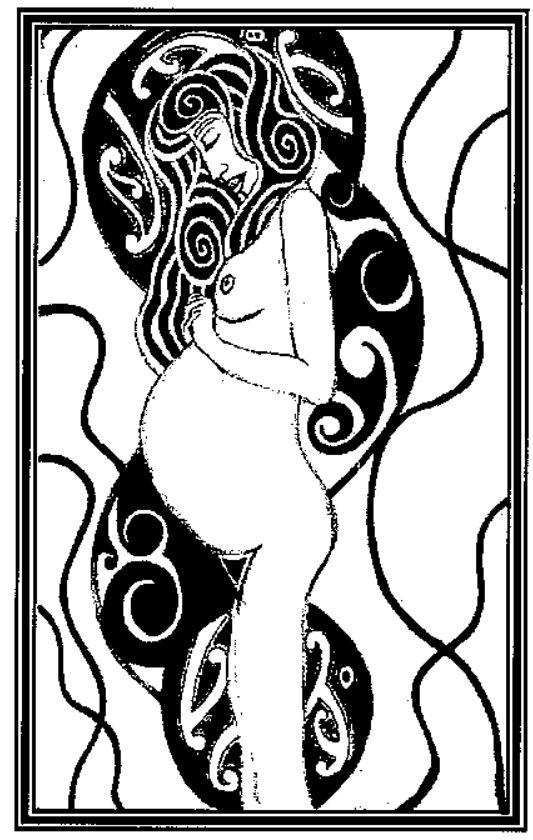

Figure 1: Te Kore represented within mythology (Sketch by Chanel Raewyn Taiaroa)

The customary belief of Maaori is that the whole of the universe is a dynamic movement from one state to another, Te Kore, Te Poo and Te Ao Maarama. Vital to this notion is that movement through each period is not motionless, but rather one of continuous interaction and revisiting (Managan, 2003).

One can understand why people whose beliefs, values and worldview do not include mythology would consider this unimportant. It lays open questions around its credibility or validity to be included in any research study, but what is obvious is that it is part of Maaori (Walker, 1996) and Indigenous people's (Battiste, 2000) way of life and being. This includes people with Western beliefs who support and believe in mythology themselves (Batten, 2005). The value placed on its holistic nature and the contribution it 
makes to the survival of people as Maaori then makes it a subject that needs to be included in studies of this dimension.

In understanding the many mythology stories, there are those Maaori who have a different description of these periods. But no matter how varied they are, two names are acknowledged in mythology, namely Papatuuaanuku (earth mother) and Ranginui (earth father). Ranginui had been joined in an affectionate and caring embrace with Papatuuaanuku and because of this, the world was in continuous darkness (Figure 2).

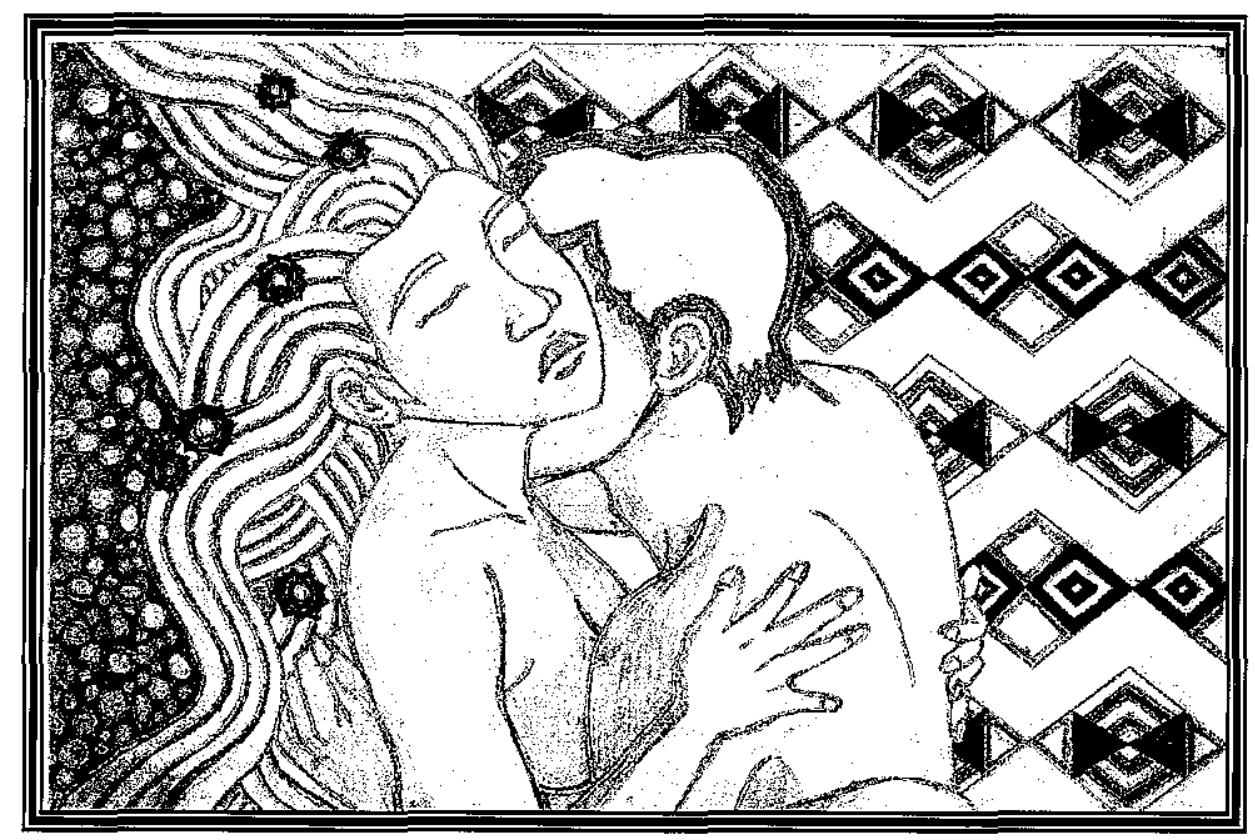

Figure 2: Papatuuaanuku and Ranginui embracing (Sketch by Chanel Raewyn Taiaroa)

Papatuuaanuku nudity was enclosed with vegetation, which flourished in these damp surroundings. Those children produced, especially their sons, continuously complained about the wretched conditions in which they were confined and as time progressed they finally decided to rectify their situation.

Tumatauenga (God of war) suggested that their parents should be killed to enable separation to occur. Taanemahuta (God of the forest) and later father of mankind, protested against any such action as he felt it would be sufficient that their parents be prised apart, allowing the sky to be above and the earth to lie below. He believed that the earth should remain their nurturing mother, but the sky would become a stranger to them (King, 2003). This creative demonstration of thinking was built into Maaori thought and the event is marked by the name Taane te too ko te rangi. As a metaphor it encapsulates the 
image of Taanemahuta, supporting the heaven with his legs and pushing the sky away from the earth, resulting in the mythology and name associated with this being embedded in the landscape. Its genuineness is evident in the experiences of those who enter the forest. Through the overhead green canopy of the mighty kauri and tootara trees one can visualise the props used by Taanemahuta to support the sky (Meads, 2003).

Each of Papatuuaanuku and Ranginui children with the exception of one son, Tawhiri matea (God of the elements), took turns to separate their parents. When Taanemahuta placed his shoulders against the earth and his feet upon the sky, and straightened his body, his parents were torn apart. As soon as this occurred, the children of Papatuuaanuku and Ranginui knew light for the first time. The children of Taanemahuta - the birds, insects and trees of the forest were able to see, move and breathe (Best, 1924).

The suffering inflicted on his parents, and the fact that other living things acknowledged and held Taanemahuta in high regard, angered his brother Tawhirimatea, who not only objected to the separation of their parents, but also to the way in which Taanemahuta was now being regarded. He followed Ranginui to the sky above and produced his own offspring, namely storms, wind and rain and these children in turn were unleashed on the offspring of Taanemahuta in retaliation for the unspeakable deeds committed. From the skies above he hurled himself as a hurricane and uprooted Taanemahuta trees. After wrecking havoc on all his brothers, Tawhirimatea returned to the sky, where from time to time he and his children would remind those on earth they were still a presence to be aware of (Buck, 1958).

So intense was their parent's grief at being parted, they wept ceaselessly. Papatuuaanuku tears produced mist which froze on her body as frost while Ranginui poured down hail, snow and rain. After observing this, their children were determined to turn Papatuuaanuku over onto her face so that she and Ranginui could no longer witness one another's pain. This resulted in Papatuuaanuku instead looking upon Te Poo, the place where those who have died and their spirits descend to. Even under those adverse circumstances, Papatuuaanuku was protective of her children. According to Best (1924, p.29), Papatuuaanuku said "I brought them into this world, leave them with me to deal with". 
Another mythological figure that is renowned in our stories is that of Maaui. As a child he was known as being nanakia (untrustworthy) and as Hanson (1982, p.335) states "Maaui challenged and probed behind questions never asked". And like many youngest-born, Maaui was gifted and overindulged, especially by his grandmother. When Maaui needed or wanted advice it was his grandmother that he sought guidance from. According to his whakapapa he was a teina and was of low ranking, but Maaui compensated this by being more astute and accomplished than his brothers.

Maaui has been acknowledged as the person who fished up the North Island of Aotearoa. In fishing stories (and there are numerous accounts) Maaui stowed away on board his brother's waka (canoe) in Hawaiiki, ${ }^{37}$ the customary Polynesian homeland. His brothers were infuriated by his shrewdness and wanted to return to shore but they were too far from land so they continued with their fishing expedition. After filling their waka with catch, Maaui proceeded to create his own hook, the barb of which has been shaped from his grandmother's jawbone. When the brothers found out, they refused him bait so Maaui struck his own nose and smeared the hook with his blood. On lowering his line he immediately hooked a fish of unbelievable size, and the only way he could recover the fish was by narrating a chant to make the weight of the fish lighter (King, 1997).

When the fish was pulled to the surface Maaui left the waka to find a priest who could make an offering to the Gods and perform the correct ceremony, but before doing so he warned his brothers not to touch this mighty fish until this ceremony was performed. However, his brothers ignored this advice and they leapt from the waka and began scaling the fish. They proceeded to hack bits off, while at the same time the fish raised its fins in anguish and distress. The sun rose and made the flesh solid underfoot; its surface became mountainous and rough because of the havoc wrought by the brothers. It remains that way, and the name given to it Te Ika-a-Maaui, the fish of Maaui (King, 2001).

The ability of Maaori to understand the mythology, tikanga, kaupapa and iwi histories was recreated by the use of symbols and imagery. It allowed the world to be created in a way that reflected images, which depicted, illustrated and represented some perceived reality

\footnotetext{
${ }^{37}$ Hawaiiki is the name of the ancestral homeland of the Maaori people. Most Maaori tend to agree that there are many Hawaiiki, and that the name may in fact be of a symbolic nature, i.e. the name of the last departure point.
} 
within their minds. This occurred in the form of myths, which was then recreated in the human mind in the form of maps, models and paradigms through which one's mind can grasp, reconcile and understand the real world behind that (Marsden, 2003), It then allowed Maaori to understand their worldview in a way that made sense to them. These thoughts have also been endorsed by Indigenous writers in regards to the value of mythology as part of their worldview (for example Battiste, 2000; Sakej, 2000; Yazzie; 2000). These writers also identify the value for Indigenous people of creating mind maps with which to remember details of their histories given to them by their old people (Cajete, 2000).

\section{Kete of knowledge}

As a thread to unravel, the importance of the kete of knowledge and its significance to Maaori is its relationship to how it is positioned within a Maaori worldview. Cleve Barlow (2003) explains Taanenuiarangi, ${ }^{38}$ descended to the twelfth heaven (some versions indicate this as the seventh heaven) to gain knowledge and while there he acquired the kete of knowledge and the mauri of the Whare Waananga, which residues in two stones. These stones were known as, te hukatai and te rehutai (Buck, 1949; Smith, 1913), and as gifts these were essential to the continued existence of Maaori as a people.

This was received from $I o^{39}$ the supreme being of Maaori customs. Once Taaneuniarangi had descended to the twelfth heaven known as Te Rangi Tamaku, he created the first Whare Waananga of Maaori customs, called Rangiaatea. Rangiaatea was the name of the house that $I o$ and Taaneuniarangi entered, and was the repository of the kete of knowledge and the mauri of the Whare Waananga. According to Ramsden (1951, p.89) "Rangiaatea is the place where people worship" and it was in this place that they "paid homage to Io, the supreme God in Hawaiiki nui ${ }^{40}$, Hawaiiki Roa. Hawaiiki Pamamao, the land from which Maaori came".

\footnotetext{
${ }^{38}$ When the children of Papatuuaanuku and Ranginui entered the world of light and dwelt with Papatuuaanuku, they became iri tangata (mortal beings). Being under the control of the physical world, they became subject to illness and death. Taaneuniarangi was the first man to inhabit this world and he married Hineahuone (the first woman).

${ }^{39} I o$ is the supreme god, but the customs concerning Io were collected very late (in the 20th century) and must be considered in that light. Revelations of the name and attributions of Io were first made by the Wairarapa tohunga (expert) Te Matorohanga and published in 1913.

${ }^{40}$ Hawaiiki-nui or Hawaiiki-rangi was sometimes said to be huge whare or temple on a mountain in the Hawaiiki homeland. It was a way station along the journey for the spirits of the dead.
} 
Consequently, the features of the pre-Christian Rangiaatea are interlinked with one another. Io, as the originator of knowledge, distributes this knowledge to Taaneuniarangi, who then creates a Whare Waananga as a storehouse of that knowledge. Rangiaatea is the name of this Whare Waananga, and central to Rangiaatea is the tuuaaha (alter) upon which the representational aspects of the Whare Waananga are held. Within the tuuaaha is the mauri, which is a means by which the relationship with Io is upheld (Royal, 1997a). The knowledge Taaneuniarangi gained was separated into three baskets and then it was spread amongst the people. The kete were limited to three different types of knowledge: the kete uruuru matua (peace and goodness), kete uruuru rangi (prayer and incantations) and kete uruuru tau or tawhite (war, agriculture, woodwork).

Cleve Barlow (2003) says that, the difference between the kete uruuru tau or tawhiti and the other two, is that man can obtain worldly knowledge for good or evil reasons according to his intentions, whereas the other kete is committed specifically to evil intent. As an example, it is possible to use nuclear energy to activate equipment, to carry water to dry lands where food can be developed to feed the masses but it is also possible to build nuclear weapons for the destruction of mankind. Even though it is the same source of energy, one intent is based on caring and the other is based on destructiveness.

To understand what being Maaori means involves linking and weaving together mythology, tikanga, kaupapa and iwi histories and their complexities, as well as, mythological whakapapa and the value of the kete of knowledge. All of these aspects form the basis by which we then as Maaori focus on the blueprint of whakapapa as the blood link that connects us as a people. From this unfolds other concepts that become important for the reader to gain an insight into how and why we view the world the way that we do. It also reinforces the conversations had with the six participants that have been recorded in Chapters 4 and 5.

\section{Whakapapa}

The next aspect to consider is whakapapa, which is that of the genetic blueprint it contains and how this thread is woven through everything Maaori perceive in life. To Maaori, whakapapa is central to how they view and interpret the world. Cleve Barlow (2003) states whakapapa means to lay one thing upon another - that is, to lie one generation upon 
another and it becomes the fundamental building block on which Maaori understand who they are.

The academic work undertaken by Ranginui Walker $(1999$, p. 6) A paradigm of the Maaori view of reality, states that "the worldview of Maaori is encapsulated in whakapapa". This then becomes essential to Maaori identity. Joe Te Rito, a Maaori academic used whakapapa as the framework for his doctorial thesis Te Tiihoka me te karo: Struggle and transformation of Ngaati Hinemanu of Oomaahu (Te Rito, 2007). Te Rito's writing identified whakapapa as the fundamental key to unlocking the answers needed to ensure the survival of his whaanau, hapuu and iwi.

A person when born, is given at birth a primary gift and personal characteristics. To Maaori this is known as whakapapa, which according to a Paakehaa viewpoint is the common element of one's ira (genes) or deoxyribonucleic acid (DNA). Accordingly, Maaori contend that every person is a recipient of two whakapapa lines when born from the mother and father. However, it is possible within this contemporary period, that a person may be born into a one-parent whaanau. This allows a person to identify a place within the hapuu of that whaanau enabling a person to identify their whakapapa within their $i$ iw. This sequence allows whanaungatanga to develop, and a person can then say I am Maaori, irrespective of one or two parent relationships (Meads, 2003). Maaori are born into whanaungatanga connections, which were previously in place, and have been for many generations. This then allows the person to say - for example, in my particular case as the writer of this study - I am the descendent of Ngaati Raukawa ${ }^{41}$. The name of the founder of the hapuu or iwi, which one belongs to as in the writer's case, is preceded by the prefix Ngaati (meaning descendent of) and determines their identity. It anchors the birthright and locality to those tuupuna, gives value to a person's identity and endorses this understanding. $\quad$ Rose Pere $(1982$, p.7) contends, "it is your whakapapa that makes you what you are".

Included is my whakapapa (Figure 3) as an example of those tuupuna who have gone before and who hold the continuation of the line. It anchors my birthright and locality to these tuupuna and gives value to my identity. To find the worldview of Maaori culture,

\footnotetext{
${ }^{41}$ Ngaati Raukawa is an iwi which can be located on (Appendix 2) numbers 11 and 28.
} 
one needs to, I believe, commence with the practical experience of reading and thinking about one's whakapapa. I have traced my own whakapapa back through the ages, through generations and back to those tuupuna now gone. If people can subjectively, passionately and intuitively connect with the inward reality, which the outward symbol seeks to suggest, then one has understood the Maaori worldview. This process commences with understanding one's whakapapa (Marsden, 1997).

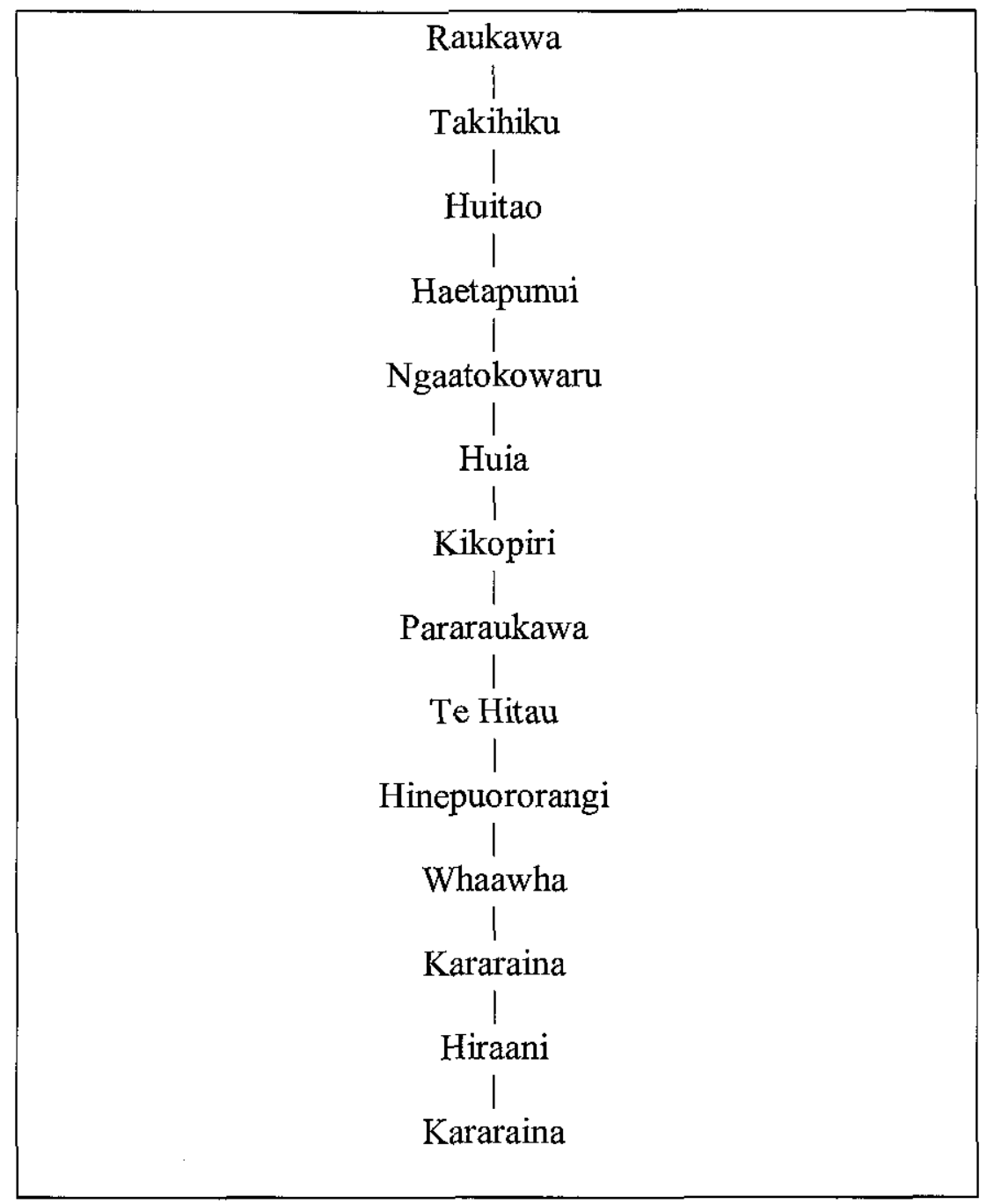

Figure 3: Researcher's whakapapa

Everything we do as Maaori is from a holistic viewpoint, and when the whakapapa and life-stories of these six participants are conveyed it will indicate concepts that have influenced their lives and those of their whaanau, hapuu and iwi. All of these elements interlink into the concept of being Maaori and reflect the who, what, why and how questions that impact on Maaori as a people, and it will endorse the stance that these six participants have revealed in Chapters 4 and 5. 


\section{Tuurangawaewae}

The significance of tuurangawaewae is that it is a key to a person's birthright in regards to their locality. Being born to one or two Maaori parents allows "the right of a person to a place for their feet to stand - that is tuurangawaewae" (Meads, 2003, p.65). By right of birth it is a place where one belongs. It represents one's locality, one's spot on this earth whereby an individual can say I belong here and I am able to stand here without being challenged because my tuupuna now gone allowed a person to stand tall here. This place includes a person's hapuu and iwi and the rights of whenua (land) interests, and it is full of the history of one's tuupuna. This provides the whanaungatanga link between a person and their whenua allowing the establishment of tuurangawaewae. It establishes the foundation and beginnings of a person's whakapapa, sometimes referred as one's roots or place of belonging, for example, one's whaanau, hapuu and $i w i$ histories and ambitions (Ka'ai and Higgins, 2004).

\section{Whaanau}

As Maaori we identify whaanau as the basic building block of our whole social system. According to Mason Durie (2003a) whaanau means to give birth, whereas the Williams Dictionary (1971) defines it as offspring and to be born. Both small household units and those with large extended groups numbering several thousands members identify as whaanau, but a key characteristic, is that its members are born into it and all are related by their whakapapa connections. The term used to characterise this group of people contains distinguishable qualities compared to some other groups of people. The whaanau philosophy, which is described by Paakehaa anthropologists as the kinship system, and by Maaori as the kaupapa of whakapapa, underpins the whole social system. That is, one must be born into the fundamental building block of the system in order to be a member as of right.

The customary whaanau operated as a unit for ordinary economic and social affairs and were housed in either one single dwelling or several houses, within a village. Under the person appointed as the head of the group, members undertook several important tasks, such as fishing, building waka, bird hunting, rat trapping and digging kuumara (sweet potato) plots. Each whaanau was self-reliant and as a rule, managed their own affairs without intrusion from others, except in such cases when it impacted on the whole village. 
In regards to the size of the whaanau as a unit, this is of great importance, as it allowed the kaupapa of kootahitanga and close interaction to be nurtured. It would consist of three generations, such as grandparent, parents, their siblings and grandchildren, and numbers could vary from a small unit up to one hundred whaanau members. A whaanau containing a small group could consist of the siblings of one parent, uncles and aunties and some grandparents. But when these uncles and aunts married, and had children, they remained as part of this unit, therefore the numbers could increase, significantly. It was then possible for the whaanau to have several nuclear whaanau within it (Firth, 1959). The main purpose of the whaanau was the reproduction and fostering of children. Children were more influenced by their grandparents and kaumaatua in their upbringing, when in the event of the death of the parents this was not such a traumatic occasion because of this type of nurturing. The whaanau also cared for their tuupuna who were elderly and aged. These people were revered for their knowledge and wisdom and valued for their contribution towards minding the young and performing tasks useful to the livelihood of the group (Best, 1974).

\section{Hapuu}

A hapuu is the basic political unit within Maaori society (Schwimmer, 1966). In customary times it occupied an area of land, and controlled resources such as specific fishing grounds, mahinga kai (seafood and other sources of food) forest and wetlands. The hapuu had a rangatira (chief) as their leader or ariki (high chief) and their primary role was to ensure the group survived, and its land resources were defended and protected. The hapuu were therefore responsible for their own defence and could enter into an alliance with other hapuu to protect its resources, integrity and people. This resulted in alliances being established, which enabled hapuu to be protected when invading forces decided to attack them.

The main feature of a hapuu is that it generally consists of more than one whaanau unit, and within it are strong whakapapa and whanaungatanga ties. The establishment of a marae, or the intention to do so, is a promotion of a hapuu. Well-established hapuu have at least one marae, which is managed over a long period of time. For some, this can be over a period of a hundred years, but this can vary for others. The wharenui (meeting house) is the focus for all its members and is where important decisions are made by the hapuu. It is characteristically named after a tuupuna, as well as the long association of the 
many members, from past generations, who have played their part in maintaining the hapuu. Large hapuu may have more than one marae and more often than not, members are able to trace their whakapapa back to the common tuupuna of that hapuu. For example, in the writer's whakapapa, the named tuupuna of the hapuu is Pareraukawa, so members would link back to her.

Fishing ventures were undertaken by calling on the labour of the hapuu. A well-organised and large hapuu was an effective social, economic and political force. It would be incorrect to think that a hapuu was like an autonomous state that stood alone against all odds. Hapuu did not stand alone nor did they exist in seclusion. The survival of each hapuu depended on coalitions, and on other kin-related groups. Therefore, members were definitely part of a larger group. The effectiveness of this was more apparent when marriages occurred between two rangatira lines, which bound those two hapuu through the consecration of marriage and the producing of children.

The decision-making was done by the rangatira or kaumaatua of the whaanau belonging to the hapuu. The responsibility of the rangatira was to listen to the opinions of the kaumaatua and others, consider the important points and then at the very end of the discussion, summarise and make a collective decision. The word of the leader then became the policy with which to uphold decision-making. As stated by Schwimmer (1966) the hapuu can act as an autonomous body and have a large control over the everyday affairs, but it could not stand alone in a social or military sense.

\section{Iwi}

The significance of the $i w i$ is it was the largest building block for Maaori and the principal political unit. According to Cleve Barlow (2003), iwi means tribe or bone. Throughout time the association with bone has not changed. This is important in relation to the metaphors for whaanau (birth) and hapuu (pregnancy), hence the related metaphor for $i w i$ is bone. Relatives are often heard to describe each other as bones and in this sense, members of an $i w i$ were bones which highlighted the importance of shared whakapapa. Another important aspect of bone as a metaphor is that it provides strength. Iwikore (no bones) means feeble and without strength. Bones make a body strong and give it form. Thus in the context of whakapapa, bones give it strength and the metaphor is important in understanding the kaupapa of iwi (Meads, 2003). The important aspect of this as a 
kaupapa is its function as a metaphor to whanaungatanga and the strength that arises from this fact.

The $i w i$ is larger than a hapuu, richer in resources far more numerous and occupies a larger area of land. The characteristics of an iwi are that it embraces hapuu who have large numbers and are descendents of tuupuna. The meaning of the word hapuu emphasises the whanaungatanga viewpoint, which signifies the criteria of belonging. Those individuals fulfilling ceremonial roles tended to be those who have clear rights of membership, and the more important the hui the more this kaupapa was applied.

The quality of one's whakapapa is also taken into consideration. For example, one might be a tuakana or one might be a teina or a person may have direct lineage down the aho ariki (chieftain line). Membership can be to the whakapapa of either one or two parents, but preference is for membership to a senior male line, or an ariki line. Whakapapa as a birthright is an important obligation because being born into the $i$ wi enables a person to establish their identity with this iwi (Meads, 2003).

\section{Marae}

The marae is a centre, which acts as a focus for the communal life of whaanau, hapuu and iwi (Salmond, 1976). This shared environment, becomes the focal point for ceremonies, which enables Maaori as a people to gather and practice customary tikanga. In customary times, the marae was selected as the open area of land straight in front of the sanctified wharenui and was known as the marae aatea (ceremonial courtyard). As a kaupapa, a marae was recognised and acknowledged as a very old part of the legacy of Maaori. Prior to the introduction of the word marae, Maaori used the word paa to describe such an area. When defining the word, the Williams Dictionary (1971) describes paa as a stockade or fortified place. As time has passed the reference to paa has declined and has been replaced by the word marae.

Each marae will have a name of its own, but it could also be named after its wharenui or its locality. The naming is very important - it is a uniting force and most people associated with the marae can trace their whakapapa line to their tuupuna (in the mihimihi of the participants they refer to their marae in some way). This then becomes their tuupuna, their wharenui, and their whenua. Each marae is an individual unit. Usually the marae has 
historical and customary importance. Many are as recent as the wharenui still standing on them, perhaps one hundred years old at the outside. This could be due to the fact that marae, as Maaori knew them, have developed since Paakehaa contact, and original settlement patterns have altered dramatically in this period. This has changed what this area was initially intended to be used for. Soon after contact with Paakehaa, economic patterns changed. This caused whole Maaori populations to shift from their growth and development as a collective, to focusing on work in timber stands, gumfields and flax swamps. The marae was superseded, and mission stations and ports provided a new area for Maaori to settle. The years of change and relocation of Maaori as a people have seen old marae shifted or abandoned, and new ones built (Salmond, 2004) to suit the situation that Maaori found themselves in.

In most rural areas today, the marae are set in farmland and separated from the surrounding land only by wire and post fences. The boundary fence that marks the marae has at least two gateways. One is usually located towards the rear of the marae for locals to enter through, and the second entranceway is for more ceremonious occasion and visiting groups. The marae thus has a physical boundary but it is also culturally protected. As, Salmond (2004, p. 34) says, "the marae in Aotearoa is a Maaori public place, and perhaps it is the last of these". It is within these surroundings that Maaori culture is maintained. The distinctive architecture, and whakairo allow the marae to be visually marked as Maaori, and its tikanga, kaupapa and the use of te reo Maaori also, distinguishes it.

The most noted feature of a marae is the layout, which allows for change. The layout is based on a fundamental, separation between the wharenui and the areas set aside for the wharekai (dining room) toiletry areas, shelter for the visitors at the entrance way and sometimes a whare mate (place for the dead to lie in state) (Meads, 2003). Another important area, is that of the urupaa. In some areas these are near the marae but in other areas can be situated some distance away.

\section{Whanaungatanga}

The significance of whanaungatanga for Maaori is that it deals with the practices that bonds and strengthens the kinship ties of a whaanau (Pere, 1982). Whereas Barlow (2003) indicates that whanaungatanga means relationships and is based on the principles of both sexes and all generations sustaining and functioning alongside each other (Pere, 1984). 
The basic unit of kinship is the whaanau. As a result, Maaori view the place of whaanau as being part of a collective, and the kaupapa of whanaungatanga is an important concept of inclusion and building relationships. Hence, whanaungatanga is based on tuupuna who's historical, customary, collective, and wairuatanga ties are acknowledged. It forms the strong bonds that influence the way one lives and reacts to his or her kinship groups, to people in general, and the way in which we view the world as Maaori (Pere, 1997).

I would like to note the contribution of articles written by Charles Royal (1997b and c) to this section of this study. In this section, whaanau is extended by a suffix to be whanaunga, which means relation. A characteristic use of the word whanaunga is to describe relations of one's family. Whanaunga are those of the same hapuu or iwi. However, if we again consider the broad context of the whakapapa of Te Ao Maarama, we see that whanaunga is not only about human relations (although this is important) but whanaunga is also used in relation to things of the world. Birds are the whanaunga of the rocks and so on, as indicated earlier in section on whakapapa.

Whanaungatanga, may also be interpreted as the art of relationships and their management, and again can be related to its context within whakapapa of Te Ao Maarama as a whole. Certainly, the preservation of relationships at a human level is serious, and the length of time over which our old people have preserved their knowledge of human whakapapa is evidence of this. However, whanaungatanga is also about the relationships linking all things. One's action in one's locality might be seen to have consequences. The use of the word karma/fate/destiny is accepted as it describes something, which we instinctively understand. Doing a bad thing in one's place - might have consequences elsewhere. The phrase what goes around, comes around also captures this thought. The world, therefore, is interconnected in some way and life is about understanding these relationships.

\section{Manaakitanga}

There are two premises we will explore regarding manaakitanga. First is the kaupapa associated with an important activity for the whaanau, hapuu and iwi when involving welcoming and caring for visitors who maybe at a marae for such an event. The hosting of manuhiri (visitors), sometimes for days or weeks, required a rigorous, communal effort. Every member of the tangata whenua (people of the land) had a responsibility, and everyone understood the significance of providing the highest standard of hospitality 
possible, because the mana of the whaanau, hapuu and iwi depended upon it. The organisation of a successful hui, then as now, had two major methods. The first involved activities out the back, which included arranging and gathering food, lighting fires, clearing away rubbish, washing dishes and ensuring that the visitors physical wants are met. The second method involved activities out the front: ensuring that the ceremonial requirements were fulfilled, that visitors were able to converse on the matters they had come to focus on, and that they were entertained (Mikaere, 1995). Some of the responsibilities regarding the hui and the application of manaakitanga were allocated according to gender, some according to age. As a general rule, it was the kaumaatua who saw to it that the ceremonial requirements were adhered to, and that all went smoothly out the front. Younger people were likely to serve their apprenticeship out the back, although those who showed potential could in due time work their way into a position at the front (Rangihau, 1992). Both genders played their part in both areas. At the back, both sexes contributed to most activities and worked in conjunction with each other. At the front, the roles tended to be more clearly defined, although it is suggested that there also existed a degree of flexibility in these roles.

The second premise is based on the contribution to this topic by Charles Royal (1997c). His interpretation of manaakitanga is viewed as containing two words, these being mana and aki (ascend). A lot can be said about mana, as it is one of those deep Maaori concepts that cannot be easily distorted into the English language. The two English language words to be used in association with mana are authority and responsibility. Although these two words do not stand for mana in their entirety, they do give us some positive direction. Those who possess mana exercise a certain kind of authority. For example, an individual who bears the mana of a particular atua possess the authority of that atua. Equally, if a person or community possesses the mana of a particular mana whenua (geographic area) they possess the authority for that geographic area. A particularly important aspect of authority is responsibility hence to engage with someone with authority would not be appropriate without some kind of responsibility. A person who possesses the authority of a particular atua has a responsibility to maintain a relationship to that atua and be responsible for the mana of that atua. In the same way, a person or community who possesses the authority of a rohe/takiwaa (particular geographic area) bears a responsibility to that geographic area. 
Power has been a term associated and approximated with mana, but a person needs to be cautioned concerning the use of the term power to signify mana. Whilst the concept of power can help to understand mana to a certain degree, there have been times when some Maaori (Charles Royal includes himself in this) have mistaken a power pathway for a mana pathway. This often occurs when young Maaori men who are just beginning to learn about their tuupuna, imitate themselves on the lives and careers of famous warrior male ancestors. They hear about their heroic actions and daring exploits. They learn about the power of warrior tuupuna like Te Rauparaha or Te Wherowhero and make the natural and seductive link between this historical power and their own contemporary power, or lack of it. Many young Maaori men believe that in order to become like their warrior ancestors, they too must possess power and must become powerful, because those tuupuna are seen to have possessed power. But power maybe dangerous. There are times when the outward expression of mana and power may appear similar. A nineteenth century chief like Te Rauparaha, who had the ability to oversee a large number of people, may be said to have both power and mana. However, it must be viewed in the context implied that mana and power come from different parts of the human core. Power often becomes evident as the expression of ego, and our own needs and requirements, and our own self-opinionated perception of the world. Mana on the other hand, occurs from a spiritual base, what is called Te taha wairua.

Aki means to ascend or elevate as in the karakia that says Whakatauria a Taawhaki ki te rangi tuatahi, akina ki te rangi tuarua (Taawhaki arrives to the first heaven and then ascends to the second). Therefore, the word manaaki, which consists of both mana and aki, means to elevate or raise mana. Further, manaakitanga means the art or the business of uplifting mana. It is the notion that motivates the tangata whenua of a marae to prepare haakari (feast) for manuhiri. But something else also happens in the haakari. As the tangata whenua exhibit their skill to host and feed manuhiri, they strengthen their own mana in the eyes of the manuhiri. At the same time, they also strengthen the mana of the manuhuri, as the size of the haakari symbolises their significance to the tangata whenua. Manaakitanga is the philosophical basis for a formula whereby, the mana of all parties is strengthened and, if mana is not strengthened, manaakitanga cannot be said to have taken place. 
Manaakitanga is a kaupapa that our old people shaped and that can be applied to how we integrate into the world as a whole. By recognising that all things of this world are interwoven and are kin to one another, one can connect all things of this world and see to the upholding of manaakitanga. Perhaps manaakitanga could be a new environmental philosophy, for example, whereby all contact with the natural world should be responsible for manaakitanga.

Alongside manaakitanga is the word $u t u$. The meaning of $u t u$ is best characterised as the principle of reciprocity. When translated into English it is defined as revenge but this is a coarse misrepresentation of its significance. Utu, as a concept, is based on the idea that anything acknowledged should be requited with a fitting return. As a measure of social control, Maaori society in customary times was directed completely by tikanga Maaori and $u t u$ was the motivating force used to manage conflict that may have involved kinonga (evil) and resulted in death, injury and harm to people. In return, gifts were exchanged in which the giving of goods, services and spouses involved in similar goods or taonga in return. $U t u$ as a concept when practiced remains an influential model, leading relationships in the Maaori political and social world, and linking individuals, whaanau, hapuu and iwi. It has the purpose of binding people together by the tuitui (criss-crossings) of reciprocal gifts and obligations (Metge, 1995).

\section{Mana}

To enable whanaungatanga to be preserved and sustained, mana as a concept mediates and guides the tikanga and kaupapa regarding this understanding. Maaori Marsden (1995) defines mana as authority and spiritual power whereas the Williams Dictionary (1957) describes mana as signifying a range of meanings such as control, authority, prestige, power, psychic force and influence. The application of mana involves a wide range of aspects and interpretations, which then enables it to be used in a broad range of situations. As a reader, you can draw your own interpretation and use this in the circumstances you envisage.

The views outlined show many interpretations of mana, which vary depending on the situation that arises, and can be adapted to suit the specific occasions. For instance, people who have leadership roles in the community tend to be endowed with mana and are well placed in terms of whakapapa and may come from a chiefly line or from important 
whaanau. It is from those tuupuna that people are able to draw their power and prestige because this has been socially endowed upon the whaanau, hapuu and iwi. Included in this is the personal growth of the person, supported by their skills, knowledge and the work they have contributed to the group over time. This gives an individual mana tangata (human authority). The importance of psychic power is highlighted by the value placed on whakapapa and the connections with the Gods acknowledged by Maaori. When listening to those leaders who claim a right to be a speaker on the paepae (speaker's bench) those who are most effective as speakers are those that have mana and confidence associated with it. This is recognised not only in their oral presentation but also in the actions they display when delivering their speeches.

The other aspect is the interconnectiveness of mana with tapu. This relationship is also highly connected with the concept of mauri. Within this research study individual kaupapa have been explored, but as Kathy Irwin (1995) contends, mana, tapu and mauri need to be explored together, because to separate them would result in an inaccurate interpretation. This then as a term is closely linked to the kaupapa of tapu, which could be referred to as authority, power, control, influence and prestige in relation to atua, people, whenua, and the environment. Mana is also linked to other concepts such as tuakana/teina, whakapapa and rangatiratanga, which are clear indicators of social relationships.

I believe that the kaupapa of mana and what it reflects is one that is individually earned and not one that is inherited, because as Charles Royal (1997c) notes, when viewed in a certain manner it becomes distorted and taken in a vein that can be detrimental to one's whaanau, hapuu and iwi. Especially in the contemporary society of today, when so many young Maaori people (especially males) have so much to deal with, they struggle to comprehend the significance of this kaupapa.

\section{Tapu}

To enable this, kaupapa to be understood, it is important to note that tapu has multiple meanings and conditions associated with it (Barlow, 2003) and I acknowledge the contribution of Ani Mikaere (1995) work within this section. Tapu was central to the everyday structure of social control for Maaori, which was a necessity for maintaining balance: a balance between people and the environment; the internal balance of each and 
every individual within the group; and, the balance within the whaanau, hapuu and iwi. The foundation of tapu is central to the complexes of daily life as it ensured the protection of spiritual balance, which was crucial to the survival and well-being of Maaori society.

There are two major aspects of tapu. The first involves spiritual prevention or protection and may be functional in a large gathering. Rose Pere (1982, p.2) contends that "tapu is the maintenance of social control and regulation". It would be impossible here to provide a broad discussion of such a complex institution. However, some examples of how tapu may function are informative and these will be outlined in the following.

Because the process for birthing was deemed tapu, childbirth could not take place in an ordinary dwelling house. Instead, a woman gave birth either in the open or in a temporary shelter, which was erected for this purpose and later burnt. This sanction allowed infection to be eradicated as everything was disposed off after the set period of confinement. This dwelling was called the whare koohanga - literally, the nest house. During the birth itself, the mother was assisted by her attendants, her parents other female relatives and her husband (Buck, 1958).

Another area significant for being tapu is that of the urupaa. As an area where people are to be buried, the sanctions around this are understandable. It is a place set apart where those who have deceased, can be buried. It is not an area that Maaori regard in any other light but that of being tapu and respected as such. An example of the purpose of tapu to people is the position known as the whaanau pani (the immediate family of the deceased) at a tangi (funeral). In many parts of the country, the whaanau pani, and the whare mate ${ }^{42}$ (house of death) are separated from the remainder of the hapuu and $i w i$ by virtue of their close connection with death. The haakari following the burial of their loved one is the custom whereby they are brought back into the sphere of the living. The second major kaupapa of tapu is what is called basic tapu. This is the acknowledgment of the basic importance of each individual and the holiness of each life. No individual stands unaccompanied; through the tapu of whakapapa people are connected to other members of the whaanau, hapuu and $i w i$ and to other Maaori as well. Every person is connected to the

\footnotetext{
${ }^{42}$ In previous times, an impermanent structure (a whare mate, literally, a dying house) would be built for a dying person. This allowed the tapu of death to be kept separate from any permanent building. After the death, the structure would be removed.
} 
generations yet to arrive and to those that have been previously, and people have a sanctified relationship to Papatuuaanuku and Ranginui and to the normal world around them. Moana Jackson (1988) refers to tapu from this perspective as the major cohesive force in Maaori life.

There is another form of tapu, which incorporates the body, bodily discharge and wastes. The head has always been regarded as the most tapu part of a person. For example, at a hui those who wait on the tables always take great care not to pass food over the heads of their visitors, for this would be considered as an offence. According to Moon (2003, p.89), in his book written on Hohepa Kereopa, he contends that "passing something over the top of someone's head was tapu as such" it was a commonsense thing, "because if you did this someone may get burnt if you spilt the hot contents on them". He goes on to say that Maaori did not have much furniture, but what was provided was for a purpose. Therefore, the toilet was for one's bottom to sit on and the bedroom was for sleeping in and not a place to consume food in. So for this purpose the significance of each article of furniture, was kept. Tapu is about being practical in these instances.

\section{Noa}

Pivotal to tapu being effective as a means of social control is the complementary institution of noa. It was defined as unrestricted access, ordinary, everyday, common and profane (Taiaroa, 2001). Vital to the whole process was the ability to impose restrictions through the use of tapu, whereas the capacity to remove such restrictions was through the kaupapa of noa. It is this thread that will now be unravelled.

Maaori believed that nothing in life and its experiences was worldly - that is beyond the reach of religious thought and practice. Noa therefore cannot be translated as worldly. Noa counterbalanced tapu, and as such it was an important component in the daily life of Maaori, their beliefs and customs (Orbell, 1998). It is difficult for Maaori to convey the meaning of noa using English interpretation, because the concept merges with so many other aspects of Maaori life, and cannot be given a narrow definition in English translations. Noa can be applied to everyday and day-by-day living situations, but it is also fundamental part of the intricate and prescribed social and ritual controls of Maaori as a people. The ability of noa to contribute to people's wellbeing by releasing them from any circumstance that makes them the focal point of customary rules, as well as the spiritual 
limitations and control associated with these social controls, needs to be understood. As a concept, noa is associated with kindness, revitalising, caring and productive influences, including that of ceremonial enhancement (Pere, 1997).

Another aspect of noa is what is known as whakanoa (to make noa or to lift the restriction of noa), which involves a ceremony that is conducted for this purpose. The process of whakanoa merely entailed the removal of some particular restriction imposed by tapu; it did not completely remove every trace of tapu. For example, the lifting of the particular tapu imposed on a whare (house) whilst it was being built did not then make the whare completely unrestricted. It simply meant that the particular restriction against anyone entering the building except those who were working on it was lifted, allowing the $i w i$ the freedom to enter and use the whare. However, the whare itself remained a tapu place in the sense that it represents a revered tuupuna, and many restrictions remained regarding the type of conduct performed within it. Equally, the removal of tapu from the whare mate on the final day of a tangihang $a^{43}$ did not mean that their inherent tapu is lost, or that they would not be subject to the same restriction of tapu in their daily lives, as for the rest of their kin (Mikaere, 1995).

Rose Pere (1997) notes that the kaupapa of noa is usually associated with benevolent, warm, constructive and life-giving influences, and has a special association with women who have the ability to whakanoa. It is high-ranking women ${ }^{44}$ who are the first to enter a completed whare tuupuna (house of the ancestors) thereby lifting the tapu. While it was possible for certain men to conduct whakanoa rituals, the special role that women played in such rituals, principally by virtue of being women, is an indication of the supremacy of their spiritual powers (Jenkins, 1986). The power of women to whakanoa is clearly of vital importance, for it establishes their ability to transverse the spiritual boundaries of tapu and noa, thereby nurturing and protecting their communities.

\footnotetext{
${ }^{43}$ Cleve Barlow (2003, p. 122) states that the "tangihanga or funeral ceremony is one of the few surviving institutions in Maaori culture. There are many traditions and customs associated with the tangihanga, and many important concepts concerning both the physical and metaphysical world are revealed here. Also many profound philosophies and ideas concerning Maaori cultural values and practices are talked about and performed on these occasions".

${ }^{44}$ Females chosen for this role seem to have either been women who had been through menopause or young girls of non-child bearing age.
} 
When exploring the kaupapa of noa it indicates a linkage to mythology, not only because Papatuuaanuku organs formed an integral part of the creation of the world, but the vagina is the pathway into this world for all human life and, through Hinenuitepoo (Goddess of death) the pathway out again. With respect to both the creation of the world and human life itself, the birth canal runs between the realms of Te Poo and Te Ao Maarama. The female role in negotiating the boundaries of tapu and noa reinforces and reflects the mythological blueprint for Maaori and their view of the world. It allows the social control of Maaori and their communities. The balance of this control depends on the ability to transverse between these two kaupapa without ramification.

\section{Mauri}

To capture what Maaori view as the mauri of a person, I refer to the Williams Dictionary (1957), which defines this as life principles. Mauri is the spark of life; the active component that indicates the person is alive, and within this body is the spiritual and mysterious quality of life. The heart beats, the many structures of human body carry out their detailed tasks, the blood moves, and body is vibrant and warm. However, once the life principles are extinguished, which is heralded by one's final breath, all body structures cease and the body becomes cold. Maaori view this as the mauri having left the body and the person dies. When the body expires the mauri ceases to live and totally disappears (Meads, 2003). Mauri is ever-present from the day we are born, and once we die it is extinguished. It is said that the mauri is gone and has left for areas unknown. There have been occasions in my nursing practice when old Maaori people have mentioned that when their loved ones are near death, they can feel the mauri of their tuupuna present within the confines of the room.

This kaupapa and the kaupapa previously discussed are integral to this research study. Defining and exploring each while being mindful that they have multiple meanings and are interwoven with each other will enable people to understand their importance in a nursing context. To successfully disassociate these kaupapa is like clearing away a piece of cobweb, to do so cleanly is difficult (Royal, 1997b).

\section{Wairuatanga}

Cleve Barlow (2003) contends that Maaori believe all things are born with wairuatanga, which means that one is born with a spirit or a soul. Maaori believed that human beings 
were fashioned from the elements of the earth and existed as a spirit that dwelt with the Gods. Their spiritual and physical bodies were then joined together as one by the mauri, the manawa ora (life-giving essence), which can be achieved at birth. This gives warmth and energy to the body so that it is able to grow and develop to maturity.

As a consequence of this belief in the immortality of wairuatanga, Maaori believe that the universe is inhabited by wairuatanga and believe that these human souls roam in forests, spaces and on mountains, and are all around us, although we cannot see them. The wairua that lives around the mountains and forests are known as tuurehu or patupaiarehe ${ }^{45}$. Cleve Barlow (2003) makes reference to the importance of the idea that when a person dies their physical remains are interred in the bosom of Papatuuaanuku, but the spirit lives on and travels the pathway of Taane to the Gods that created them. Here the spirit is no longer subject to death, but resides eternally in the company of the Gods. In contrast to Christian theology, there seems to be no support in Maaori philosophy for the suggestion of a rebirth, in which the body and spirit are reintegrated some time after death. But Maaori do believe that the spirit is everlasting.

As a kaupapa, wairua is interwoven with mauri. When a person is born, it is believed that the Gods unite the two parts of body and spirit, as one. It is only the mauri or the influence of God that can link them as such. When a person passes away, the mauri is no longer able to unite those parts as one, and the physical and spiritual parts of a person's being are divided. This is expressed in the following quote from Barlow (2003):

The heart provides the breath of life, but the mauri has the power to bind or join. Those who die have been released from this bond and the spirit ascends this pinnacle of death. The mauri enters and leaves at the veil, which separates the human world from the spirit realm.

\footnotetext{
${ }^{45}$ Patupaiarehe is similar to the English word fairy. In the interpretation of the word Paakehaa, Maaori first sighted and noted that these people were white and appeared like fairies or fair-skinned supernatural beings. Therefore the word Paakehaa is not a term of denigration in Maaori usage, but rather one of respect in associating the new settlers with supernatural beings or god-like people (at least in terms of their appearance).
} 


\section{Whenua}

The significance of whenua for Maaori is embedded in the creation of the world, particularly from a mythology, custom and $i w i$ histories continuum. Mythology reminded us about the position of Papatuuaanuku, who as the earth mother produced plants, birds, fish and animals for human sustenance. And, when a person dies they are then returned back to the bosom of Papatuuaanuku, where they are met by Hinenuitepoo. As a word, whenua carries a wide range of meanings. To Maaori it may mean land, but it can also mean placenta, country, state and ground. When reference is made to whenua as placenta, this sustains the connection of life between the foetus and the placenta through the umbilical cord. As a metaphor, it is the basis on which Maaori place high value on land. There are two aspects of whenua, the first is related to the placenta, and the second refers to the relationship with the land. How these are interconnected will be explored.

The whenua pertaining to birth is the means by which the mother and the child sustain new life. The child's link to the whaanau is by means of birth, whereby the whenua as land is the connecting link. The two whenua are similar and both are authentic. Whenua as placenta allows a foetus to develop into a baby, a small human being with all the likelihood of becoming a vigorous and sturdy adult. The person then grows and develops, and makes a contribution to Maaori society. When the child is born the placenta is returned and buried in the ground. The whenua therefore returns to the land, which is similar to the biblical idea of dust to dust (Meads, 2003). Papatuuaanuku is the earth mother, and it makes sense to Maaori that the whenua of the placenta is returned to whenua of land, and given back to Papatuuaanuku.

A significant part of the child is the umbilical cord, which is the vital link between the child and the placenta. A general word for umbilical cord is taangaegae, and this appears in ritual connotations and customary karakia. The shortest part nearest the baby's body is the pito, which means end bits. The part closest to the placenta is called the rauru and the piece between is called the iho. When the cord is cut at birth what is left is the pito. After about eight or so days it dries and drops off. The pito is collected put into its own receptacle and taken back to the $i w i$ homelands and buried. Some people bury the whenua and pito in two different locations because the dried pito is very small whereby the whenua or placenta is large by comparison (Walker, 1990). 
The second aspect of whenua is its relationship to land. Pere $(1982$, p.18) says, "The physical and spiritual wellbeing of the Maaori was linked to the whenua". This is not simple a figure of speech. A person can be seen as literally belonging to their tuupuna lands, rather than the lands belonging to a person, which clearly describes a person's obligation regarding this whenua. Maaori had a close empathy with the land that they claimed and occupied. The borders of that land, which was jointly owned, were clearly defined and carefully taught to the young. In most cases, a large area with lakes, streams, hills, valleys, fishing grounds and forests, was owned by an $i w i$. It was subdivided into areas owned by hapuu, and the cultivated portion were again subdivided and owned by whaanau. The appreciation and respect shown towards the conservation of the land should be promoted and encouraged. Conserving the land is important because once man makes changes to this landscape, man can never return it to its former glory. Maaori in customary times encouraged the need to live closely with nature, to understand and to learn about it (Pere, 1991).

\section{Rangatiratanga}

Rangatiratanga as a kaupapa was a term introduced and used as a political slogan. Missionary translators, who were looking for a word which approximated Maaori political management and organisations, used its alternative, tino rangatiratanga, in the Treaty of Waitangi ${ }^{46}$. They choose the word rangatiratanga, which has also been used as an interpretation of the word kingdom in the Lord's Prayer. Hence, the phrase thy kingdom come was translated as kia tae mai toou rangatiratanga and the word rangatiratanga has subsequently been linked with these missionary dealings (Royal, 1997b).

To understand rangatira we need to define the word. The term itself has been around for many centuries and is made up of two words: ranga, meaning to weave (as in raranga) and tira, which means a group of people or company of travellers. Therefore the role of rangatira is to link journeying groups together. As people embark upon journeys, rangatira take the role of uniting these groups into a shared cause. The role of the rangatira is to link groups, to unify people into a common cause either by identifying the cause itself or by supporting people to discover it themselves. This concept of binding our

\footnotetext{
${ }^{46}$ The Treaty of Waitangi was a document signed in 1840 by both Maaori and Paakehaa. It became a living document representing for Maaori, protection, participation and partnership. As time has progressed this has been difficult to achieve and become a contentious issue. I will refer to Te Tiriti o Waitangi in relation to anything referring to Maaori and the Treaty of Waitangi in relation to matters belonging to Paakehaa.
} 
people was so important to our tuupuna, that they included it in the word rangatira itself. Therefore the term rangatiratanga, which extends rangatira with the suffix tanga, now includes the business of rangatira. Rangatiratanga is the business of binding groups together. Notice that this does not mean the business of being a leader, but the business of ranga (binding) tira (groups).

\section{Kaitiakitanga}

The work of Maaori Marsden (2003) and Charles Royal (1997b) contributed greatly to this section, in which I will define the kaupapa of kaitiakitanga. The basic meaning of tiaki is to guard although with all these concepts they have closely related meanings depending upon the context. Hence, tiaki means to preserve, to keep, to protect, to foster, to conserve, to keep, to watch over and to shelter. The prefix kai with a verb denotes the agent of the act. A kaitaiki is a preserver, keeper, guardian, protector, foster parent and conservator. The suffix tanga when added to the noun transforms the term to preservation, conservation, guardianship, sheltering, protecting and fostering. The word kaitiakitanga is used by Maaori to define conservation, traditions and customs, including its purpose and means through raahui ${ }^{47}$.

There are premises we need to consider when viewing kaitiakitanga as the meaning often depends on the situation it is reflecting. Mason Durie (1999) in terms of the New Zealand Resource Management Act 1991, outlines the significance of kaitiakitanga. When defined means guardianship or stewardship (Ministry for the Environment, 1994). Stewardship is not an appropriate definition since the original interpretation from an English perspective means to guard someone else's property. Apart from having implications of a master/servant relationship, ownership of property in the pre-contact period was an unfamiliar concept. The closest idea to ownership was that of personal use of a limited number of personal things such as garments or weapons. Apart from this, all other use of land, forest, fisheries, and waterways was communal or an $i w i$ right. All natural resources, which were given birth to by Papatuuaanuku were acknowledged as such. Thus the resources of the earth did not belong to man, but man belongs to the earth. Man as well as

\footnotetext{
${ }^{47}$ The institution of raahui was designed to prohibit depletion, exploitation and degeneration of resources and the pollution of the environment to avoid the collapse of the biological and ecosystem of Papatuuaanuku. Further explanation has been given on raahui in the section on tapu.
} 
animals, fish and birds could harvest the bounties of Papatuuaanuku resources but they did not own them. Hence the idea that man had user rights over the earth.

Another premise is the word kaitiaki or guardian, which, we use to refer to the guardian spirit left behind by deceased tuupuna to watch over their descendants and to protect sacred places. Kaitiaki are also messengers and means of communication between the spirit realm and the human world. There are many representations of guardian spirits, but the most common are birds, insects, animals and fish. In Ngaa Puhi for example the kaitiaki of Cleve Barlow's area is the owl and in the event of the death of a relative, the owl will appear and utter a special cry to close kin, forewarning them of the event (Barlow, 2003). Many other $i w i$ relate to the idea of kaitiaki, and have their own special stories about them and signs by which they can be recognised.

\section{Tohungatanga}

The word tohunga is often translated as expert. Such use is incorrect and stems from the misguided idea that because the Maaori used this term in relationship with recognised experts in a particular field the word means experts (Nicholson, 2006).

We need to consider the word tohungatanga in the contexts in which it is being used, in order to understand its meaning. The word tohunga is derived from the stem tohu which as a verb means a sign or symbol. Hence, tohunga is the gerundive of tohu and means a chosen one or appointed one. Tohu also means to mark or indicate. This kaupapa is included in the word tohunga (found within tohunga), which means expert. In the Maaori view experts are those who are somehow distinct or recognised as being especially skilled and knowledgeable in a given field. Further, a tohunga is a person who is skilful with symbols or signs who understands them and knows how to use them. Tohunga also create new symbols or signs and can expand these symbols or signs like whakapapa and language. The role of the tohunga is a motivating feature of Maaori society. These days we tend to believe tohunga are people who perform the rituals associated with opening a wharenui or who are healers. However, the term tohunga is generic term for experts of any field. Therefore, you have tohunga whakairo or expert/master carvers or tohunga raranga or master/expert weaver. There are numerous kinds of tohunga. 
Tohungatanga might be interpreted to mean expertise, however, this needs to be extended a little more. It may seem that tohungatanga is a puutaketake ${ }^{48}$ (root) not only of Te Tiriti but also of Te Ao Maarama. It is a root that nurtures all things within Te Ao Maarama, so that in a human sense tohungatanga exists in all people. Much of life, therefore, is about accepting and exploring one's own tohungatanga.

Concerning tohungatanga and the person, Royal (1997b) indicates that this means the gifts, potentialities and abilities, a person is gifted with from birth. Life is about exploring these gifts and potentialities, and this is referred to as tohungatanga. Further, in order to truly understand a thing like aptitude, we humans create symbols or signs so we can understand it. For example, we create education systems which reward learning (through qualifications like diplomas and degrees) and these reward signify an individual's aptitude or expertise; their tohungatanga.

\section{Uukaipootanga}

Like the other kaupapa noted and explored, uukaipootanga is intensely spiritual. If we pull the word apart, we find that it is made up of three words: $u u, k a i$ and poo. $U u$ is the word for mother's milk, kai in this example means to consume and poo means the night. Literally, the word uukaipoo means the mother's milk that consumes the night, which is rather a strange expression. However, if we think about this term closely, we find that it is a symbol or sign. The mother's milk that consumes the night is a symbol or sign for those spaces and places in which we are nurtured and improve like a baby who suckles at his/her mother's breast. Uukaipoo ${ }^{49}$ refers to those places where we go to renew our energies; those places that remind us of the important things in life, where we are reaffirmed of our own uniqueness and orientation within the world.

There is a whakataukii that states, E hoki koe ko too uukaipoo, kia purea koe e ngaa hau o Taawhirimaatea, (Return to your uukaipoo, and be cleansed in the winds of Taawhirimaatea). As the every day grind of life wears us down, we need those special times and places where we can be cleansed by Taawhirimaatea. This practice likens those

\footnotetext{
${ }^{48}$ Charles Royal (1997b, p. 35) interpretation of "puutaketake or root is that custom applies the symbol of the tree to Te Tiriti and states that if the correct roots are in place, the tree will flourish and bloom. These correct roots are rangatiratanga, whanaungatanga, manaakitanga, tohungatanga, kootahitanga and uukaipootanga. If these roots are in place then Te Tiriti shall flourish like a healthy tree".

${ }^{49}$ Iwi Nicholson (2006) conveys that uukaipoo is often used to indicate where a person was born, raised or nurtured; the place where the individual was nurtured and suckled on the breast of the mother at night.
} 
spaces and places to a mother's breast, a unique place where one is nurtured. These places reconnect you with a deeper acceptance of yourself, of your own uniqueness and it nurtures you as a mother's milk nurtures a newborn child.

These spaces and places can be anything and anywhere, and only you know where they are for you. In the whakataukii above, the uukaipoo is visualised as an immense mountain where the winds of Taawhirimaatea blow. However, your unkaipoo might be a much more personal place. It might be in the type of music you like, a music, which reminds you of the things that truly inspire you and is in keeping with your own view of your true self. It might be in the speeches of a great leader or in the soothing words of a beloved kaumaatua. Whatever it is and where ever it might be, only you know where it is.

How do we know that we have found our own uukaipoo? There is an experience that most go through as teenagers. One gets to a certain age and experiences something that reveals a deeper side of oneself, a first time experience of getting to know oneself. It can be a rapturous experience. It might be an experience that happens on a sport field where everything goes right, where you never do anything else more competently in your life than in the moment of inspiration where you net a goal or score a try. It might be a piece of music one performs or hears, or some poetry or some other kind of experience. Whatever it is, it mysteriously reveals to you for the first time, who you truly are, and why you are here. The revelation that takes place shows what you could be.

\section{Kootahitanga}

Kootahitanga is a kaupapa within Maatauranga Maaori that enhances unity (Reed Dictionary, 1999). Our tuupuna understood this deeply and this is evident in whakapapa, which seeks to make connections, and therefore show kootahitanga, between all things in the world. It is Te Ao Maarama custom, which places Papatuuaanuku and Ranginui as the parents of creation, demonstrates this unity. However, as Papatuuaanuku and Ranginui were separated, this symbolises the sense of separateness and division that we experience in the world. The Biblical story of the Garden of Eden is a mythological explanation (according to some people) of the passage from unity to separateness. While Adam and Eve are in the garden and God is also present, he orders them not to eat the fruit of the tree of knowledge and when they do so, suddenly the separateness occurs. They are separated and become aware of each other, whereby they hide their shame. Where once they were 
unified and had no shame, having eaten the fruit they are divided and are cast from the garden. The banishment from the garden is symbolic of the movement from the world of unity, peace and divinity to the world of duality, of opposites, of good and evil, of day and night and so on.

Equally, this movement from kootahitanga to a sense of separateness and duality is symbolised in the separation of Papatuuaanuku and Ranginui. Where there was one, now there are two: there is now female and male, day and night, tapu and noa and so on. It can be said that all mythological and religious customs recognise the fundamental passage from unity to division. In the Christian belief, this world of unity is symbolised in heaven and personalised by God. In Maaori customs is symbolised in the Io, Te Poo and Te Kore and in the kaupapa of kootahitanga.

As a kaupapa, kootahitanga as a political slogan is heard in various national Maaori movements, such as the Parliament of the last century, the Contemporary National Maaori Congress, in the Kiingitanga movement as well as the new contemporary Maaori political party. Kootahitanga is debated constantly in hapuu and $i w i$ settings and we are reminded of kootahitanga in such concept as whanaungatanga. Despite the great amount of energy spent in discussing it however, kootahitanga remains an illusive goal, often raised but seldom met in this particular forum.

If kootahitanga is to be achievable, whaanau, hapuu and iwi must be ready to spend their energy and time in becoming acquainted with each other. They need, to work through disparities in lengthy discussions and attempt to reach a consensus, keeping whaanau matters private from outsiders, and be able to depend on each other in challenges with outsiders. It also means we must accept accountability for each other's dealings, acting to avert or manage damage and if need be, helping to give compensation to outsiders in order to reinstate the whaanau, hapuu and iwi mana (Metge, 1995).

\section{Tikanga}

The importance of tikanga to Maaori is that it means the Maaori way or done according to Maaori custom (Meads, 2003), whereas Williams Dictionary (1971) defines tikanga as custom, rule, method, plan and habit. It is these sets of beliefs associated with procedures and practices that allow people to conduct their affairs as a group or as individuals. These 
procedures are set through time, are held ritually correct and are validated by more than one generation. They are always focused on what a group, an individual or a whaanau, hapuu or $i w i$ is able to do. What is important to note is that tikanga can be viewed in several ways, which has been indicated in the definition of the word. But it is obvious that to consider tikanga in this context should be considered as part of social control. It enhances interpersonal relationships, provides ways for groups to meet and interact, and even determines how people identify themselves (Meads, 2003).

Maaori Marsden's (2003) work will be an important contribution throughout the following discussion. Tikanga as a tool can capture understandings and thoughts. It is a package of ideas, which help to organise behaviour and provide some consistency in how certain actions are carried out. It provides a guide or framework to direct one's actions and helps guide people through large gatherings and apprehensive moments in ceremonial situations. As a concept tikanga helps people to distinguish between right and wrong, and acts as a reminder that there is a correct and accurate way of doing things.

As a knowledge base, tikanga is inherent within Maatauranga Maaori and as such, is the base upon which explanations, thoughts and adjustments are made by generations of Maaori. Often adjustments are so small it is hardly evident, but it all adds to the pool of knowledge about a particular tikanga. Kaupapa that have been identified in this chapter of this research study and many other studies, all play a part in explaining our tikanga associated with the continued existence of Maaori as a people.

Tikanga Maaori translates as Maaori custom and at the same time denotes those aspects of life that have been handed down through many generations, which are accepted as a reliable and appropriate way of achieving certain objectives and goals. Such proven methods together with their accompanying kawa, are integrated into the general cultural institution of the society and incorporated into the cultural system of standards, values and beliefs.

All tikanga are firmly embedded in Maatauranga Maaori, which can be seen as Maaori philosophies and values as well as Maaori knowledge. While Maatauranga Maaori might be carried in the brain, tikanga puts that knowledge into practice. It also adds the feature of truth and provides the support needed to put these ideas into action. People then view tikanga in action. They do it, sense it, recognise it, acknowledge it and feel embedded 
through experience. Tikanga then, may be described as Maaori philosophy in practice, and as the practical aspect of Maatauranga Maaori (Meads, 2003). When one considers tikanga, one needs to consider kaupapa as they are all interlinked and interwoven. They need to be put side by side in Maaori thinking and viewed from that particular continuum.

\section{Kaupapa}

Kaupapa is derived from two word, kau and papa. In this context kau means to appear for the first time, to come into view, and to disclose. Papa means ground or foundation. Hence, kaupapa means ground rules, first principles and general principles. Kaupapa and tikanga are interconnected in Maaori thinking and inherent in Maatauranga Maaori, therefore they need to be explored together as part of this research study (Royal, 2004).

When contemplating some important plan, circumstances or achievement that needs to be attended to and determined, the iwi in council would discuss the kaupapa or rules and principles by which they would be guided. There is an appeal to first principles in cases of doubt or uncertainty, and those principles are drawn from the creation stories, the acts of the Gods in the period of transition following the separation of Papatuuaanuku and Ranginui, or the acts of the myth heroes such as Maaui and numerous others. The methods and plans they used in similar situations are recommended and recounted, as well as those alternative options they have examined. From this a course of action or tikanga is adopted (Marsden, 2003).

In more everyday circumstances, kaupapa is a word that is used widely throughout Maaoridom and it has a number of meanings. According to Barlow (2003), the usage of kaupapa has many examples across a range of contexts. One such context is the process of deciding on the theme of a wharenui. When a new wharenui is being built, the kaupapa of the house refers to such things as the tuupuna after whom the house is to be named, the different tuupuna figures to be carved on the support posts around the perimeter of the house and the painting and other decorative work. Kaupapa can also refer to marae kawa. Here the term kaupapa refers to the politics and rules associated with the administration of a marae and, in particular, the kawa for formal speech-making, for the karanga for welcoming guests and, in the case of a tangi. 
The context and situation determines kaupapa and guides the action or principles to be used. The tikanga is the method by which these actions are to be adopted. If we were to view this from a Paakehaa perspective, tikanga is the ethical principles and kaupapa is the action or principles to be used. The ability to interlink these two kaupapa is important to everyday situations for Maaori. The adoption of such aspects allows these kaupapa to be incorporated into the social system of values, attitudes, beliefs and standards.

\section{Te Reo Maaori}

\section{Oral word}

The backbone of Maaori existence involved their history that link to those tuupuna now passed on (Binney and Chaplin, 2004) inclusive of their whaanau, haapu and iwi. The language, which they communicated, was known as te reo Maaori and memory was the central mode by which they exchanged knowledge (Makereti, 1986). It was through this form of oral communication and transmission that stories were told and retold allowing Maaori as a people to become proficient storytellers. What has been recorded by these six participants are their unique experiences relating to their people, which includes oral accounts and is disclosed in Chapters 4 and 5.

The most fundamental and important aspect concerning Maaori and how they view the world is through the acquisition of their language - namely te reo Maaori. This sense of determination continues in contemporary society to ensure the advancement of the language and its meaning. There are Indigenous people who support this stance, as their oral customs have enabled the advancement of their knowledge and language. For example Christians, (1980), Gillespie, (1975), Grosvenor, (1970), Noble, (1978) and, Washington, (1979), are black American women writers who have written on this means of transmission.

The significance of te reo Maaori as a language is that it is the vehicle by which mythology, iwi histories, thoughts, tikanga, kaupapa, hopes, desires, frustrations, dreams and knowledge are communicated from one person to another, all of which are important to this research study. It has been said that a people without their own language have no identity or power (Barlow, 2003). Meads (2003) states a word one understands through te reo Maaori is different from one obtained through the English language. This is due particularly to the fact that Maaori reo participants usually have the advantage of prior experience and knowledge. When we translate an English word into its literal equivalent 
in another language, we often think that the words have the same meaning. While many words do have generally the same meanings in different languages, they often have different nuances and implications (Suzuki, 1978). Also, the connection people of different cultures have with the same word may be different. When considering the relationship between words in our language and their translated equivalent in another, we should not view those translations as exactly equal.

If one is to gauge how the delivery of the oral language is to be conducted, we need to visit the formal process that occurs on a marae. First, the women of the marae will perform the karanga which will allow the clearing of the way for the manuhuri to precede onto the marae. Then the orators speak and perform the duties expected of them when these occasions occur. Central to any distinguishable orators' whaikoorero is the ability of the person delivering the whaikoorero to ensure it is structured from the prescribed sequence of topics. These topics will vary according to the occasion and the role of the speaker, and are expressed according to mythological repertoire. Once the orators from both sides have completed their role, then the women from each side will perform a waiata. A koha (gift) is given by the manuhuri to the tangata whenua, and normally occurs at the end of the whaikoorero. In customary times, this was in the form of kai (food) ${ }^{50}$ or taonga, which could for example, be weapons or finely woven cloaks. Once speeches are finished, waiata is completed and koha collected, then the manuhiri speakers lead the hongi ${ }^{51}$ (pressing of noses). The hongi completes the formality of the poowhiri (welcome ceremony). The whole process of the poowhiri is a gradual coming together of the manuhiri and the tangata whenua, concluding with the physical contact of the hongi. However, the rituals of encounter are only fully completed by the sharing of kai.

Once the formality is finished on the marae, the manuhiri are invited to partake of the kai. Kai is important because it serves to whakanoa the manuhiri from the whole process of the poowhiri. The importance of sharing kai is also significant to the practice of manaakitanga. This denotes the act of generosity to all. To end a hui a formal farewell

\footnotetext{
${ }^{50}$ In the customary days kai was given but was not always placed on the ground of the marae, instead it was taken directly to the kitchen to be used for consumption.

${ }^{51}$ The hongi represents the passing of breath of two people. This reflects the story of Taane and the creation of Hineahuone, the first woman who was made from the clay of Hawaiiki. In his creation of Hineahuone, Taane brought life to her by breathing into her nose and mouth, upon which she sneezed, explaining, "Tihei mauri ora (the sneeze of life). This phrase is used to indicate the beginning of a whaikoorero; therefore, this narrative of the creation of the first human is not only significant to the hongi but to the whaikoorero as well.
} 
takes place and this is known as a poroporoaki (leavetaking). The manuhiri normally begin this process, followed by the tangata whenua. The visitors will acknowledge the act of manaakitanga by all, particular the ringa wera (kitchen hands) who have provided the visitors with sustenance throughout the hui. What has been outlined is part of the formal process recognised on the marae, which allows the acknowledgement and delivery of oral communication in the various format known to Maaori and how they view the world. Another large and important component is the use of non-verbal communication, such as facial expressions, hand movements, tone, posture, dress and, distance. These are all part of the way in which Maaori express their thoughts and feelings while participating in marae activities and settings.

In reading and thinking around these various oral forms of communication, there are various mnemonic or aide-memories devices used to convey this knowledge. These devices were in the form of whakairo, whai moko (body tattooing), weaving, tuhi (physical marking) tukutuku and tohu (metaphysical or physical signs) to name but a few. When they were conveyed in figurative form and in sequence, this made the preservation of oral histories and customs known to Maaori easier. Whakairo - probably the most visible mnemonic system in Maaori society - has become important in this area over the last century. The carved whare tuupuna have been likened to learning centres and libraries (Jenkins, 1991) with the whakairo being seen as books of knowledge. These highly prized figurative forms with their elaborate patterns were carved into wood to memorialise tuupuna and the tikanga linked with them (Haami, 2004). These carved houses were not considered important simply for their appearances. They were seen to personify the customary stories and the knowledge people gained from the whakairo. The significance of puuraakau or the customary method of storytelling is highlighted by Tau (1999), who describes this form of oral tikanga as the act of whakairo a puu (tradition) upon raakau (wood). According to this meaning, the whakairo entails the tikanga and kaupapa of the community, just as the word is a signifier of thought and reflection (Mead, 1984).

Other means of oral communication have been through the many means of songs and one person in particular of note is Sir Aapirana Ngata (1928) who collated and recorded within his works, known as Ngaa Mooteatea, vast accounts of composers and their compositions. He also divided waiata into various literary forms and broad categories such as: oriori, karakia, waiata aroha (songs of love), waiata tangi (songs of death), paatere (abusive 
songs), rangi poi (poi dances), tauparapara (opening chants), pao and ruri (short spontaneous songs), whakaaraara (watch cries), mata (prophetic songs), mataara (alarm songs), haka and ngeri (posture dances), and other similar forms. Some are, now rarely heard, although performances and many texts have been recorded (Simmons and Penfold, 2003). To accompany these various songs, music was also part of this activity (Flintoff, 2005).

The contribution of oral commentaries is a very important part of this research study and the whakapapa and life-stories of the six participants indicate the value of this means of communication. Work written by Maaori and Indigenous writers and researchers indicate the value of oral commentary as a way forward for research studies of this proportion (Bulan, 2005; Bull, 2005; M. Durie, 2004; Lee, 2005; Nicholson, 2006; M. Selby, 2006; Vanderwerth, 1971 and, W. Winiata, 2005). From the beginning of this study it was stated that oral stories would be the way in which literature would be gathered as it is a method of rigour that adds validity to this study as indicated in Chapter 1, 3, 4 and 5 .

\section{Written word}

One other important means of conveying the whakapapa and life-stories of the six participants has been through the recourse of the written language. The introduction of the written word changed the whole way in which Maaori communicated. Where once knowledge was expressed by oral means or memory, it was now being replaced by the written expression. It was once said that a literate person could never fully recover the sense of what the word is, compared to one who uses purely oral (Ong, 1995, p.5) means. In ancient Greece it was known as the winged word where its only residues lay in the memory of the listener (Thomas, 1989). These thoughts themselves take wings, inseparable from speech, and like a bird in flight, is never there but always gone. In customary times when the written word was introduced, Maaori depicted and personified birds as an embolic symbol in their writings. Also within the creation of musical composition, the use of a bird-like symbol was maintained by Maaori (Flintoff, 2005). What intrigued Maaori was that words written on paper could have meaning, could talk, and could elicit a response. This opened up a new train of thought and communication for Maaori. Kuni Jenkins (1991, p.12) contends, "the world the Maaori knew before the written word, would be far removed from what they now know". 
The traders, missionaries and whalers who ventured to the shores of Aotearoa brought with them this written language. Notably, the first attempt at introducing this technique of the written word to Maaori occurred in Parramatta, near Sydney in the late eighteenth or earlier nineteenth century. The first students were Maaori men who joined a Paakehaa whaling crew stationed at Parramatta. There, the Church Missionary Society led by the Reverend Samuel Marsden encouraged these men to attend the mission school in the hope they would convert to Christianity, enabling them to deliver the message back to their people (Haami, 2004).

One of the earliest methods for regenerating the language has been through the activity of publishing books such as the Bible and hymnbooks, written entirely in the Maaori language. Work by Jane McRae (2004) will make an important contribution to this section. To inform Maaori of European life, Government documentation and literature was produced for publication as well as more than forty titles produced from the 1840 s into the twentieth century, through the medium of newspapers. Maaori themselves produced the highly political Te Waananga in 1874 and humanitarian works such as Te Korimako during the period $1882-1888$. These published writings are remarkable as Maaori wrote about political and social problems and demonstrated the adaptation of the oral arts for the press. They used quotation of personal or private letters, songs, iwi history and articles on customary tributes and obituaries of farewell. Around the late 1820s Maaori began the full use of the written word. This came about with the expansion of the Maaori King movement, which set up the first independent Maaori press and created the first Maaori newspaper called Te Hokioi (the mysterious night bird) for publication (Orbell, 1998).

The introduction of Europeans who visited the shores of Aotearoa (McRae, 2000) saw the shift from the oral tikanga and kaupapa to written language. They brought with them their own values and beliefs regarding the written word and how it should be engaged and implemented for and by Maaori. There were publications by Sir George Grey in the $1850 \mathrm{~s}$ that resulted in a collection of narratives, songs and sayings, as well as a publication by John White (1887) of the six-volume, bilingual The Ancient History of the Maaori. The material was obtained from Maaori and was edited for publication. Other contribution to the large manuscript legacy left by Grey were made by Wiremu Maihi Te Rangikaaheke, only a little of which has been published (Curnow, 1958). Maaori creatively wrote 
recordings of whakapapa, iwi histories, religion, customary practices and songs in the nineteenth century. Some written submissions to the Journal of the Polynesian Society in the 1890 s resulted in valuable sources of Maaori oral literature being produced.

The writing produced in the twentieth century indicated that the contribution of Maaori literature was relatively small, due to the decline in speakers of the Maaori language. The writings produced by the ethnographer Percy Smith (1915) in Lore of the Whare Waananga, which captured the evolution of the world, and Gods, waka migrations to Aotearoa, and translation such as Pei Te Hurinui Jones Te Tangata Whai-rawa o Weniti (The merchant of Venice) were contributions to the literature. From the 1970s, oral texts and translations appeared in journals - such as Te Ao Hou/ The new world, which housed the work of scholars such as Hirini Meads, Margaret Orbell, Bruce Briggs and Agethe Thorton. In the $1980 \mathrm{~s}$, Maaori began to respond to this literature by making it $i w i$ focused and by producing their tuupuna manuscripts, for example Arnold Reedy's (1997) editing of Pita Kaapiti teachings about $i w i$ and practices of hunting and cultivation and Ngaati Porou tuupuna.

The late twentieth century saw the establishment of a new style of literature and publication for Maaori, which resulted in an exchange of literacy and oral styles. Fiction writing includes poetry, short stories and children's stories; non-fiction, includes biographies and collected writings. A small amount of this new work came with a translation into English, a tribute to the aspiration for the survival of the language. Also obvious is the large amount of children's literature in Maaori, which has been rewritten to include the classics of the oral tikanga, and communicates a different form of contemporary life within and outside Maaori settings. There has been a revitalisation of the Maaori language, which has created a demand for these publications.

The creative works of Maaori writers such as Witi Ihimaera, who wrote Te Kaieke Tohoraa (The whale rider) the Shakespearean sonnets by Merimeri Penfolds (2000) and her original works such as the short stories of Ngaa Pakiwaitara, all adapt and combine customary themes with modern social opportunities. These adaptations captured the messages and nuances of these Maaori writers. What resulted was the increase of Maaori literature in non-fiction publications. The collections of these articles were on political, wairua and social subjects. These consisted of letters to newspapers, which were, 
collected for publication by $i w i$ kin, such as Wiremu and Te Ohorere Kaa (1996) editing of Aapirana Ngata writings. Biographies recollect the focus on a single character in the oral narratives, and include not only the many biographies published in Ngaa Tangata Taumata Rau (the Maaori editions of the Dictionary of New Zealand Biography) but also those published by individuals. Ruka Broughton (1979) merges oral and written history in his biography of the famous Ngaati Ruanui leader, Tiitokowaru. Te Onehou Phillis (2001) writes about her father Eruera Manuera. Hemi Pootatau (1991) charts a new course with an autobiography, He Hokinga Mahara. Ranginui Walker's (2001) biography on He Tipua: The life and times of Sir Aapirana Ngata is another. There has been a publication written by Paul Diamond (2004) called Fire in My Belly, which extols the understanding of rangatiratanga by a number of Maaori men and woman, who relate this concept to the pathway they have taken to ensure that the survival of Maaori as a people is paramount to their cause.

The understanding and writing of poetry by Maaori has been an interesting discovery, and within her works Reina Whaitiri (2006, p. 81) takes the reader on an informed journey into this literary world. Jacquie Storm was the first Maaori author of fiction writing to be published in English, and her poetry became known through a student newspaper and other publications as early as 1940. Her collection of short stories, The House of the Talking Cat, was not published till 1983. Other renowned published works was that of Hone Tuwhare, whose poetry was printed in local magazine, poetry yearbooks and the Maaori journal Te Ao Hou. His collection of literary work in this area is world acclaimed, and it was in 1964 his first collection of poetry No Ordinary Sun, was published. This set the scene for his life-long passion to be acknowledged as a Maaori writer. Another person to mention is Roma Potiki (1992) who is a poet, artist and playwright. Her work Stones in Her Mouth was vital because it spoke for and about Maaori women, mothers, big women, abused women, funny women and women left alone to raise children. Another contemporary writer is Robert Sullivan, who as a poet is the voice for the raising of young, educated contemporary and urban Maaori. When relaying her understanding of him, Whaitiri refers to him as a sophisticated, passionate and learned young man who is driven by musical impulse. His work is becoming renowned in the literary field both nationally and internationally. 
Other areas, which have contributed to the language revival, are broadcasting and television. First, the introduction of the language into broadcasting and print media was the work produced and undertaken by Derek Tini Fox ${ }^{52}$. Despite resistance from colleagues and limited resources at his disposable, Fox consistently argued for a stronger Maaori presence. In 1993 he established Mana news radio broadcast and launched Mana, a Maaori news magazine for all New Zealanders. Though written in English, the magazine contains articles in Maaori and includes a wide range of contemporary material related to Maaori, which included emphases on sports, health, education and politics. Second, television became a media instrumental in the revival of the language. Professor Whatarangi Winiata led this movement towards the use of television as an area for advancement of the Maaori language. He played a pivotal role in ensuring that this means of transmission was used for the advantage of the language that was being introduced into this format. Its introduction did not run smoothly, as there were obstacles put in the way of Maaori to achieve this, but it finally came to fruition in May 1996, when a Maaori television channel - Aotearoa television network - commenced broadcasting (Durie, 2002) in te reo Maaori.

Another, area that contributed to recording and transmission of the Maaori language using other media, was the National Film unit, which began in the 1940s and was originally part of the Prime Ministers' department. It produced a news magazine called The Weekly Review, as well as tourist films and documentaries. Featured in this film unit was a black and white instalment of a native school with Maaori children, located on the East Coast. The film emphasised that the school provides training for living ... not a specialist training for Maaori girls. This training included access to modern homes and a special class-room for cooking, cleaning and making beds. For Maaori boys, the whole land is a classroom. It was noted that the language and the culture of Maaori played a small part in these film productions and the focus was mainly on the assimilation of Maaori into Paakehaa methods of home craft and farming, as was salient in the aforementioned film (Allender, 1951).

Another major significant event during the twentieth century was the resurgence of the language through the Koohanga reo movement (1982). These institutions provide a total immersion in the Maaori language, culture and values for preschool children. It has been described as one of the most noteworthy events to happen to Maaori society in the

\footnotetext{
${ }^{52}$ Known as Derek Tini Fox of Ngaati Porou and Ngaati Kahungunu iwi affiliation. Fox is brother to the late Becky Fox, recognised for her work with Maaori women and the experience of birthing.
} 
twentieth century. Koohanga reo can be seen as the latest expression of community empowerment that has been an ongoing theme throughout the period of this movement within Aotearoa. This then led to the establishment of Kura Kaupapa and finally to the Whare Waananga, where the Maaori language is on the lips of children and those students who wish to engage with te reo Maaori. Where once the Maaori language was in a state of crisis, or as some linguists would describe it, on the verge of language death (L. Smith, 2002), what has occurred is the resurrengence and restoration of te reo Maaori, which has allowed the understanding and acquisition of such knowledge to flourish and grow.

One must acknowledge the development of a Maaori publishing firm named Huia Publishers, which in today's contemporary society has contributed to the treasure trove of literature being published for and about Maaori in both te reo Maaori and English. Acknowledgement also needs to be given to Reed Publishers, who have published Maaori writers' work since the early 1970s and are responsible for over sixty percent of these works being published in Aotearoa. We have reached a milestone in our history of being Maaori when our literature has its own house of publication (Whaitiri, 2006).

Literature written in Maaori (and its translation to English) has gone someway to diminish the sense of loss that has occurred since colonisation, as has the use of various means of broadcasting, films and television to achieve this revival. The various Maaori movements have also contributed to the advancement of the language. It is these various written works and other means that have enabled Maaori since the introduction of the written format, to communicate the historical aspects of $i w i$, customary and mythological knowledge, although one must not forget the importance of oral composition to Maaori as a people. It is through these oral compositions that the understanding of how we as Maaori view the world becomes clear, which is especially important to this research study. It enlightens people to the value of incorporating a Maatauranga Maaori continuum into everything we do as a people. It has allowed the introduction of broadcasting, films and television to play a role in this revival, as well as other major movements that have influenced and developed the communication of the Maaori language.

As we have engaged in an exploration around the oral and written language of Maaori as a people, one important aspect that will become evident is that inherent within Maatauranga Maaori are the oral tikanga and kaupapa that are presented through one's stories or life 
stories. This is important to this research study, as the whakapapa and life-stories revealed in Chapters 4 and 5 represent the way in which the six participants endeavour to reflect, relate, engage, observe and claim the value of the Maatauranga Maaori epistemological framework as a means to seek answers to questions that arise when caring for our people.

In section 2, the value of the customary Whare Waananga will be explored, to give an insight into how knowledge was transmitted to those tauira (pupils) who engaged in studies in this particular period.

\section{Section 2 Customary Whare Waananga}

In order to acquire the ability to understand the knowledge of our tuupuna and that of Maatauranga Maaori, we had what is known as Whare Waananga. The importance of this to the research study under exploration will be outlined and discussed. Customary Whare Waananga were iwi centres of higher learning in pre-contact Maaori culture. Numerous examples of the customary Whare Waananga were located throughout Aotearoa and a great deal of information about them has been preserved. The curriculum of these $i w i$ institutions was wide ranging, and included astronomy, whakapapa (as an analytical tool), navigation, history, agriculture, philosophy, arts and literature. Whilst these Whare Waananga were maintained by particular $i w i$, much correspondence and interaction took place between these institutions and across $i w i$ boundaries. This interaction was actively encouraged even between so-called iwi enemies (Royal, 1998b).

To engage the readers with the development as an institute of that era, I will refer to Maaori Marsden's (2003) work on this topic. These Whare Waananga were establishments of higher learning, which was termed Te Kauaerunga (literally the upper jaw). Other establishments of learning such as the Whare Maire were connected with occult lore, and certain forms of karakia and others were termed Te Kauaeraro (literally the lower jaw).

Prior to admission into the waananga, applicants or tauira were selected and screened, and were required to go through certain cleansing and initiation rituals. These rituals included pledging loyalty to a particular tutelary divinity such as Taanemahuta, Tangaroa (God of the sea) and Rongo (God of peace) in relation to the major specialisation that tauira wished to follow. The Whare Waananga was convened in the wintertime after the cultivation of 
the sweet potatoes and the gathering of seafood had been completed. When the tauira arrive, they were baptised by priest and taken to the waters of $k a t u^{53}$. The first action of the tauira when entering into the waananga was to proceed to the rear ridge pole, pick up and place hukatai - the white stone - in one's mouth and emblematically swallow it, after which a tauira would return it. This symbolised the idea that all knowledge was sacred and therefore was to be valued and cared for. Only then could they be nourished with the sacred food of the kete of knowledge. As outlined earlier, the sessions were generally held during the relaxed periods of the year particularly during the winter months when the activities of fishing, hunting, harvesting and planting were over and the help of the students was not necessary. Normally, learning was a life-long search, and even after graduation most of the members continued to attend waananga.

At the time of graduation, the tauira were required to undertake some searching tests. Those devoted to Taanemahuta were, for example, ordered to go to the forest with no food provisions, sometimes for quite a few weeks and were expected to fend for themselves, living off the contribution provided by Taanemahuta. It was a period of arbitration and/or fasting in which they were not only expected to practice their bush craft, but also to learn to converse with the spirit of their tutelary divinity and return with some unique knowledge. Their graduation depended upon their passing the accurate tests and examination imposed by the wise members of the waananga. If they passed the tests, they were admitted into a new grade, or order of the taura (masters, teachers).

When a tauira graduated, he revisited the rear ridgepole where he took up the rehutai - the red coloured stone and emblematically swallowed it. These emblematic ritualistic actions brought home some important truths. When the tauira entered the waananga, the - hukatai - the white stone - was swallowed to acknowledge that the tauira was entering upon a search for knowledge known as Maatauranga. Knowledge and wisdom are linked but diverse in nature. Knowledge is an object in the head; it is a gathering of facts, whereas wisdom is an object of the heart and has its own thought processes. It is in the heart that knowledge is incorporated, for this is the centre of one's being.

\footnotetext{
${ }^{53} \mathrm{Katu}$ is the rituals, by which students are suspended in water to expand their capacity to hear, capture and remember the words of rituals, prayer and incantations. When this is finished the student returns to the House of Learning.
} 
Given the importance of understanding how Maaori view the world, the value placed on the acquisition of Maatauranga Maaori is vital to the continued existence of Maaori as a people. It is important to read and think around the kaupapa of such an undertaking. A significant part of this process is that unless we take this journey of exploration, we will fail to understand the significance or outcomes by Maaori envisaged as the result of such a change. The ability to understand the value of the customary Whare Waananga and its reasons for transmitting the knowledge contained within its confines, is important to this research study. All of this allows us as Maaori to locate, position and claim the idea that being Maaori is who we are is how we are, which the participants have conveyed in Chapters 4 and 5 through the disclosure of their whakapapa and life-stories.

\section{Summary of chapter}

To contribute to the understanding of the experiences of the six participants, it was important to explore customary kaupapa of Maatauranga Maaori and what they entailed. This included looking at all aspects associated with a Maaori worldview, which highlighted the value of the customary Whare Waananga that represent an integral, part of knowing about being Maaori. This then aligns itself with the idea that 'being Maaori' is 'what I do' is 'how I am', which will allow the kaupapa themes to emerge from the life-stories of the six participants identified in Chapter 5. These kaupapa associated with that particular section have been outlined in this chapter. The expectation of this research is that the exploration of these kaupapa by engaging with aspects of what this knowledge constitutes, and how this knowledge was transmitted and understood, would help position the six participants' whakapapa and life-stories. In the next chapter I will show the importance of having a framework, methodology, method and design suitable for this research study and the implication this has for the research questions outlined. 


\section{Chapter 3 Theoretical framework, methodology and design}

This chapter focuses on the framework, method and design implemented and applied in this research. It will be achieved by exploring the epistemological framework of Maatauranga Maaori. The method used to complete this is that of life-stories - oral stories. Maatauranga Maaori and life-stories - oral stories both relate to oral tikanga and kaupapa as a way of gathering stories and passing on knowledge, whether it is about aspects of Maaori life or nursing practice. There are other Maaori nurse researchers and educators who have included stories within their academic work: Holdaway, (2002), Mulligan, (2003); Nielson-Hornblow, (2004), and Wilson, (2005). Indigenous writers and researchers have life-stories - oral stories to relate (for example Bin-Sallik, 2005; Bull, 2005; Crier, 2005; Egudu, 1981; Huggins, R and Huggins, J, 1994; Leo, 2005; Silko, 1997, 1999; Standing Bear, 1988; Strickson-Pua, 2006; Tucker, 1977; and, Westerman, 2006), all of which support the value of life-stories - oral stories.

This research study has focused on the epistemology framework of Maatauranga Maaori. It will further the progress of the research questions being explored; namely What are Maaori registered nurses' understandings of Maatauranga Maaori in relationship to nursing practice? And, how do they apply these understandings in nursing practice? This is fundamental to the research study, because part of the consideration of the outcome will involve these questions, reflecting solutions.

Because the decision was made that Maatauranga Maaori be the epistemological framework the literature was explored further and writing began on this subject. It was important to be mindful that the oral understandings were paramount to this viewpoint. Maatauranga Maaori is a knowledge continuum that embeds itself in the customary views of Maaori tuupuna, but for the purpose of this research study a more contemporary position will be taken on this kaupapa, this being more relevant to the researcher's world and the worlds of the participants. It gives mana and mauri and allows rangatiratanga to be part of the six participants, their whaanau, hapuu and $i w i$, which allows the necessary knowledge to reside within them. These kaupapa are reflective of the subjective and holistic nature they are embedded in. It is on this basis that I can make the claim that this is the framework needed for this research study. There are also other Maaori academics 
who have positioned Maatauranga Maaori as an integral part of their research and education practice, (M. Durie, 2004; Irwin, 1992; Royal, 2004; J. Williams, 2000; L. Williams, 2004; W. Winiata, 2000 and, P. Winiata 2005). We are seeing a revival of this framework for the purpose of introducing it as a pathway forward for Maaori to consider within their research projects. I believe, as the researcher, this is because as a concept, it is by, for and about Maaori.

Kaupapa Maaori was briefly considered as a conceptual framework of choice, but it does not capture the overarching and holistic kaupapa of Maatauranga Maaori. Maureen Holdaway, a Maaori nurse academic used a Kaupapa Maaori framework for her doctoral thesis A Maaori model of primary health care nursing (Holdaway, 2002). Another was Denise Wilson (2004), whose doctoral thesis was entitled Ngaa Kairaranga Oranga: The weavers of health and wellbeing: A grounded theory study. Within their educational and academic practices, there are Maaori academics who have integrated Kaupapa Maaori within their writing, particularly the original writer Graham Smith (1997) and also Linda Smith (1999). There are also those who have been encouraged to write from this perspective (for example Churchward, 1991; Clareburt, 1992; Connor, 1995; Hohepa, 1990; Jenkins, 1991; Ka'ai, 1990 and, Port, 1995). Because kaupapa as a concept is inherent in Maatauranga Maaori these writings will contribute to the literature required for this study.

The work undertaken by the Human Rights and Equal Opportunity Commission (1997) in Australia is another insightful inquiry into the stories of Aboriginal children and the consequences of this action. The unique undertaking by Aboriginal nurses (Goold and Liddle, 2005) of writing their stories In our own right: Black Australian nurses' stories has contributed to the literature to reinforce the value of storytelling and storytellers.

An insightful article written by Roxanne Struthers and Cynthia Peden-McAlphine (2005), Phenomenological research among Canadian and United States indigenous populations: Oral traditions and quintessence of time, outlines the importance of oral customs and their value to Indigenous peoples. The article specified that oral stories regarding Indigenous peoples are a form of teaching and learning which is woven into all 
aspects of their lives and the foundation is established in oral traditions (Einhorn, 2000; Poupart, 2003; Struthers, 2001). Like Maaori (Nicholson, 2006), Indigenous people had little if any written record regarding their oratory way of life (Vanderwerth, 1971). Their speeches, prayers, stories and songs have been dependent on memory (Einhorn, 2000) and so too with Maaori. It was also embedded in their paintings, dance, carvings and their expressive body movements (Edmonds and Clark, 1989). The Native American culture believes that oral tradition portrays the culture (Poupart, 2003) and like Maaori (Marsden, 1997) believe it embeds their soul (Einhorn, 2000). As with Maaori, Indigenous people signal the significance of storytelling, storytellers and oral customs as inherent methods of relaying and discussing the past, the present and the future.

So that the reader of this section can gain insight into the structure of this study and the layout of the many threads that show my rationale for using Maatauranga Maaori as the epistemology framework and life stories - oral stories as the methodology, I will organise this section in the following way. In section one, I will explore: the contribution of thinking and writing that have influenced the introduction of Maatauranga Maaori as a framework; the role of the researcher from a Maatauranga Maaori continuum; life-stories as an inquiry; contribution of life-stories as a form of inquiry from a personal level and the inclusion of Charles Royal's view of stories from a Maatauranga Maaori continuum; usage of life-stories by Maaori nurses researchers; the doing or ontological position and the knowing about or epistemological viewpoint from a Maaori nurse researchers position; issues of methodological rigour; life-stories - oral stories and their application to this research study; the research design, seeking ethical approval and selecting the research participants.

Section two, conveys the research processes - that is how and why I went about the study. This will include: looking at the, beginning of the pathway with the six participants, usage of conversations, the question of the word $I$ and space; weaving as a holistic metaphor and its application to this research study; whakapapa a life-story framework for recommencing the participant's conversations; the process of gathering, analysing and interpreting the lifestories; writing the whakapapa story sections; the process or phase of creating the kaupapa themes; development of the kaupapa themes; the reflection on rigour and the emergence of criteria - those of reflexivity, trustworthiness, authenticity and credibility from a Maatauranga Maaori continuum. 


\section{Section 1 Introducing the framework for this study}

\section{Maatauranga Maaori as the framework for this research study}

To use Maatauranga Maaori as a framework was not a hard choice to make because I see it as a natural progression for me, as it has become an important part of my education and nursing practice since the 1970 s when I became involved in nursing as a profession. It has also been part of my upbringing as a child, adolescent and adult. The continual journey of discovery involved in gaining new knowledge made me realise how important it was to be true to being Maaori because it is an integral part of who I am and how I am. It is also, I believe, who these six participants are. I have and will be faced with challenges associated with such a stance, but this makes it even more important to pursue the acknowledgement needed for this kaupapa to be recognised as a research framework.

The essential understanding around this framework will be that of a contemporary position, as this is more relevant to my world and the worlds of the participants. As Charles Royal (2004) offers a similar stance, his work will contribute to this study. I felt there was a missing link in this research, because I was looking for a framework that was embedded in the way these six participants' whakapapa and life-stories needed to be positioned. Such a worldview would generate solutions to problems, and would use Maaori cultural preferences and practices, despite these being dramatically effected by colonisation ${ }^{54}$ (Bishop, 1996). This would not be an add-on worldview, which has dominated Maaori for the last one hundred and fifty years. It would instead be the worldview that is distinctively Maaori and that has been part of us since our inception as a people, but would also recognise the contemporary issues that have impacted on it.

It may be considered that it is unrealistic to create a Maatauranga Maaori framework from a contemporary position for the purpose of conducting research study. As with Charles Royal, I disagree. I believe it is possible to create a framework for Maaori to use if one

\footnotetext{
${ }^{54}$ Robert Yazzie (2000, p. 85) explains that "when one talks about colonisation in the modern world we are really talking about the conquest and control of non-white, non-European peoples. When we talk about colonies and colonialism, we are usually talking about the lands settled by Europeans following the arrival of Columbus in 1492. They include Canada and its Indigenous peoples, the United States and Indians, Indigenous Australia, Maaori Aotearoa, the native Pacific Islands, Indian Latin America, and Indigenous Africa". Yazzie is Navajo and the Chief Justice of the Navajo Nation. He has a law degree from the University of New Mexico and was appointed to the bench in 1986. He is a strong advocate of the sharing of traditional values and continues to implement the Navajo philosophy in the Navajo Nation courts.
} 
takes a broad view as to what Maatauranga Maaori is. Furthermore, it is possible to create such a framework, which allows the use of non-Maaori knowledge such as the sciences (Roberts and Wills, 1998) in this research. This allows the situating of this knowledge within the contemporary Whare Waananga to address critical issues around areas such as needs, concerns and aspirations of the Maaori community; developing Maatauranga Maaori and Whare Waananga performances. But first we need to ensure that the creation of this framework from a Maatauranga Maaori continuum is undertaken by Maaori themselves, which includes one's whaanau, hapuu and iwi.

Once this has been established, we can then proceed to explore and enhance Maatauranga Maaori as a framework. Achieving this allows Maatauranga Maaori to be included on the research agenda for contemporary Whare Waananga, which then establishes a research framework or programme that is not bound by outcomes. That is, the research topic is primarily about the development of knowledge. It allows for research to be exploratory, novel and experimental. Researchers in this space will be conducting what is called researcher initiated or blue sky research. This may include for example research into language, history, natural world, human behaviour, worldviews, tikanga, kaupapa, methodologies of knowledge inquiry, technology and many other topics. This is outlined by Hirini Meads (2003) who extends on this idea by saying Maatauranga Maaori will include whole collections of subjects that are common in contemporary society today such as education, philosophy, history, language, mathematics and so on but inclusive will be subjects we have never heard of.

What then are the key features needed in a contemporary Maatauranga Maaori framework? One might introduce the use of whakapapa to explain space and time. Whakapapa is the mechanism used by Maaori to establish whaanau relationships, with which one has unavoidable, bodily links (Bishop, 1996), as well as knowledge regarding mythology and the tuupuna who have now passed on. The oral and written format used would have entered into Maatauranga Maaori conversation with the use of te reo Maaori, and this can become another way in which to frame research from a Maatauranga Maaori continuum. Russell Bishop's (1996) discussion of whanaungatanga is a prime example of a kaupapa that should be recognised as a framework for research study, without having to endorse its acceptance by aligning it with Kaupapa Maaori. The kaupapa of tuurangawaewae, wairuatanga, manaakitanga and rangatiratanga are but some of the 
other kaupapa that contribute to being Maaori and are part of the development needed for the framing of one's research. These kaupapa embed us as Maaori in the holistic view we have of the world. If we are to make change for Maaori, it can only be done within the confines of our worldview and it is important to accept and embrace this collection of kaupapa that make Maaori people who they are. It became the predominant theme and focus throughout the six participants' whakapapa and life-stories.

There needs to be less disagreement and more of a focus on Maatauranga Maaori within its own space, which is often, but not always, within Maaori institutions, particularly the marae, and new Maaori educational centres such as the contemporary Whare Waananga. The principal example is the oral repository of Maatauranga, which is characterised by the work of Sir Aapirana Ngata and Doctor Pei Te Hurinui Jones ${ }^{55}$ who were renowned exponents in their field of Maaori knowledge. There needs to be an inclusion of Maaori who are repositories of knowledge, who perform functions in marae ritual, reciting whakapapa, original stories and who bring about whanaungatanga and other kaupapa outlined regarding Maatauranga Maaori throughout their work (Nicholson, 2003). The introduction of contemporary artists, writers, playwrights and poets to name but a few in the literary world of Maaori, will be part of this development (Whaitiri, 2006). Mention also needs to be made of the weavers, carvers and sculptors whose works are part of the storytelling about Maaori (Jahnke, 2006). The revitalisation of music, songs and dance has been undertaken by contemporary Maaori (Flintoff, 2005). There are those contemporary Maaori who are becoming exponents within the fields of science and technology that have started to write and research from a scientific perspective that highlights the importance of being Maaori (Roberts and Wills, 1998) and incorporates the ideas associated with being Maaori. This worldview can then become part of a framework to introduce into areas of research.

There are three recurring themes in the literature: paradigm, cosmological or mythological pictures and worldview. Thomas Kuhn (1962) in his writings on The Structure of Scientific Revolutions contends ... that scientist's work within and against the background of an unquestioned theory or set of beliefs, [is] something he characterises as a paradigm. Kuhn called these challenging conceptual foundations paradigms because they

\footnotetext{
${ }^{55}$ Known as Pei Te Hurinui Jones and of Ngaati Maniapoto iwi affiliation. He was also a 20th century Tainui scholar.
} 
included not only original speculation, but also systems of theories, principles and policies. Therefore, a paradigm shift transpires when scientists cannot make clear certain data or natural phenomena (often called transgressions) by reference to established scientific theories. As the scientific world takes an empirical stance to research, it would struggle to accept Maatauranga Maaori as a kaupapa, as it is a holistically driven research framework.

In his book on Maaori religion James Irwin (1984, p.5) discusses the notion of the cosmological or mythological picture by saying "mythology portrays an orientation to life and a way of accepting existence". These ideas give rise to the well-known notion that inquiry about the nature of the world, whoever the inquirer may be, is conducted within a framework of thought, values and insights in which their worldview is positioned. It is these thoughts that methodology is engaged within one's research. In order to establish the process or methodology (ies) by which Maatauranga Maaori has been created, one needs to discover the essential ideas of Maaori culture that gives rise to their worldview. A definition of this worldview is provided by Maaori Marsden (1992) where he contends the Maaori worldview lies at the very heart of their culture, which influences every aspect of their culture.

An important contribution to the development and understanding regarding Maatauranga Maaori is the role of the researcher in this research study in the way stories are gathered from the participants.

\section{Role of the researcher from a Maatauranga Maaori continuum}

It is important to reflect on how I as the researcher view my role within a Maatauranga Maaori continuum, because it has a bearing on the next sections. To achieve this I would like to acknowledge the use of Russell Bishop's (1996) work, which outlines the way in which the researcher's position can be viewed:

Weaving as a metaphor brings with it distinguishable attributes that capture the essence of the researcher. As a metaphor this is how I see the reflection of the researcher from a Maatauranga Maaori continuum. The researcher will be termed the weaver and the technique of weaving is the tikanga. The research approaches are those tikanga of narratives such as waiata, pakiwaitara, kauwha (an exhortation) and whitiwhiti korero 
(reciprocal dialogue). The research framework underlying the weaving is called the whakapapa; this provides the research project with a sense of direction. To the weaver, the worldview within which the weaving takes place is the whaariki. This weaving imagery speaks as a manner in which the researcher works within a Maatauranga Maaori framework for discussion.

This viewpoint allowed me as the researcher to be part of the research development in a way that reflects the worldview in which I am embedded, which is one of being Maaori. It is also, I believe, how these six participants view the role of the researcher because it is consistent with how they as Maaori view the world. The gathering of these whakapapa and life-stories (presented in Chapters 4 and 5) can then be undertaken in a way that reflects the worldview of both the participants and myself as the researcher within this research study.

What follows is the exploration of life-stories from the researcher's personal viewpoint, and includes the ontological doing and the epistemological knowing about position that I aspire to as a Maaori nurse researcher. This will be related to the work undertaken by Charles Royal (2000) on his interpreting Maatauranga Maaori in regards to storytelling. Before undertaking this, an overview of life-stories as an inquiry will be discussed.

\section{Life-stories as an inquiry}

When considering this as being of value to this thesis I had a moment of doubt, because in my mind I had to ensure it captured what it is I was trying to reveal. While engaged in this constant quest for literature that supported one's argument, I happened to read the work of Gordimer (1975) where she states that ... in a certain sense a writer is selected by his subject - his subject being the consciousness of his era. My own experience regarding the care given to my mother while dying of cancer within the public health system is one that was buried and still exists in my consciousness of my own period in time, and has partly influenced my decision to conduct this research study using life-stories. The oral and written literature endorses the use of life-stories at a personal level as a valid methodology in research studies. Further to this Gordimer (2006) contends that writing is always an 
exploration of self and the world beginning with one's sub-conscious. For me, this statement means that at a sub-conscious level the subject has selected the person.

My main thrust in using life-stories as an approach from a Maatauranga Maaori continuum is the fact that over the centuries we as Maaori women have used this as a mode of communication to disclose one's life lived over time. Telling of stories - life-stories - oral stories is the only way in which the reader can understand what and how these six participants' whakapapa and life-stories have impacted on their lives over time. The stories reveal a process of unravelling the authentic and holistic self of these participants. To understand more about this, I have included my own personal idea on stories and storytelling to support this strong stance taken by these six participants.

\section{The researcher's personal view on storytelling}

As a child, storytelling was a great part of my life and remains with me today - it is embedded in my heart and mind. Because of this, as a researcher, I have been unwilling to put stories or life-stories into publication because to convey both the experience and reality of the story would be difficult to achieve in written form. In reality, stories or life-stories are full of consequences. They are also flexible; they develop, alter, and adapt from teller to teller as well as from listener to listener. Indeed, the power of the story is often found in its flexibility and attentiveness to the needs of the listener and the situation (White, 1997). What I have found to be important about stories or life-stories is that they are not seen for their words, so much as for their subject matter or meaning. This is, particularly relevant from the point of view of the six participants, and myself as the researcher.

These stories serve several functions. First, they not only relate the facts about what happened, but also communicate something about us, our experiences, perceptions, and view of the world. Second, just as stories shape the way we perceive and interact with the world, and reveal essential aspects of ourselves, in the later years of life they help us recall the journey of our life, with all its trepidations and triumphs. Third, even when we are gone, our stories remain behind, just as it has with those tuupuna who have passed on. Fourth, it is the stories of mythology, tikanga, kaupapa and $i w i$ histories that give reality to who we are as Maari. Contained within these stories are reflections on life lived over time. How these reflections have guided our social behaviour within the way we view the world as Maaori, has enabled our survival as a people. Finally, as Maaori nurses we 
engage in storytelling in our professional capacity when reporting to health professionals about people we have cared for and it is through storytelling that this care is ongoing.

\section{Charles Royal's view of stories from a Maatauranga Maaori continuum}

Another viewpoint on storytelling from a Maatauranga Maaori continuum is that written by Royal (2000), which he explains in the following manner. A particular way in which storytelling has evolved for Maaori and how they are embedded in it is known as puuraakau ${ }^{56}$. There are not many statements or definitions on the nature of customary Maaori story forms, despite the large number arising from an oral culture. Hence, puuraakau is the term used for stories containing enduring and sophisticated explanations concerning the nature of reality and human conditions. A puuraakau is a story within which are contained models, ideas and viewpoints, which have or indicate consequences to the people who recite them. They contain what Mircea Eliade calls exemplary models ${ }^{57}$ concerning how the world came to be and how we might live within it. Puuraakau generally are not trivial stories, but rather contain such themes as the creation of the world, the creation of the human beings, and the deeds of the Gods, illustrious tuupuna and more. Because puuraakau refer to, and indeed conjure up, the spirits of illustrious forebears, puuraakau are considered sacred texts. They are kawa in themselves whose express purpose is to manifest divinities, tuupuna and whaanau in the consciousness of the storyteller and the listener.

To explore storytelling as a model from a Maatauranga Maaori continuum, we need to consider the totality of the work and the storyteller, not just the story recited. How is the story told? What is the context of the story? The type of language and, the body language and so on, are also matters one needs to consider. Stories are sometimes composites that come from various sources, and there may be two or three versions of the same story. The view Charles Royal takes is that extracting a single story in this way is like trying to sever

\footnotetext{
${ }^{56}$ Royal $(2000$, p. 10) has developed this view of puuraakau based upon its etymology. "The word puu stands for the very first shoot that appears out of a seed whilst in the ground and from which the entire raakau (tree), grows. The growth of any tree, in the customary worldview is equated with Taane who succeeded in separating earth and sky by which the world was created. Any activity that can be conceptualised around the growth of a tree and therefore Taane paradigmatic act, is considered to be an enterprise of the deepest significance, according to Maaori customary thinking. It is for this reason that Royal used puuraakau to stand for those stories within which are contained the Maaori world's deepest and most important perspective on the nature of the world and of the human conditions".

${ }^{57}$ Royal (2000, p.12) confers that the "Romanian historian of religions, Mircea Eliade, was fond of the expression exemplary models" hence it can be found throughout Eliade entire opus, for example in The Sacred and the Profane.
} 
part of a spider's web. One cannot do it cleanly or easily, particularly if stories are tied together through the use of whakapapa. As I maintain the momentum of exploring aspects of stories or life-stories, I have found that there are Maaori nurse educators and researchers who have identified the importance of stories or life-stories as part of their methodology of choice within their research studies.

\section{Usage of life-stories by Maaori nurse researchers}

To capture and present the life-stories of these various Maaori nurse researchers is important to this study as it positions the whakapapa and life-stories to be disclosed in Chapters 4 and 5 by the six participants. It creates awareness so that those reading this research study become comfortable and familiar with what being Maaori means for Maaori nurses. Without this disclosure we cannot make changes that are beneficial for Maaori, their whaanau, hapuu and $i w i$ within health care services.

The following section outlines Maaori registered nurses who have included stories or storytelling as part of their research and writings. This comes in many forms and ideas but it adds validity to the positioning of this research study.

The Master's thesis written by Becky Fox ${ }^{58}$ (1999) entitled The antenatal education

\section{needs of Maaori women (in the Tainui region) and implications for Midwifery}

practice reflects the stories of six independent and self-employed practitioners, who practice in the Tainui ${ }^{59}$ region, and forty-two Maaori women who attended the Waahi ${ }^{60}$ marae clinic. The study revealed that regardless of some commonalities, there were a number of inconsistencies between existing practices of midwives regarding antennal education, and beliefs of the Maaori women. Interestingly, both midwives and Maaori

\footnotetext{
${ }^{58}$ Known as Rebecca Audrey Fox and of Ngaati Porou and Ngaati Kahungunu iwi affiliation. As a Maaori woman, midwife and mother, Becky had a strong commitment to support the improved health status of Maaori women. She held a position as a midwifery tutor at Waikato Polytechnic and alongside Rose McEldowney established the first Maaori nurses school within this Polytechnic. She was also kaiawhina within Te Waananga o Raukawa and her knowledge of research regarding Maaori was second to none. Another important position she held was within Plunket. Since her untimely death, she has left a large void. Hopefully, one or some of those Maaori student nurses who were privileged to be part of her knowledge and skills will pick up the mantle and continue to pursue Becky's dream of the continual improvement of the health status of Maaori women in Aotearoa. She had two children namely Mahinarangi and Gordaina.

${ }^{59}$ Tainui refers to the iwi situated in the central part of the North Island. This is located on (Appendix 2) as numbers $7,8,9,10 \& 11$.

${ }^{60}$ Waahi is situated in the Waikato area and was the first marae to establish (in 1992), a marae-based health clinic.
} 
women acknowledged their concerns and awareness in relation to these variations. It is inferred by the researcher that the study also exposed some of the effects which colonisation ${ }^{61}$ has had on the birthing process for Maaori women.

Nani McClusky Masters thesis is entitled (2005) Ngaa wheako a tetahi nehi Maaori $i$ roto $i$ te kooti mo nga tuupapaku me pehea te whakapai? A Maaori nurse's experience in the coroner's court - how can it be better? It outlines the value of storytelling as part of her research methodology formula. More importantly, it seeks and gains answers to the research question posed, and allowed a process of healing to take place for her and those whaanau members who were part of this journey with her.

Estelle Mulligan's Masters thesis (2003) was entitled Tihei Mauri Ora the breath of life: The conceptualisation of Tihei Mauri Ora within a Bachelor of Midwifery programme. This thesis explores the inception of the midwifery programme for Maaori nursing students at Waikato Polytechnic. It involves the stories of a selected group of people who became main players in the development of this programme and is a remarkable journey, giving insight into the trials and tribulations they faced to ensure this vision came to fruition.

Cherene Neilson-Hornblow in her Masters thesis (2004) Three key elements: Mental health delivery towards Maaori reflects the personal story of a whaanau member. It reflects the journey this whaanau had to take in the mental health system alongside their whaanau member. Their thoughts, feelings, pain and joy were expressed in this insightful piece of work, which encourages other Maaori educators and researchers to start writing and using storytelling as a means of transmitting knowledge.

The ability to explore the value of stories or life-stories requires a person to allow their mind and heart to be part of such an undertaking. This will not be difficult to understand for most who are Maaori but it may become an issue for those with worldviews positioned differently. It is through this understanding one can grasp the importance of stories and life-stories from a Maatauranga Maaori continuum. To further enhance this development

\footnotetext{
${ }^{6 \mathrm{I}}$ Colonisation in this particular instance reflects the way in which forms of social interaction changed, which influenced the way in which we conducted our everyday affairs. This, included the way in which we viewed the process of birthing.
} 
the ontological and epistemological position from a Maaori nurse researcher position will be outlined.

\title{
The doing or ontological position from a Maaori nurse researchers position
}

The way in which I envisaged the value of the doing or ontological position from a Maaori nurse's point of view, had to be an authentic Maaori worldview. My thinking and reading around this had been predominately from a Western viewpoint. However, what it has made me realise is that the doing is actually embedded in my life-story - oral story as a woman, Maaori nurse and educator. It did not occur to me that I needed to respect the whakapapa and life-stories that would be conveyed by these six participants, because the kaupapa by which the ethics proposal for this study was constructed ensured this occurred. As Mason Durie (2005) contends:

Research is an intervention, one which can be invasive with negative outcomes for Maaori or collaborative with mutual benefits for researchers, participants and their communities. Universities are already, familiar with research conducted for the advancement of knowledge, but the step towards research conducted for the advancement of people will have to be conducted with even greater ethical consideration

\begin{abstract}
Also, the way in which I had been reared since childhood on how to respect the tikanga and kaupapa of our people was ingrained into my thinking. Each one of these participants focused on their life lived over time, the meaning it had for them and how it may influence the provision of care within nursing practice for our people. How I visualised my ontological position is that I see myself as embedded in my tikanga, kaupapa, whakapapa, whaanau, hapuu, and $i w i$ just as I believe these six participants see themselves similarly positioned. For me, it occurred with the introduction as a young child to the different stories one would hear when engaged in the many activities children are allowed to do, around adults on one's marae. My main memory of this is when I used to sit with the many weavers associated with my marae, and listen to their animated accounts of life and those generations of tuupuna now gone through the stories they told. It was also obvious in the weaving of the many different garments, tukutuku or whaariki, the patterns, portrayed
\end{abstract}


stories over time to the present generation. All played a part in my ontological position as a Maaori nurse.

I believe all living things, including physical and natural resources possess a mauri or life essence which is a view supported by people such as Mason Durie (1999) and Nani McClusky (2005) who contends that the distinction between living and non-living objects has become blurred because each has been afforded a spiritual existence, which complements their physical state. Nothing is lifeless.

As for these two authors, mauri is significant in my interaction within the world I live in, and equally important is the mana associated with it. Both mauri and mana are interlinked. For me this means that having mana as a kaupapa is vital, which in turn has a flow-on-effect that encourages the respect of others. I believe we are born with mauri but one needs to nourish, nurture and develop mana. Further to this, is the fact that the doing is part of me because of my current employment situation. Te Waananga o Raukawa becomes the laboratory or nursery in which I grow and become sustained through those many repositories of knowledge: the students, staff and kaiawhina involved in this tertiary institute.

\section{The knowing about or epistemological position from a Maaori nurse researchers position}

First, the oral accounts of the knowing about comes from the discussions held with Iwi Nicholson, who was introduced as a very young child to sit, observe and listen at many and varied hui held throughout the country, in order to gain and preserve this knowledge to ensure the survival of our people. It is through these oral sources that the life-stories of our whaanau, hapuu and iwi are acknowledged. Again, this may not be considered a valid way in which to position a research study of this dimension. However, the orally transmitted accounts go a long way towards embedding the life-stories of the six participants, as the pathway that shows the value of the oral sources regarding their own hapuu and iwi. How one makes the distinction between what is and what is not considered the correct method to construct research, or whether or not oral accounts are informative, is an example of the same process that marginalises certain groups of people whose worldview may be different. Does this mean they can comment on that which is not their own worldview? Foucault (1980) states that I deem that it is through the re-emergence of 
this low-ranking knowledge's, these unqualified, even directly disqualified knowledge's ... that criticism performs its work.

When sitting, observing and listening to the weavers as they worked with their many threads of harakeke and patterns, and told stories of our tuupuna and, of life lived over time, all added to the knowledge needed to engage in this study. The oral accounts recounted at a hui held at $\mathrm{Ngaatokowaru}$ allowed those repositories of knowledge to recall stories. When surrounded by the photos of passed tuupuna, tukutuku, whaariki and whakairo all of which were work performed by these hapuu members, the stories associated with these developments was at the forefront of their conversations.

Second, the small amount of literature written and preserved is the basis upon which I have been introduced to the epistemological knowing or theoretical position on whakapapa and life-stories regarding Maatauranga Maaori. The literary writings of people such as Patrica Grace, Heni Potiki, Reina Whaitiri and Witi Ihimaera place great emphasis on stories and storytelling. Brian Flintoff (2005) introduces the argument that musical instruments contain mythological accounts of stories. Cleave Barlow, Mason Durie, Hirini Meads, Charles Royal, Rachel Selby, Ranginui Walker and Whatarangi Winiata are all Maaori academics who use stories to highlight the importance of the survival of Maaori as a people. Biographies written by Broughton and Phillis inform people of stories involving their own whaanau members. There have also been story accounts written by Paakehaa writers such as Binney, King, Metge, Orbell, Patterson and, Snedden who have had extensive communication and ongoing relationships with various hapuu and iwi. All of these serve as important sources of literature presenting their views on the centrality of stories and life-stories in Maaori culture.

Reflection became a major part of my epistemological pathway as I engaged with reading about, thinking about and processing the concept of life-stories - oral stories as a research methodology. After reading the large array of literature written by different academics on the subject of reflection (for example, Aitkins and Murphy, 1993; Johns, 1995; Johns and Freshwater, 2005; Mezirow, 1991; Ruth-Sahd, 2003; Taylor, 2000 and, Wilkinson, 1999) I would note any insights from these writings into my whakapapa story journal for future reference. I then started to become accustomed to understanding the difference between reflecting on these stories, life-stories and life histories from a Western position compared 
to a Maatauranga Maaori continuum. This would not have occurred if my thinking and reading had not been challenged by this research study. Because of the small amount of literature written from a Maatauranga Maaori continuum, the ability to make a distinction between these different viewpoints was limited. But based on my personal and academic experience, and the repositories of knowledge that I was able to access, and my own process of reflecting, I felt comfortable in acknowledging these people within this study.

Another reason for considering whakapapa and life-stories to be the appropriate methodology and framework for this thesis is because I have not included other people's comments about the participants or their practices. I am defining the whakapapa and lifestories from their viewpoint and their voices. I believe these whakapapa and life-stories have been constant travelling companions to the six participants within their language and culture (Gudmundsdottir, 1995) and through this, provide a meaningful human experience for them as a means of expressing their thoughts contained to memory (Polkinghorne, 1988).

A further epistemological or theoretical stance that I wish to acknowledge in this research is the decision to encourage Maaori registered nurses to be participants. This was based on the fact that as the researcher, I identify as Maaori and have been involved with Maaori students and health professionals. I did not feel that it was appropriate to work with Paakehaa nurses and their life-stories because my interpretation of their lived experiences would be different from my perception as a Maaori nurse. Linda Smith (1999, p. 68) states that for Maaori women inquiry into "the educational past are often voyages into a terrain entirely shadowed by histories of colonisation".

What has been outlined thus far paves the way towards epistemological consideration of methodological rigour regarding the use of life-stories and the design of the research. All of which endorse the value of life-stories - oral stories as the bases to frame this study.

\section{Issues of methodological rigour}

In this section I engage with the issue of methodological rigour. There are so many points of view around the question of methodological rigour, one could spend much time pondering and debating what is meant by rigour within one's research study. A question that comes to mind is, How does one's study ensure that this is reflected? Mason (1996, p. 
6) contends "the researcher should take stock of their actions in the research process" and "subject this to the same critical scrutiny as the rest of the data".

There has been much debate regarding rigour in life-stories - oral stories, which link into narrative inquiry (Lincoln and Guba 1985, 1994, 2000). Lincoln and Guba's thinking aligns itself with the main nucleus of this work, that of an epistemology in qualitative research. In 1994 they argued that the criteria of credibility, transferability and dependability ensures rigour, but their latest writings use terms such as authenticity and trustworthiness (2000) within constructivist paradigms as indicating integrity or quality criteria. The criteria of transferability refers to the fact that the research findings need to have meanings for others in similar situations. The criteria of dependability is used to convey the process of establishing credibility within the research. Credibility refers to the accurate description of the aim of the project, the questions, selection of participants, methodology, method and interpretation, and the need to make explicit why certain decisions have been made (McEldowney, 2002). With regards to authenticity, this has been referred to by Gardner et al, 2001 as a difficult concept to define. It is very much part of the holistic self and how we present ourselves in the everyday world as both the participants and the researcher. I believe integrity plays a part in determining this as a criteria so the things we try have an effect in the world. Trustworthiness is whether or not any given research is methodologically sound (Okello, 2006). Reflexivity and congruence are criteria that refer to the need for the researcher to address how the research questions inform the methodology and vice versa. In this research study, the recording of life-stories as a methodology aligned with the research questions being asked, namely, What are Maaori registered nurses' understandings of Maatauranga Maaori in relationship to nursing practice? And, how do they apply these understandings in nursing practice?

Other criteria are validity and reliability. Polkinghorne (1988) states that in life-stories oral stories are a valid means to retain the ordinary meaning of being sustained and well grounded. I believe validity is accounted for when I return the participants transcribed conversations and email the original transcription without any editing being done. Reliability means "producing results that are believable and have the appearance of truth" (p. 161), which is part of the criteria for rigour. However, there are some such as Sandelowski (1993, p. 8) who suggest that it is important to recognise and soften our 
criteria of rigour "to include imagination, soulfulness, techniques and playfulness" that we associate with more artistic endeavours.

The proposition I would like to put forward is that kaupapa such as whakapapa, te reo Maaori, wairuatanga, manaakitanga, whanaungatanga and kootahitanga (which are just some that need to be considered) are a way forward to recognise the rigour needed in research studies. Maaori as a people have always had criteria for assessing whether a method is valid. The notation of taonga tuku iho, which are literally the treasures of our tuupuna. These taonga are the collected wisdom of ages. Established over a long period of time, they are the means with which to observe and direct our lives today and in the future. Within these taonga are the messages of tikanga and kaupapa that guide this process. These kaupapa are not random nor applied ad hoc, but are based on proven principles (Bishop, 1996). They can therefore be used as a means to ensure rigour. The kaupapa that are disclosed by the six participants in Chapters 4 and 5 play an important part in this recognition and as such should be critiqued for rigour from the worldview of being Maaori.

One could become so overwhelmed with the criteria offered that I have come to the conclusion there is no set recipe or formula to ensure rigour. A set of useful criteria, have been referred to, and to ensure validity within this study I have selected trustworthiness, reflexivity, authenticity and credibility. I will conduct further discussion on this as a kaupapa in section 2, where I will reflect on rigour from a Maatauranga Maaori continuum.

\section{Life-stories - oral stories and their application to this research study}

For the purpose of this research study the identifying of Maaori and Indigenous writers and researchers is the pathway taken to recognize life-stories - oral stories as the method of framing this study. There are a noticeable number of Indigenous writers and researchers who are producing articles endorsing oral stories (Crazy Bull, 1997; His Horse is Thunder and Gipp, 2003; Leander, 2001 and Standing Bear, 1988). In this context oral means that it is unwritten (Panford et 1, 2001) and the main mode of retaining is through memory, events, drawings, carving, weaving, dance and song. These Indigenous writers and researchers are saying that the oral traditions and stories associated with their people are a 
valuable means of validating how they view the world and the values and beliefs associated with this notion.

The array of Indigenous writers, creative artists and researchers have supported the use of life-stories, oral stories, storytelling and storytellers as being important to the understanding associated with their worldviews. Examples of this are Ainsley, (2005) Armstrong, (1998) Bataille and Sands, (1984) Behrendt, (2004, 2005) Driskill, (2005) Fee, (1997) Harjo, (2005) Huggins, (1994) Huron, (2005) Inyallie, (2005) Lundgren, (1995) Masikad, (2005) Moreton-Robinson, (2000) Nabokov, (2002) Nanton, (1995), Severin, (2005) Struthers, (2001), Tucker, (1977) and, Yazzie, (2000) who have all endorsed this viewpoint. One needs to note that the lens through which Maaori and Indigenous peoples view the world is through their values, beliefs and ideals associated with their worldview (Blaeser, 1996) and is from a holistic viewpoint. An aspect of significance is that there are those in the historical scientific community who have debated and challenged whether the usefulness of an objective criteria for scientific truth is valid (Freyerabend, 1975) and, if individual scientists can be completely objective (Campbell, 1979). The critical ability then, is to meld these life-stories - oral stories, so that they depict the essence contained, which in itself adds value by virtue of its inclusion, as a way in which to position one's research study.

\section{Research Design}

There is no academic literature written on whakapapa and life-stories regarding Maaori registered nurses' understandings of Maatauranga Maaori, or their views on applying these understandings in nursing practice. Conducting conversations with a small number of participants throughout Aotearoa who are Maaori registered women nurses was important to this study. This research study is designed to find answers that reflect a Maaori worldview, which can only be obtained through those who whakapapa as Maaori. These conversations will contribute to the body of literature needed for this study. It is part of the research design protocol to be used in this research study. Lincoln and Guba (1985, p. 68) believe that "the design stage of any qualitative research is crucial" as it unfolds the research progress "indicating the flexibility of this approach". Focusing on the whakapapa and life-stories of these participants allows the depth and richness of knowledge regarding Maatauranga Maaori to be understood and included within this study, particularly as the central framework for this approach. By sharing these stories, it is hoped that the 
knowledge and understanding gained will be prescribed and complete thereby ensuring that this is acknowledged when discussing the value of this as the appropriate framework for this research study. The use of whakapapa and life-stories will give the reader the option to investigate and critique the study under exploration. Dickelmann, (2001, p. 124) says "by the provision of explicate texts, experiences and practices are acknowledged" and what is offered "is the significant meaning of the experience from a critical interpretation".

The selection of participants is important to this research because their understanding of whakapapa, whanaungatanga, whaanau, hapuu and iwi affiliation will allow these kaupapa of Maatauranga Maaori to be part of the process. By engaging in these kaupapa belonging to a Maaori worldview and being Maaori registered nurses may indicate that this could be a risk, as the cohort group will be small, as well as my entry into their lives as a researcher, to allow these conversations to unfold. Before I undertake discussion on the selection process I will outline how I gained ethical approval to undertake this study.

\section{Seeking ethical approval for the research study}

In November 2004, I started the process of seeking ethical approval from the Public Ethics Committee of Midcentral Health, Manawatu. The process for ethical approval subsequently shifted and needed to be considered by the Victoria University of Wellington (VUW) Ethics Committee.

The ethics proposal outlined that conversations would be the means by which to gain information. The way this data would be gathered would be seen as an extension of whanaungatanga and manaakitanga and this will allow the depth and richness of the conversations to occur without restriction on time. The technique used is that of openended conversations, which allowed the participants to speak freely, and to give answers in a manner that was appropriate to them, as factual information, in a question and answer format, or through the use of stories (Walsh-Tapiata, 1997). As Patton (1990, p. 56) says "this data ... is, collected as open-ended narrative without attempting to fit activities or people's experience into pre-determined standardised categories such as the response choices that comprise typical questionnaires or tests".

In Chapter 1, a hui held at Ngaatokowaru marae the hapuu members were invited to consider the research study under consideration and to offer their thoughts and ideas on 
kaupapa that has relevance to their worldview as Maaori. This proved a fruitful exercise because as the conversations progressed, the stories that unfolded reinforced those views expressed by the six participants. It also ensured that what had been outlined in the ethical proposal regarding the hapuu endorsement had been undertaken. The conversations conducted with the hapuu had aspects that interlinked with the whakapapa and life-stories of the six participants.

In the ethics application for this research study, I as the researcher wanted it to be known that the participants would be known to me through whakapapa and whanaungatanga. As this is an oral/life history approach, the participants were invited to name themselves if they chose, and they were also given the option to select what is written in the thesis in relation to their stories.

I have outlined what was included in the ethics proposal application regarding the kaupapa that guides the process from a Maaori worldview. These are whakapapa, te reo Maaori, manaakitanga, wairuatanga, whanaungatanga, rangatiratanga, kootahitanga, kaitiakitanga and uukaipootanga. As kaupapa they will ensure that the aspects are adhered to when the participants are engaging in storytelling and how these conversations will be analysed and interpreted. Approval was given (Appendix 3).

\section{Selecting participants for the research}

I did not have difficulty recruiting participants for this study and this is due to a variety of reasons. First, whakapapa plays a pivotal role in this process and is the generic blueprint, which allows us as a people to connect through whaanau, hapuu and iwi affiliation. It is through this concept that we are enabled, as Maaori registered nurses; to gain opportunities for dialogue and discuss in detail what will be undertaken in response to this study. Second, when whaanau and extended whaanau gather at one's marae for whatever reason, this allows information to be filtered out. In relation to this study, it provided a way in which to recruit participants. Third, hui (could be health or educational) held around the country that I attended allowed this information to be distributed far and wide. Finally, the understanding involving whanaungatanga or relationships determined how the process of recruiting these six participants progressed. Whanaungatanga allows the interactiveness of relationships to flow and it is through this kaupapa that the six participants availed themselves to be part of this study. Any form of relationship and the face to face or kanohi 
ki te kanohi ${ }^{62}$ dialogue allows whanaungatanga to be expressed. In some research approaches, the researcher may be seen as having power over the participants. However, when one acknowledges and exhibits the kaupapa that have been identified, this would eliminate any risk of this occurring.

The geographic location of the participants was not a problem because of the whakapapa and whanaungatanga concept. After reading the various opinions expressed by nurse educators and researchers (for example Harker, 2000; McEldowney, 2002 and, O'Reilly, 2002) I felt that six participants would be a good number. I also decided that having between one and five conversations with the six participants would generate ample data for the research study, and may take one to three days to be conducted. As it eventuated for these participants, four conversations were sufficient given the amount of data obtained, and also taking into account that each conversation took two hours or more. The introduction of the life-story framework made it easy to reconnect each new conversation with previous conversations held. Further into this chapter (section 2) the life-story framework will be explained. From a Paakehaa perspective these conversations may be viewed as an imposition on one's time but from a Maatauranga Maaori continuum this is known as whanaungatanga, and is important part of the research process for the participants and the researcher. If this needed to be extended, I then consulted the participants.

To help the process I decided to include the following profile on what these participants needed to contribute to this research study. The idea of using this concept of profiling for participants was due to work undertaken within my original proposal. The example of the profile follows (see Figure 4).

\footnotetext{
${ }^{62}$ Kanohi ki te kanohi or face-to-face discussion is most important when wanting consent for any research study by Maaori for Maaori. This is an opportunity to clearly outline the study to participants, orally and in writing, and to answer any questions that the participant may have. A number of Maaori writers use this type of process within their research because of the above attributes and more importantly, the development of whanaungatanga.
} 


\section{Profile of participant}

The participants would identify as Maaori registered women nurses who are currently in nursing practice

They would either be in psychiatric or comprehensive practice

They would have whakapapa affiliation and whanaungatanga connections

They would have the option to converse in te reo Maaori or English

They would have an understanding of the tikanga and kaupapa involving Maatauranga Maaori

Figure 4: Profile of participants

\section{Section 2 Research Process}

\section{The beginning of the pathway with the six participants}

As I mentioned earlier in section one, I needed to complete a profile of the potential participants and then plan on how I would gain the interests of participants. After actioning this plan, I waited for interest to be forthcoming. Due to the concept of whakapapa and whanaungatanga, this was a smooth process. Once I started to receive inquiries I contacted and conversed with the prospective participants. I then sent them a copy of the information sheet to be read and absorbed so that they could then finally make a decision whether to participant or not. When this was decided, I met with the participants and went through the whole process thoroughly with each one and the signing of the forms as completed. At a later stage in the process when I had to start the initial conversations I knew my role as kaihautuu was not one I could maintain as well as do justice to this research study, so I took leave.

Those six participants I approached volunteered to become participants and they were clear they all wanted to be known by their given names not by pseudonyms: Kim, Ani, Te Ata Hineroa, Margaret and Aroha. I was asking these participants to consider the research question: What are Maaori registered nurses' understandings of Maatauranga Maaori in 
relationship to nursing practice? How do they apply these understandings in nursing practice? One of the participants said no one had ever asked her such a question, and this gave her an opportunity to reflect what this meant for her. Another indicated that pondering and debating this as a question and taking this journey together made her make life-changing decisions around where she wanted to be academically and practically. I endeavoured to be thorough throughout the whole process, leaving no stone unturned including clarifying my role as the researcher, and acquiring a transcriber who is Maaori and was known to the participants through whanaungatanga. Because kaitiakitanga as a concept was part of this understanding it allowed the participant's to feel safe in the knowledge that their stories were being respected and enhanced from this viewpoint. Further into this section I will outline the construction and use of the backdrop of whakapapa as a life-story framework to enter the field of inquiry and the process of gathering the stories.

I undertook at the first initial meeting to explain the process and documentation involved in informed consent and once this had been accomplished, the documents were duly signed at this meeting. At the end of the discussions I sent a letter to each participant, thanking them for their participation in the research study and all returned their signed copies.

The next part of the processes was setting up the conversations to allow for the initial discussions to take place. All lived in close geographic proximity, so to negotiate a time and place to meet was simple. What was not simple was getting participants to guarantee their committement to the time agreed upon, because some had heavy work loads that impacted on the time they had allocated to participate in this study. This resulted in last minute phone calls to cancel and reaffirm another date and time. Once this was determined, I developed a timetable and audiotape log for each participant. This became an invaluable tool for managing the number of conversations and keeping track of how many audiotapes were to be transcribed during the initial phase. I also noted the sound quality of the audiotapes and whether they needed re-recording. The introduction of a new, high quality voice recorder, which did not need checking, made recording and transcribing simple. It allowed for several options for ensuring authenticity of the conversations. It was possible to transfer the conversations to compact disk or send a copy to the participant and the transcriber directly by email. I also ensured that I used the 
audiotape system as a back up and was able to give the participants the original tape at the conclusion of the research.

To ensure that I was focused and the participants were comfortable within this research study I created a life-story framework using whakapapa as the backdrop. I also ensured that the questions and framework of potential story ideas that I wanted to focus on with the participants, were clearly outlined. This proved the most beneficial imagery to use throughout this study and once introduced became our constant companion. Before attempting to convey these stories, I need to outline how and why conversations were used, the usage of the word $\mathbf{I}$ and the space needed to conduct this research with the participants. Also I needed to explain the application of weaving as holistic metaphor within this research study.

\section{Conversations}

Considering conversations, as having validity in research was an issue, which didn't arise, in the scientific community until the early 1960s (Ten Have, 1999). This originated from the Sociology Department at the University of California, Berkeley, through the author Eving Goffman (Scheglogg, 1992). Goffman, a lecturer, had developed a unique personal style of sociological analysis, based on observations of people in interaction and hence initiated an interesting area of research for his students - the area of direct face-to-face communication. This was later called interaction order (Goffman, 1983). This area of interest was further developed by Harold Garfinkel (1967) as a specific style of social analysis. This was the beginning of conversations being recognised as a valid means of conducting research within the science world. Besides sociology this means of communication has now been accepted by anthropologists, communication scientists, linguistics, educationalists and psychologists (Csak, 2002; Damico, et 1, 1999; Dow, 1994; Heritage, 1995; McEldowney, 2002; Slacks, 1984 and, Wootton, 1989).

A conversational approach, spoken or written, with its freedom and spaces, allows for reflexivity in this research and facilitates the development of the six participants and their whakapapa and life-stories. It allows and identifies in the text, a way in which my voice as the researcher can be included in the research. This is ideal as interviews would not be suitable for the way in which this research should be conducted - as the interview format does not align itself with the viewpoint being expressed. In research undertaken by Bishop 
and Glynn (1999) on the positioning of the word interview from a Maaori viewpoint, they contend researchers, in an endeavour to deal with their obligations, use interviews. However, entailed within this is the idea that interviews carry much cultural baggage and conjecture.

There is some constructive critiquing around interviews as a technique for researching, as this approach is very prescriptive in nature. This approach focuses on gathering data from an emotionally uninvolved participant who is lead through a series of questions by an unbiased researcher. Further to this Oakley $(1981$, p. 36) states that, as a model, it is "submissive and a mechanical tool of data collection". When this is used as a tool for research, its nature is one of rigidity and centres on a depersonalised method of questions and answers. As the researcher, the word conversation seemed more befitting the situation in which these six participants were disclosing their whakapapa and life-stories, so this was the mode by which these discussions would be conducted. Linda Smith (2001, p. 58) states that "Indigenous peoples, focus on conversation as part of storytelling".

Further to this I needed to ensure that the word conversations portrayed a Maaori worldview for these participants. To achieve this, the concept of whanaungatanga has been introduced so, as the researcher, I can evoke trust by developing relationships with these six participants to allow the flow of the conversations to predominate. I also aspire to make sure that the conversations and the stories being imparted are valued by all, and will not be treated in a way such that the mana and mauri of the participants and their lifestories are undervalued. The concern may be expressed that the nature of such conversations can also lead to bias, but by developing whanaungatanga with the participants, the conversations will be validated and diminish the possibility of bias. In the research project undertaken by Wheturangi Welsh-Tapiata ${ }^{63}$ (1997) these types of openended conversations were conducted, which allowed the worldview of the participants to be reflected. The value of this was evident with the amount of information being given and the way in which the participants felt at ease, knowing that the researcher and participants were connected with invisible links of respect and trust. In this research project the amount of data obtained also follows from this form of trust with the six participants, because of the manner in which the conversations were conducted. Conversations became

\footnotetext{
${ }^{63}$ Known as Wheturangi Welsh-Tapiata and of Ngaati Raukawa iwi affiliation. Welsh-Tapiata holds graduate qualifications from Massey University, Palmerston North, Aotearoa.
} 
the mode by which kanohi ki te kanohi interactions were undertaken and is the indicator on which method to use, as being more congruent to a Maaori worldview.

Another factor impacting on this research study is the concept of the word I or self, and how as a concept this plays a part in understanding the worldview of Maaori. Because the academic requirements of the University are to include the word $\mathbf{I}$ as part of the thesis format, the way in which this links to self is evident. It is important to explore this aspect because it has a particular implication for me as the researcher, and also impacts on the manner in which these conversations progress.

\section{Self or I}

When posed with this as part of my research study, I had difficulty complying with the use of the word I in my work, because my stance is one of whanaungatanga or the collective, not as an individual. This becomes a central theme when developing the kaupapa needed to acknowledge the life-stories of these six participants within Chapter 4 and 5 . The knowledge I have being given and the literature from Maaori being sourced belongs to the whaanau, hapuu and iwi. To express myself in a way that focuses on the individual and suggest that all that has been considered in this study, results solely from my own work, is an idea I cannot endorse. We only need to consider the research questions being asked; What are Maaori registered nurses' understandings of Maatauranga Maaori in relationship to nursing practice? And, how do they apply these understandings in nursing practice? The answers would come from the six participants who form a huge part of this research study, and who in turn would be reflecting and referring to the knowledge given to them by their whaanau, hapuu and $i w i$ as well as their personal experiences over time.

The view Myra Szasy (1986, p. 249) has on the word I is profound and she contends "I had a collective mind, seldom ever individual" and as such I would always acknowledge those whaanau, hapuu and iwi members who were part of this understanding. This is expressed in Virgina Myers (1986) and gives insight and deeper understanding into what it is Szasy is endeavouring to explain around the concept of the word I. Linda Smith (1994) expands further on this by saying ... the use of pronouns such as I can cause difficulties when writing for academic audiences, because while it maybe acceptable now in academic writing, it is not acceptable to Indigenous audiences. 
Maaori researchers and writers need to continue to debate and challenge around the usage of the word $\mathbf{I}$. This will ensure how we view this concept from a Maatauranga Maaori continuum is endorsed within academic writing and research. To achieve a level of understanding of what is to be disclosed by the participants requires the appropriate space for these conversations to be conducted. This includes the space to reflect, create and capture what these six participants wish to be discussed and accomplished, particularly regarding the research questions under consideration.

\section{Space}

This was not a hard decision for me to consider, as the six participants and I were of the same view that they should choose the space/place, time and day for the conversations to be held. A space indicated was their homes, which is acceptable as a place to conduct these conversations. Mihimihi and karakia were performed and kai was consumed by those who wanted to do this. In whatever situation we are in we adapt to the moment without any restrictions placed on each other. Because the participants determined the process to be involved it is the reason why these conversations had a duration period of up to four to five hours and extended over two or three days. It was important these participants were not rushed and they determined how these conversations were conducted and the time span in which they were to occur. Paakehaa may consider this an intrusion on their time, but Maaori consider that manaakitanga and whanaungatanga are being practiced and reciprocated.

\section{Weaving as a holistic metaphor and its application to this research study}

The use of weaving as a holistic metaphor arose from academic work that I have undertaken previously, as well as the personal interest I have in it as a creative pursuit. Like most Maaori researchers, I have used the holistic metaphor of weaving to describe and bring together the parts of a whole, the warp and the weft, to construct a new form, decipher problems, make sense of the world, and use language preferred by Maaori as a people (Bishop, 1996). The use of the language of a weaver as a holistic metaphor allows me to speak in the way in which I as the researcher have worked within a Maatauranga Maaori epistemological framework. It allows the conversations conducted with the six participants to be expressed and understood, and acknowledges their voices as paramount in this study. Inclusive will be their whaanau, hapuu and $i w i$. This may include the use of metaphors that may not be specifically related to weaving, but present some form of 
holistic metaphor that we as Maaori are familiar with. As I have indicated at the beginning of this study, I will endeavour to weave work with its many threads to make sense of this research study. This work has a general pattern, the specific construction varies from weaver to weaver, and this variation shows the distinctiveness of each artist. Similarly, in the whakapapa and life-stories of the participants, they show both similarities and differences, which highlight the uniqueness of the stories they unfold. Weaving and what it means from a Maaori worldview allows me to position this study in a way that represents and informs the reader that the language used is one that identifies being Maaori, and should be interpreted from this viewpoint.

An important aspect to be considered regarding the word weaving is that it needs to be demystified so that Maaori registered nurses are encouraged to use it within their research studies. Iwi Nicholson, (2006) supports and contributes to this understanding. Weaving in all its forms of what is generally described as Maaori customary art is a means of maintaining and perpetuating knowledge. Every design used in the weaving of kete, whaariki, piupiu (a garment), whatu kaakahu (woven cloak) and tukutuku, while they are objects that are aesthetically pleasing to the eye, were not created simply for their aesthetic contribution to the object or objects, which they sometimes adorn. It contributed to the completed object, maintaining the knowledge and values embodied in their design and manufacture.

The contribution to the health and wellbeing of Maaori is depicted through these various art forms and to gain understanding around this, the customary and contemporary weaving patterns used in tukutuku, which can be seen in wharenui throughout the land will contribute to this knowledge base. To begin with we will explore some of the customary applications. Poutama (stairway like pattern), which has many functions and interpretations and depicts the levels of customary Maaori society within whaanau, hapuu and $i w i$. First, this being the level of attainment within the customary schools of learning, producing experts in a range of disciplines. Second, the levels of seniority. Third, the levels of scholarship.

Other customary applications include kaokao, which in this context symbolises and reminds us that we all have a responsibility to care for one another. Paatikitiki (often described as the flounder pattern), which is related to food and depicts manaakitangata, hospitality and 
generosity and the need to practice the exercise of these values to the best of our ability. It recaps the need to protect our resources from unnecessary depletion or abuse. We must always be prepared to provide food and shelter for our guests or visitors, which will at times mean we have to deny ourselves. These are three examples of the customary application of tukutuku panels but there are many more and they serve the same purpose. They contribute to the health and wellbeing of the whaanau, hapuu and $i w i$.

A more contemporary viewpoint is illustrated below. The tukutuku ${ }^{64}$ panel featured (Figure 5) is a contemporary version that adorns the wall of Ngaatokowaru marae. There are numerous examples to be found within whaanau, hapuu and iwi throughout Aotearoa for which they have been created, but all have been embodied with the same tikanga and kaupapa mentioned. On reflection it is envisaged that this will be the start of Maaori registered nurses continuing the advancement of such knowledge for the health and wellbeing of Maaori as a people.

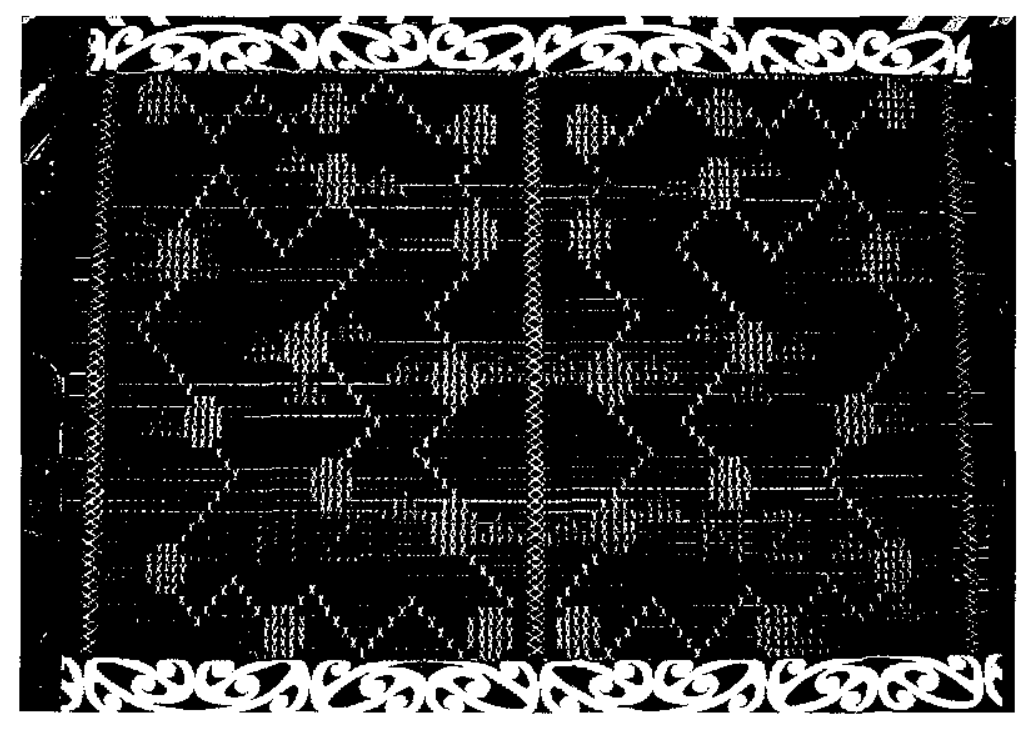

Figure 5: Tukutuku panel (Photography belonging to the researcher)

To allow for the reconnecting, refocusing or re-engaging with the conversations when time had lapsed between visits, I developed a framework, which would allow this to occur.

\footnotetext{
${ }^{64}$ Iwi Nicholson (2006) states Figure 5, is an example of such a contemporary pattern, recording the story of a woman of status who became the focus of ridicule and slanderous gossip. It may be expected that she would be quite depressed and custom demanded that she respond with a public statement to shed her depression and restore her standing as a person of status, not only within her own $i w i$ but in the wider Maaori world. She responded in song known as a paatere. The pattern depicts the places of importance and people of importance who reside at these places to whom she could claim close relationships to.
} 
This framework reconnected the conversations with the six participants across time, as did the use of whakapapa as a backdrop.

\section{Whakapapa a life-story framework for recommencing the participant's conversations}

The next section of this development involves the construction of a framework using the backdrop of whakapapa, which will consist of two series of research questions. The first series of conversations are the whakapapa stories of the six participants, which outlines their backgrounds, how they became a nurse, events/reforms which may have influenced them and, their worldview. The second series includes the research questions of this study, namely, What are Maaori registered nurses' understandings of Maatauranga Maaori in relationship to nursing practice? And, how do they apply these understandings in nursing practice? We can engage with the life-stories that unfold from these discussions to form the bases by which the participant's kaupapa themes will be produced.

As I became accustomed to this framework and the process of exploring the environment in relation to the research questions outlined, I needed to include this in the life-story framework I had constructed. First, I needed to revisit the questions being asked of the six participants. Second, it was important that these questions give voice to the life-stories of the participants and that I maintained this focus when designing the framework. What emerged from Chapters 4 and 5 is how paramount the voices were of the participants to uncover the answers to the research questions posed in the study.

In the process of constructing a life-story framework, the work designed by Rose McEldowney (2002) was the key that unlocked the way to construct this model. Therefore, it seemed a natural progression after gaining insight from the work produced by McEldowney, for the backdrop to be constructed from a whakapapa viewpoint. The title of the life-story framework became known as Reflecting and recreating the uukaipootanga for the recommencement of the conversations (Figure 6). This became the central way of reconnecting when we needed to refocus on the conversations and revisit any other points that may not been mentioned for whatever reason. Conversations became the terminology used and one, which the participants felt comfortable with when engaging or re-engaging with our research questions. It then was used as a point for establishing the focus of the life-stories. I framed these conversations in two parts with a break in-between each allowing a recounting of the kaupapa, just as one would construct within the linking of 
whakapapa lineage. Within the second part the research questions were woven into the story data. Before doing this, I needed to establish

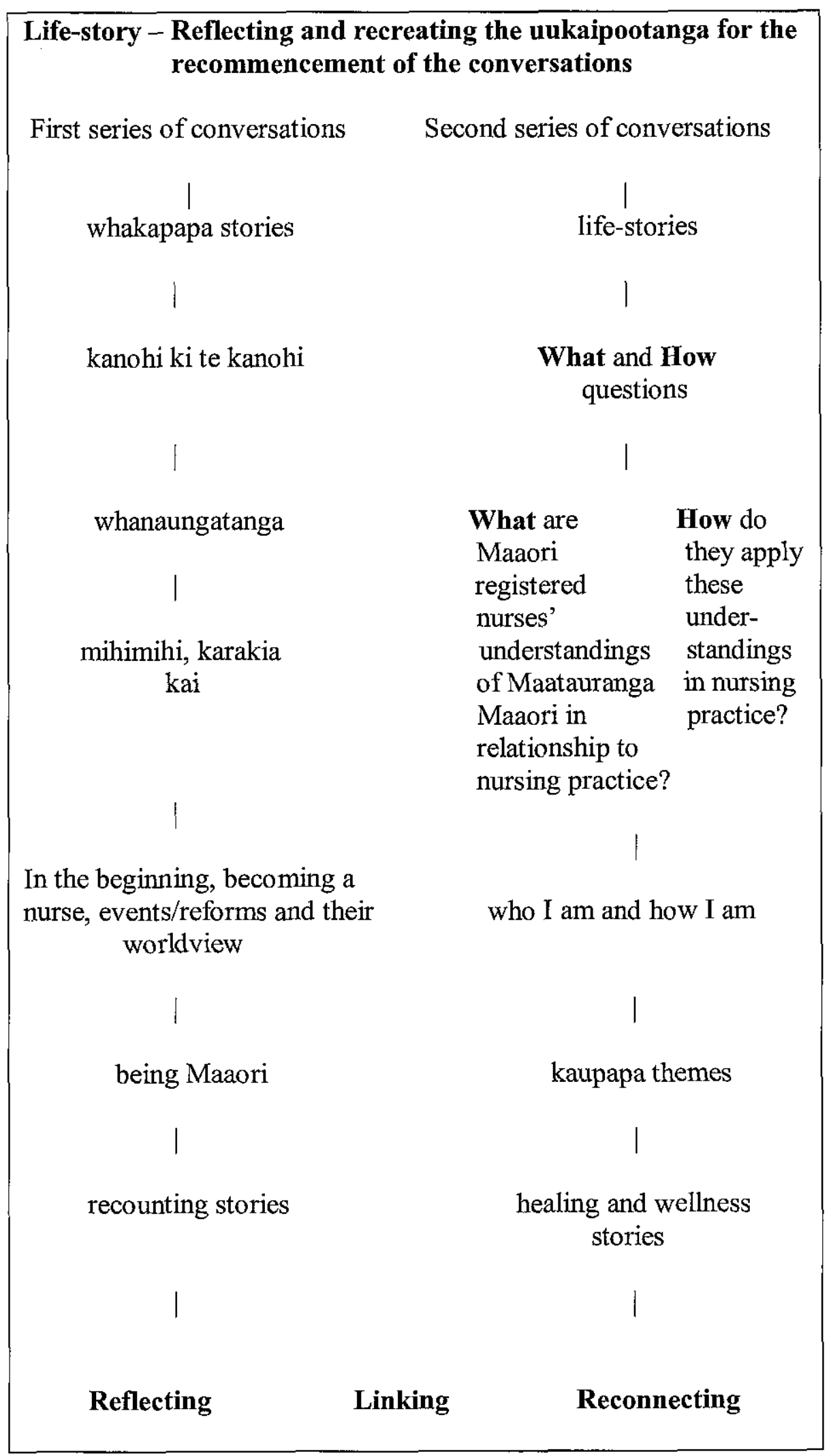

Figure 6: Life-story framework 
and understand the key points on the whakapapa stories so I could illustrate this in the lifestory framework as outlined earlier. These whakapapa stories will be represented in Chapter 4 as a way of backgrounding the participants. Once this had been recognized, we can move onto the research questions. The sharing of these whakapapa stories allowed whanaungatanga to be expressed between the participants and myself as the researcher, and this resulted in a sense of reciprocity between both parties. During this phase, the participants would at times in the discussions remember more detail around their experiences or events that had been part of their life, and we would return back to this at their direction. They would also in following conversations reaffirm what they had disclosed in previous conversations.

Another noticeable feature of the conversations was the interlinking and interconnecting of a collection of kaupapa that were starting to emerge from their life-stories. This added I believe to the overall congruence of the life-stories. The proposed story facts outlined in the life-story framework were there to provide a focus for the participants to reflect on the key research questions. They were not rigorously set, but open to analysis and discussion. In the first series of the conversations, the whakapapa stories focused on their lives lived over time and the influences that had affected them, including events, people and the participant's worldview. But in the second series of the conversations the what and how question were the main focus of our attention. In regards to the first question, I wanted the participants to consider what their understanding of Maatauranga Maaori was in relationship to nursing practice. Did it mean a mixing of the two worldviews, Paakehaa and Maaori? Or did it mean just a Maaori worldview on its own which incorporated the kaupapa associated with this view? Did this mean that the two worlds with each knowledge base were combined in partnership? Did it mean one worldview was more dominant then the other? Did they have stories to relate in both their personal or professional capacity that may have some relationship to this research question? Are these stories embedded in a Maatauranga Maaori continuum? In relation to the how question, I wanted to explore how they viewed these influences within nursing practice. I wanted to seek the wairuatanga or essence of how these participants expressed their experiences through the stories as lived stories. There may be myths or stories interwoven into the kaupapa of the participants that at times cannot be distinguished due to those elements that cannot be pulled apart but are mutually inclusive of each other. This then makes it difficult 
to have a clear cut process, in which to determine which stories or kaupapa themes were recognised, which meant there were a collection of kaupapa that may emerge.

Another way of focusing on this second series of conversations is on the healing and wellness stories, which by chance, may bring a sense of closure to the process for the participants themselves. However, it was also a way of leaving the portal open for future possibilities if no closure was reached, as there was only time to pause for a brief moment before resuming the journey of exploration into the research questions being asked. This is what the emergence of Maatauranga Maaori allows, forever evolving and forever changing with each generation. This may seem one of those illogical comments that I believe we as Maaori are known to say, but it allows for our space in which we can stop and contemplate our healing and wellness. It allows us to contemplate what might have been, could be or what should be reflected on, and includes moments of going down memory lane in relation to this journey. In a sense, the opportunities of whanaungatanga that arose in the process of the sharing the healing and wellness stories created a uukaipootanga space and place along the way to have a break and relax. It allows the reconnection back with one's wairuatanga that we as Maaori experience when in situations such as this.

The final phase of this life-story framework was the illogical process of the healing and wellness stories that would be attempted. It is reflected in the linking and reconnecting phase, which introduces the healing, and wellness stories to be considered. When considering this viewpoint, the hui conducted at Ngaatokowaru marae by hapuu members reinforced the feeling that healing and wellness can be an approach that Maaori can embrace, because over time this has proved to be a means by which harmony can be achieved when issues have became fraught with difficulties. This was demonstrated through the practice of arranged marriages. These unions functioned to avoid the harm that may have befallen hapuu and $i w i$ when they fought each other, and ensured harmony was maintained through whakapapa connections being established and children produced from these unions. To not dismiss such thoughts as illogical has been a means by which our tuupuna ensured that our survival as a people was paramount.

As I have mentioned, key kaupapa guided the development of the framework and allowed the study to unfold in a way that is applicable to these participants. Exploring the understanding of Maatauranga Maaori allowed these life-stories to unfold from the 
participants experience and acknowledged that there are specific stories in relationship to them, which needs to be understood. The idea was to ask them to consider those mythological, tikanga, kaupapa, whaanau, hapuu and iwi stories and then position them in a way that reflected their worldview. It created a space by which they could re-evaluate the kaupapa, if they so wished. The backdrop for the life-story framework came from the exploration of whakapapa. At some point within the conversations, the life-story framework was our guide, and was used to refocus or reaffirm one's direction or cover any other aspects the participants wished to include in the conversations. The final aspect is that this approach allowed me to pause and check with the participants on whether to proceed with the life-story framework. This also created space for illogical process of healing or wellness to be established. It allowed the fundamental process of reflecting, linking and reconnecting to be carried out.

This was to ensure that the participants understood the processes and allowed us to engage in a way that was mana enhancing. It also encouraged reciprocity and the critiquing of the what and how questions regarding the influence of Maatauranga Maaori in nursing practice. The reciprocal nature of the life-story framework facilitates, the achievement of the desired outcomes of this study. I could achieve these by reflecting on the conversations recorded on audiotapes or voice recorder, taking notes on key views and following these up when we next meet to allow the process of reconnection to begin again. Figure 6 shows this approach.

Further consideration is needed around other key contributions that assist in progressing Maatauranga Maaori as a framework. As mentioned earlier the value placed on the role of the researcher has importance as it impacts on the process of gathering the stories of these six participants, which will be outlined.

\section{Gathering the stories from the participants}

In Section 1 of this chapter, the role of the researcher played an important part in the gathering of the stories with the six participants. This took place during 2005 and 2006. Orchestrating and organising the date, time, place for the conversations needed to be negotiated with the participants. Before I began the conversations and while waiting for ethics approval, I gave some thought to how this development may proceed with the use of this particular framework. The various writings I have read reflect the notion that this is a 
time-consuming exercise. What I believe will eventuate out of this study is the reaffirmation of the importance of designing and implementing a framework that is reflective of the six participants and their worldview. This has been undertaken by the application of whakapapa as a backdrop and the life-story framework which is on page 102 (Figure 6). It will provide the whanaungatanga needed to allow the reconnection and holding of ideas over time, particularly if the time needed to conduct these conversations extends over a long period.

Each of the participant's conversations have been audiotaped on two tape recorders - I use one for transcribing and will give one to the participants. I already suggested an option which is a positive move regarding the transcription being produced. These conversations have been audiotaped and transcribed, which will allow me to edit and check for clarity and accuracy. This is what we as Maaori consider whanaungatanga and this aligns itself with the understanding of Maatauranga Maaori. Each of the participants have received a copy of the audiotape after each conversation, as well as a typed version of the conversations for their consideration and comments.

I mentioned in my ethical application that each participant would be interviewed up to five times, but not all the participants had the same number of conversations nor did the conversations take the same amount of time. This detail was noted in the conversation log developed for this purpose. The length of the conversations depended on the time the participants had available and the time each conversation took to complete. Throughout these conversations a great deal of being Maaori was disclosed. The participants gave time and consideration to these conversations and indicated when they needed to conclude. Important to this whole research is the understanding that these participants did not want to be viewed as being exemplars as Maaori nurses, but wanted to make it possible for others to learn from their experiences and to speak out if they felt compelled, in regard to their views on Maatauranga Maaori and how a kaupapa can be situated within a nursing practice setting. The whakataukii e kore te kuumara e ki ake ki ia he maangaro (the kuumara does not announce it is tasty) still holds sway in Maaori society even in this contemporary world (Diamond, 2004).

At no time did I need to turn the audiotape off during conversations because of a participant feeling distressed when faced with painful recollections. Only one participant, when 
talking about her parents, particularly her father became tearful briefly, but she did not want the tape stopped because of this. All through these conversations the reverberation of laughter was the main highlight and emotional experience with these participants. It was at their discretion that the conversation concluded and another suitable time was organised.

One key approach I used to assist and engage the participants to re-connect with the research procedure and content over time, was to listen to the audiotapes or voice recordings and read the transcripts between conversations. This allowed me to analyse and interpret the content that these six participants had shared in conversation and to take key kaupapa into the next conversation. By sending emails from the original transcript allowed those comfortable with this technology to critique and comment on their conversations. By carrying these conversations across there was an opportunity for engaging and developing certain themes over time, which gave rise to the depth and quality of the conversations.

I had developed a life-story framework by using the backdrop of whakapapa so that the participants and I could re-engage in the conversations. Once I had explained to the participants what it was I was trying to achieve, this was not difficult to implement and it proved to be the most beneficial imagery required. Within the framework, both the wording used to identify the kaupapa being explored, and the what and how question (used as the focus), were found to be valuable tools. In the end the participants initiated the reconnecting, linking and reflecting needed to recommence these conversations when we met so it became very much part of the journey we were taking together. This, I believe, occurred because the worldview in which this research study was situated aligned itself with these participants. All of which indicates the importance of having a framework that reflects the worldview held by participants engaging in this type of research. When a participant feels comfortable and secure in a study that adopts research techniques on the same lines of the participant's worldview such as on this occasion, then the experience and flow of conversations is a positive one for the participant.

To ensure a true reflection of the conversations in the stories that I constructed, I revisited, refocused and re-wrote the stories to ensure that they would first, resonate with the six participants. Reflection on this part of the research has taught me to be patient and to stretch one's thinking and reading and take the initial steps to weave and then complete the 
weaving in a way that tells the story about what are Maaori registered nurses' understandings of Maatauranga Maaori in relationship to nursing practice? How do they apply these understandings in nursing practice? These particular threads of this whakapapa panel have revealed a treasure trove of literature and oral resources. For some people reflection is not a precedence but we need reflection as part of this process to achieve outcomes necessary for our survival as Maaori.

\section{Analysing and interpreting the life-stories}

Critical to any research are the questions around analysing and interpreting the participants' life-stories. When asked about the method/s of analysis at a recent $\mathrm{PhD}$ school I struggled to give an appropriate answer because I had not given this aspect much thought because of where my work was situated at that precise time. This situation prompted my journey into identifying the best way to achieve results appropriate to this research. What analysis could I apply to the claims being made about whose knowledge? In other words, how rigorous and validated was this research study. What analysis and interpretations would be given to these participants' whakapapa and life-stories?

Establishing the criteria and the appropriate analysis to apply to any research study is more than simply arguing that one particular methodology uses this form of test to validate reliability and another requires something else. The analysis and interpretation of data gathered around the participants' whakapapa and life-stories had to be done in a way that ensured that I, as the researcher, did justice to their stories. It was important that I ensured their voices were evident in the texts and I needed to ensure that my voice was evident without being biased in any way. The original formation of the design and research questions eventuated from stories $I$ as the researcher had been exposed to during my nursing practice. This could be interpreted as the researcher coming into the research with a predetermined understanding of the desired results and therefore, from a biased position. I had to ensure this did not occur and with these thoughts in mind, found the words of Hampton (1995) worthy of consideration, which indicated that readers think and take what is useful and leave the rest.

When reading around the aspects of analysis and interpretation, I noted that academic writers considered and indicated that their work contained many layers of problems due to the fact that it meant many things to many researchers (Lincoln and Guba, 2000). When 
faced with the question of methods of analysis and interpretation, in this research, I was still facing the same dilemma. On reading the life-stories written by Maaori and Indigenous academic writers of varying professions, a key point was that the voice of the participants were and needed to be re-presented in the text from their worldview. EtterLewis, (1991), Fisher (1988), Phillis (2001), Russell (1997) and, L. Smith (1999) endorse such a view.

The life-story framework I believe would then become an essential component of this research, allowing the re-focusing and reaffirming of the participants throughout the conversations on their life-stories, regarding the what and how questions being explored. These research questions would guide the process of analysing and interpreting the participants' life-stories. Questions answered were: how would I determine what the stories mean? What part of the texts outlined by the participants would I include? All of this is valuable to the research analysis and interpretation, which needs to be done in a manner that captures and achieves understanding. van Manen (1997) describes this as plausible insight and further contends that good interpretive inquiry has been achieved when it enables people to suddenly see something in a way that enriches our understanding of everyday experiences.

Maatauranga Maaori and its inherent kaupapa are important to this portion of the research as they set the foundation of analysing and interpreting these six participants' life-stories. By establishing this aspect of analysis and interpretation one allows for the linkage, engaging and commitment of all involved in this research. It then leads to the validation or rigour required in research. As Denzin and Lincoln (1994) state terms such as internal, logical construct, external validity, text-based data, trustworthiness, credibility, truth, relevance, coherence and plausibility are attempts to reauthorise text according to the authority in the given moment.

This begs the question, whose authority? To conceptualise the grounding of a text in the external, empirical world of another worldview, represents efforts to develop a set of transcendent rules and procedures outside any specific research study as outlined by Denzin and Lincoln (1994). A Maatauranga Maaori continuum promotes an epistemological version of validity, one where the authority of the text is as Bishop $(1996$, p. 65) contends that this is "established through a set of tikanga and kaupapa and its representation". Such 
an approach to validity locates the mana within Maaori tikanga and kaupapa, where what is acceptable and what is not acceptable research, is determined by the research participants, whaanau, hapuu and iwi regarding text/or processes.

To allow the analysing and interpreting of these six participants' life-stories will be the result of one arriving at a place of understanding. I believe what will be conveyed in the texts of these life-stories will demonstrate how the reader can choose how they analyse and interpret the text and voice, opening possibilities for different interpretations, depending on their worldview. This is demonstrated in the words expressed by van Manen (1997) earlier in this section regarding understanding and how to interpret and analyse, to achieve the criteria required in research studies.

I needed to decide how I would approach the way in which I would work with the primary and secondary data. Primary data being that of the whakapapa and life-story texts, secondary data which would include waiata, mihimihi, photographs and written documentation that the women had given me during the conversations. There were two ways to approach the development of the data. The first would be to construct the section of these whakapapa stories to allow a brief profile of the women's accounts over time. They would include an explanation of the six participant's lives with their whaanau, hapuu and $i w i$, their early beginnings, schooling experience, events/reforms that may have impacted, being a nurse and their worldview. The other approach is to ensure that the kaupapa themes that emerged from the conversations were interpreted well and these would be used to locate and position the research questions being asked, namely, What are Maaori registered nurses' understandings of Maatauranga Maaori within nursing practice? How do they apply these understandings in nursing practice?

\section{Writing the whakapapa story section}

The composition of the whakapapa story section would give rise to those whaanau, hapuu and $i w i$ members identified through whanaungatanga all of which embeds these participants in the way they view the world. It also reveals over time, the pathway, which these six participants took to enter into the world of nursing, and what obstacles if any they had to overcome before becoming a nurse. Who played a role in this insight to go into the profession of nursing? How did they continue to stay in the field of nursing and were they tested when caring for Maaori from a viewpoint that had trained them to think and be from 
a Western perspective? Did they cross the line when nursing from a worldview not of their making? All of this must have tested them while in nursing practice.

These whakapapa stories give an account of their lives of becoming a nurse, which relates their private and professional views and contributes to the background of what and how Maaori registered nurses' understandings of Maatauranga Maaori within nursing practice. The stories gave accounts of their lives over time. I was interested in their life over time, people of influence, becoming a nurse and their worldview. This process involved reading the transcripts from the first conversation and identifying key kaupapa related to these questions. Often they would say my kaumaatua influenced me ... or my mother had a profound effect on me ... or my kuia (old woman) was influential in my upbringing ... or I remember when my father...

After transcribing and viewing these key points, I constructed what I felt was a key statement made by the participants. (for example: being Maaori is who I am and this merges into how I am and to achieve this is the emergence of a collection of kaupapa namely whakapapa, whanaungatanga, te reo Maaori, tuurangawaewae, wairuatanga, manaakitanga and rangatiratanga). I then constructed each kaupapa theme. This then guided me to write the whakapapa and life-stories because the participants would refer to aspects that impacted on their lives lived over time, which included the what and how they viewed the influence of Maatauranga Maaori within their nursing practice. I would take sections that related to this as a concept and at times the same story may have been repeated over several conversations. This leant itself to the notion of correlation being visible in these stories and the sense that it provided evidence of truthfulness. I found these conversations would go back and forward in time and ideas. At times the participants would contemplate and then re-engage with their thoughts and continue their conversations. Or the participants indicated that could we continue these trains of thought in the next conversation's so as to give them time to think on this particular part of the question being asked. Another comment made was I do not feel I have done justice to the question being asked so I want to revisit this again at our next set of conversations. I could relate to the contexts of these participants because of being Maaori, having whakapapa connections, similar age group or I had trained as a Maaori nurse around the same time, being in a particular era determined what qualifications would be undertaken and the development of 
whanaungatanga and whakapapa. This, allowed consideration of aspects that would not normally be within a research project.

When the whakapapa stories had been written, I would read and re-read to allow for flow and sequence. Then I would edit and send the stories back to the participants for their comments and critiquing. Each participant had experiences, ideas or characteristics that captured them in a way, which lead to the creation of a particular whakapapa section, which reflected them, or those of their whaanau, hapuu or iwi. They also had key kaupapa that reflected them in a similar vein yet there were those aspects that were dissimilar. What became a key success in this exercise was the development of the life-story framework by the usage of whakapapa as a backdrop. This imagery allowed the participants to focus on what they had spoken about as we had constructed a box like formation showing these sections of there lives over time. It was an important tool in the success of the writing of the whakapapa stories and also to capturing the kaupapa themes that came out of the participants' conversations. This will be discussed more fully in Chapter 4 following the presentation of the six participants' whakapapa stories.

\section{The process or phase of creating kaupapa themes}

Using life-stories, which outline the emergence of story themes, and how they are positioned, transpire when writers and researchers create their own, re-present or recreate others works on processes or phases, is evident in the literature (McEldowney, 2002; Moustakas's, 1990). To unfold these six participants' thoughts to allow the analysing and interpreting process, I needed to produce an approach to validate this from a Maatauranga Maaori continum and this was proving difficult. This is due to the limited literature on this as a subject matter and the limit to which I could contribute. However, I continued with the backdrop of using the whakapapa imagery and captured these important moments, from the six Maaori registered nurses - asking what are Maaori registered nurses' understandings of Maatauranga Maaori in relationship to nursing practice, and, how did they apply these understandings in nursing practice? They spoke for themselves but included were their whaanau, hapuu and iwi as part of this thought process as anything they do includes the collective. It includes who they are as Maaori nurses and why they practice the way they do and what and how this occurs in their nursing practice. 


\section{Development of the kaupapa themes}

This was another phase in my writing, where sleepless nights and waking at odd hours became part of my natural environment. To achieve this development of the kaupapa themes, I needed to complete the whakapapa and life-stories to allow myself to concentration on the literature, accentuated by the re-reading of the conversations that had been transcribed.

I began to think and at times believed I was becoming a sleepwalker where I was sure I was writing down these key phrases or ideas that were beginning to surface, from the individual conversations, which were being produced as sections by the participants. At times I doubted my sanity in these instances because realistically what I was doing was making a mental note and then referring to this in my wakeful moments. I made a conscious decision that the developing of these kaupapa themes would be from a Maaori worldview and they would contain the elements needed to locate, position and claim being Maaori is who these participants are and what they do.

Following on from this, new questions were emerging to guide me, such as what ideas or story sections are positive or not so positive. Was there anything that was noteworthy? I noted that there were similarities but also the distinctiveness of each participant's texts, but it allowed the emergence of key kaupapa or phrases to surface from the conversations of the six participants. I would then ponder and debate over points and if I was happy would print off the transcribed comments as well as making recordings of these ideas, which contained the stories of each of the participant's conversations. I needed to do this so that when I engaged in conversation with my primary supervisor, Rose McEldowney it would allow the flow of conversation between us to help develop and understand how to interpret such kaupapa themes. When meeting, this became a very fruitful exercise and experience for me. Rose reminded me to be true to myself as a Maaori researcher and not be deterred by accepting the dominant worldview that has been encouraged within studies of this dimension. I valued those comments because my dilemma was obvious when I tried to fit or conform to a worldview that was not what these participants were endeavouring to reflect in their whakapapa and life-story conversations. Everyone, I believe, has these moments in his or her studies. 


\section{Reflection on rigour from a Maatauranga Maaori continuum}

To get this point clear in my mind, I had to reflect on what I had written regarding issues around rigour. When embarking on a research study of this dimension, my understanding around the importance of rigour and its reflection was limited, especially when ensuring congruence between the framework, methodology, method and interpretation development of life-stories. My continual reading and thinking on other work done on this subject including, for example, Clandinin and Connelly (2000), Hertz (1997), Martin, 2000; McAdams, (2006) and, McEldowney, (2002), enabled me to become familiar and comfortable with the context of the journey. I had outlined issues on rigour and life-story - oral stories previously, which highlighted a variety of criteria but for this study I will consider trustworthiness, authenticity, credibility and reflexivity. So how did I meet the criteria outlined from a Maatauranga Maaori continuum?

I will introduce these criteria by including comments using the Maaori worldview. Trustworthiness from a Maatauranga Maaori continuum is the respecting and acknowledging the six participants, their whaanau, hapuu and $i$ wi. Because the life-stories involved their people connected by whakapapa, then this ensures that what is being considered is known to their people, who, in turn had this conveyed to them at some time in their life by some form of transmission. With this comes the responsibility of treating this knowledge with respect and having the ability to ensure that trustworthiness has been maintained. The contribution I bring as the researcher is to ensure that when these lifestories are written they reflect the knowledge given by those six participants and their tuupuna and those of their whaanau, hapuu and iwi. This will maintain the trustworthiness expressed and demonstrated by me as the researcher.

This trustworthiness is also reflected in the fact that they as participants have been willing to participate in this research, give of their whakapapa and life-stories, knowing full well the challenges they would experience. They all want to be known by their names and not pseudonyms, which also expresses their trust in the researcher. They would determine what was to be revealed in the writing of these kaupapa in the section of their life-story themes in Chapter 5.

The authentic self as Maaori is an intangible theme that evades people because it is about the holistic self of a person, which includes the concepts of wairuatanga and 
whanaungatanga. So how can one ensure this criteria of rigour is met? Maaori researchers, who are familiar with the holistic self, have no problem when reflecting on how this applies within one's research study. If one has been embedded in the worldview of Maaori the whole construct of the holistic self, which reflects the interwoven concepts of wairuatanga and whanaungatanga, is one that is developed and taught to them since their inception. One method is by ensuring that the integrity of the participants is maintained throughout the development of this research. This is vital and can be achieved by acknowledging the individual whakapapa stories and by weaving these individual voices through the kaupapa themes - but also by being mindful that this is a collaborative and collective means of gathering these stories. It belongs to the whaanau, hapuu and iwi inclusive of those tuupuna now gone. By the kaupapa of wairuatanga and whanaungatanga the participants and I will work closely together in determining what is to be included in this section, creating the holistic self as being paramount because it is who we are as Maaori.

Reflexivity is described by Koch and Harrington (1998) as a way of signposting to readers what is going on in the research ... by ongoing self-appraisal and self-critique. Whereas Lincoln and Guba (2000, p. 183) contends that reflexivity "is a conscious experience of one-self as both respondent and inquirer" lending the notion that one can begin to know the self within the process of research. It also encompasses how the researcher positions their voice and that of the participants within this study. One of the aims was to give voice to the participants' life-stories. I am aware that I need to ensure their voices are heard, while being mindful that my voice is part of the analysis and interpretation because of the situating of life-story - oral stories. I ensured that the participants were aware of this when holding our first conversation on being participants in research. It allowed the kaupapa of rangatiratanga and kootahitanga to be recognised as we both worked in unison to ensure this occurred. In the analysis and interpreting the pathway I will show the readers how I determined and used the processes to work with all the pages of texts involved.

One other criteria I used for analysing and interpreting the writing of the whakapapa and life-stories was that of credibility. These whakapapa and life-stories become credible when $I$ as the researcher ensure that they have conveyed the events and stories as the participants intended. It then presents itself again when I need to ensure that their whakapapa and life-stories were true and belonged to the participants and those that read 
their stories. Another factor to be expressed is the extent to which the stories were open to be challenged by the participants and those who may read the many interpretations as criteria of reflexivity. I made it clear in my application for ethical approval that I would share the researcher's interpretation of their stories with the participants.

At the conclusion of each conversation and then the transcribing, the participants received a copy or a compact disk of each audiotaped conversation as well as an email of the original conversations. I sent them their individual whakapapa stories sections from Chapter 4 and a copy of Chapter 5 relating to the kaupapa theme being Maaori is how I am. It was important for them to receive a copy of Chapter 5 for critiquing, as this was the area where the kaupapa themes emerged from the participants' stories. I asked them to read over the comments on their whakapapa stories, the sections and kaupapa themes, to consider whether my interpretation of their stories was credible. Did they think these accounts of their conversations were true? All voiced that they were comfortable and happy with the composition of their views. Kim commented on one piece by saying did I mention that in the conversations?. Hineroa remarked I am happy for my story to be expressed in this way. Ani nodded and commented that she was comfortable with being portrayed in such a manner. Margaret was happy with her whakapapa story and looked forward to the next chapter. Aroha being the laid back person she is, nodded and said I'm fine with what is being written. Te Ata was conservative in her comments and this isn't unusual for her but she was happy with the results and progress on the work. She indicated by asking when we would resume our conversations.

\section{Summary of chapter}

In this chapter I have presented the theoretical framework, methodology, method and design used to underpin the research study and reach a conclusion. Because Maatauranga Maaori as a kaupapa is not new, only its introduction as a framework for this study is new, which then makes the sourcing of literature available on the title of the research, noticeably scarce. I have endeavoured to reflect oral stories that can be of value to this research due to the absence of written work, being available. I believe that the exploration of Maatauranga Maaori as the epistemological framework is warranted within this research as it allows all interlinking threads to be established and acknowledged, which has and will 
be part of the storytelling and storyteller's contribution of these six Maaori registered nurses. It then allows the foundation of this research to be embedded within a tikanga and kaupapa viewpoint and that of oral stories inclusive of the written application, which is what nurses do when engaging in storytelling.

The accounts of work written by those Maaori academics (for example Bishop, 1996; Selby, 1999; Whaitiri, 2006) acknowledge the fact that stories and storytelling is integral to the continued existence of Maaori as a people. Charles Royal (2004) and Whatarangi Winiata (2005) also contend that to ensure our continued existence as a people we need to write and think from a Maatauranga Maaori continuum that acknowledges our worldview. The hui conducted by my hapuu Ngaati Pareraukawa is also an important viewpoint to be considered when writing on one's stories, which link and identify the value of oral communication. I conclude as the researcher of this study from the literature being written by, about and for Maaori as being sufficient in depth and richness that the academic rigour is being met from a Maatauranga Maaori continuum. As a framework it allows and acknowledges the validity and credibility of life-stories - oral stories as being integral to the participants. It represents their worldview and how they analyse and interpret the understanding of the positioning of their voice and my voice as the researcher. All of these writers have clearly conveyed the value of undertaking research from a worldview applicable to the way in which they view the world. The design and backdrop of the lifestory framework, have clearly indicated the value of such a process within this research study.

The role in which the researcher is outlined from a Maatauranga Maaori continuum is important to the understanding of how the participants view this person. It allows these participants to be secure in the knowledge that what is being analysed and interpreted regarding them, is from a viewpoint that is central to them being Maaori. This becomes a pivotal contribution to this research study.

I have undertaken to establish the research purpose, literature search, focusing on the research questions and I applied and sought ethical approval, which was granted. This was written from a Maatauranga Maaori continuum and the concepts' underlining this aspect was accepted by the Victoria University of Wellington Ethics Committee. Outlined has been the research design and I have detailed how I selected the participants and how 
whanaungatanga and whakapapa was formed and its relationship to the research study under exploration. I have explained the gathering of the life-stories. Faced with the pages of texts from the participants and by engaging in the reflective process, rigour has been ensured. The development and use of the backdrop of whakapapa as the construct of the life-story framework has been the most valuable tool introduced to this study, and has allowed the reconnecting of the six participants to their conversations. The acceptance of the transcriber who is Maaori and is known through whanaungatanga and kaitiakitanga to the six participants was another important consideration to be undertaken and disclosed. It allowed the participants to be safe and secure in the knowledge that someone known through this was transcribing and hearing their stories.

These conversations with the participants will allow the emergence of important key kaupapa themes to become known, which will generate knowledge that will contribute to this research. The need to engage with understanding around the word space and the word I required to conduct these conversations was important. I have endeavoured to design a process which embeds these kaupapa themes from a Maatauranga Maaori continuum, which was challenging in itself.

Using the importance of weaving as a holistic metaphor was undertaken to ensure that it allowed the positioning of this study in a way that represents and informs the reader that the language used is one that identifies being Maaori and should be interpreted from this viewpoint. This will allow those six participants' whakapapa and life-stories to be at the forefront of this research study.

The use of life-stories - oral stories as the methodology has been widely recognised by Maaori nurse educators and researchers (McClusky, 2005; Mulligan's, 2003; NeilsonHornblow, 2004 and, Holdaway, 2002) and, Indigenous writers (Goold, 2005; His Horse is thunder and Gipp, 2003; Tucker, 1977; Sakej, 2000 and Silko, 1997, 1999) as a formula for conducting one's research, and the literature on this was accessible and vastly informative. Life-stories - oral stories align with the research aim; and allow an analysis and theory to be part of the everyday lives of the six participants and their practice; it is an in-depth process; and, it allows the voices of the participants to be paramount. 
The careful literature search into the framework, methodology, method and design suited to this research left me in no way hesitant to accept the fact that life-story - oral stories research captures the necessary academic rigour. Merging this with a Maatauranga Maaori continuum was undertaken and was validated by the conversations with the six participants and those repositories of knowledge known in the Maaori world for there oratory skills, as well as those small number of Maaori academics who have written on this subject. After exploring the literature on rigour and the notion of life-stories and selecting a variety of criteria to ensure validity is evident (for example, Clandinin and Connelly, 2000; Lincoln and Guba, 1985;) produced this as well as that of a personal nature within the recognition of those repositories of knowledge who contribute to this study with their oratory skills (Nicholson, 2005).

To contribute to the experiences of the six participants, I wanted to listen to the whakapapa and life-stories of these Maaori nurses so that I could disclose the what and how of Maatauranga Maaori and its influences within nursing practice. The expectation of this research is that by giving voice to their personal and professional lives it will make visible the kaupapa of their whakapapa and life-stories that impact on the caring for Maaori as a people. In the next chapter I will show how I went about making that happen. 


\section{Chapter 4 Weaving the whakapapa and life-stories of the six participants}

The overall aim of this research is to recognise and encourage answers to be forthcoming regarding the questions being asked, What are registered Maaori nurses' understandings of Maatauranga Maaori within nursing practice? And, how do they apply these understandings in nursing practice? Gathering and then weaving the whakapapa and lifestories of these six participants, allows this understanding to be gained. A natural part of what they do as Maaori nurses within their nursing practice involves aspects that are disclosed by these stories. It could be acknowledged that it gives insight into who they are as Maaori nurses and particularly how they see the significance of Maatauranga Maaori within their nursing practice.

The following piece of artwork has been created by a Maaori woman artist namely, Hinepuorangi Winiata ${ }^{65}$ with whakapapa connections to Ngaati Pareraukawa (Figure 7). The usage of this visual and woven application is to reflect the whakapapa and life-stories of these six participants that are to be disclosed.

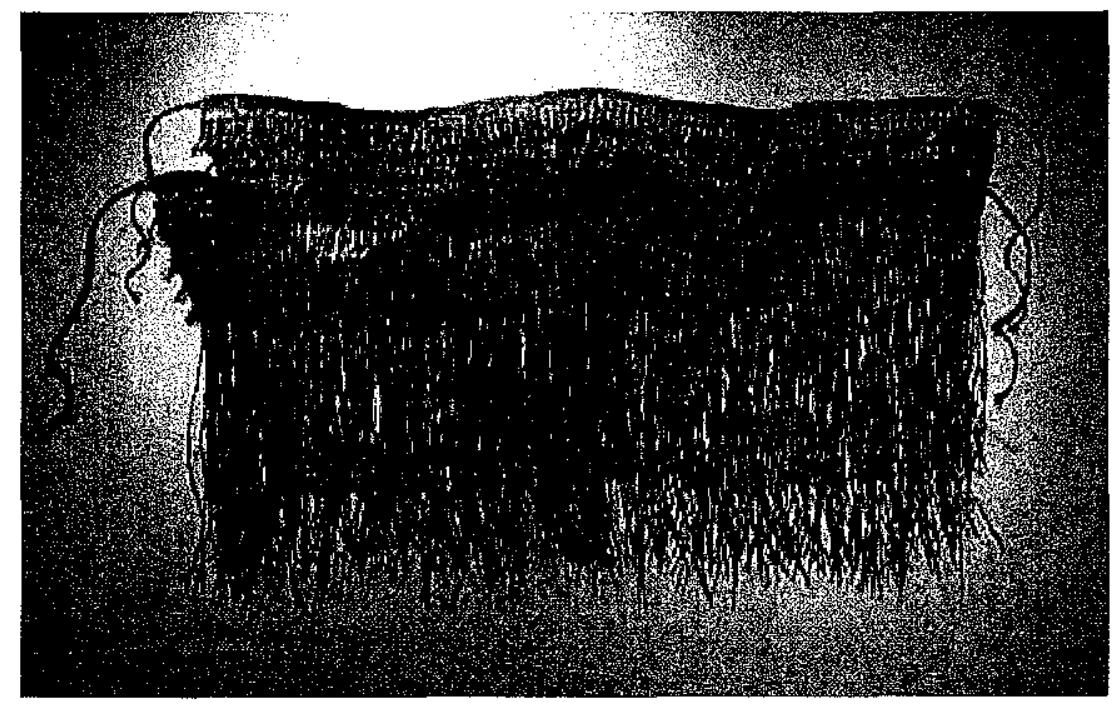

Figure 7: Whakapapa, whanaungatanga and kootahitanga (Photography belonging to Hinepuorangi Winiata)

\footnotetext{
${ }^{65}$ Known as Hinepuorangi Winiata of Ngaati Raukawa and Ngaati Tuukorehe iwi affiliation. She holds qualifications in Design and Art from Te Waananga o Raukawa. Winiata has given permission for this photograph to be used in this research study.
} 
Produced from the fruits of Papatuuaanuku, this piece of work depicts the muka fibres woven by hand to make the kaupapa of the cloak. The aho is the whakapapa and whanaungatanga thread; the vertical thread kootahitanga. The warp and weft. The many woven threads symbolise and acknowledge these concepts, allowing the endurance and strength as a floating veil, which enhances its connection with each of us (Rewiri, 2005). The body of the cloak is the whakapapa and life-stories to be disclosed by the participants.

While reading work with the aim of gaining inspiration on how to construct this particular section, academic writers and researchers such as Paul Diamond (2003), Estelle Mulligan, (2003), Cherene Neilson-Hornblow, (2004), Rose McEldowney (2002), Maureen Holdaway, (2002), Rachel Selby (1999) and, the Aboriginal nurses (Goold and Liddle, 2005) stories showed ways in which this chapter could be represented. These various writings bring a distinct quality with the use of different type face to represent what they are conveying. It also reflects the different worldviews held by the various participants as they unfold their stories.

How would I go about constructing and weaving these whakapapa and life-stories ensuring that the voices of the six participants, Kim, Ani, Te Ata, Hineroa, Margaret and Aroha are at the forefront of this study? I will indent, italicize and use font 12, Times New Roman to introduce aspects concerning each individual participant at the beginning of each whakapapa story. The opening comments will be applicable to their thoughts and they will critique what is to be exposed. Maaori words will continue to be italics in this chapter as in previous chapters. At times Maaori words will not have approximated meanings alongside in Paakehaa, as the essence of the conversations will be lost if this is attempted. The other aspect in which to project these whakapapa and life-stories is the order in which I will present them. This will be from the tuakanalteina viewpoint that we as Maaori are familiar with. In customary times this was a behaviour that ensured that whanaungatanga was practiced by both older and younger members of a whaanau. It was also a practice related to teaching and learning where the eldest would manaaki the youngest member of the whaanau. As a kaupapa it brings with it a strength and bond, which creates protection of each another in the whaanau, as too with these six participants. 
It became evident as I read each transcript that 'being Maaori' is central to these participants. As one engages as a reader of this research regarding the participants' whakapapa stories, a number of ideas and thoughts emerge but the kaupapa allows this to be acknowledged in a way that reflects the worldview held by these women. For example the use of whakapapa as a concept has not been illustrated by the participants in the same way as I as the researcher has identified in Chapter 2, page 35 in regards my whakapapa. In our conversations each participant acknowledged knowing their whakapapa but to identify how they were going to reflect this, mihimihi is the technique by which this will be illustrated. Joe Te Rito (2007) contends that there are many ways in which to represent whakapapa within one's work. During the course of writing his thesis he has adapted the customary whakapapa technical terms and introduced new contemporary ways of identifying whakapapa as a concept to suit his work. During the conversations, the participants were able to recall stories that outlined their beginnings, whaanau, hapuu and $i w i$ influences, becoming a nurse and events/reforms that impacted on them and how they related with their worldview, all of which identifies 'being Maaori' as the central focus of their conversations.

While finding time was a concern, getting the six participants to consent and talk about themselves needed prompting and reassurances that this would not be viewed as being whakahihi (all knowing) or for them as individuals to assume credit for the collective effort of many. In Chapter 3 the whakataukii (Diamond 2004) e kore re kuumara e ki ake ki a ia he maangaro, still holds sway today. So, rather than holding them up as exemplar of being Maaori nurses, this research aims to make it possible for others to learn from the experience of these six participants. With this comes those influences of both Maaori and Paakehaa within their lives. At times the advice sought and given was not as productive but in the main it was a fruitful journey for these participants in becoming a nurse. Five of the participants have married outside of their culture and produced children from these unions. The sixth is a child of a mixed marriage. What becomes obvious for those born near their marae, the tikanga and kaupapa associated with this worldview becomes a predominant pathway. For those not exposed to this till later in their lives their stories reveal that they have all benefited from this experience. They all acknowledge their whaanau, hapuu and iwi influences. Events/reforms that have impacted throughout these participants' lives have been considered to gauge the consequences this may have had on their nursing practice and the value it had on the care for Maaori. The work undertaken 
(for example Mulligan, 2003, Neilson-Hornblow, 2004, and, Holdaway, 2002) has contributed to the understanding around such aspects. There are concepts of Maatauranga Maaori that are central to these participants and they will be woven throughout their conversations. At times there will be the obvious concepts which each participant brings to their whakapapa stories, but there will be differences, which I mentioned in Chapter 1. What will follow is the contribution of the whakapapa stories of Kim, Ani, Te Ata, Hineroa, Margaret and Aroha.

\section{Whakapapa story of Kim}

The first whakapapa story is that of Kim's, which I commenced initially at her home in Tuurangi in the most enchanting garden that I have ever been privileged to experience. The capturing of the bellbird sounds and the slight rustling of the leaves belonging to the native trees as the wind blew, 'wove a poignant spell'. It is in this setting that Kim begins her conversation by saying, when I introduce myself to people I say 'Noo whea koe/Where I am from'. This is for many reasons but most importantly it enables the essence of who she is today and how much she understands, or doesn't understand, and there's lots of the 'don't know' in her about why she is and who she is today. The beginning of her mihimihi states

I am Ngaa Puhi and Ngaati Kahungunu iwi.

My hapuu are Ngaati Whakaeeke, Ngaati Ue, Ngaati

Tautahi, Ngaati Rongomaiwahine and Ngaati

Pahauwera. I also have Scottish and Welsh ancestry

\section{In the beginning}

To open with 'where I am from' is who I am needs to start with Kim's whakapapa. She was born on the $5^{\text {th }}$ December 1936, which fell on her maternal grandfather's birthday, and his name was Aldolphus Henrici Stuart. So if we trace her whakapapa lineage we will see exactly how she is situated and disclosure will reveal evidence of Paakehaa ancestry, which is part of 'who Kim is', which she acknowledges in her mihimihi. 
Kim was named Kamiria after her father's mother who was Kamiria Toomuri. Regarding Kamiria Toomuri (the person Kim was named after) she died in the 1918 flu epidemic and her role in this was as a nurse. Part of her families responsibility was to look after the sick people and Kim's father can remember going around with his mother driving what was known as the 'death cart' which was used to pick up the dead people who were then buried in mass graves due to this epidemic that affected them all. Her family name is Pou and after the death of her father's mother, her grandfather remarried and his wife's name was Iwa Te Awa.

Kim's maternal grandfather was Aldolphus Henrici Stuart. His father William Henry Stuart of Ayrshire, Scotland, married Nihipora Henrici of Ngaati Kahungunu iwi affiliation. Her maternal grandmother's name was Florence Grace Evans and she was of Welsh descent. Her mother was Norah Henrici Stuart and she was born in London, England. On Kim's mother's side Stuart Henrici is the Danish side of the family. The Stuart Henrici lineages, link the whaanau through Ngaati Kahungunu to the Solomon whaanau and Ngaai Tahu iwi affiliation. Her mother went to Wellington Girl's College but her father felt at the time that she was getting above her station with her education, so removed her from this setting and put her into a trade whereby she became a tailoress. She was aged fourteen at the time. As children they had the most beautifully made clothes and most of them hand made by their mother, a skilled seamstress. She made clothes mostly for her family and extended family.

Kim's father (Paraiki Kawhe Pou) was educated at Tipene (Maaori Boys College), which at that time used to be situated in Parnell Road Auckland opposite Queen Victoria College (Maaori Girls School). The two schools were opposite each other. The Pou whaanau had a great deal to do with these two schools and contributed to the funding and support of these institutes. Due to his pathway in education Kim's father's next step was to be sent to Parliament and he made a career in this particular vocation. This was due to the fact that this family had a history with people being involved in politics. Yet his passion was for maths and he became a public accountant. His preference was in working in the outdoor environment hence his beginnings with the New Zealand Railways.

In those days there were such things as 'arranged marriages' and her father was no exception. Every time this became a subject of discussion Kim's father would 
conveniently 'run away' from these situations. Some years later (they) returned back up North to meet with this particular woman who had been 'picked' for him and after embracing, discussion centred on the past arrangements for them to marry. The woman was so pleased he had 'run' away because she said he was like a brother to her and she couldn't see a relationship being cemented because of her thoughts and feelings in this direction. The issue around this arranged marriage was the connecting and linking of their respective whenua ownership by the two families in which this marriage would have seen the forging of the two titles.

Kim's father came to Wellington in 1929, where he boarded in Tinakori Road. When he married they lived in Tinakori Road for a brief time. The marriage of Kim's father to her mother was cast in another light by the whaanau, (particular by both sections of this relationship). Both families did not approve because the Pou were very much High Church of England believers and her mother came from a Methodist background. But to add insult to injury they married in a Raatana Church in Wanganui. This caused all sorts of problems but the union of the two people was conducted (even though it was a mission in itself to get to the church to be married, which is another story in itself). They were founding members of Ngaati Pooneke and both were active sports people.

They lived in Upper Hutt while the railway employed her father and this is where Kim's early childhood schooling began. One memory of that time was a friend (Paakehaa) she had. Her father and Kim's father never went to the Second World War, which was an event that was occurring at that time. They were manpowered by the Government of the time. Children whose father's were at war resented this and remarks were made to them, which Kim never forgot. Her father obtained a position at Huntly with the railway and they all moved there where she recommenced her schooling at standard three level. They were singled out being railway children and where they lived was on the west side of the bridge at Huntly. On one side of the railway line were the Maaori children's homes and on the other side the Paakehaa children's homes. Her sister Aneta, and Kim would get on a push bike they had which was a very unusual shape, pedal like crazy to make it past the Maaori children's houses so they would not get pushed off and then had to make it through the gauntlet of the Paakehaa children who were waiting to extract some sort of punishment on them both on the other side. Being railway children brought with it a stigma that singled them out as being different from the other children at school. This label came from 
those who lived in Huntly but it was never part of Kim's or her sister's thinking. It is interesting to note that most of the workers on the railway were Maaori. To be labelled by other Maaori children in this way at the time didn't make sense to Kim because some of these children's parents worked at the railway too.

Kim's father was offered a promotion as station master in Taihape and her mother informed her father that he would be going there on his own, so he didn't accept and they moved back down to Wellington and lived at 29 Cameron Street, Kaiwarra ${ }^{66}$ or what is known today as Kaiwharawhara, where she attended Kaiwarra School. Kim then went to Wellington Girl's College and spent four years there. She loved everything about college life and while there she undertook the professional course, which consisted of French, Maths, English and Science. Because she did not concentrate at this level and was naughty at school, she failed school certificate not once but twice.

When she was in the fifth form her father left the railway and they moved between the Trentham and Heretaunga transit camps. If you wanted to obtain a state house in that period you had to go and live at the transit camp, which was situated, either in Miramar or the Hutt and as a family they lived in the Hutt camp. There they made many friends of many cultures and there social life was continuous. They used the army camp swimming pool, which was near them, and they had access to the army camp picture theatre. One problem that arose at that time, which was the early $1950 \mathrm{~s}$, was that migrants were getting off the boats from England and walking straight into brand new state homes without having to reside in the transit camps like everyone else. Kim loved those years at the Trentham camp and her first boyfriend, was from there and she has fond memories of this as a place of residence.

Whether it was the impact of the war, there was a lot of socialising and drinking, but Kim learnt a side of her father, which had an impact on her life. He would drink to a stage where he would resort to physical violence with her mother. Kim learnt to detest her father when he was in these moods, venting his anger on her mother, and she found it unbearable and expressed this verbally to him. In discussion around this with Kim she felt she

\footnotetext{
${ }^{66} \mathrm{Kim}$ states that the spelling of the word Kaiwarra was the way in which it was illustrated while growing up in her day in Wellington.
} 
suppressed this image to the subconscious part of her mind and vowed that she would not marry a Maaori male because after her own experience they were all capable of violence.

\section{Becoming a nurse}

When we begin Kim's journey into nursing it will become evident that the people who influenced her decisions about nursing were mainly Paakehaa but at what point in her life did 'being Maaori' become predominant. The later statement reflects the professional and personal circumstances Kim found herself in and this will be outlined shortly, in this section. Kim's father was the generation of Maaori who moved from their marae, hapuu and $i w i$ situation and into the cities. This became known as the urban drift, which dislocated Maaori away from their whaanau, hapuu and iwi influence. In Kim's case and in particular her father's, they never returned home to live and only went back for occasional visits. This had an impact on that generation of Maaori even though in Kim's family situation her parents were supporters and participated in the Ngaati Pooneke club that was formed in Wellington. This establishment brought into Maaori people's lives parts that were missing - that had been left behind when shifting away from their marae environment.

Kim's introduction to nursing as a career started at the age of fifteen when she obtained a position as a cleaner at Silverstream Hospital. Cleaning the shower blocks was a ritual part of Kim's life experiences, while employed there. These shower blocks had red floors and they had to be treated with red cardinal polish, which was part of Kim's responsibility to ensure it was removed and the floors left clean. Another part of her job was to clean down the side strips on the wooden side of the hospital beds as well as scrubbing the walls.

The motivation for Kim to apply and obtain a position at Wellington Hospital as a nurse aid occurred because of two reasons. First, Kim received considerable encouragement from her father to achieve and second, the failing of school certificate. She was seventeen years of age at the time and she worked in the children's medical ward. A person who played a major role in Kim becoming a nurse was Sister Mary Coleman and she supported and encouraged Kim to further herself, and that nursing was the pathway for her to take as a profession. Every opportunity for Kim to gain knowledge and skills to become a nurse was part of the contribution by Sister Coleman. It was through her perseverance that Kim gained the opportunity to be accepted as a student nurse at Wellington Hospital six months 
later. Two aspects were needed, for a person to be accepted as a student nurse; first, a person had to be twenty-one at the time of registration and second they needed to have School Certificate, both of which Kim didn't have and it was through Sister Coleman's recommendation that she was able to gain qualifications in nursing. Kim sat Junior State Exams and passed so she then went onto complete a qualification as a registered general nurse on June 1956, just six months short of her twenty-first birthday. To gain registration Kim had to wait till December 1956 when she reached twenty-one to be recognised in the field of nursing. Throughout this period of time Kim became further disengaged from things Maaori.

A long awaited time had come for Kim. She had graduated and then applied and obtained a position in the operating theatre. Here, Sister Kathleen Morgan and Sister McCombie both experts in their field of practice, mentored her. While there, Kim had the opportunity to undertake a post-graduate diploma in operating theatre management and technique, which she successfully completed. During this period Kim met her future husband Allan Furner, who was Australian and was in Aotearoa on a working holiday. Because he needed money to continue his holiday he found work in Wellington and they met through a mutual friend. They married in Aotearoa (1958) but left to live in Australia (Hammondsville) and while there Kim became pregnant with their first child, which put her nursing career on hold. As Kim comments she 'rushed off to the kitchen sink'. This was a period in her life that took her further away from her roots of being Maaori into a world that held other values and beliefs which Kim took on board because of the situation she was now in.

Once the opportunity arose Kim went back into nursing and she found a position in a senior citizen's hospital in Hammondsville. Kim had never seen residential services for older people of this magnitude. There is an interesting history to this, as the whole land and area that the village was on had been won in a horse race between two bishops of the Anglican Church. The deal was if this particular bishop (Bishop Hammond) won then he would develop a village for needy people and that's how that village came into being. The church built the first house. It had one acre of land with it and the idea was that the residents would grow their own food. They paid minimal rent and in turn they helped the next family build their house and so on until a whole village was built. They reserved another piece of land for the hospital and a little single house and then double units and these were 
rented to people who would have hospital support. Kim believes the people back then who developed this idea were very 'visionary'.

Another opportunity arose for Kim when a position became available in Liverpool Hospital, which had private, intermediate and public bed allocations. She noted that the staff consisted of nurses being employed in the private and intermediate areas; those sick people who could afford insurance were housed here. Hence, a high calibre of staff applied and worked there. Those accessing the public system were cared for by minimal staffing numbers and the care being given was like that of any public health nursing system found in other countries. In hindsight Kim noted that she was now entrenched in nursing not from a Maaori worldview but from a Western viewpoint, which continued for quite a long period of time while she resided in Australia.

The way in which the system worked was that the majority of consultants who provided the service to the hospitals were also the general practitioners. This was new to Kim because in Aotearoa family doctors were in the community and consultants and surgeons worked in the hospitals. Hence, in this area these consultants had their own private practice, they would run their consultancy services out of the hospital and they would do private surgery and they would also work in general practice, which meant they had very few problems to contend with.

At this time Kim became pregnant with her second child so her career was again put on hold. When she was able to return to practice she obtained a position in general practice on evening surgery and these hours suited her circumstances. In this practice there were three general practitioners and each were specialists in the field of paediatrics, surgery and obstetrics/gynaecology. Because the hours were part-time, an opportunity came up in the same field of practice for full-time work but with a large contingent of general practitioners - eight doctors, a dentist and a specialist. This practice was situated in the Green Valley.

It was in this period that a great travesty occurred for Kim in that her husband Allan died while playing tennis (1969). He was a representative of the Blackwell cup team at that time. With a young family and the circumstances she found herself in, Kim wanted to stay in Australia and nurse but she eventually relented because of her circumstances and returned to Aotearoa with her children and resided in the Lower Hutt. 
During this period (1971) Kim became actively involved in the New Zealand Nurses Association (NZNA) and she was secretary of the Hutt Valley branch. At this time the association focused on the professional development of nurses and it was in this period that a new move was made by the organisation and they introduced an extended role, which was the union movement of supporting the working conditions and salaries of nurses. Also in this period there was no branch of the organisation in relation to Maaori as there is in today's society. Thelma Burton who was actively involved in this movement ensured that the purpose of this organisation was to introduce a union arm to its policy and procedures. At one period in Kim's life when she needed support from the association due to an issue of work impacting on her practice - and this support was not forthcoming, Kim ceased being involved.

While at Hutt Valley and still in maternity Kim met her second husband Ramsay Newton and from this relationship another child was produced. Kim was approached and seconded to teach in the field of maternity, and was also introduced to Plunket nursing. At this period of her life Kim resat school certificate, which she passed. As there were no nursing vacancies at Hutt Hospital, Kim decided on becoming a Plunket Nurse and did not return to the Hutt Hospital. She became a student in the first Plunket course which was run in Wellington and this was financed by the Hutt Hospital. Kim gained a qualification in this field of nursing. In this era (1974) a report was produced recommending an inquiry into the services provided by Plunket nurses. This was orchestrated by Doctor George Salmond (the then Director General of Health), which reviewed the Plunket system and the services provided by these nurses. The report did not portray nurses in a positive manner and following the review many of these nurses' lost their positions. Kim felt that these nurses were unjustly treated.

Another major event that occurred in this period was the land march (1975) initiated by Whina Cooper who with hundreds of other Maaori marched from the top of the North Island through its centre to Wellington, delivering a petition regarding the unlawful confiscation of Maaori land. This protest gained Kim's attention and her thoughts would return to issues impacting on Maaori when these occasions occurred.

Kim secured a position at Titahi Bay as a Plunket nurse and she cared for over one hundred and sixty babies. At this time Plunket expanded its services and introduced a new position 
in Porirua for a senior Plunket nurse, which Kim obtained, and in this service there were seven Plunket nurses and four Karitane nurses. The Porirua Community Health group was established, enabling other nurses to meet and discuss what was happening in their areas. This was a period in Kim's nursing practice when she was introduced to 'political awareness' for nurses. But what did not occur for Kim personally and professionally was the re-establishment back with being Maaori. This thread was still missing in her life of nursing.

At this period in her life, Kim's husband decided to purchase a garage in the National Park area and so they moved. Plunket heard of her move and approached Kim to be the nurse for the Taumarunui area, because their original Plunket nurse, left suddenly. She accepted and during 1979 - the 'Year of the Child', Plunket established the first mobile nursing service. Kim had a moderate budget, which allowed her to develop and implement a twenty-six week course being offered between the University of Waikato, Hamilton Teachers, Waikato Polytechnic, Educational and Social Services in conjunction with the Department of Education. This resulted in producing nurses who were skilled in the area of child health. Not only did the graduates receive a diploma in child health - it also produced teachers for the programme. There were twelve nurses in this programme. Kim in this period was invited to develop and implement a post-graduate programme at Waikato Polytechnic, but due to personal circumstances to do with her husband's business she returned to run the garage.

While running the garage Kim became an employee for the National Park, and she informally resumed her registered nursing duties (but not paid in this position) and extended the Iwikau first aid base centre. Kim developed and was a member of the first professional ski patrol where they had one ambulance and were interlinked into the hospital at Taumarunui providing medical services to the area. This needed to happen because there were no doctors in the area due to a practice not being sustainable as the area depended upon tourists and was a seasonal business. Kim was in constant contact with the doctors based at the hospital so when it came to implementing care she did all of this before the people were moved to the base hospital. Kim gained huge knowledge and confidence while in this role. 
An opportunity arose which Kim applied for, and obtained at the Waikato Polytechnic as a lecturer in the Child and Family paper for year two students. She completed a certificate in teaching from the Auckland Teachers College and while at Waikato Polytechnic began the journey of being reintroduced and re-locating herself into the Maaori worldview. A person who influenced her was John Tapiata (Department of Education) and Kim was fortunate to attend a hui held at Waahiao marae in Rotorua (1982) where twelve Polytechnics were represented with thirty Maaori tutors. Fifteen of these Maaori tutors were with the Huirangi Waikerepuru Language Department of the Wellington Polytechnic. While at the Waikato Polytechnic there were two other Maaori tutors, Carolyn White who ran Business Studies, Jim Ranginui who oversaw Buildings and Kim in Nursing and Health Sciences. At this period (1984) in the political history of Aotearoa, the then Lange Government held the first hui Taumata and at this time Claudia Orange launched her book on the Treaty of Waitangi. It was also when the Labour Government of the time reaffirmed the Treaty of Waitangi.

There were several important events that occurred at this time, which were to have a profound effect on Maaori and particularly for Kim regarding being Maaori because this became the journey she undertook to gain the knowledge to help develop this part of her that had been lacking. In 1985, Kim attended the hui Waimana at Raatana Paa, Wanganui. This hui attracted students, tutors and others, and what Kim recalls especially is a comment by a student which has stayed with her to this day; how are you (the tutors) going to keep me culturally safe? In 1987, an educational hui held at Rehua marae, Christchurch was organised, which Kim attended as did a great many influential people both Maaori and Paakehaa, involved in many facets of professional development. Another major undertaking was a hui held at Tapu Te Ranga marae, Island Bay, Wellington whereby people such as the late Irihaapeti Ramsden and Mihipeka Edwards attended to continue the movement forward for changes for Maaori.

At the same time Kim applied for a position at Taumarunui Hospital, which she obtained in 1986 as part of senior management. One aspect that Kim wanted to confront was making change for Maaori within this environment. In 1987, she applied for and obtained a position at what is known today as Whitireia Community Polytechnic. Prior to this it was 
known as Parumoana ${ }^{67}$ (dirty waters), which the powers that be at the time thought was a suitable name, which proved wrong. Whitireia is the mountain at Titahi Bay-significant for Ngaati Toa $^{68}$ as used as a location beacon. While there Kim remembered that people would attend student hui they organised and around five hundred people would turn up and be hosted at Takapuwaahia marae. Kim became involved in a number of sub-committees, one being part of the group that constructed the Kawa Whakaruruhau/Cultural safety questions for state finals for registered nurses, before they became multi choice questions. Kim and Pauline Hill were the only cultural assessors who were part of the development of cultural safety questions when it became multi choice.

In 1991- 3, Kim applied and obtained a position within senior management in Community Health with the Manawatu and Wanganui District Area Health Board and its catchment was very extensive. What Kim noted while in this position was that she was not able to effect change for Maaori and this was due to the political policy of the Government of the time, which didn't help Maaori in the health settings. It had a profound effect on her.

The next and final move in Kim's nursing profession is where she is today in Tuuwharetoa health, based at Tuurangi in a senior management position. Besides the health movement, Kim became involved in accessing funds for a registered nurse service to the twenty-one Koohanga reo. Today through various reasons there are now only twelve still established, delivering and teaching Maaori to our children, together with health services being provided to these children and staff. She is also a kaiawhina within Te Waananga o Raukawa.

\section{Events/Reforms}

In the various conversations with Kim over the period of one year, she commented that the movement in health events/reforms have impacted hugely on Maaori. The results have been less then favourable for Maaori at times, and when there is a positive outcome, this is changed by the Government of the time or the new Government in office.

\footnotetext{
${ }^{67} \mathrm{Kim}$ contends that her father made reference to the fact that it was named because of the way in which the water was perceive to look like. The local Maaori would go to these waters and collect seafood for consumption.

${ }^{68} \mathrm{Ngaati}$ Toa is the $i w i$ associated with the North Island and can be located on (Appendix 2) number 29.
} 
Kim's first position within the health system was that of a nurse aide. The history surrounding the name for these nurses began with the 1925 Nurses Act. In 1966 the nurse aide programme was phased out and replaced with a programme leading to community nurse registration (Adamson, 1998).

Kim's next move was to apply to become a general nurse. 1901 was the year in which Aotearoa led the world in commencing registration for nurses. These nurses were hospital based and trained - and these trainees were the biggest contributors to the workforce. Over time and with international influences in the profession of nursing, a review of its training methods was advised. In 1971 Doctor Helen Carpenter was assigned this undertaking and, from her report, recommendation was made that a more theoretical educational model be introduced. This became the document which saw the traditional Hospital based training being phased out and, the introduction of a registered comprehensive nursing programme being brought in (Donley, 1998). 1973 saw the move away from Hospital schools of nursing into Polytechnics. 1979 was the year midwifery followed this development (Mulligan, 2003).

Kim's professional pathway took her into midwifery, and then Plunket where she nursed in various areas of the organisation. Birthing for Maaori before the introduction of missionaries and settlers was conducted by Tohunga. These specialised healers in Maaori communities provided all health care for their people. However, in the eighteenth and nineteenth centuries with the arrival of Paakehaa from other shores there came values and beliefs not associated with a Maaori worldview. The Tohunga Suppression Act 1907 was introduced, outlawing practicing Tohunga, as the Government of that era, believed only in health care from a Western viewpoint. Their outlook was that anything involving the care of Maaori was shrouded in myths and practices that were not beneficial to the health and wellbeing of Maaori. The Tohunga Suppression Act was repealed in 1964 (Durie, 1998) but not without the erosion of sixty years of customary knowledge and skill. Kim notes that there is a movement for whaanau, hapuu and $i w i$ to regain this understanding through academic studies being conducted at Te Waanaga o Raukawa.

On further investigation, the consequences associated with this view for Maaori women were revealed for Kim All care for women having babies were to be under the supervision 
and guidance of doctors and this came about through the Commission of Inquiry 1937, into maternity services. This report outlined that hospitals represented scientific medical care of an advanced nature and these were promoted as environments, which offered security to women and their babies. With this view the introduction in 1938 of the Social Security Act provided free hospital and maternity birthing under medical supervision. The outbreak of epidemic diseases amongst Maaori during this period, and the high loss of life, caused fear to spread among whaanau, hapuu and $i w i$. Because of this they embraced this health care provision and as such these services were introduced into Maaori communities (Durie, 1998).

More changes occurred in midwifery from regionalising services during the 1980 s to the present day situation, where midwives are practicing independently. The amendments to the 1977 Nurses Act in 1990 allowed independent practice by midwives, and also saw midwifery separate away from nursing as a profession. In conversation with Kim, it became apparent that she was associated with highly professional and skilled midwives when independent practice was first promoted. She was fully supportive of this move at the time.

Kim's contact with Plunket evolved through maternity work and as such she was exposed to the concepts involved with this health service. The Plunket Society (1907) was founded by Frederic Truby King. He set out to improve the care for mothers and infants, creating a nursing pathway as he went. Christine Andrews (2002, p. 67) states, "Plunket nursing became part of the backbone of a fledging concept in the New Zealand nursing profession". As a Plunket nurse the care Kim provided to mothers and babies was based on the philosophy and beliefs prescribed by the initiative of Truby King and modified through her own understanding.

With Kim's present day employment the development of Maaori iwi providers came out of the changes made during the 1970 s and early 1980 s by the Government of that period. In this period Maaori became progressively more vocal regarding the link to culture and health. At a hui Whakaoranga 1984 it was recommended that there needed to be an increase in Maaori participation in health (New Zealand Ministry of Health, 1984). In a policy statement made by Koro Wetere (1988) Te Urupare Rangapuu a commitment was made for the Crown to enter into partnerships with $i w i$, funding delivery of services on the 
Crown's behalf. Iwi were then able to become a formalised legal body under the then short-lived Ruunanga Iwi Act 1990. This Act was repealed the same year it was passed. In 1984 a committee was formed known as the Board of Health Standing on Maaori Health to advise on policies. It replaced the Ministerial Advisory Committee on Maaori Health in 1989. Both were short-lived and made limited progress but this led to the current structure of the Maaori Health Directorate located in the Ministry of Health in 1993 (Durie, 1998). The recognition of Te Tiriti o Waitangi by the Crown was narrow within this initiative. It was this project that enabled the progress of the development of Maaori health providers.

Kim notes that over that period of time, each reform led to a shift in the authority responsible for purchasing primary health care services, starting first with the Area Health Boards (1983-1993), the Regional Health Authorities (1993-1998), the Health Funding Authority (1998-2000) and the District Health Boards, which are currently in place. This is the arm that governs the funding for the $i w i$ providers that impact on organisations such as the one where Kim is employed. The current development is the District Health Boards, which now have an association with Public Health Organisations, which have become the primary area for providing health services to the population in Aotearoa, which includes Maaori. This new trend is contributing to Maaori providers moving to this type of service. As Kim has indicated these changes are happening over a very short period of time and are currently impacting on Kim and their iwi service provider. This gives support to Kim's reflection on the way that the Crown reshapes or displaces existing Maaori providers, without consultation at times, despite policy and strategy statements that speak to Te Tiriti partnership between the Crown and Maaori, and Maaori providers (Lavoie, 2003).

Kim has experienced and seen so much in her life time and her journey has seen her entrenched in a worldview not of her making at the beginning of her professional pathway. As one reads this story what becomes obvious are the different points in time that have impacted on the worldview Kim has been embedded in, and which position where she stands today. She commented to me in one of our many conversations that her father said in regards to her name 'your journey in life will be one of many circumstances, that you will take with you' and for Kim, this has been one such journey. What has occurred is that at a certain point in time she has reconnected and relinked with 'being Maaori' in a way that has seen the emergence of a collection of kaupapa expressed in Chapter 5 to be part of 'what' and 'how' she applies her understanding of Maatauranga Maaori. 
The next participant to reveal her whakapapa story is Ani. She was born at a rural settlement called Ruuaatoki. Ani's whaanau, hapuu and iwi resided here and this is where Ani learnt what and how 'being Maaori' meant and the tikanga and kaupapa associated with this worldview. Central to Ani is the factor that she is fluent in te reo Maaori and is embedded in a Maaori worldview. The similarity between Kim and Ani is the era in which they practiced and the reforms in health, which occurred that, impacted on them both.

\section{Whakapapa story of Ani}

The next whakapapa story was shared by Ani and her initial conversation was conducted at her home in Mangaweka. After our third conversation I began to realise that Ani was recounting aspects regarding her mother that reflected how she reacted to situations. It then occurred to me that Ani's behaviour when engaging in conversations for this study needed to be in a mindset and space that would allow answers to be forthcoming. I thought that Ani was not as vocal as I felt that she could be and I became concerned and voiced this to her. She reassured me that this was a trait of hers since childhood and the answers I needed I would find in our conversations.

\section{In the beginning}

In the opening conversation piece, Ani begins with her mihimihi:

Ko Taiarahia te maunga

Ko Ohinemataroa te awa

Ko Te Mahurehure te hapuu

Ko Te Rewarewa te marae

Ko Rangi Moaho raaua ko Kuramihirangi ngaa whare tuupuna

Ko Tumatauenga te whare kai

Ko Te Purewa te tangata

Ko Tuuhoe ${ }^{69}$ te iwi

\footnotetext{
${ }^{69}$ Tuuhoe is the iwi associated with the North Island and can be located on (Appendix 2) number 19.
} 
When introducing this section on Ani, one cannot help but get the impression that she has lived 'being Maaori' because of what she determined should be mentioned and the priority she would like this to be given. When outlining her parents' whakapapa line of their marriage, Ani insisted on including her father's first marriage, because his first wife (Matewai) was the twin of Ani's mother (Nawarihi). They have never been known as stepchildren to each other but a collective of whaanau children connected by whakapapa line through two sisters being the first and second wife of Ani's father. Ani was born into a large extended whaanau and has a twin sister (Hineira). Her mother was the homemaker (leaving school at standard four) and ensured that the home fires were kept burning, whereas her father (Harry Tata Wepiha), being an educated man (Te Aute College in Hawke's Bay), worked in an 'office scheme' which began because of the initiative of Sir Aapirana Ngata.

Ani expressed that her primary school life (Ruuaatoki primary) holds fond memories for her. The whole centre of her schooling was at Ruuaatoki, so it became her world. All the whaanau and extended whaanau attended this primary school. Hence, the time spent was not only learning but the fun and playing were very much part of her early life. Even when they left the school gates to go home, they played and enjoyed one another's company whether down by the river swimming or just playing games. They grew up knowing each other and the value of freedom was forever present. Freedom to go out as a group and each one kept an eye out for the other. It is the tuakana/teina process applied here even though as children they didn't have a specific name for such actions, they knew what they knew. The older children cared for the younger children. The main language spoken by the children was te reo Maaori because their teachers were their old people whose first language was te reo Maaori. Through their schooling English became the children's second language.

Ani indicated that the marae played a major part in her life. As a whaanau they were always doing things at the marae. This is where she learnt to manaaki people in a way that we as Maaori are attuned to and taught. She remembers the people who came from around the marae with fondness and the times spent in the evening when the manihuri would be there and the stories were told. As children their responsibilities were not those of the adults but their learning began in earnest on what the kawa of their marae meant, which was a natural part of their growing up years. The aspect of the way people dressed for the 
formal occasions on the marae showed they didn't have the material objects to flaunt; however, the most important aspect was how they portrayed themselves as hosts and what their speakers presented on the paepae. Ani believes that te reo Maaori when spoken conveys a softness and brings a different slant to what is being said.

In those early times the hapuu worked together as they were situated centrally around the marae. Ani's whaanau lived on a farm, which was near the marae and when any large type of work needed to be done all those connected to the hapuu, participated. One big event was hay making and was reciprocated when other extended whaanau needed assistance with the same task. This also occurred when planting crops such as riwai. What did evolve was the closeness and the kaupapa of whanaungatanga, which went further, then the single whaanau unit; it went to the hapuu and to the valley. Ani states that there was a healthy rivalry amongst the hapuu, which is still there today.

Religion was a major part of Ani's upbringing and the faith they attended was known as Haahi Mihingare. It was very strong in Ruuaatoki at that time because of the mission that was established there and run by two dedicated Paakehaa women. One of these women was a registered nurse and as time progressed would be involved in Ani's journey to Rotorua where she would be a nursing home sister. As children they attend church every Sunday. There were two other religions present Ringatuu and Hareruia (as she knew it) and both were strong within their community at that time of her growing up. Ani still carries her religious upbringing into her later years.

Ani has been a widow for ten years. Her husband was Paakehaa and an outdoorsman and enjoyed this environment and loved hunting. Marrying someone of a different culture was not difficult to comprehend but she could understand if your tikanga is different there would be times of struggle for people. She regards this like osmosis whereby the stronger of the two comes out the winner, which in her particular marriage 'being Maaori' for her children was important. It becomes difficult, Ani believes, with children, because unless you are fully aware of your tikanga and kaupapa from your worldview, how you impart this knowledge is important and can impact on how they view the world. If you cannot do this well then the children do not get full benefit from this knowledge being conveyed. It has this trickle-down effect to each member of the whaanau. Throughout this whole section we have gained insight into what and how 'being Maaori' is central to Ani. Even 
when marrying someone not of her culture she did not lose sight of the knowledge gained from being on her marae and around her old people and still being embedded in her first language te reo Maaori.

\section{Becoming a nurse}

Because of the encouragement of her parents, particularly her mother, who had noticed that women of child bearing age were becoming pregnant at an early age in Ruuaatoki, Ani was sent to Te Waipounamu Maaori Girl's College (boarding school) with five other girls including her twin. They had already had three years secondary schooling, which enabled them to further their education (at this school). With the sway of the church and those people of influence at that time, and the earlier comment regarding the young women becoming pregnant, a decision was made for them to attend this college. All of these girls' first language and in which they conversed was te reo Maaori and they never lost sight of who they were as Maaori because of their language and the way in which they were brought up as 'being Maaori'.

They went as a whaanau group to Te Waipounamu Maaori Girl's College and they retained their whanaungatanga, which had been established since the day they were born in Ruuaatoki. They did not feel out of place because they had each other and were supportive of one another. Ani completed School Certificate and six form qualifications, which enabled her to contemplate teaching or nursing being the only two professions available to women at that time (1950s). She applied for both but ended up in the general nursing programme and commenced training in 1958 at Rotorua Hospital. This is where her journey began to become a nurse.

Ani enjoyed her student nursing days but what she does remember is how regimented it was and the consuming of kai where you had to sit in military style and eat which was something as a young person growing up in Ruuaatoki she hadn't experienced before. But this didn't faze her in the least during this time of her life. To her it was all part and parcel of being educated. The class consisted of half the students (twelve) being Maaori and this enabled them to be who they were without any difficult. Those who spoke te reo Maaori would use it in conversation with others but it is the kaupapa of whanaungatanga, which was never lost by these women, because it is a natural progression for each of them when being away from home. And for those who have been fortunate, like Ani, in being brought 
up by their old people on their marae surrounded by everything reflecting 'being Maaori' then one does not loose sight of this kaupapa.

Ani graduated in 1962 as a registered general nurse and all the Maaori student nurses with her completed at varying times. She stayed at Rotorua Hospital for about six months earning enough money to go overseas and bought a one-way ticket to England. Other nurses had sufficient money saved to buy a return ticket but not Ani, she liked to live on the edge and being young and impetuous (not a word I would normally associate with her) she 'only thought of today and never tomorrow'. Positions for registered nurses were readily available at that time overseas and she worked for a private nursing bureau, which recruited nurses. Ani worked to make enough money to travel abroad and her travels took her to Belgium, Holland, Denmark and Norway where she toured and never worked in nursing. Norway was where she did finally start nursing and she obtained a position in a rehabilitation unit and the experienced she gained was highly beneficial. Even though she could not speak Norwegian there were ways to make oneself understood, which worked for Ani. She stayed overseas and nursed for about two years and while in Denmark met her future sister-in-law. Her husband to be was in Aotearoa travelling around the country (from Bluff to Cape Reinga) and he arrived in Ruuaatoki and met her sister who mentioned Ani was in Denmark. One thing led to another and she met his sister who invited her back to her home and this is where the friendship led to marriage to her friend's brother on her return to Aotearoa.

Ani came back to Ruuaatoki but knew she needed employment so she applied for and obtained a position at Auckland Hospital in theatre working as an ear, nose and throat nurse and while there married her husband, Jens Prip. Because Jens employment was the outdoor kind he obtained a position at Palmerston North at the Massey University, piggery. The physical conditions became unbearable so he applied for work elsewhere. At this time Ani became pregnant with twins and stayed home to care for her children. Jens obtained another position in the outdoor work he enjoyed, at Pahiatua, and then they moved on to Rangiwahia where he was employed as a rabbiter and then they finally settled in Mangaweka where Ani returned to nursing. Over that period of time she became a home mother and cared for her children. 
Ani commenced nursing at Taihape Hospital on part-time night duty. Once her children were of an age where she could resume day employment she obtained a position as a practice nurse. During this period she took a break from nursing and did one year as a kaiako (teacher) within the Koohanga reo movement of that time. She returned to nursing at Taihape Hospital and while there heard of a public health nurse's position being available, which she applied for and obtained. In 1993 a position became available for a Maaori co-ordinator in Tamariki Ora (well child) with the Korimako Health organisation, which she stayed with until 1996 when she returned to Taihape as an independent cervical smear nurse. Her position was extended and she became the Maaori co-ordinator of cervical screening to cover a large catchment belonging to Mid-central health.

To achieve a clear portrait of Ani's life over time, the backdrop of whakapapa was used as a visual image to produce the information needed to write and clarify this part of her life. We refocused and reflected on this as an aid during Ani's third conversation. This proved beneficial as Ani could relate well to this imagery and she also produced her copy of service record in the profession of nursing in Aotearoa to validate what she had done throughout her nursing career. I remember having one myself but lost it at some point in my professional career. In the conversations with Ani she has used te reo Maaori to express what she felt could not be clearly achieved in English and this became a regular feature of our conversations. Ani also believes that 'being Maaori' and her upbringing throughout her life including her marriage to someone not of her culture, has not deterred her in any way from being Maaori and being true to the tikanga and kaupapa practiced by her whaanau, hapuu and iwi. Another aspect around Ani is she is a kaiawhina within the confines of Te Waananga o Raukawa and contributes her knowledge around Maatauranga Maaori, particular around the tikanga and kaupapa associated with this viewpoint.

\section{Events/Reforms}

Ani was of the same opinion as Kim, sharing that when positive outcomes occur for Maaori when the various health events or reforms are implemented, the Government of the time changes the policies that enables the benefits. These changes overshadow these positive results, resulting in confusion for the health services and those health professionals trying to ensure the care to Maaori is maintained. It is less than an ideal situation for all involved to be in. 
On reflection Ani recalls accounts that she has read in relationship to Maaori women who joined the Maaori Health League during the mid-30s, and who were part of the development initiated by Te Arawa ${ }^{70}$ women of the Rotorua district. This was in response to a serious concern regarding sanitary living conditions, infectious diseases and high infant mortality (Dow, 1999). The Department of Maaori Affairs promoted the establishment of a new national, co-ordinated, Maaori welfare organisation. The result in 1951 was the formation of the Maaori Women's Welfare League whose aim was the promotion of all activities that would improve the position of Maaori, particularly women and children in the fields of health education and welfare (Maaori Women's Welfare League, 1993). The first president was Whina Cooper who led the land march (1975) from the Far North to Wellington, in protest at Maaori land confiscation.

More reading by Ani uncovered greater understanding of the era around the 1930s, where the health system had remained virtually unchanged, but in the 1970s pressure was applied that forced change. Ani commented that changes in the health system have been ongoing since the mid-1970s and as such have spiralled out of control. Concern was raised regarding the economic climate, increased costs and demographic changes, and it was felt the public-funded health system could no longer sustain care. This resulted in a series of Government-funded reviews that recommended structural changes. In 1983 the Area Health Board Act was passed and there was limited reference to Maaori and Te Tiriti o Waitangi. Ani felt that because of the paucity of reference in this new act, to the Maaori community, the barriers to accessing primary care for Maaori resulted in substandard outcomes. She also recalls that Maaori women suffered greatly from inaccessibility, transport problems and having no money to pay for health care visits to their General Practitioner. This had a flow-on effect to their whaanau, hapuu and $i w i$.

Ani completed her general nursing at Rotorua hospital. This programme was hospital based with nurse trainees such as Ani making up part of the workforce. However, because of the concerns regarding the type of nursing training being implemented, plus the influences of international views, Doctor Helen Carpenter initiated a review in 1971. This review resulted in a more theoretical educational model being suggested, which was aligned

\footnotetext{
${ }^{70}$ Te Arawa is the $i w i$ associated with the North Island and can be located on (Appendix 2) number 13.
} 
more with international development and eventually this led to nursing training being shifted from the Hospitals into Polytechnics in 1973.

The introduction of the Health and Disability Services Act 1993, Ani believed, should have contributed to improved health care, particularly for Maaori. However, she felt this did not eventuate because of the way in which Te Tiriti o Waitangi had been reflected in this document. The three principles involved; protection, partnership and participation should have provided support for Maaori in obtaining health care, but Ani feels this is not the case. If the Maaori who access health care services are confident in the protection, partnership and participation provided then a wellness outcome will result.

When I posed the question to Ani around te reo Maaori (because of her involvement as a kaiako) she recalls the consequence of the introduction of Koohanga reo 1982 as a movement, which had an impact on the provision of health care. This had a major effect on Maaori people as well as the use of the language. Not only did this ensure the survival of the language of Maaori but it allowed access for Maaori health professionals to care for the children involved in these programmes. This health care service provided an opportunity to address health issues that may have impeded Maaori children's success in education. Having regular health checks ensured that these children maintained good health, which, in turn, helped maintain their educational progress. This had a positive impact on the entire whaanau, hapuu and iwi. Ruuaatoki School (where Ani attended) was the first bi-lingual school in Aotearoa (O'Regan, 2005).

Another event Ani recollects was the introduction of Kawa Whakaruruhau/Cultural Safety into the nursing curriculum (Ramsden, 1992). Ani noticed that those nurses who attended and gained insight into this concept became a lot more confident in caring for the diversity of people presenting in health services. However, she also feels that it lacks the understanding around Maatauranga Maaori and its inherent values, which Te Ata also expressed in her conversation.

The next participant's whakapapa story to be woven is that of Te Ata. There are many similarities that connect Te Ata and Ani. Both whakapapa to Tuuhoe as an iwi and have an association with a community known as Ruuaatoki. Te Ata's first language is te reo Maaori as with Ani, and their upbringing has been centred around their marae and 
grandparents. Whereas Ani started as a registered general nurse, Te Ata was first introduced to nursing through the enrolled nursing programme.

\section{Whakapapa story of Te Ata}

I begin Te Ata's whakapapa story by disclosing how expressive and engaging she becomes when conveying 'who' she is through the karakia and the waiata she sings at the conclusion of her mihimihi; and this is very much part of 'who' Te Ata is. All is dialogued in te reo Maaori and when transmitted in her first language she portrays and expresses an essence which I liken to that of wairuatanga. It is not a religious connotation I refer to, rather what is expressed in the words and actions she uses to convey her messages, which brings forth this particular kaupapa. The true essence of the message is expressed in her manner by the use of te reo Maaori and I also feel that when she is singing her waiata, her tuupuna are standing beside and singing with her. During her whakapapa stories 'who she is' becomes evident in the use of her first language te reo Maaori and this brings a softness and a way of conversing that is not evident when she uses the English language. My perception is that wairuatanga becomes obvious when Te Ata uses te reo Maaori. Some may then argue that wairuatanga is 'who she is' which would be correct but our kaupapa are interwoven and interconnected and can cross over to other facets.

\section{In the beginning}

To understand Te Ata is to know and realise that she was born at Ruuaatoki and is the youngest member of the ten children of her whaanau. She lived and was raised by her great grandmother but this didn't become a barrier for her accessing her whaanau. Te Ata's parents lived close by and it was easy for her when she felt homesick or the need of the company of her whaanau, to put a 'lit' candle in her window at night which would signal to her parents she would be coming home for a visit. Te Ata's primary schooling was conducted at Tawera and then she went onto Ruuaatoki District High School for a short period (three months) after which she lived with her sister and brother-in-law in Whakataane. Here she attended Whakataane District High School until her third year. A vivid memory was in regards to the cooking classes she attended because of her upbringing, 
where the girls learnt to cook and bake at home from an early age. When performing the task of baking scones as part of her cooking assessment class, Te Ata never measured as her instinct reverted back to how she was taught at home, 'eye assessing' and 'use of hands' for the correct measurement. By not using the correct utensils or taking into account the correct criteria for baking (which meant she needed to use the recipe book provided) Te Ata was marked down even though her scones were puffier than any other person's in the class. Her interest in this area was not forthcoming so she engaged in maths and science, which she enjoyed, but did not find the challenge she was 'looking' for while a student. What Te Ata did not lose in this environment was her te reo Maaori because at every possible opportunity Te Ata spoke in her first language.

Whaanau of Te Ata's were living in Hastings, Hawke's Bay and because she spent many holidays there her schooling changed direction. She left Whakataane and concluded her educational experience at Hastings Girl's High School, which certainly challenged this young woman from the small rural community of Ruuaatoki. This experience made her 'grow up' very quickly, as nothing in Ruuaatoki had prepared her for this. When attending the Maaori culture group at Hastings Girl's High School, the whole atmosphere and kaupapa was certainly different to that taught at Ruuaatoki by the old people. Despite all the good intent on people's behalf, to capture what one's tuupuna have taught, this gets lost in the whole transition period and it is this, which people are attempting to recover. Another part of this 'growing up' period is that they worked on her brother-in-law's orchard and helped with the smoko's and the stacking of boxes for the workers packing apples. In the afternoon they went off to the movies and this exposed her to the types of movies available. Around this era Doris Day and John Wayne films, were looked forward to, and the treat after the movies was to purchase some fish and chips for tea while waiting for their whaanau members to pick them up.

The orchards and shearing sheds where she resided became the focus of her life. Her sisters worked in shearing sheds so her exposure to this type of employment became a natural progression. Through working in the shearing sheds her three sisters all eventually married three brothers from the same whaanau. Te Ata married (William Tukioo Munroe) and from this union three children were produced (Charlene, William and Ngaire). 


\section{Becoming a nurse}

While Te Ata worked in the shearing sheds and the orchards, she felt that she didn't want to stay here for the rest of her life. With three children already in hand she needed a new direction in life. She had heard through various people that there was an enrolled nursing programme being offered at Hastings Memorial Hospital and because it was only for twelve months, Te Ata enrolled and was accepted. This began her journey in nursing. This was the first enrolled nursing class (in 1978) to be held in Hastings and was a hospitalbased training. Because of this, there were only a small number of trainees involved. Five students were Maaori and of the five, four passed and gained qualifications as enrolled nurses. Some of these students were fluent in te reo Maaori and at every available opportunity Te Ata would speak in her first language, even though the educational journey on caring for people, particularly Maaori, was in English. While employed as an enrolled nurse Te Ata gained insight and knowledge into various areas of nursing practice. She first started in the orthopaedic ward and spent a period of three months there, moving to the intensive care unit and then on to coronary care. Maternity became a small part of her development for a short stint and then onto the gerontology, medicine and finally the surgical ward. While nursing in these areas Te Ata would communicate where possible with both Maaori staff and patients in te reo Maaori when the occasion presented itself. Te Ata noted how easily information regarding the person being nursed was exchanged in the dialogue with Maaori staff using te reo Maaori as their means of communicating, causing the relationship between the two parties to become different. This exchange allowed whanaungatanga to be a kaupapa that everyone engaged with and it then encouraged staff conversant with their first language to dialogue more readily with each other.

While at Hastings Hospital, Te Ata learnt that they were phasing out the enrolled programme of nursing and their positions would be disestablished. This motivated her to embark on another pathway and in 1988 she enrolled in the comprehensive nursing programme offered at the Hawke's Bay Polytechnic, now known as the Eastern Institute of Technology. There were eleven Maaori students enrolled in this comprehensive nursing class. During this period of achieving academic qualifications and recognition, some of the Maaori students, because of personal and whaanau commitment reasons, dropped out. Isolation away from whaanau proved difficult for those students and it was particularly noticeable with those who came from Tairawhiti (Gisborne). This became part of the 
underlying factors, which impacted on their, not completing the course. While there Te Ata had to repeat the first year because of personal issues impacting on her, and it was through this period that she started to 'listen' to people's advice regarding how to achieve completion of the programme. Early on through this period of study she felt she knew everything there was to know about nursing, but this certainly was a wake up call for her when she had to repeat the first year of the programme again. Of the eleven Maaori students, seven completed and gained qualifications as Maaori registered comprehensive nurses.

Upon graduating Te Ata applied for positions at Whakataane and Kimberley hospital, in Levin, Horewhenua. Whakataane did not accept her application but she was asked to go to Kimberley for an interview for a registered nurse's position and this was another issue altogether. She was short listed and invited to attend an interview, whereby she took her two kuia as support. One of the questions asked of her was ... "where do you see yourself in two years time?" ... and her answer was ... "sitting in your positions". That was not what they wanted to hear. One of her kuia trod on her foot when this question was posed but Te Ata took no notice and continued to give her honest answers. Of course she didn't get the position and her kuia told her in te reo Maaori, "you didn't get the job because you were being too smart for your own good" and "couldn't you feel me on your foot". In reply she explained to her kuia that she thought she was just "stretching her leg and accidentally knocked her foot, so she just shifted it to make more room for her". That experience did not faze Te Ata in anyway and she put it down to 'learning'.

On Te Ata's return to Hastings she received a phone call from the Hastings Psychiatric Unit asking if she was interested in a registered nurse position that was available. Her immediate reply was 'yes' and so began her introduction to the world of psychiatric nursing. At that time there were five Maaori registered nurses working in the acute unit with her as well as a small number of Maaori enrolled nurses and health professionals. These small number of Maaori health professionals spoke te reo Maaori at every available opportunity, using it when having conversations and dealing with the care of those who were Maaori. It was a natural way of communication for them because it is who they are. After a period of time she applied for a position in the community, (about 1995). At that time only one Maaori person worked in this area and that was in a position as a social worker. Te Ata's application was accepted and she had the opportunity while in the 
community to work in Wairoa as a duly authorised officer and part of her responsibility was to implement the Mental Health Act. Her view on achieving this was from a Maatauranga Maaori continuum and to her it meant there were other means of caring for our people without putting them into the acute environment under this Act. It was looking at ways in which the whaanau and extended whaanau could maintain and care for their own within their homes with her support. This meant that our people still maintained their mana. The professional decisions she made did not fit into the Western thinking of her colleagues, as they believed our people needed to be admitted to the acute in-patient unit at Hastings.

This role allowed Te Ata the opportunity to hold discussions conducted in te reo Maaori with the whaanau (about their whaanau member who was being cared for). Our Maaori people did this when they didn't want those who were not Maaori to know what they were conveying. Operating in this manner allowed the mauri and mana to lie with the people. At the same time a new programme was introduced which allowed for what Te Ata called the shared tiers. This encouraged and supported the decision-making process of the doctors input and the Maaori registered nurses opinions to be part of the care for the person who was unwell. It then allowed the introduction of te reo Maaori as a kaupapa of communication with those of our people who wanted to conduct their conversations and care in this manner. One aspect that was difficult to manage was the understanding around the role of social workers in this whole process because they did not have the authority to prescribe medication; only the registered nurse in consultation with the doctor had this authority. The ability to maintain and manage this was 'testing' on a person in this role but it was done with the utmost professionalism, ensuring that all involved had their mana in tact.

Te Ata moved and worked in Te Puawai o te Whaanau in 1997 which was in the community. This allowed her to practice from a Maaori viewpoint. While working there she was able to develop the knowledge and skill to write a proposal to shape what she determined as services appropriate to handle Maaori needs out in the community. This service was to be provided to Maaori by Maaori for Maaori. This allowed those health professionals who are confident in te reo Maaori to be able to speak with each other and also to those who access their services. A means of communication for those who are fluent in the language becomes a way by which to engage with the person and there 
whaanau, allowing dialogue and information gained in a manner that recognises the person's language as being paramount. Te Ata had difficulties gaining movement with her proposal and this was due to the fact that she did not whakapapa directly to Ngaati Kahungunu ${ }^{71}$, but that was overcome by whanaungatanga with whaanau members and this allowed the proposal to proceed for consideration. There were three deliveries being mooted; first the establishment of a day programme; second, the creation of a day care programme; and third the approach of having a consultation liaison person between the community and the hospital. The only one accepted and allocated funding was the day care programme to be established for Maaori and this came under the umbrella of Te Taiwhenua Heretaunga, which was a recognised health provider service for Maaori in Hawke's Bay.

Te Ata stayed and developed the programme in conjunction with others but she felt that there was a need to move on in nursing practice and gain new insight and knowledge into what she wanted to achieve. This led her to apply and obtain a position with Te Rau Matatini where she became project co-ordinator, but this role has now changed to specialist trainer in workforce development with the medium of te reo Maaori as a focus to reach our people. Another major contribution she makes to the continued existence of Maaori is the delivery of knowledge, which she has gained over the years as a Maaori nurse to those Maaori students fortunate enough to enrol in the Oranga Hinengaro (mental health) programme offered at Te Waananga o Raukawa. When teaching students particularly years two and three, all Te Ata teaching is done in te reo Maaori, which these students are conversant and comfortable with. In my observation of this in the classroom situation, I note a different dimension and slant being portrayed both by the person teaching and the students. It is the kaupapa of wairuatanga that becomes evident when students are able to explain exactly what they want to convey in a language they are comfortable in and they are able to express aspects that can never be captured by the use of the English language.

At another stage in her life Te Ata was actively involved in the New Zealand Nurses Organisation (NZNO) in the branch that involves Te Ruunanga, which is specifically for Maaori nurses. She held the treasurer's position but on reflection felt she has achieved nothing worthy of change for Maaori nurses. Te Ata believes that while it is important to

\footnotetext{
${ }^{71}$ Ngaati Kahungunu is the iwi associated with the North Island and can be located on (Appendix 2) number 20.
} 
have a union arm that oversees Maaori nursing staff and their status, any changes in policy and practice should be associated with a wellness focus and health outcomes for Maaori as a people, which then has a flow-on-effect to those Maaori health professionals caring for our people. This stance is also reflected in Margaret's whakapapa story around this particular professional nurses' organisation.

\section{Events/reforms}

At times in Te Ata's life there were events/reforms that impacted on her but when answering this question she stated 'when in practice I did not think about whether the legislation or policies that ensure that we could practice safely, was in place'. My role was to care for people. To go about my everyday practice thinking about these aspects would not have occurred to me as I believed there were others in more senior nursing positions to ensure this happened.

Gathering her thoughts, Te Ata recounts her journey into nursing as a Maaori enrolled nurse. History indicates that the Nurses Act, 1925 recognised nurse aides, but the introduction of the second level of nursing did not occur until 1939. In the 1945 Nurses Act section 15(a) they were finally acknowledged. The original training involved an eighteen month programme, which was hospital based. In 1966 the nurse aide programme was replaced with a programme leading to community nurse registration. To advance their experience a basic six months course was endorsed in selected areas of practice. Endorsements held little acknowledgment, except in the area of practice and were not acknowledged in educational fields, and generally produced no monetary rewards. This programme was one, which I, as the researcher, enrolled in at Hastings Hospital, Hawke's Bay in 1968 and graduated from in 1970. Due to the high attrition rates among community nurse students, a decision was made in 1971, to review the programme (Clark, 1989). A report was produced by the New Zealand Nursing Manpower in 1977, to examine this process. This group consisted of nurses from the New Zealand Nurses Association, who were, in all truthfulness, an improvised committee. The report they produced recommended reducing training and a name change for these second level nurses. Most of the students enrolled in these programmes were Maaori. The 1977 Nurses Act changed the name for these nurses to enrolled nurse and shortened the programme to twelve months (Adamson, 1998) and this is the programme Te Ata completed at the Hastings Memorial Hospital. 
An area Te Ata found challenging was that of Kawa Whakaruruhau/Cultural Safety. Ramsden (2002) contends that cultural safety has been developed with Maaori cultural reality. Te Ata believes this statement is not fulfilled as described by the late Ramsden, by those steering this curriculum today within nursing education and practice. The many changes since the inception of Kawa Whakaruruhau/Cultural Safety, is one that has seen the worldview (rather than that of Maaori) to be the foundation of this knowledge base. To achieve understanding Te Ata is convinced that the Kawa Whakaruruhau component needs to be taught in Whare Waananga from the worldview of Maaori, and the cultural safety perspective from those Paakehaa educational institutes designed for this. At present some tertiary institutes are categorising this curriculum knowledge under Maaori studies instead of its original area of nursing.

Te Ata recalls the inclusion in Government policy decisions of the introduction of Te Titiri o Waitangi signed in 1840, which became known as a 'living' document between Maaori and Paakehaa. As far as Te Ata is concerned this is a controversial document. In contemporary terms Te Tiriti provides three principles, protection, partnership and participation in relation to health. Te Puni Kokiri (1993) contends that Maaori and the Crown under Te Tiriti ensure that health care is provided in these areas. Te Ata confers that translatation of this from a Maaori viewpoint is that any person and their whaanau have an equal relationship with health service providers by all sharing a partnership, protection and participatory role in a person's care, thus ensuring a positive outcome for that person (Nielson-Hornblow, 2005). This as a concept was easy to gauge but hard to implement because of the structure of the Governance level of management (Durie, 1994) which has a trickle down effect into health areas. Through various levels of management this meant that the understanding around Te Tiriti, was lost on some people in the health area who really had no idea what this meant regarding the provision of care. Another view on the value of Te Tiriti for Maaori is that expressed by Mason Durie (1989) states Te Tiriti $o$ Waitangi is neither a blueprint for good health nor a remedy for all ills. Nevertheless, good health is undoubtedly an objective of Te Tiriti.

Te Ata believes that with the various board changes, including the establishment of the Ministry of Maaori Development, Maaori Health Directorate and the District Health Board, progress has been made for Maaori, particular in primary health care. However, Te Ata noted that there are silent changes afoot, which she believes involve the funding for 
Maaori iwi providers to now be allocated to District Health Boards, where $i w i$ providers must apply. Te Ata sees major consequences with this, as Maaori are competing for the same financial contracts, resulting in small monetary amounts being given, which will lead to substandard outcomes. Everything entailed in making an iwi provider successful is slowly being eroded away. Unless $i w i$ organisations have very good management structure, a large catchment of Maaori population and access to doctors, as well as an abundant supply of Maaori registered nurses, they will survive. If not, then it will be a constant uphill struggle.

Another major change Te Ata remembers is that of the Mental Health Act 1992 which saw the introduction of dignity, self-determination and respect for people, but more importantly cultural awareness. Health professionals felt this gave support to Maaori, but Te Ata believes it is a very small piece of a jigsaw puzzle and there are some important pieces missing in this area. Te Ata contends that Maaori would be best served by ensuring that the kaupapa associated with their worldview (for example whakapapa, te reo Maaori, wairuatanga, manaakitanga and whanaungatanga are but a few) are introduced as a way in which to care for our people. Once understood and established Te Ata insists you will see a positive result in the health and wellbeing of our people. The development of polices, procedures and management of Maaori services should be guided by these kaupapa but at present we have an attempt to balance both Maaori and Paakehaa viewpoints, which has not been beneficial to Maaori. We as Maaori health professionals need to be confident in the way we practice and care for our people so that their health and wellbeing is paramount and this needs to be done from a Maaori worldview.

Another event that Te Ata recalls was the deinstitutionalisation of mental health services which began in the 1980s. Closure of these units brought with it increasing problems and demands, particular in the area of accommodation. Te Ata experienced the negative results of this when caring for Maaori people in the community - which resulted in financial hardship, lack of suitable accommodation and little support for residential care. Te Ata had to deal with these social impediments before attempting to care for Maaori from a hinengaro (mind) wairuatanga and whanaungatanga point of view. This became the motivation for her to write a proposal, to establish residential care for Maaori. 
Te Ata has woven within her whakapapa story, the way in which she embeds herself in 'being Maaori'. She never strays from this pathway and is confident in being recognised as such. With a worldview that 'being Maaori', is important, Te Ata's upbringing reflects this and central to everything she does is the kaupapa of te reo Maaori interlinked into wairuatanga.

My next participant is Hineroa and like Te Ata and Ani has whakapapa ties to Tuuhoe as an $i w i$ and her first language is te reo Maaori. Hineroa has a close connection to Ruuaatoki and was raised by her grandparents. Her worldview is that of 'being Maaori' and the kaupapa associated with this view as such is reflected and central in everything she does.

\title{
Whakapapa story of Hineroa
}

\begin{abstract}
Hineroa is a very engaging person and during the conversations we laughed at the memories she unfolds throughout her period of growing up. There are several threads that we need to untangle in regards to Hineroa and her beginning in life but most predominant is that she identifies as being Tuuhoe and this is 'who she is'. A question I posed is that 'would she be happy with what is to be disclosed regarding her personal and professional journey'. Hineroa's reply was that she was because 'Bro they may understand me better and then consider why I am the way I am as being Maaori because of what impacted on my life' ...
\end{abstract}

\section{In the beginning}

The home in which Hineroa was born was once her grandmother's (Hine-i-Whakaataea Trainor) chicken coup and this became her permanent residence with her parents and other siblings. Hineroa's grandparents lived and resided by their paa at Puukeko. Hence, she grew up in Poroporo, which is about fourteen kilometres from Whakataane. There is history behind Whakataane and the rivers that run into this estuary. Hineroa's mother (Whirimako Nohotima) is from Apua, which is called Ohinemataroa and this is where the township of Taneatua is situated and where one of the rivers, known as Waimana, flows through the town before meeting the Whakataane river, where the name changes. Another interesting factor is that the marae is called Puukeko and the hapuu is Ngaati Puukeko. 
Her grandfather's (Tei Nohotima) hapuu was that of Ngaati Kahu but he stayed with his wife's hapuu Ngaati Hamua because of a disagreement between the two brothers. This rift went on for twenty years, until one day her grandfather's brother (tuakana) came and apologised for his behaviour, which then led Hineroa's grandfather returning to his hapuu. What her grandfather was renowned for was his 'green fingers' and any vegetables or crops he maintained flourished and grew, and they supplied any function or gathering held at the marae. He was also very good at supplying animals needed for meat, so the hapuu of her grandmother's Ngaati Hamua benefited from this gift of her grandfather. This as a kaupapa would be identified as whanaungatanga being expressed to all who visited this hapuu. When the rift was healed this gift her grandfather had was returned back to his hapuu and they flourished and became known as providers of the food and meat for the people. It is common knowledge that Hineroa's whaanau are very 'straight forward' people, intolerant of people who are not honest. The traits they have, she believes, have not been passed on to the other half of her whaanau.

Besides this attribute Hineroa's grandfather was a disciple of the Haahi Ringatuu religion. He was a tohunga in his own right because of his religious upbringing and his congregation stretched from Puukeko into Waimaa and onto Ruuaatoki. At this period in his life he had built a wharekai right beside their tuupuna Puukeko, which his whaanau objected to - so he shifted it onto his land right beside the paa. He called this wharekai a 'boarding room' which he named Te Puku o te Wheke (the stomach of the octopus). According to Hineroa because her grandfather's people are from the moana (sea) the significance of te wheke to them is very pronounced. Her intrigue with this sea creature stems from this disclosure but more importantly for her - as a creature it travels from one area to another without having a secure place to live. But she feels that its real value lies in what it eats and what it then contains inside its stomach. Just like the crayfish the paru is rich and so too with te wheke. They eat the best of food in the ocean, which in turn is returned to her whaanau when they catch and eat this, as the nutrients it contains are fed back to them as well as their hapuu and $i w i$.

Hineroa's name is another special aspect of who she is. She received this name because at one point in time an aunty of hers had married but found it difficult to conceive so when she and her husband found out Hineroa's mother was pregnant they asked for the child to become their child. As a practice, this was not uncommon at this period in time where 
Maaori women who were barren were able to ask whaanau members to provide children for them to care for as their own. These circumstances regarding Hineroa and her aunty, is how she became known as the long awaited child and so her name means 'long awaited girl'. When she was born her mother couldn't give her up so her aunty did not get the child she longed for. During this period her mother like all the mothers, tended the gardens, which sustained them as a hapuu and Hineroa along with other children of this age where wet nursed by two aunties who had given birth themselves. All of what has been described is what this whaanau, hapuu and iwi practice and is firmly embedded in Hineroa and the way in which she views the world.

Hineroa has a distinct memory of the passing of her grandfather and this was because of the large number of people who attended his tangi. Even though he was Haahi Ringatuu all domination of religion were represented at this solemn occasion. She remembers other things such as the floor in their wharekai being made of dirt and so they had their kai outside on a long strip put down the centre (which contained the kai to eat). There were no luxuries such as lollies only fruit and in particular, bananas, which weren't easily obtained. The pudding was bread and butter so their table was not adorned with today's food of trifles or pavolas. Their kai was cooked in kerosene tins and they had what was a feature of marae cooking in that period - the big black pots known as boilers to cook and boil their water in. Again the expression of whanaungatanga was paramount in formal situations such as this occasion.

This was Hineroa's life until the age of five when her grandfather died, and her grandmother, after a period of time went and lived with another koroua (old man) at Maatau. As an area Maatau represented how Maaori lived before European contact. There homes were circular in nature and in the centre was their wharenui. At some stage in their history they were convinced that this was an inappropriate way of housing people, and shifted to the other side of the road. Their homes were presented in military style, which Hineroa believes eroded away the whanaungatanga that this hapuu maintained. This then resulted in the hapuu becoming unwell and she believes they have never recovered from this change.

Hineroa's father (Matu Hakiaha Wikeepa) whom she describes as a hard worker and a hard man in nature, was employed at the Pulp and Paper mill in Whakataane and at the same 
time he was running the farm. He would not let them mix with her mother's whaanau because he saw his side of Tuuhoe as being 'sacred'. To overcome this obstacle her mother's father would load his Bedford truck up with vegetables and meat and haul it over to them even though they had plenty of food, it was his way of bridging this gap created by her father and to show his love to his daughter and mokopuna. There is another side to him that Hineroa discloses later in this section. It is with mirth that she described the mode of transport that her father used to get him around. He used a rabbit scooter, which her parents and siblings were transported on. What Hineroa has disclosed is her whakapapa linkage to Ngaati $A w a^{72}$ and Tuuhoe, which identifies her with both $i w i$, but most of her upbringing has been from a Tuuhoe perspective, which makes her 'who' she is and contributes to 'what' she does.

In regards to her schooling Hineroa attended Ruuaatoki primary school and then went onto Whakataane High School. All the time she attended both schools she could not read or write and her first language was te reo Maaori because this was the language she was attuned to. Her only attribute is that she loved sports and excelled at these. To get her through the inability to read and write she memorised anything she tackled and so this was the pathway she took until a certain period in her life, which is another story to be told. When she obtained employment she would watch her cousins when they withdrew money to gauge how to do this, but she also got them to write her forms out and she again observed their behaviour and memorised the numbers they wrote.

When Hineroa reached the age of sixteen her mother insisted she work and so a position was found in the kitchen of the local hospital where she washed the pots and pans. This was where Hineroa mother was employed in the domestic area. She was kept well away from anything breakable because she had the habit of dropping and breaking crockery. As mentioned earlier her father was a hard man by nature and he became even worse when he drank. One day, which was a regular occurrence with her father, she came home as he was beating her mother. Hineroa had had enough by this time and she physically hauled her father aside and 'flung' him across the room and told him to 'stop beating on her mother'. What eventuated upset Hineroa because instead of her mother supporting her, she retaliated by hitting her with a broom and this became the 'straw that broke the camel's back'.

\footnotetext{
${ }^{72} \mathrm{Ngaati}$ Awa is the iwi associated with the North Island and can be located on (Appendix 2) number 14.
} 
Hineroa handed in her notice at work, packed her bags and set off for Wellington where her cousins lived.

\section{Becoming a nurse}

Arriving in Wellington, Hineroa remembered from the image created by the advertisement for 'Wilkinson Blades' the name of the street where her whaanau members lived which of course was called Wilkinson. Where her cousins' house was situated in Oriental Bay, one could see the expanse of the marina and the ships that sailed this harbour. Hineroa stayed up all night watching this activity because she hadn't in her whole life time seen this amount of traffic on the roads of Ruuaatoki nor the many lights that these ships displayed. The environment in which she lived allowed the kaupapa she was use to in Ruuaatoki to still be part of her practice inclusive of being able to converse in te reo Maaori.

All of her whaanau had employment of some kind and Hineroa knew she needed to find work. She didn't want to go back to washing dishes so she thought about being an orderly but there were no female orderlies at that time, so the next best position was that of a nurse aide, which she applied for at Silverstream Hospital in Upper Hutt. Most of Hineroa's extended whaanau worked in the domestic area at this hospital and this made it appealing for her when applying for a position. One aspect that Hineroa reflects on is a comment made by her father; 'Hineroa your pathway in life is cleaning toilets and such like, this is your calling' and being the authority figure in their household she felt he must be correct in this assumption. So when engaging in employment she headed towards this type of work.

Hineroa had been employed at Silverstream Hospital for about eighteen months when she felt she needed a change. She applied for positions as a nurse aid in Wellington at two areas, the Home of Compassion and Calvary Hospital. Hineroa took the position at Calvary Hospital because she felt the skills and knowledge she had gained in her previous position, suited her in this environment. Calvary was starting to take in hospice patients and this was where Hineroa first experienced a Maaori woman with terminal illness. What she learnt from this experience set her on the pathway of deciding to become a nurse. Even though she was not a registered nurse Hineroa knew enough about pain and suffering to gauge that this woman needed some sort of pain relief. She informed the nurse in charge who dully informed Hineroa that she had everything under control for this patient. After a time Hineroa checked on this woman to see how she was progressing and was 
informed by the woman's husband 'that she has had nothing' for the pain. This worried Hineroa so she sought out the Charge nurse and one thing led to another, resulting in the woman being given pain relief. Hineroa reflects back on this experience and for the whole duration of that particular shift she was on a high that someone took notice of her concerns and did something for this woman. What happened that day made her more 'aware' that she needed to do something with her life. Hence, the decision to go nursing. She also knew she had crossed the line when she, rather than the nurse caring for this Maaori woman, had sought out the Charge nurse to reconsider administration of pain relief.

Another aspect brought to Hineroa's life was the desire to 'better' herself, both professionally and personally, in her ability to read and write. With her new employment in caring for the elderly who were terminally ill, and the new found relationships developed especially with the nuns and Doctor Kiddle, the residing doctor in charge at Calvary Hospital. Hineroa grew in confidence and felt that the time was right for her to take another journey by becoming a nurse. She entered the enrolled nurse training, which she completed at Lower Hutt Valley Hospital and then decided to continue with her comprehensive training. Before undertaking her nursing training, Hineroa enrolled in the adult learning programme, run at Wellington Boy's High School and the then principal was Turoa Royal. She took herself off the entertainment scene for a year, concentrated on obtaining her certificate in adult learning, which she completed at the end of the year, leading to her being able to commence her enrolled nursing training. Both the nuns and Doctor Kiddle supported her desire to become a nurse. Throughout this time Hineroa didn't lose sight of 'being Maaori' and the tikanga and kaupapa associated with this position.

Hineroa enjoyed her time as a student nurse but she found something significantly missing in her life. First, where whanaungatanga was concerned Hineroa had found ties with those Maaori cleaners and orderlies who worked at the hospital for her Maaori side, but second and most importantly the manaakitanga needed to complete her academic studies, was not forthcoming. She had no support from Maaori registered nurses. One day she was having lunch in the nurses dining hall and noticed a registered nurse who was Maaori and because she knew she was struggling to find that academic support, approached this nurse. After informally introducing herself, Hineroa proceeded to explain her dilemma. After she had finished, this Maaori nurse acknowledged her situation and promised to find other Maaori 
nurses to support her journey. What eventuated was that two others, besides this Maaori nurse participated in Hineroa's academic pathway. One comment this nurse made in regards to Hineroa's situation is 'we have forgotten what it is like to be Maaori, once entrenched in this Western way of thinking' and forget 'where we have come from and who we are', which is 'no different' from you, Hineroa.

Throughout the three years of her training (there were only two Maaori student nurses enrolled in the programme) Hineroa gained new knowledge and developed new friendships, which she took with her on her journey. She experienced some highs and lows, but a particular event that occurred when nursing a young Maaori male, whose injuries were sustained from a motor vehicle accident. In the first two weeks of his admission he had lots of whaanau and extended whaanau visiting him but after this period there was a noticeable decline in those visiting. What Hineroa noted is that the young man was becoming 'mokemoke' in himself or low in mood. She became concerned and voiced her observations to the nurse in charge of this patient, but with no joy, so she decided to contact the doctor in charge of this area whom she knew well because of her past employment with the elderly. One thing led to another and this young man was reassessed. The doctor in question prescribed antidepressants but from the worldview in which Hineroa was exposed to she felt it was due more to the lack of visits from whaanau causing him being mokemoke. She took action by discussing with her uncle to see if he knew such and such whaanau, which he did. They went and visited this whaanau to see why they were not visiting their relation. At the time, this whaanau were all busy with their sporting activities forgetting about this whaanau member in hospital. What Hineroa suggested is they revisit him, but in small numbers, making sure that each day was covered by someone, because she believed this was the reason for his mood decline. When they did visit, there was a remarkable difference in this young boy, no anti depressant medication was needed and he made a full recovery. The way in which Hineroa observed and concluded this as the reason for his 'unwellness' and by addressing this in a way that reflected a Maaori worldview, led to the full return to good health by this young man. Hineroa was always challenging and crossing the line.

Hineroa achieved her aim and graduated but two events impacted on her at this time. First, Hineroa's parents passed away which affected the whaanau where they all disengaged themselves from each other. Second, Hineroa married a Paakehaa but she felt it 
was more a void to be filled then a marriage of love. The union produced two children. Hineroa stayed nursing in the Hutt Valley Hospital for a short period but returned back to Calvary Hospital where she originally started.

As time progressed Hineroa decided to return to Ruuaatoki because she felt that her children needed to engage in developing their reo Maaori. The first Koohanga reo was established in Ruuaatoki. She also applied and gained employment in the District Health area of nursing and this was another journey in her life. It meant that she was involved with her hapuu and $i w i$ that at time tested her beliefs and values but it proved fruitful. In this period she crossed the line continually to support and help make change for her people.

Another opportunity presented itself for Hineroa and she applied and gained a position as a lecturer at Waiariki Polytechnic within the nursing area. She loved the teaching and the exposure to students. The experience was very rewarding for Hineroa and her outlook on life was another step forward to effectively make change for those Maaori students who accessed this institute. Hineroa's daughter had reached an age where she wanted to develop her educational qualifications, so they moved to Masterton. At the same time Hineroa applied for a position with the Mental Health Commission, were she is presently employed.

One other important aspect in Hineroa's life was her involvement with the National Council for Maaori nurses. Her association with this professional organisation lent itself to her values and beliefs that reflected a Maaori worldview. All involved in this organisation are Maaori health professionals who believe in the principles that reflect this worldview and as such challenge the status quo. To be associated with such a stance can cause conflict but it is a movement that Hineroa found solace in. It allowed her to cross the line in a way that would encourage and ensure change. Hineroa believes change is effective when policy and practices align itself with better care and health outcomes for Maaori as a people. This then, will have a flow-on-effect to those health professionals caring for our people.

\section{Events/Reforms}

When considering the question, Hineroa felt that whatever the rhetoric of the events/reforms, the consequences were less then beneficial. The changes resulted in a lot 
of confusion and at times disharmony amongst those providing care, particularly to Maaori. Hineroa felt this was due to the Government of the time and their inability to position and apply Te Tiriti o Waitangi within legislation and policies. Before addressing this, Hineroa wanted to discuss the National Council of Maaori nurses and her involvement with this professional body and why it contributes to this section.

Hineroa contends that the advent of the National Council of Maaori nurses was an important and positive focus in Maaori registered nurses' lives. The inaugural hui of this professional body was in October, 1983. It is the only mandated body, which has the sanction of iwi to represent Maaori on health issues, and this was gained by visiting $i w i$ around Aotearoa. Hineroa maintains that the kaupapa this professional body aspires to is 'being Maaori' particularly that of rangatiratanga and the way it can bind people together to ensure a positive outcome for issues that may impact on them. Its core business is workforce development for Maaori health professionals and as such maintains the kaupapa associated with a Maaori worldview. As a body they were at the forefront of ensuring culture and its relationship to partnership in nursing education and its curriculum, were first established (Holdaway, 2002).

An event that played a central part in the life of Hineroa was that of Te Koohanga reo 1982. Hineroa felt that her children needed to be conversant in te reo Maaori, at one point in her life, so she moved back to Ruuaatoki to ensure this. As outlined earlier in Ani's whakapapa story Ruuaatoki School was the first bilingual school introduced in Aotearoa. Not only did Te Koohanga reo as a movement maintain the survival of the language for Maaori, it allowed opportunities for Maaori health providers to care for the children and staff engaged in these activities. Hineroa recalls the changes in March 1984 to healthcare for Maaori. One change was to establish community health programmes and marae clinics which was advocated at the hui Whakaoranga held at Hoani Waititi marae, Auckland. Recommendation was made that funding be available to establish such organisations. What Maaori were saying was that we, as Maaori, decide how care should be provided to our people. It was during this time that the Women's Health League was formed at Rotorua in 1986 and the establishment of the Tipu Ora (well child) service in 1991. As a result of the success of these initiatives and at the request of the Maaori community leaders, Ruuaatoki opened, a community health clinic bordering the local 
school (Holdaway, 2002). This service catered for the Maaori population and complemented existing social services.

Hineroa understands that as a modern document Te Tiriti o Waitangi promotes protection, partnership and participation. Hineroa believes in all the good intent by Paakehaa to encourage this in health policies and legislation, but as a document, it is never given the mana, mauri and rangatiratanga it needs to ensure that the health and wellbeing of Maaori is paramount. Because interpretation is mainly from a Western viewpoint by those who manage Government positions, there is a flow-on effect, and it loses the wairuatanga, kootahitanga, manaakitanga and whanaungatanga, which it was intended to reflect by those who originally signed. Hineroa contends that what has occurred is an attempt to interpret from a worldview that has no place for Maaori in the health policies and legislation.

The next participant is Margaret and like Hineroa, Te Ata and Ani has whakapapa connections to Tuuhoe. Margaret is fluent in te reo Maaori and maintains the kaupapa associated with a Maaori worldview. This is the whakapapa story belonging to Margaret.

\section{Whakapapa story of Margaret}

Coming from a very small rural Maaori community known as Ruakituri where everyone supported each other, Margaret thought it strange to see people buying firewood because in the area she lived in, it was cut and delivered by whaanau members. As children they would go and get the fruit off the trees and eat it, but here in the urban area you had to go and pay for it. It was a big shock for a person brought up in a rural marae setting where everyone demonstrated manaakitanga and whanaungatanga to all those whaanau members who lived near and around the marae. In Margaret's mind she could picture them as children clambering up the fruit trees even though they didn't belong to them and eating to their hearts content without fear of reprimand. Margaret also reminded me that not only was the kaupapa of whanaungatanga reflected in 'being Maaori' for her but also a collection of other kaupapa-but, importantly, she could also accept being reflected in this manner. 


\section{In the beginning}

Margaret is ninth in line in a large whaanau of twelve children. They lived in Ruakituri where her father lived and she attended the local Ruakituri primary school. Her father (Norman Jackson) attended primary school at Ruakituri but Margaret is unsure if he attended High School. He was not bom at Ruakituri but is whaangai (adopted) and he never left the place because this is where his whaanau residues. So the centre of his universe was Ruakituri. He was a physical hard workingman and provided well for his whaanau and he encouraged the practice of whanaungatanga. He was a native speaker of te reo Maaori just as her mother (Minnie Biddle) was and they lived the rest of their lives in Ruakituri.

Margaret's mother went to Ruuaatoki primary school and it was actually known as a Native school back in that time. She attended this school because her grandfather was the chairperson. The school was some distance away from where she actually lived but because of the position held by her grandfather her mother attended this school. She boarded at this school, run by nuns, at a very young age and only went home in the holidays. The place is still standing today. Her mother attended Whakataane High School where she ended up in Ruuaatoki and meeting and marrying their father. Margaret's mother was a native speaker of te reo Maaori and had an exceptional understanding of their whakapapa and what it meant to them as a whaanau. The old people encouraged her to learn about their history of their people and they encouraged the practice of whanaungatanga whenever people visited or when it was part of their marae kawa.

Margaret is married to Chris Ware, who is Paakehaa. They have two children (Samantha, and Arama) and they also whaangai a niece's child (Haze) and Margaret and her whaanau love him. Knowing about his family or having a close relationship with his mother, Margaret explains that whanaungatanga is not there. On the occasion of the birth of their daughter, Margaret's mother attended the birth and supported her after the birth but they did not see her husband's mother until sometime later. The kaupapa of whanaungatanga was not and still has not been built, yet it has been encouraged, but Margaret believes that they do not know how to express this because it is not part of who they are. However, this kaupapa is demonstrated by Margaret's whaanau towards her husband who adapted and embraced this as part of his life and enjoys the gathering of her whaanau. He fits very well 
into this manner of meeting with whaanau members. The kaupapa of whanaungatanga is practiced widely in Margaret's immediate whaanau, and is embraced by her husband.

Because of their rural situation Margaret attended Napier Girl's High School but boarded at Hukarere Maaori Girl's College. Religion played a big part in her life while there because it was an Anglican Maaori girls boarding school run by the church so they attended church and sometimes they went three times on a Sunday and had chapel morning and night, seven days a week. Being at Girl's High School came as a huge culture shock because it consisted mostly of Paakehaa and where she came from all the people were Maaori or were her immediate whaanau. The kaupapa practiced back in Ruakituri certainly wasn't part of Margaret's schooling scene so she had to adapt and fit the Western viewpoint that was being taught, and, which at times, tested her. She was able to converse in te reo Maaori and be who she was as a Maari in the confines of the boarding school because all the boarders were Maaori from different hapuu and $i w i$ affiliation. In this environment Margaret was able to practice and exhibit the kaupapa of whanaungatanga very comfortablely with those other Maaori students.

\section{Becoming a nurse}

For as long as Margaret could remember she wanted to be a nurse but was unable to give a clear explanation of why she wanted to do this as a career. Her father wanted all his children to become educated and do something different in their lives. She believes this was because he worked hard physically and wanted better for his children. She cannot remember if he ever said 'you need to become a nurse' and during her growing times she never played 'nurses' or 'doctors'.

Margaret was in the last year of high school when her dean called her into her office one day and said 'what are you going to do when you finish school' and she replied 'I do not know'. The dean then said 'what about going into nursing' and Margaret said 'that sounds good'. I will do that. The next suggestion from the dean is that she would be good as an 'enrolled nurse' and to apply for a programme. Margaret knew no difference and agreed to this. She wrote a letter to the Hastings and Waipukurau Hospital as directed. She finished school at the end of the year, and received a letter back from Waipukurau indicating she had been accepted and could start in the 1982 April or October intake. Margaret wasn't quite ready for April so she indicated that she would like to start in October. She 
graduated as a Maaori enrolled nurse in 1983. There were three other Maaori student nurses who also graduated and they developed the kaupapa of whanaungatanga amongst themselves. Margaret still keeps in contact with one of the nurses who is from Ngaati Porou $^{73}$. What she was thankful for was the experience gained in her previous position as a Maaori enrolled nurse and the various areas she worked in because later this was to prove valuable when she enrolled in a registered comprehensive nursing programme.

As time progressed Margaret thought about the advice she had been given and became annoyed that she had listened to and trusted someone who thought that she was only capable of being an enrolled nurse. With the expression of whanaungatanga a person who would be seen as a mentor (as in the case of the dean of this school) would never in the Maaori way of thinking give advice that was not going to achieve the highest accolade in what-ever journey they undertook. However, this was a reminder that a worldview different to those seeking their advice, may bring problems, which may have ramifications for the rest of their lives.

When becoming registered, Margaret worked in Waipukurau as a Maaori enrolled nurse until 1986 where she had a break from nursing and went to work at the Takapau freezing works as a labourer. In this period of time she became pregnant with her first child Samantha. When the baby was six weeks old, Margaret went back and worked as an enrolled nurse, with a nursing agency. The work was varied but most of it was in gerontology. It was about 1989 when Margaret heard that enrolled nursing was to be phased out and a friend who had also trained as an enrolled nurse Mary Anne Hutton, encouraged Margaret to do the comprehensive nursing programme at the Hawke's Bay Polytechnic as it was known as then. She herself was at this institution enrolled in the programme. The expression of whanaungatanga by Mary Anne was not lost on Margaret and she remembers this well.

With these thoughts in mind Margaret applied at the Polytechnic and was accepted for the comprehensive nursing programme in 1990 and graduated in 1993. There were five Maaori students in her class intake, which enabled the building of whanaungatanga, which was part of who they were and who she was. She thoroughly enjoyed her time as a student

\footnotetext{
${ }^{73}$ Ngaati Porou is the $i w i$ associated with the North Island and can be located on (Appendix 2) number 17.
} 
nurse and the enrolled nursing experience provided her with good practical skills when it came to doing clinical on the wards. Margaret can remember having to write a care plan and having no idea how to do this because it was the charge nurse's role and responsibility during her period as an enrolled nurse. What she enjoyed about the Polytechnic programme compared to Hospital training is that you didn't have to do the shift work.

Upon graduating a short term opportunity arose as a school nurse at Karamu High School in Hastings, which Margaret took to gain experience. It was not a position she enjoyed because you were under the supervision of a teacher and it really was a first aid position. Margaret applied for and obtained a registered nurse position in a rest home and when the manager resigned she applied for the position and was engaged in this area of managing a twelve bed home. She had worked in this rest home as a student and this allowed her the opportunity to gain employment. All through this period of training and working Margaret never lost focus of who she was as a Maari and a nurse. Even though her training consisted mostly of Western models this did not deter her from writing or practicing from a Maaori worldview. Margaret believes because of the nursing curriculum, which had to recognise Kawa Whakaruruhau/Cultural Safety she was able to practice as a Maaori nurse It was an important time in her nursing career when this philosophy/set of principles was introduced as it allowed her to include concepts she was familiar with when Maaori patients presented in health settings she was nursing in. It gave her the confidence and security to know that the care being provided was aligned with the philosophy of a Maaori worldview.

In 1994 Margaret's second baby was born. She finished working full-time and went to work at the Hawke's Bay hospital in the casual pool. At this time, an interesting development was underway. Staff wanted to set up a crèche for their children and Margaret became involved because of her circumstances with her baby as she had to leave Arama with whaanau members even though she was still breast-feeding, which was proving difficult to manage, so the crèche was a very good idea. It is the year 2006 and they still do not have a crèche at the hospital for the staff. While in the casual pool Margaret worked in many areas such as medical, surgical, paediatrics and cardiology but she didn't work in mental health and had no desire to do so. In 1998 they regionalised the hospitals and Margaret worked in the Napier Hospital while the new hospital was under construction and once completed returned to Hastings Hospital to nurse. In 1999 a 
position came up within the District Health Board in the new Maaori Health service. Margaret applied and gained the position and she is currently the only clinician within this service. All staff are Maaori and it allowed for the kaupapa in which they believe, to be practiced, particularly the kaupapa of whanaungatanga which is a predominate feature in this department. One of the services to be provided in this small setting is the allocation and caring for whaanau members and any member of the public who have difficulty with travel and accommodation if no family live near the hospital. Rooms are provided where the unit is housed and as such these Maaori staff provides whanaungatanga to those who need to access such services.

In 1997 Margaret decided to go back and do more studies and did a degree in nursing, which consisted of three papers at the Eastern Institute of Technology (which it was renamed). At the same time she had enrolled at Te Waananga o Raukawa in the Hauora papers there. This is when the dilemma for her began. Margaret completed the degree in nursing at Eastern Institute of Technology (2000) but found no value in the knowledge gained from these papers. However, what she was exposed to at the waananga proved beneficial to her. I believe this was because they reflected the worldview Margaret was comfortable in, which was being Maaori and these papers were written from this viewpoint and delivered by Maaori.

During this time Margaret was an active member of the union and remained so until recently. At the time she was interested in professional development for Maaori nurses beside the other arm of the union movement, which concerns employment conditions for nursing staff. Hindsight is a great thing and Margaret realises that while supportive of the staff's conditions and interested in professional development, this would never occur while the union did not believe or understand Te Tiriti o Waitangi and in particular article 2 on partnership. The kaupapa connected with Te Tiriti is not there and the people associated with this movement with all its good intent do not understand nor want to understand what this kaupapa means. Today, she considers that while it is important to have a union arm that oversees Maaori nursing staff and their conditions, any changes in practice and policy should be aligned with better care and health outcomes for Maaori as a people. This will, then have a flow-on-effect to those Maaori health professionals caring for our people. Te Ata has also reflected this view in her whakapapa story while involved in this movement for Maaori nurses. 
At present Margaret is doing studies at Te Waananga o Aotearoa in an undergraduate programme. In conversation around further studies for Margaret, I made comment that I noted she continued to do undergraduate work and wasn't it time she considered postgraduate studies. Margaret acknowledged this and said she was being lazy and definitely would consider this for 2007. Why I made mention of studies was because Margaret needs to ensure that knowledge and new knowledge is vital for the survival of our people as Maaori and particularly in health. Hopefully, 2007 is the year for Margaret to enrol in a Masters programme.

\section{Events/Reforms}

When posed with this question Margaret commented that she felt the other participants would have covered this area adequately and endorsed what they expressed. What she wanted to do was reflect and comment on two aspects, which Margaret felt impacted on her.

Margaret, while engaged in her education to become a registered comprehensive nurse, was introduced to Kawa Whakaruruhau/Cultural Safety (Ramsden, 1992). As a paper it promoted and encouraged nurses to understand the value of people's culture within their care. It was a point in time that encouraged Margaret to reflect and continue to practice and care for Maaori in the way she was raised and as such had no difficulty in comprehending its value. It was a leading reform for Maaori nurses and opened avenues for them. However, Margaret found an area of discontent when engaging with other nurses, who had not had the opportunity to be exposed to such understandings. Nurses who had not furthered their educational development became very resistant to this aspect compared to those who had been exposed. Margaret felt this was a difficult time in the transition period of nurses understanding around Kawa Whakaruruhau/Cultural Safety.

Margaret's exposure while attaining a degree in nursing led her to read and think about aspects around health reforms and the changes they brought. She commented that her understanding of these changes are very broad and at times made her really think and challenged what she could or could not remember. The many health changes Margaret has experienced since she has been in her position at the Maaori health unit have been numerous and have escalated, (she believes) out of control. This was a comment that Kim, Ani and Hineroa all made when discussing this issue. When new Governments come into 
being, they change everything, so that where you no sooner implement one type of legislation or policy, than another one arises. People generally in these positions of health, whether health professionals or managers, Margaret believes, are not coping. For example the Labour Government of 1974 endorsed a paper (New Zealand Government, 1975) that stated that instead of becoming a marketable product it becomes a social service. Margaret commented that what eventually occurred was that it became a market driven health care service.

Margaret is part of a District Health Board that has an arm, which provides advice to Maaori, and she recollects reading various aspects regarding District Health Boards. These boards came about as an idea in the 1970s in the 'Green and White Paper' recommended by the Labour Government. This was part of a plan to nationalise health care as the Social Security Act of 1938 had initially proposed. Labour lost the election to National in 1975. This Government opted to gradually apply these reforms in trial area health boards. Following the success of this, in the 1990s these District Health Boards were renamed Regional Health Authorities. They were then merged in 1997 to form the Health Funding Authority. The election of the Labour-Alliance Government in 1999 saw the return to the District Health Boards in the New Zealand Public Health and Disabilities Act 2000 (Ministry of Health, 2005). On reflection Margaret feels there is little if minimal reference to Te Tiriti o Waitangi in these documents. As a document it does not have the value placed on it from those who are of a Maaori worldview.

Margaret is employed in an area that provides services such as whanaungatanga and manaakitanga to all Maaori. Its other core business is to be a voice as mentioned earlier for Maaori on the District Health Board and provide health services to the wider Maaori community. Extensions to contracts and the encouragement of Maaori determining their health needs, led to this initiative. The objectives for these boards are set by the Ministry of Health and they have a degree of independence in choosing how to achieve this. Since being part of this research Margaret is more motivated to gain knowledge and insight around consequences of health changes and reforms because they are starting to impact more on the Maaori services that she has become part of. To make change successful Margaret believes one has to have a good grounding in the subject matter under discussion. 
The final participant is Aroha who, through the kaupapa of whanaungatanga, has known Margaret where both attended the comprehensive nursing programme, at the Eastern Institute of Technology. Where their educational pathways parted was when Aroha continued her studies at Manawatu Polytechnic but Margaret stayed at the Eastern Institute of Technology. Aroha has travelled extensively overseas to countries such as Australia, Hong Kong, China, Canada, Scandinavia and the Philippines. While in these countries Aroha never nursed but while in China, she worked in an orphanage. Aroha brings to her whakapapa story the challenges associated with being a young Maaori woman of this contemporary period but still being embedded in a Maaori worldview that was nurtured by her grandparents (Charlie and Wiki Jacobs).

\section{Whakapapa story of Aroha}

It took some time for Aroha to decide what to have in this space but she came to the conclusion that she would like to have a photo (Figure 8) of each of her grandmothers. Aroha believes this reflects the stance she has regarding her tuurangawaewae as both grandmother's contributed to this development.
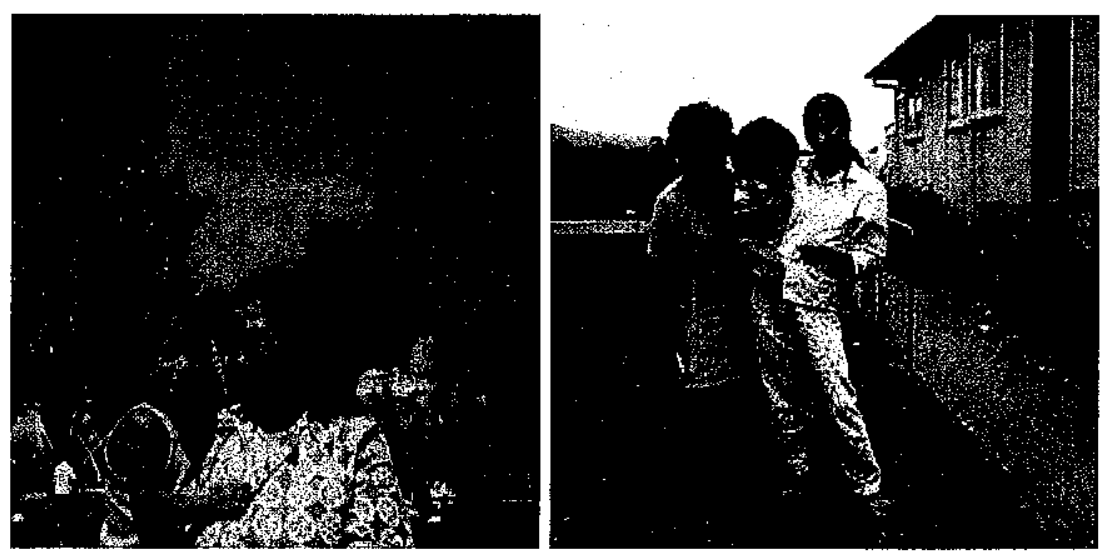

Figure 8: Aroha's tuurangawaewae

\section{In the beginning}

When taking this journey with Aroha we will gauge how she has come to this conclusion. On this journey we will visit many sites, which could be considered in Aroha's thinking around 'who she is', reflecting her tuurangawaewae because her movements had her 
travelling not only through Aotearoa but also overseas. Aroha is forever mindful of her customary upbringing but she believes in a new way of viewing this kaupapa as part of 'who I am' is 'how I am'.

Aroha grew up in Havelock North, Hawke's Bay where initially she lived with both her parents but she doesn't remember much of those times. At the age of eighteen months she went and lived with her grandparents. They were wonderful days filled with laughter and happiness. Her grandparents lived in Palmerston Road in a moderate sized house, which was always full of people. Her grandfather name was Charlie Jacobs and he worked at the Tomoana freezing works and in his spare time he went fishing where he would set his nets out at Haumoana, catch a plentiful supply and dispatch these to whaanau within Havelock North. He described people as being 'poor' and 'hungry' but not in a demeaning way as he knew people struggled to survive. He had a large vegetable garden and he would share this with other people. People today come up to Aroha and remind her about the generosity of her grandfather. Her grandfather was from Kaawhia in the Waikato. He's is the Ngaati Toa and Ngaati Haua ${ }^{74}$ line that stayed in Kaawhia, not the Ngaati Toa that went with Te Rauparaha to Porirua Kapiti. His mother was from Ngaati Haua and they came from the kingmaker's whaanau, Tamihana Tarapipipa. He was whaangai in his younger years and he then grew up with Ngaati Haua whaanau, the Jacobs, the Hakopa. He was very much tuturu Maaori, which was quite typical of Tainui Waikato people of his era. They retained their language so he was a native speaker of te reo Maaori. He was what Aroha described as contrary, as he was not quite typical of a person of that age or era. Yet she would not really describe him as a 'grumpy old man' but he was set in his ways but he was also very comfortable with new ideas. He instilled in Aroha the importance of learning the ways of their people and learning te reo Maaori - and he was also open to other worldviews. He worked with different ethnic groups (for example Dalmatian, Chinese and German people) and he made it his business to learn their language and about them as a people. He was a hard working man and he loved the racehorses as did her grandmother. He was a great believer in the stars and astrology and he did birth charts on all his children and extended whaanau. He taught himself all these skills. Aroha hasn't had much association with this side of her grandfather's whaanau.

\footnotetext{
${ }^{74} \mathrm{Ngaati}$ Haua is the iwi associated with the North Island and can be located on (Appendix 2) number 7.
} 
Aroha's grandmother was known as Wikitoria Jacobs and was from Ngaati Huia ki Poroutawhao where her tuurangawaewae is situated and where her whaanau are the Hapeta. Aroha's grandmother was like a butterfly that flitted here and there. Life was fun with her because you went everywhere and she was well known by people. They were a very close-knit whaanau who raised crops together for everybody, had karakia together, and were great waiata singing people. Her grandmother was a renowned singer in waiata and knowledgeable in this area. Her parents lived in Poroutawhao and her father was Hakopa Hapeta and his father was Utiku Hapeta. He was a disciplinarian regarding singing waiata and it had to be done properly. People would come to her grandmother and ask her to teach them how to sing waiata. They knew of her reputation because of her whakapapa connections. She was also a religious person and she followed Christian teachings. Aroha's grandparents were the life line of what it was to live within a Maaori worldview because they fostered and nurtured this in the environment, which impacted on them 'growing up' and they were the one's that encouraged whanaungatanga amongst the whaanau and extended whaanau. Every Christmas at their house while they were alive the ritual of a haangi was prepared and all her aunties would prepare the food while all the uncles were outside preparing the haangi.

In Palmerston Road where Aroha's grandparents lived were a lot of Maaori whaanau. She would wander from house to house and she knew who made the best kai for breakfast, the Nukunuku whaanau. Aroha would also go to the Davis house to play with her friend Duane and go to the Greville's house (Paakehaa family) but they were warm welcoming and friendly people. So those days were of peace and being safe and doing whatever she wanted to do. It became a mini replica of a rural marae setting but in an urban environment with a mixture of cultures being part of this environment.

Another side to Aroha is her Paakehaa father (Rex Webby) who is from Hastings. He is a committed and loving man. She could always rely on him and he was an outdoorsman so she was exposed to the sea, river and the bush, which her father enjoyed, and she came to enjoy. His mother's name is Lucy Webby and she played a prominent part in Aroha's life. She was a very kind and humble woman and had a quite a reticent personality. She wasn't an 'out there' person and led a quiet life, but the centre of her life was her family. Aroha spent a lot of weekends with her and she became very close to her father's mother, and spending lots of holidays with her father's sister. In this environment Aroha enjoyed the 
love given so freely by her father's family and they in there own way had shown Aroha what it was that their tuurangawaewae represented for them. It may not have been the way in which her Maaori side would have portrayed this but it was still evident and part of "who she is'.

Her mother (Charlotte) had at this time formed a new relationship with a man by the name of Jim Magee and he was Paakehaa of Scots descent. He brought children to the relationship as did her mother but they were never distinguished as step children they were all brothers and sisters, as if of a biological nature. Aroha's mother always wanted to do the 'right thing' so Aroha's early childhood upbringing included attending Havelock North Kindergarten. She learnt lots of social skills in this environment from a Paakehaa worldview. She became bored in this situation and started to get into trouble because if someone annoyed her she would 'bop' him or her so her mother would have to come and get her and take her home. Having a large family, life was never boring and they engaged in lots of activities together. Across the road from where they lived was a large domain where they played for hours on end and her parents encouraged them to be outside a lot. They were also not very far away from Aroha's grandparents so visiting was easy. Aroha's mother encouraged reading so she took Aroha to the library constantly and would read to them every night. She knew that they did not have any Maaori books to read and once when they received such literature it was through her mother's Paakehaa friends.

Aroha went to Havelock North Primary School, which colloquially would be known as a 'white flight' school. Academically she received the best education there was. It was a well-resourced school because it had 'white middle class families' who wouldn't put up with anything less than that for their children. The school attracted the best teachers.

The next journey of Aroha's schooling was the introduction to Havelock North Intermediate and that's where she met Maaori children from Haumoana, Waimarama and Whakatu. When she started at this school it was a big culture shock because it was the first time she had experienced a group of Maaori children around her at any one given time, but she loved it. She hung out at the basketball courts and played in the breaks. This was a new sport for her. Because at Aroha's last school the main games were netball and cricket, her main sporting interests were netball, and she was 'kind of' in the middle aspects of being Maaori. The Maaori children had names for people such as herself and they were 
called 'plastic' Maaori because of her educational upbringing (Havelock North Primary). The others were called 'real' Maaori because they were brought up as such and were rough and ready types of people who lived in the rural areas of Hawke's Bay.

Aroha attended Havelock North High School and with that came friends who were all Maaori so that transition was easy to make. One observation she made is that they didn't have many Maaori teachers. There was one who was brilliant at te reo Maaori but because of Aroha's lack of maturity and understanding, didn't give her the time of day but Aroha commented she was an outstanding educationalist in the language. This teacher left and the next year they were left to their own devices and so the growth of her language, te reo Maaori, became stifled and stunted. What stayed the same was where she was located in Havelock North and so at that period she understood where her tuurangawaewae was but the location never matched that of her grandparents and the memories involved with them.

\section{Becoming a nurse}

Aroha did not have what you would call 'exemplars' as nurses but caring people surrounded her all the time. She had a younger brother who had epilepsy and her exposure to this and those nurses with their white uniforms and white hats made her think of them as angels. This sort of stuck with her as she was growing up and being part of this scene which belonged to her brother's life, became part of her life too.

Aroha can remember seeing this programme on Mother Teresa and as a seven year old she was fascinated by this woman and never forgot what she'd seen on television about Mother Teresa's life-story. Aroha felt that this had planted a 'seed' of wanting to be like someone and Mother Teresa was one person she wanted to be like. At Havelock North High School, they had a career adviser who suggested professions she might like to think about, and nursing came up in the conversation. This, laid the foundation of thinking about this as a pathway for future development. Aroha enrolled in the comprehensive nursing programme at the Eastern Institute of Technology in Taradale Hawke's Bay and there began her journey of becoming a registered comprehensive nurse. This was a very enjoyable time in her life.

When it came to doing the practical or clinical component of her training Aroha struggled immensely. Because she had no experience in this she would systemically go through the 
textbook exercise (in her mind) of performing a shower on a person, which took her ages to complete. Aroha felt those nurses competent in this area must have found her tiresome when she thinks back to this experience. The first person she performed this task on was a lovely lady in a nursing home and nothing prepared Aroha for seeing someone naked and having to shower this person. Nothing prepares a person for this she believes. As her first patient the woman was very kind and appreciative of what a person did for her, as she was in the early stages of multiple sclerosis and anything anyone did she was grateful for. So Aroha's task of caring for her was made all the more easy because of her patient's wonderful disposition. Her husband would come and visit her every afternoon and he was a gentle good-humoured person. This experience lent itself to Aroha as being mindful of what it was to be a nurse, let alone respond as being a Maaori nurse.

In Aroha's second year she went down to the Manawatu and enrolled in the Manawatu Polytechnic. This was closer to her extended whaanau who lived in Otaki and around Ngaati Huia marae. In this class of students were Maaori who were closer to Aroha's age group and they were a very active group of students particularly around things Maaori. They had high expectation for Maaori students and pushed for what they wanted, as a result Aroha attended a lot of Maaori nurses hui. Her first experience in nursing was in the mental health area and at Lake Alice Hospital she gained clinical experience and knowledge. One's experience in the classroom was not the reality of clinical settings. In the hospitals the way of caring was different to that taught in the classrooms. In the hospital it was the old ways and she was shown a number of ways of caring, which became confusing. Aroha did not particularly feel challenged in the various areas but she actually thought that this was the sign of what nursing was going through at that time. She found the diploma in nursing easy to complete as far as the written application was concerned. Putting care into practice was a different scenario again. She struggled and the struggle was not only to practice well as a nurse but to be mindful of whose worldview you needed to reflect in these situations.

In talking with friends' that were studying at a University, Aroha noted they had so many other courses going on around them that they could adapt and take these as well as doing what they had enrolled in. But in the Polytechnic Aroha found it mundane and the variety was not there. She so wanted to learn te reo Maaori but that wasn't part of her nursing curriculum. It was all set out for her with no direction to include anything Maaori around 
the language. She actually came to resent that part of her professional career. Aroha felt sure there were Maaori nurses pushing for this to be included but she believed they weren't being listened to. In today's training especially studying in the University, the ability to be able to include your language is more open to discussion. One can also engage in conversation, which challenges the status quo and Aroha would enjoy these types of debate sessions. When learning about Kawa Whakaruruhau/Cultural Safety the value of this became apparent and this is where Aroha learnt to express her views on what it meant to be Maaori. Her thoughts would always return to her grandparents and their home in Palmerston Road and the many happy memories associated with this as a home. Reflecting on these memories Aroha knew other students were determining to be Maaori and, as well, what was being taught was not what she knew about and had experienced with her grandparents and all those who congregated at their home. One would think when reflecting on this period in her life that Aroha may have felt inclined to want to go back and live in this area of her hapuu of Ngaati Huia, but she did not see this as being who she is in the sense that since the day she was born her beginnings started in Palmerston Road with her grandparents. Hence, she yearned to recognise this as her tuurangawaewae and identify as 'being Maaori' from this stance.

Another aspect of nursing that Aroha felt unfilled in, was in the theory she learnt, which was about North American knowledge. As a new practitioner and because things Aroha had learnt were foreign to her, she struggled with the acceptance of this as being the way to care for Maaori as a people. The kaupapa in which her grandparents embedded her were not the values of this Western worldview reflected in these theories. The nursing process was very important to her because she was conscious that this had become her guiding principles of caring for people. She noted nurses around her were very good at meeting the people's needs but she found that they didn't consider the wider picture of nursing and that was about acquiring new knowledge and techniques. For Aroha to accept someone's comments and views as being gospel without challenging them and giving care mechanically, meant that nursing had lost its meaning for her.

Once she had graduated in 1993, Aroha headed back to Hawke's Bay and her first position as a Maaori registered nurse was in the Rodney Francis ward at Napier Hospital. It was a medical and dermatology ward and she loved the work and the experience it provided, and the nurses who practiced there were excellent in their field. Because it was a provincial 
Hospital one was able to do more caring and learn more skills as opposed to the larger Hospitals such as Wellington. People came in with all sorts of skin problems; infections and she gained more experience because she had to care for these people. There was also the opportunity to work in other wards and Aroha would volunteer to do this especially in the Intensive Care Unit. She would watch these specialised nurses at their tasks knowing she wouldn't be left on her own and the experience gained in this area was huge because of the professional commitment of these particular nurses.

Aroha saw rivalry among nurses regarding the underlying aspect of training - Hospital trained compared to Polytechnic trained nurses, and this was a pervasive occurrence because each expressed they were better trained than the other. There was even evidence that registered nurses thought they were better than enrolled nurses and vice versa. Aroha never bought into this because all she wanted to do was learn and to become an excellent nurse. She would question aspects that concerned her because as a student she was not prepared for some situations that arose on the road to becoming a registered nurse. As a student nurse she felt supported by a tutor and an experienced senior registered nurse, when caring for people but she lacked confidence in situations where she was registered and yet exposed to unfamiliar situations without this support. Aroha believes that as a registered nurse charged with caring for a person, one forges ahead and cares for people to the best of their professional ability, ensuring the best care is provided. Another difference that Aroha noticed was that the mature nursing students, she believed, had life-skills she lacked and they coped better than she did, while she was a student nurse.

Coping with theory based on North American theoretical models and applying this to practice in Aotearoa was very difficult for Aroha to handle. She had difficulty in reading care plans because at times they seemed to contain contradictory information, written on different shifts by the different shift nurses. How they were written, also confused Aroha because everything seemed very rushed and in hindsight one has more time to do this when a student nurse in comparison to a full workload of patients on a busy ward as a registered nurse. These situations are still ones that Aroha debates when faced with these scenarios in her present day situation as a Maari registered nurse.

As time progressed Aroha suffered from a chronic back injury which impeded her ability to function successfully in certain nursing situations such as having to lift patients. When 
Aroha received this back injury, she still needed to continue nursing because this was her livelihood, but with planning she was able to nurse in areas that did not require so much heavy lifting. She saved enough money to head overseas to countries such as Australia, Hong Kong, China, Canada, Scandinavia and the Philippines, which opened up a new world for Aroha. While in these countries she never worked as a nurse but while in China, she worked in an orphanage. This was a rather sobering experience and Aroha 'grew up' very quickly in this environment. She learnt to appreciate the nursing in Aotearoa when exposed to situations not of her tikanga and kaupapa.

When Aroha finally got over the travel bug she returned home to Hawke's Bay and applied for a registered nurse's position that was available in the acute inpatient psychiatric unit. It allowed her to continue nursing, as this type of work did not involve heavy lifting, so Aroha's chronic back problem was managed. Nursing in the area of mental health allowed Aroha to demonstrate her people's skills. She learnt a lot about people, particular Maaori while in this position. An opportunity arose when a position became available in the community and Aroha applied and found herself working in the area of Maaori mental health. This enabled her to practice from a Maaori worldview and utilise her reo Maaori, which was at a conversational level at that stage in her life. Aroha was encouraged to study at Te Waananga o Raukawa, which she enjoyed, particularly gaining understanding around Maatauranga Maaori and extending her reo Maaori. After a period of time she graduated with a Heke (diploma) in Maatauranga Maaori. The knowledge she gained she applied in her nursing practice. Aroha is a kaiawhina at Te Waananga o Raukawa and lectures in the Oranga Hinengaro programme.

\section{Events/Reforms}

When I posed this question to Aroha she commented that there were two aspects that had an impact on her which were challenging. These were Maaori students' hui and Kawa Whakaruruhau/Cultural Safety.

As a nursing student, Aroha attended the Maaori student hui which were held in various parts of Aotearoa. It allowed whanaungatanga to be developed between students and allowed them to express themselves in a Maaori environment which could not be done elsewhere. These hui made Aroha aware of the cultural differences facing Maaori nurses and the debates that arose from these discussions were stimulating and challenging. There 
were those Maaori nurses who were born and raised on their marae, surrounded constantly by whaanau, hapuu and iwi members. There were those like herself from an urban situation, with minimal reo Maaori and less knowledge on what they understood a Maaori worldview meant. Coming together in such forums allowed each one present to manaaki each other in a way that was mana enhancing. It also allowed the word culture and what it meant to be discussed allowing Maaori to have their voices heard (Durie, 1998) regarding things Maaori. Government took note of these comments and planning began to include the ideas expressed into policy and legislation. When reflecting on the progress made Aroha feels it was slow and when implemented showed lack of rangatiratanga by the Government.

Aroha found Kawa Whakaruruhau/Cultural Safety challenging and stimulating. The beliefs and values that the late Irihaapeti Ramsden (2002), identified was something Aroha believed was important for all nurses to understand. As a model it is deeply concerned with the effect of unequal resource distribution regarding nursing practice and patient wellbeing. It allowed debate and discussions to be part of her everyday nursing existence and at times became heated, but Aroha enjoyed this type of debate session. The theory around what Ramsden (1992) viewed as Cultural Safety, and Leininger (1991) whose focus was on Transcultural nursing was even more challenging for Aroha in the classroom situation. Aroha felt that the major difference between the two views was that Cultural Safety and Transcultural nursing were positioned in the anthropological and sociological definitions of culture and their boundaries, with the link being the concept of ethnicity.

These are the whakapapa and life-stories of Kim, Ani, Te Ata, Hineroa, Margaret and Aroha. Central to these six participants is 'being Maaori' and what that means for themand it is threaded throughout each participant's conversation, lending itself to the fact that 'who' I am and 'how I am' as being part of the kaupapa discourse. These conversations allow the reader to gauge and be part of this research study, in a way that they can bring their own analysis and interpretation to the whakapapa and life-stories that have been disclosed. 


\section{Summary}

When I began to interpret these whakapapa and life-stories, I noted central to each of these participants is 'being Maaori' beginning to emerge. In the next chapter, they share their stories about what are Maaori registered nurses' understandings of Maatauranga Maaori in relationship to nursing practice? And, how do they apply these understandings in nursing practice? So what can we learn from their lives in becoming and being a Maaori nurse in situations that are at times less than beneficial for them and those Maaori they were caring for.

The positioning of these six participants within the tuakana/teina concept reflects a Maaori viewpoint. The value of utilising a kaupapa that is subjective and holistic ensures that the participants are at the forefront of this research study. It allowed whanaungatanga to be embedded, which secured the fact that these participants would be confident that each one in order of eldest to youngest was protected in any given circumstance.

There were events/reforms, which impacted hugely on Maaori because of the constant changing by the Governments of the time. When one traces the progression of these changes they were rapid and at times confusing. One needs to note the many policy and legislation changes, which, at the time of inception were positive for Maaori providers, but compared to today, these benefits have been silently eroded away. This needs to be an area of concern for Maaori providing care for our people and the shift that this present Government is developing. Throughout all Government policy and legislation there appears to be a very narrow application in relation to Te Titiri o Waitangi and as such the struggle for all Maaori is to ensure this is not the case.

The introduction of Kawa Whakaruruhau/Cultural Safety in the nursing curriculum allowed the understanding to be gained around valuing the culture of the person. This as a model provided a pathway for all nurses to become familiar with how Maaori felt they needed to be cared for. On reflection and over time the many discussions and views held and changes implemented have resulted in a less then favourable outcome for Maaori. The participants indicate that this is an area of concern and we need to be firm and strong in our 
thoughts and ideas, that the care for Maaori is practiced from a Maatauranga Maaori continuum.

There is a great deal of likeness that surfaced during these conversations. Ani, Te Ata, Hineroa and Margaret whakapapa to Tuuhoe as an iwi and are fluent in te reo Maaori. All have been associated with their marae, spending time with those kaumaatua who played a significant role in explaining what 'being Maaori' meant. Kim and Aroha have gained insight into what 'being Maaori' means for them at different intervals in their lives. For Kim her journey began in earnest in 1985 with her association with Waikato Polytechnic and the Maaori associated in this organisation. Aroha was introduce to being Maaori by her grandparents who played a predominate part in this knowledge gain. Storytellers and storytelling were part of all their lives. Each story brought with it key role models within their practice and education such as whanau, extended whaanau, professional colleagues and friends. There were Paakehaa who played a predominate part in some of the participant's lives overtime. Kim, Ani, Te Ata, Hineroa, Margaret and Aroha do not think they are exemplars as nurses but they want people who read this thesis to learn from their experiences.

What effect has being married to someone not of their worldview had on these participants? Did having children from a mixed marriage become difficult to maintain a Maaori worldview? If one's parent is Paakehaa what effect did this have? What if anything impacted on them to continue believing in the kaupapa associated with this worldview? These questions and many others became a part of my everyday existence. All six participants 'recognise' and 'see' that being Maaori is different even though some have married into other cultures and produced children from these mixed marriages. They are aware of their positions in a society that is settled by Europeans and now other ethnic groups, because they become part of it, yet are also apart. They have seen and experienced aspects of being treated differently yet have become stronger and wanting to achieve more for themselves and others in their life. Without this exposure they would not be the Maaori nurses they are today. They all have a pride in being who they are and the changes within nursing have been huge, so that being who they are in this era is not detrimental - in fact the opposite occurs. 
'Being Maaori' for some of them may have occurred from the day of their inception, yet for others it was further down their journey. It is as Hineroa stated 'when caring for those Paakehaa in the nursing home I worked in, all I did was reflect back to my old people who I cared for in Ruuaatoki'. I did not question their colour, values and beliefs I cared for them from a Maaori viewpoint. Margaret, in one of our early conversations stated "a person cannot be who they are if they are not born of that culture". I have married someone not of my culture but he has adapted to my ways of 'being Maaori'. It is very evident in everything Te Ata does, from her mihimihi, karakia and waiata that she performs in all given circumstances, all done in te reo Maaori. It never became an issue in my marriage on how my children were to be raised. Ani in conversation indicated that caring for Maaori lent itself to 'being comfortable to include this type of practice into her nursing because it is who she is and who these people she was caring for are'. She applied this same thought process with those not Maaori.

It is also reflected in the comment Aroha made about knowing her tuurangawaewae which for her was not Ngaati Huia but Palmerston Road where she spent many happy times with her grandparents and whaanau members and the memories were such that they have stayed with her today. In Kim's circumstance 'where she is from is who she is' as 'being Maaori' came later in her life and has had a profound effect on her professional and personal life. It is also evident in the area of nursing as 'being Maaori', which all six participants have been attracted to in their lives. They may have gained experience and knowledge outside of their Maaori worldview but all have worked in a tikanga Maaori environment and made the transition with ease, because it is who they are. Their educational qualifications and contribution to education for Maaori have been undertaken in tertiary institutions not of their worldview, but they have then integrated this knowledge when becoming kaiawhina within the confines of Te Waananga o Raukawa. This has contributed I believe to 'who' they are as Maaori nurses because they bring this worldview to their nursing practice. Outlined have been their differences but how they go about positioning these differences is by the various kaupapa that become evident in their conversations, which will be disclosed in Chapter 5.

In the next chapter what has been disclosed regarding these six participants whakapapa stories has laid the foundation of 'being Maaori'. As a consequence what has emerged is that 'being Maaori' is 'who I am and how I am'. As a result a collection of kaupapa 
themes became obvious and it is these that will be explored from the life-stories that these participants have willingly conveyed. 


\section{Chapter 5}

\section{Life-stories: 'Being Maaori' is 'who and how I am'}

The justification to make the above statement - 'being Maaori' is 'who and how I am' has come from Chapter 4 and the disclosures in the whakapapa stories of these participants, Kim, Ani, Te Ata, Hineroa, Margaret and Aroha. They make this claim when they identify, locate and position themselves within their whakapapa stories by saying 'being Maaori' is 'who I am and how I am'. This then allows the carrying forward and the interweaving of 'being Maaori' is 'who and how I am' from their life-stories - or the 'what' and 'how' of the day-to-day practices that as Maaori registered nurses they incorporate into their nursing practice. As a statement, it indicates the strength of the participant's strong stance, from which to make this committement and to clearly indicate how they view themselves within a Maaori worldview. There are similarities but there are those dissimilarities, which have been indicated in Chapters 1 and 3, around oneself, their whaanau, hapuu and iwi.

In analysing and interpreting these conversations of the six participants, what I can state is that there is no single key kaupapa but a 'collection' of kaupapa that emerges from their life-stories. What must be understood by the reader is that this chapter needs to be focused from a Maaori worldview. To try and incorporate a Western viewpoint will not allow the essence of these stories to be obvious and the reader will then have difficulty absorbing what is being conveyed. The key kaupapa starts with the opening statement 'being Maaori' is 'who I am and how I am' leading to a collection of kaupapa being identified namely; whakapapa, whanaungatanga, te reo Maaori, wairuatanga, tuurangawaewae, manaakitanga and rangatiratanga.

This 'collection' of kaupapa themes, allows the embodiment of key sections of the participants' stories, to be disclosed while in conversation with them. To capture, engage and allow the surfacing and disclosure of these kaupapa, quotations and reference have been used referring to each individual participant's reply, while being mindful that it is reflective of their whaanau, hapuu and iwi. These sections belong to the six participants and are reflective of these Maaori women embedded in Maatauranga Maaori within their day-to-day nursing practice. The participants speak on behalf of themselves, their whaanau, hapuu and iwi and those tuupuna now gone before them. 
Each kaupapa has its own section. I have presented 'whakapapa' first as an insight into the participant's ability to identify and locate who they are as Maaori and the interlinking aspects associated with this kaupapa. The second kaupapa is that of 'whananaungatanga' and focuses on how this interlinks into whakapapa and the relationship ties it has with the participants. The third, is 'te reo Maaori', which is the primary language by which Maaori communicate, which has been identified by the participants, as being preferred as a medium in which to dialogue with those who access health services. Fourth, is the kaupapa of 'wairuatanga' that enables the participant to reflect on their belief in recognising the intangible essence that it brings. Fifth, is 'tuurangawaewae', which encourages these participants to recognise and allow the locating of themselves in a space or place they can call their own with the support of their whaanau, hapuu and iwi. Sixth, the kaupapa of 'manaakitanga' that shows the contribution of hospitality that these participants practice. Interlinked with this is the understanding around reciprocity. The final kaupapa of 'rangatiratanga' expresses the leadership ability, which comes in many forms and ways for these participants; within settings they have been exposed to and which they integrate into their day-to-day practices. These kaupapa are woven into each other and can be said to be 'interconnecting' kaupapa. They are interwoven and to view them separately, will prevent the reader from successfully understanding what they are trying to convey, because the significance each has with one another is important. This has been clearly identified in previous chapters of this research study, particularly Chapter 2.

Regarding the language of te reo Maaori, I will not translate anything written in Maaori as I have done in previous chapters, because to do so will diminish the embodiment of 'being Maaori' is 'who I am' and 'how I am' as a participant, especially when they have specifically spoken in their first language, without then breaking into English to translate what they are expressing. The wairuatanga of who we are as a people is reflected in the use of our language, which belongs to one's hapuu and iwi and is the 'life line' to one's survival as Maaori as a people. In reading and thinking around one's language, its value and its relationship to other kaupapa that identify us as 'being Maaori' is the poignant contribution of Jacq Carter written by Witi Ihimaera (2003) who contends: 
As part of our stay we were hosted at Takou Bay. It is a place where Papatuuaanuku hardly breathes and is silent so that she will not give her hiding place away. It is the place I came to know, 'I was Maaori' as opposed to being told 'I was Maaori'. It is the place where I was told all the stories regarding ourselves as a people. It was a place that I learnt to share and was given the honour to thank those who had hosted us. I had hardly started my thanks when I began to cry and I will never forget what Erana Wineti said to me, 'that's your wairua speaking'. For me the time spent, I learnt about 'being Maaori' and the value of our reo Maaori and the many transition one has to make

While reading Rose McEldowney's (2002) thesis, this became the key to unlocking how the participants 'voices' should be represented in this chapter, which is through the use of a different typeface, not used in the previous chapters. It brings a distinct and unique approach to the participants 'voices' that may not have been captured if not constructed in this manner. What I will also exclude is the use of italics for any Maaori words (in the preceding chapters all Maaori words were in italics) allowing the focus to be on the typeface mentioned for the participants 'voices'. Hence, in this section I will use Times New Roman, 12-point italics. In some situations I may use citations that have made reference to the particular participant, transcript and conversation number. For example, $K i m$, $i v 2, p .3$; or when the citation goes over two pages Kim, $i v 2, p p .3-4$. If the citation includes parts from different pages then it will be expressed as Kim, $i v 2, p p .23-5$. In some circumstances where I may have focused on one participant or their whaanau and hapuu member, I have not used citation so that the storyline may continue to flow without interruption.

In reality I share some of the participants' ideas about the notion of 'who I am and how I am' as well as the understanding around this as a kaupapa and I believe one needs to be 'true' to oneself, otherwise (to be authentic) within one's conversation will not occur. It is a criteria for establishing rigour as outlined in Chapter 3. A correlation has become evident between the whakapapa stories as a framework for this study and how the participants have presented themselves with truthfulness, in relation to their confidence 
about 'who' they are is 'what' they do in the world. These participants locate and lay claim to 'being Maaori' by saying 'who I am' and 'how I am' and 'this is the way I do it'.

It may be viewed as my prompting or guiding the participants in achieving answers that people may perceive as prearranged, because of the way in which I have outlined the research questions. I am mindful of this view, so I left the focus of the questions to be one of openness and have an uninterrupted flow, in which the ideas and thoughts of the participants can be such, that it allows their thinking and not mind to come to the forefront, when expressing these kaupapa. This was also the way in which Wheturangi WalshTapiata conducted her conversations referred to in Chapter 3 highlighting the value and honesty this brought to her research study. I gave a brief summary of what these kaupapa are and now I need to commence to link each kaupapa and what it reflects for the participants in their conversations as 'being Maaori' is 'who I am' and' how I am'.

\section{'Being Maaori' is 'who I am' and 'how I am'}

This, as an introductory statement, carries with it many ideas and thoughts in connection with 'being Maaori' is 'who I am' and 'how I am' as a kaupapa for these participants. This has become evident in their life-stories - from expressing their whakapapa connections as to 'who they are' or from experiences they have been exposed to while growing up; the stories told of their hapuu and iwi histories; mythology connected with their people; and, the interlinking of one's whanaungatanga ties that come with the 'knowing' about or incidents that have affected them in other organisational settings where they have represented 'being Maaori'. It then allows the claim to be made that there cannot be one kaupapa that drives these six participants but a 'collection' of kaupapa that are interwoven together to express what these participants are reflecting. For example, Aroha recounts her sense of 'knowing' as a child while being taught the value and understanding of the kaupapa of manaakitanga towards people by her grandparents. As a consequence, she cannot understand how those who say they are Maaori health professionals express themselves when caring for our people by placing restrictions on how many people can visit whaanau members who have travelled some distance, bringing with them kai and other necessary requirements. She crosses the line and breaks the rules, allowing all whaanau to visit, because those teachings of her grandparents regarding manaakitanga, influences and guides who she is, and why she does what she does for our people. 
There are numerous other threads that interlink with this and to those participants, and we need to recognise these as the criteria when reading this section. But, where do I begin? These kaupapa themes that are ever present in their manner and ways, have the tendency to suddenly appear in conversations with Maaori and these participants, which all interlinks and, so to begin this weaving of this whakapapa panel, the first thread will be that of whakapapa and its location within these participants life-stories. Before addressing this kaupapa I need to give an overview on how the participants reached this conclusion. Over the period of a year the participants and I each engaged in conversation whereby we would reflect and revisit the 'what' and 'how' focus of the research questions. Together we would summarise and then discuss these ideas and then expand further on this. What I had outlined in the life-story framework by the use of whakapapa as imagery - linking, reflecting and the reconnecting, these participants were demonstrating without prompting. When I posed the research questions to the participants', What are registered Maaori nurses' understandings of Maatauranga Maaori within nursing practice? And, how do they apply these understandings in nursing practice? I was met with mixed responses, Te Ata gestured with her hands and said

\section{I need to think about this more but keep talking so that I can respond}

$$
\text { (Te Ata, iv3, p.2) }
$$

\section{Aroha's response was}

I thought I had the answers but I am not so sure now, let me think

(Aroha, iv3, p.4)

Kim when re-engaged in conversation regarding the research questions, was concerned about the answers she had provided. She wanted to revisit this when we next meet. Margaret felt she needed to give more thought to the questions and Hineroa and Ani gave confident answers, first up, when asked. I was somewhat surprised at the response of one or two because I knew that we had prepared ourselves at the beginning of this research, when I engaged with each participant on what this study entailed, by kanohi ki te kanohi. On reflection, I do believe that because of their busy life-styles, they were distracted and did not come prepared to our subsequent conversation, but once focused they responded with confidence. When approached by those participants who needed more time, I then 
ensured when I repeated the question I made it clear I wanted to focus on their explanation and opened the conversation in another way. I was concerned it could have been the way in which I framed the questions that created this hesitancy or uncertainty.

What and how do you see Maatauranga Maaori within your nursing practice or is this as a kaupapa not part of your viewpoint

(Helen, iv3 with Te Ata, p. 4)

After their second and third attempt to answer these questions there was no need for further discussion, so we were able to move on in our discussions. It is time to visit the kaupapa identified by the participants, that being whakapapa and its location with the participants.

\title{
The location and identity of whakapapa
}

Whakapapa is the glue that holds us together and outlines the blueprint of one's tuupuna, both gone, present and for the future.

$$
\text { (J. Williams, 2000, p.2) }
$$

\begin{abstract}
All of the participants locate and identify themselves within their mihimihi by their whakapapa connections. As a kaupapa these six participants are familiar and comfortable with this notion, but how it is expressed, is, for one or two, dissimilar. If the reader revisits the whakapapa stories of the six participants, explanation has been outlined around 'being Maaori' is 'who they are' and 'how they are', which explains the similarities or dissimilarities. In Te Ata's case her first initial conversation was conveyed in te reo Maaori, whereby she commences with a karakia and then precedes to introduce herself:
\end{abstract}

Te whititanga mai o te raa ko te maunga ko Taiarahia. Ka hora mai nei a Taiarahia ngaa marae $i$ roto $i$ a Tuuhoe. Kite atu koe $i$ te marae o Te Rewararewa. Ka kauhoe atu koe i teeraa taha o te awa, ana kei reira te tupuranga mai ooku. Ko Ohotihi te marae. Ko Potiki te wharenui. Ko Ohotihi te kainga. Ko Te Otitepaa raaua ko Kuratake Makarini Whareteneti aku matua. Ngaa koroua me ngaa kuia $i$ te taha o taku paapaa ko Te Keepa Rongotoariki Keepa Te Ahuru me Kahoki Haeata. Ki te taha o taku whaea kookaa noo Mahunga ia. Ko Ngai Taawhaki te 
hapuu, ko Taawhaki te tangata. Ko Te Paora Paora te koroua ko Hora Kaipoo taku kuia. Ko ahau te pootiki a raaua, a Te Otitepaa raaua ko Kurataka Whareteneti.

and Te Ata ended with her waiata, and when she sang I could feel her tuupuna standing with and beside her and the wairuatanga became evident when this occurred

Matatua te waka o ngaa tuupuna

Te tangata o runga Toroa

Te wahine ko Wairaka naana hoki raa

Te koorero Whakataane au i ahau

Te koorero Whakataane au $i$ ahau

$$
\text { (Te Ata, iv1,p.l) }
$$

When the same question was presented to Ani and Margaret, I was not surprised at the answer. Both acknowledged their whakapapa connections in their initial conversations by expressing this in their mihimihi. They did not mention their Paakehaa ancestry and this was due to many reasons but the answers mirrored by these participants are reflective of there belief in 'who' they are as Maaori. Ani acknowledged herself in this way

\author{
Ko Taiarahia te maunga \\ Ko Ohinemataroa te awa \\ Ko Te Mahurehure te hapuu \\ Ko Te Rewarewa te marae \\ Ko Rangi Moaho raaua ko Kuramihirangi ngaa whare tuupuna \\ Ko Tumatauenga te whare kai \\ Ko Te Purewa te tangata \\ Ko Tuuhoe te iwi
}

$(A n i, i v 1, p .1)$

Margaret commenced our first initial conversation with the following mihimihi, which reflects and identifies her 
Ko te maunga tuatahi ko Whakapuanaki.

Ko teeraa te maunga tuuturu o te iwi o Ngaati Kahungunu ki te Wairoa.

He maunga tapu teenaa. E rere ana te wai ko Ruakituri teeraa awa.

Ko Eripeti te marae. Ko Te Paerau te hapuu. Ko Ngaati Kahungunu te iwi. Ko teeraa te waahi i tupu ake ahau engari ko teeraa te waahi o tooku kuia whaangai oo tooku paapaa. Noo Tuuhoe taana paapaa tuuturu.

Noo Waikaremoana ia engari tupu ana ia i roto i te waahi o Eripeti.

Noo Ruuaatoki toku maamaa. Ko Te Rewarewa tana marae, ko Ohinemataroa tana awa, ko Taiarahia te maunga. Ko Tuuhoe Pootiki te tangata, ko Tuuhoe te iwi. Ko Margaret Jackson ahau. Ko Norman Rangi Jackson Erueti tooku paapaa. Ko Mirirau Paenga Biddle Jackson tooku maamaa

(Margaret, $i v 1, p .2)$

When directing the same question towards Kim, the answer received is that she locates and identifies herself not only with her Maaori linkage but that of her Paakehaa connection

I have my Ngaa Puhi link and my Ngaati Kahungunu side. But I also have Scottish, Welsh and Danish heritage that make me who I am today

(Kim, iv1, p.1)

Another slant on this, which Kim expressed, is that the use of whakapapa as a backdrop imagery challenged her and it enabled her to chart her nursing career in a way that made sense to her. It made me reflect on what I had done, how I had done it and who was involved in the whole processes. It is an innovative way of reflecting on one's nursing practice. Kim felt that this was a valuable tool to be used in a way to engage with anyone undertaking research of this dimension.

Kim on reflection felt that she had found it a challenge understanding what it meant being an 'urbanised' Maaori. By her father moving to the city of Wellington because of work requirements and studies, they became the products of this movement. In doing this journey I hadn't thought about this as a question regarding who I am, but it is part of me and what I do is connected to this, so it has made me reflect and made me take on board 
this notion. I would never have considered this until being part of this study, which I acknowledge and accept.

In Aroha's situation she wanted to think on this because as time has evolved how she usually presents her mihimihi is something she wants to change and present in another way. But what she did reveal in her initial statement was the whakapapa connections of her grandmother and grandfather

My grandmother is Ngaati Huia, ki Poroutawhao and my grandfather is Waikato from Kaawhia and he belongs to the Ngaati Toa line that stayed in Kaawhia not the Ngaati Toa who went with Te Rauparaha to Porirua or Kapiti

(Aroha, ivl, p.2)

This acknowledgement by Aroha is to the importance of those ties to her grandparents because as she conveys

I will introduce myself and I will say who I am, but that means nothing, and then I say who my grandparents are and then everyone knows who I am. It happens time and time again and then all of sudden I become whaanau forever

(Aroha, iv2, p.2)

Another aspect that emerged from these conversations with Aroha is that it has now made her think about her whakapapa connections with Ngaati Huia. I need to reconnect with this hapuu of Ngaati Huia, after having reflected on my statement around them. It is important that I do this, because there is this link I have, but I have not done enough and I will make the effort to do this.

In Hineroa's case her mihimihi revealed that her whakapapa linkage, allows the acknowledging of her old people in a way that reminds her 'being Maaori', is 'who I am'. My grandfather made sure I knew who I was and this was conveyed in te reo Maaori and so the whole essence wasn't lossed on me. Those philosophies associated with this worldview were part of me and are still with me today. 
The six participants have been truthful in the locating of themselves within their whakapapa. They have not suppressed themselves when disclosing this as 'being Maaori' is 'who I am' and 'how I am' which embeds them in the way they view the world. This is the 'blueprint' that they carry for the rest of their lives and they are committed to this identity about themselves. Hence, their active engagement and open honesty in wanting this kaupapa acknowledged in a way that is applicable to them. It indicates that the desire of those being cared for in health settings should be allowed and encouraged to identify and locate themselves by their whakapapa. The first area of focus should be on the admission form, which recognises one's hapuu and iwi concluding with a person's name. This then can be used as data to collect the information around where these people are from, how many actually are from the $i w i$ in which the health setting is positioned, and so on and so forth. This data then can be used to assess funding for Maaori health provider services and the Crown may want to reflect on how this data can influence their decisions around areas that need to reflect a wellness and healing kaupapa, which then needs to be recognised, so research can be conducted to produce positive outcomes.

\section{Whanaungatanga as a collective focus}

The process of weaving people together is one of the major elements of whanaungatanga, which brings together those who can help solve a problem.

(Bishop, 1996, p. 233)

In the previous section on the kaupapa of whakapapa, I presented the notion around the locating of the participant being driven by the sense of recognising who they were inclusive of those past and present. It lays the foundation around why we do the things the way we do, as Maaori. It then interlinks into the kaupapa of whanaungatanga, because without the recognition of whakapapa, one cannot develop 'relationships' or 'ties' with people to ensure that the action needed to ensure care, is being reflected appropriately. It needs to be positioned from this stance.

Looking back on the whakapapa and life-stories of each of the participants, it is evident that in their personal and professional lives, these as a kaupapa were predominant. At times they did not realise they were doing it, as it was a natural ingrained way of behaving 
towards people, whether they were Maaori or Paakehaa. Margaret pointed out in her initial conversation when we were discussing this as a kaupapa that reflected her, that

I was not prepared for the lack of whanaungatanga exhibited by people when I came to live in the town. I was so used to people from Ruuaatoki displaying whanaungatanga to each other. In the town, people brought their wood from the garage, whereas back home, whaanau would all get together and support each other with the cutting, collecting and depositing

(Margaret, iv1, p.2)

And as we progressed with our conversations Margaret referred to the personal aspect of whanaungatanga regarding her whaanau

Sometimes my whaanau forget to express this in what they are doing when we are around each other and I have to remind them about this ... I suppose that is what happens when some drift away from who they are as Maaori or it is the 'taken' for granted attitude that comes with the 'knowing' about

(Margaret, iv3, p.2)

Ani expresses this kaupapa when she talks about the way in which the whole hapuu 'collectively' work together when crops are to be harvested in and around Ruuaatoki

When the harvest of the crops was ready - this is when the riwai was ready to be te hauhake, they all came to work this

(Ani, iv1, p.2)

And following on from this Ani recalls that as a hapuu

The closeness and the kaupapa of whanaungatanga, which went further then the single whaanau unit it went to the hapuu and to the valley. There was a healthy rivalry amongst the hapuu, which is still there today

(Ani, iv1, p.2) 
In regards to taking this kaupapa with her in her professional practice, Ani has expressed these thoughts

I do not relate to someone as an individual but through whanaungatanga. In my work I take a whole lot of other people with me and that's where my strength comes from, knowing about whanaungatanga and the value it brings

(Ani, iv3, p.6)

Whereas, Hineroa expressed how she felt when caring for people within her nursing practice by the use of the kaupapa in this manner

When it came to looking after these old Paakehaa men who were terminally ill, I would look at them and think in my mind, I need to care for them like I would my old people back in Ruuaatoki. How else would I do this but by expressing whanaungatanga. Bro, I don't know anything else but this type of behaviour towards people

(Hineroa, iv.3, p.4)

In Te Ata's circumstances whanaungatanga was an important kaupapa throughout her period of nursing practice and still is today. This kaupapa has ensured that whoever she is caring for when the terrain becomes difficult, the 'collective' support of the whaanau is important for the health and wellbeing of the person and becomes a vital thread to ensure this occurs

When I was in situations where I could sense that the person been cared for was not progressing well, I knew that I would be able to call on the whaanau to assist in achieving wellness, because the kaupapa of whanaungatanga had been established from the beginning. It's important that this is done otherwise you will not achieve a positive outcome

(Te Ata, iv.3, p3-4) 
Another viewpoint conveyed by $\mathrm{Te}$ Ata is that when she leaves the area to take up a position somewhere else as a nurse, when she is passing through these areas, she ensures that she visits people whom she has cared for

Even though I have gone, it's important that you acknowledge these people and you always ask those vital things about how so and so is, and that is when you share. You hear "oh didn't you realise mum's gone". I say "I'm sorry" but at least you still acknowledge that. This is whanaungatanga for $m e$

(Te Ata, iv3, p.7)

For Aroha this as a kaupapa is where she is aware that those kinship ties are important when caring for those who identify as Maaori in health settings. For her it does not only mean that it is the 'kinship' ties that bind you and it does not necessarily mean those whakapapa connections, it can mean something else as she explains. The experience Aroha recalls is that a particular whaanau had come from afar and in conversation, mention was made of people who are familiar figures in the community including her grandparents. The response from these whaanau members was one of acknowledging those people mentioned and this opens the door for relationships to begin. As Aroha relates

Whanaungatanga is about whakapapa ties, but it's also about people you grew up with and your whaanau have contributed to in some way to whereby this as a kaupapa of whanaungatanga is developed and engaged in. It opens the door to a whole lot of possibilities but more importantly whanaungatanga has been established through the actions of your whaanau towards people

(Aroha, iv2, p.2)

This then leads to a more 'supportive' positioning for all involved in the care of the person which includes the 'collective' and not the 'individual' as the focus. Even though this may be the first time you have met each other, but it had been the actions of your own whaanau to others that is not forgotten, and allows the kaupapa of whanaungatanga to be expressed. In my particular case the value and importance of whanaungatanga was evident when a hui had being organised recently to have all the hapuu representatives there. To capture those 
moments, the use of a video camera was utilised and the ability to capture one's comments, expressions and gestures is now available for future generations to observe and digest. These will never be lost, as sometimes these moments cannot be captured when one is trying to do this with photographs. The kaupapa of whanaungatanga was evident on this occasion (M. Selby, 2006) and this action supports the stance expressed by the six participants in their whakapapa and life-stories.

In conversation with Kim she makes references to the support from the kaumaatua that whakapapa to the iwi in which she practices at present, as being the driving force in the recognition of whanaungatanga. As she indicates

I am not from here, so the development and understanding of whanaungatanga will not be achieved unless those kaumaatua who are from here are at the forefront of this being recognised

(Kim, iv2, p. 6)

By raising this as a kaupapa, the six participants created a way forward that offers a solution to envisaging what care can be like when demonstrated from the notion of whanaungatanga. It positions those being cared for and by whom in a positive place ensuring that the 'collective' is the 'voice' heard and not just that of the 'individual' which at times is the predominant way in which care is maintained for Maaori within health settings. What these participants are expressing is that there is another avenue to venture into and ensure care is provided from a kaupapa conducive to 'being Maaori', which then includes one's hapuu and iwi.

\section{Te reo Maaori is our taonga}

Our marae is our principal home

People are our wealth

Te reo Maaori is our taonga

Self determination

(Whatarangi Winiata, 2004, p.4) 
Recognising that te reo Maaori is our first language and as contended by Whatarangi Winiata 'te reo Maaori is our taonga' reinforces what these participants discussed in their conversations and that they believe te reo Maaori should be recognised as a medium of assessing our people when in health settings. As I have previously mentioned it was reinforced at a hui held at Ngaatokowaru marae by all those participating when this question was raised. Why then has te reo Maaori not being given the acknowledgment it deserves as part of the kaupapa of any health organisation as a means to gain knowledge about those who we are caring for. It would enable the mauri and mana to reside with the person being cared for, inclusive of the whaanau themselves and that of the Maaori health professional, providing this dialogue. The participants are advocating that te reo Maaori be positioned in such a way that as a means of caring, it is a recognised means of communication. The conversations produced inform the actions that are taken when some of these participants are faced with this situation. A willingness needs to be demonstrated by the Crown organisations that have the control over what does or does not occur in these settings, and, as such, should set the precedent that this is a requirement for all health organisations to become familiar and comfortable with, and to recognise and endorse those Maaori health professionals, who have this skill to communicate with our people in the language they understand, namely te reo Maaori to be a means of assessing our people.

Te Ata identified those of her colleagues who could not speak te reo Maaori and who were also not supportive of this being included in our people's assessment, but this certainly didn't deter her. In fact it made Te Ata more determined to use the language of te reo Maaori. She commented that

There has been a movement for some time by Maaori nurses to have te reo Maaori recognised as a medium to care for our people, but those in position of influence have ignored this, preferring to focus on the English language to converse and assess in

(Te Ata, iv3, p.6)

A further conversation with Te Ata revealed that in conversation with kaumaatua who are asked to describe or explain certain Maaori models of care they cannot do this in English. We only know how to do this is in te reo Maaori because how we visualise what is wanted of us, we can only do in this manner of communication because that's how we were taught 
by our old people. It loses its whole essence when we try to explain in English and then we have to pause and think and we become unfocused.

In an account written by Mason Durie (2003b) he supports the stance mentioned:

The use of te reo Maaori in formal assessment, family therapy and counselling should be a readily available means of communication.

In Margaret's situation, the conversation focused around the research question posed, and she firmly believes that te reo Maaori is one of the keys to unlocking caring for Maaori whose first language is this

If I was given the opportunity to plan my own setting for caring for our people, regarding my own iwi, I would not have a hospital as in the physical sense but I would provide a mobile unit consisting of people who whakapapa back to our iwi, highly qualified and skilled whether it be health professionals, nurses or doctors and care would be provided in their homes. Our people from back in this small area have other responsibilities and the healing and caring needs to be done in their own personal space and we would provide that. And if it means our communication is in te reo Maaori, we then assess in the language our people understand, because we are familiar with each other and comfortable in each others space in 'being Maaori'

(Margaret, iv2, p.2-3)

In Ani's case, over the years of nursing our people, she recognises and supports the stance that te reo Maaori is our language as 'being Maaori' and as such deserves the recognition

Because I know the Maaori people well who I care for, I know they are more comfortable expressing their concerns on what is ailing them in te reo Maaori. It then becomes a way in which I gauge what is ailing these people

$(A n i, i v 3, p 2)$ 
Hineroa, in anything she does, her first language is te reo Maaori and she says

Bro, te reo Maaori is my first language and every opportunity I get I use it. It is a way of communicating with our people that brings positive results

(Hineroa, iv3, p. 4)

The reaction from Kim was a very supportive stance whereby she fully supported those with te reo Maaori being able to converse with our people (when dialoguing with them) in any given situation that they may be exposed to while in nursing practice.

In discussion with Aroha she acknowledges the value of te reo Maaori as being part of the care provided to our people. It allows the opportunity for our people to be in control of their care when expressing it in their first language. The reaction from them is instantaneous, you see a different person emerge

To be able to dialogue in te reo Maaori, whether in everyday discussions or with our people who need our support when admitted, changes the whole way in which care is demonstrated, through the acknowledgement of the language being expressed

(Aroha, iv3, p.3)

Aroha also believes that we have become too business-like and clinical in our approach to our tangata whaiora because of how the assessment processes have been framed. If we, through te reo Maaori, can achieve a more subjective way of gauging information when clinically assessing, then we should be using this to reflect a positive outcome for all involved in the process.

Creating an awareness of the importance of te reo Maaori as a medium of communication for our people and those who care for them, is a positive step forward to optimum wellness being maintained. These six participants embed and position themselves within these lifestories and particularly the experiences revealed to them by our people in regard te reo Maaori as a means of communication. It is something that should not be ignored and as a means of contact should be given top priority of endorsement. This then will ensure the survival of Maaori as a people by contributing to their health and wellbeing. 


\section{Wairuatanga as a spiritual kaupapa}

All people are born with a wairuatanga. They have a soul that is part of who they are.

(Barlow, 2003, p. 152)

A desire for a clear understanding around this as a kaupapa was identified by the six participants because to assume Maaori health professionals have an understanding cannot be taken for granted as these conversations reveal.

Te Ata, in our initial conversation, exhibited this type of behaviour, which I do believe she was unaware of. This is because I feel that it comes with 'being Maaori' and it is "what she does' is 'who she is' and this has been through the development and nurturing done by her old people, since the day she was born. Without any 'awareness' about this, she expresses and embeds herself with her old people in her waiata, the sound reverberating in the room was 'spellbounding' and sent a shiver up my spine (I can assure the reader I am not the type of person who indulges or looks for this type of behaviour). In our third conversation when her kuia was present, this kuia voiced an opinion saying

How come I don't see this side of you when we are out and about with people in whatever situation we are in ... I know that this is with you, because of how you were brought up... But why hide it

(Kuia, iv3, p.2)

Te Ata's response did not surprise me because on more than one occasion I have had the privilege of 'knowing' her for such a long time, she never fully reveals herself unless she wants to and to whom

Because you are around me all the time you don't notice this because it is the way I am and you were part of my upbringing. But it is also about being in tune with oneself and when the occasion presents which has happened in this situation, I expose myself in a way to someone who I feel will acknowledge me for 'who I am' and 'what I do' as 'being Maaori'

(Te Ata, iv3, p. 3-4) 
In expressing herself in this way, I feel the true 'essence' of 'being Maaori' is what I had witnessed with Te Ata. 'What she does' is 'who she is' and at that precise moment in time, I endeavoured to capture what $I$ had just experienced on paper and hopefully I have done justice to what I observed.

Ani's view on this is when our men are performing there whaikoorero in their actions, facial expressions and in particular their use of te reo Maaori and the way they express the stories associated with the event, Ani believes the wairuatanga associated with what is being demonstrated is occurring. It is also present in the singing of the waiata performed by the women and the uniqueness that becomes obvious when this is undertaken. It is this intangible presence that is not visible but if one is attuned to this it becomes obvious to them depending on the circumstances.

As Margaret and I progressed with our conversations the kaupapa of wairuatanga became obvious. She reflects on her experiences with the old people whom she knows from Ruuaatoki, who are practicing Ringatuu. If a Nanny is admitted to the hospital and they want to disclose their religious beliefs, health professionals need to consider that

To find out if the Nanny who is lying in the bed, who is letting someone know that her wairuatanga is not good, we need to take note of this as it can impact on her recovery. Her religious beliefs in the Ringatuu faith carry influence and impact on her wellness

(Margaret, iv3, p. 5)

If health professionals, who are caring for this kuia, do not understand the value around her religious beliefs, which impact on her wairuatanga, then the chance of a wellness perspective being achieved, is not possible. The recognition of one's religious beliefs, which include karakia, is one of the most fundamental differences experienced between Maaori and the scientific approach to health. It is important that all health professionals whether Maaori or Paakehaa should be trained and become familiar with such thoughts (Durie, 2003b) so that those Maaori accessing health services achieve maximum wellness and wellbeing. 
Margaret reflected on her behaviour and how she believes that wairuatanga was a part of the reason why she did what she did under the circumstances. While a student at Te Waananga o Raukawa, I had an uncle attend the Maatauranga Maaori programme. He had given me this book, which is the history of their marae and suggested that I leave it with the library for others from their hapuu to access. I got as far as opening my car boot, looking at this book and closing it and saying to myself, this book doesn't belong in this library it belongs somewhere else, and so I will keep it with me until I know and feel that place. On returning home and after some time she saw her uncle and informed him of her decision and he smiled and said $I$ understand. Till this day this book is with Margaret and when whaanau want to access or read it, it is returned back to Margaret's safekeeping. One day when the time is right it will be returned back where it belongs.

When this as a kaupapa was discussed with Aroha she conveyed it in a way that reflected what her grandparents had brought her up to believe

My grandparents developed my understanding of wairuatanga and this was through the lens of Christianity. We were told to 'refer' to the lord if this was something that came into our vision and so I have carried that advice with me

(Aroha, iv3, p. 3)

When reflecting on Aroha's comments' I found myself thinking about the advice of my mother who would say that our old people did things to protect us so that no harm would befall people. I do believe this is what is being portrayed by the actions of Aroha's grandparents when this advice is being expressed because to divulge into areas that Maaori consider could do harm then good, this becomes the way forward to protect a person.

For Kim the conversations around her life-story and particularly the kaupapa of wairuatanga brought back many memories for her. One particular event involved her father and his death, which she has never disclosed till now 
When my father was on his last part of his departure, his body glowed like there was a light inside it and at the same time his grandchildren where in the room and they witnessed this and actually stepped back from his bed. It's a memory I take with me and this reminds me, what I believe wairuatanga means

(Kim, iv4, p. 5)

Another incident Kim recalls is when visiting people she knew who lived by the sea near a harbour entrance. She wanted to visit a certain spot but to get there she needed to cross the harbour, which they did at low tide. Her companion was a young eleven year old boy, named Billie. While they were crossing the waterway across the harbour young Billie commented 'Kim can you see the sentinels' 'our journey will be safe'. Kim replied "Oh were you concerned that we wouldn't be safe Billie?". She never questioned him openly about what had been said but thought that this young boy has this sense about things that is way beyond her thinking and he belongs to another world. I knew he was different. When Kim glanced up while walking and the residues of the harbour were in front of her she noted that there were these black swans in a formation resembling sentinels gliding along the water and then in that moment did she identified with what this young man was referring to in the way he viewed the situation.

Kim also remembers a time when she was part of a group who was listening to Hirini Meads and what he said about wairuatanga, be careful that you don't become too tapu because if you think that this enhances your wairua, it wont. When Hirini made this comment Kim didn't give it much thought at the time but on reflection she now understands the importance of this statement and what it means.

When Hineroa was outlining her experiences of nursing the young Maaori man with his motor vehicle injuries, she sensed and felt that something was missing in regards him gaining optimum wellness. I do believe that she noted with him being mokemoke that his wairua was becoming low and this needed to be replenished and to achieve this could only be through whaanau participants and the relationship this brings with it in relationship to this kaupapa. To be able to explain this to the medical and health professionals not of the worldview of Maaori would have been difficult. So Hineroa acted in a manner that she felt would provide a solution to what was occurring and it was interesting to note that Te Ata 
made the same comment in conversation four regarding someone she was nursing. His mokemoke was unbalanced and out of synch and intuitively I knew something was wrong. So I had to address the situation with his whaanau.

When an official occasion is presented on one's marae, as a kaupapa, wairuatanga is aptly referred to by the women when the karanga call is being made 'Hoki wairua mai i ngaa tuupuna'. In this way the women are acknowledging those spirits close at hand, which is the spiritual dimension Maaori refer to in the kaupapa of wairuatanga. Our people say they feel 'uplifted' when acknowledging this but there are also others who are troubled by this as a notion. In these cases the people cannot come to terms with the belief system reflected by Maaori. Because for some this is too real and their images are of ghosts that plague them throughout there lives, instead of the positive thoughts that are portrayed from this particular kaupapa (Meads, 2003). However, as the six participants indicate they have 'lived' with these beliefs and these are reflected in their carvings, stories, songs and weaving, which all tell stories about their tuupuna in a way that indicates 'being Maaori' is 'who I am' and 'how I am' in respect to the kaupapa of wairuatanga. In health settings what has been earlier referred to regarding the comments of wairuatanga and its connection to the spiritual world, would result in a person being referred to the psychiatric unit. When in reality all they are doing are relaying their beliefs and values, they have been brought up in, which can be misconstrued and misinterpreted in a way that leads to misunderstanding and misguided diagnoses. Other indigenous cultures have a belief system that reflects the 'spiritual' awareness of people for example Heiss, (2001), McLeod, (2001) and, Moses, (2001) all advocate the importance of understanding this as a notion.

\section{Tuurangawaewae as a place to stand}

A place to stand, or a place to complement a personal identity and lead to a greater sense of purpose and continuity.

(Durie, 2003c, p.79)

In our continual conversations the advancement of tuurangawaewae for the participants were expressed and viewed in a way that mattered to them as 'being Maaori'. They believe that as a kaupapa and what it entails, is not understood, therefore its value is not noted by health professionals whether they are Maaori (some Maaori do not have an 
understanding around this as a kaupapa) or Paakehaa. Hence, it is important that these professionals have an insight into it as a kaupapa and how it can be effective in gaining a wellness result for our people in health settings.

In our second conversation Aroha presented her view on this as a kaupapa, explaining that she understands about the customary application around tuurangawaewae but for her it is reflected from the contemporary viewpoint she holds

For me, my tuurangawaewae is Palmerston Road where my grandparents made this house and the land it was situated on as 'being' here for me. Happy memories and events occurred there with my whaanau. My grandfather had his large vegetable garden out back, which provided food for everyone. Along the street where other Maaori whaanau I knew well and this house and their houses became our meeting places

(Aroha, iv3, p. 2-4)

In our second conversation, Ani and I discussed the relationship of various kaupapa that had impacted on her as a nurse. She recollects the account of how she took solace in reading the views of Ranginui Walker in his column of 'The Listener' regarding anything Maaori. This gave her strength when at times the 'going' got tough in nursing. It reinforced her belief in 'being Maaori' because the contents of the work written reflected these views. One account of the kaupapa of tuurangawaewae comes to mind for her and this was in relationship to nursing and where she found herself located physically - even today - which is at Mangaweka. Ani identifies with this physical space and considers that

This became my tuurangawaewae as far as my nursing was concerned. All of my nursing practice was situated near or around here, so it became the hub of my professional existence

(Ani, iv3, p.2)

Further into our conversations I noted, that when in the right space and place, Ani's ability to allow the dialogue to flow around anything Maaori, became predominant. When I mentioned this she remarked about her mother: when I wanted to hear, to know something about her or about us, I could never just ask her because she had to be in the mood and 
had to be able to put herself in that place. So this is where the koorero comes in. So you have to put yourself into that place, to be able to talk about that thing. So that's what I am going to say to you now about what we are talking about. It requires a journey into there, into that atmosphere, into that time even, to be able to express it and, to articulate it as well.

As I indicated in Chapter 4 in relationship to Ani, there is this intangible thread that $I$ as the researcher could not put my finger on, but with further revelation by her this intangible thread now makes sense to me. How she has described her mother is, how I believe, Ani reflects who she is and how she is as 'being Maaori' when contemplating answers to the research questions. Ani believes this is the way the kaupapa will flow and be expressed in a way that makes sense to Maaori. For some it does not come naturally and everything has to be right for it to happen so the koorero may flow as in Ani's situation.

For Kim her tuurangawaewae as indicated in her initial conversation started back to 'where I am from' and this could mean the whenua of Ngaa Puhi, or the house she had known in Wellington or the trip she took to England to reconnect with those Paakehaa ancestors

I hadn't placed a whole lot of value on one particular space to locate myself because I have so many to think about

(Kim, ivl, p.3)

or it is as Kim's father has reminded her throughout her life, remember where you are from. If you are not from the place you are working in, then you cannot claim this as your own.

A particular event that made Kim aware of her tuurangawaewae was when a whole bus load of people from Ngaa Puhi attended her father's tangi. Her main concern was that they had never been back home to live amongst her father's people and had they lost their future link. But the words reflected by the kaumaatua after the formality of the whaikoorero have stayed with her. He said 
Don't forget to come home; you will always have a place back there because this is your whakapapa links, which is a place you can call home and stand on without having to worry if it is yours to be on, because it is

(Kim, iv4, p. 6)

Kim reflected the same idea that had been expressed by Aroha, that people don't associate me as such until I mention who my parents and their grandparents are which connects me with my tuurangawaewae through whakapapa. This happens on a regular basis even at the age I am today. But that's they way we do things as 'being Maaori' and I don't have a problem with this when it occurs.

At our fourth conversation Margaret proceeded to explain what she felt the kaupapa of tuurangawaewae reflected for her. I always remind my children where their tuurangawaewae is, which our marae is. My parents are still there today. I tell them it is not Flaxmere where we live at present, but back at Hiripiti. If I don't explain this to them they will assume it is our current place of residence, which for me it isn't. I make sure in their mihimihi they reflect this. But another aspect I need to mention is that I need to take my children back to my parent's other side so they know both sides of their whakapapa. I myself have only been there when my job required it as I had a responsibility to venture back to this other marae of my parents, otherwise I wouldn't have gone, but this study has made me more aware that I need to do this for my children.

In trying to capture this as a kaupapa Te Ata notes that tuurangawaewae means many things for people and she feels the same. I know where I am from and I can locate myself in that place and space but I can handle that and I don't worry in this regard, if others disagree. The knowing about is important for our people because it is as a kaupapa, a link that cements a person or persons in a place they can claim as their own. It is a kaupapa that health professionals have less understanding around because it's not used a lot in discussions but we need to recognise and re-introduce it in our everyday practices when the occasion arises. 
When engaging in conversation with Hineroa she explains

Tuurangawaewae is so important to me and to those old people who have guided me in my thoughts on understanding this as a kaupapa. Bro they made me realise how important it is to me and my whaanau

(Hineroa, iv4, pp4\&5)

The ability to be able to locate one's self in space that belongs to you is a soothing and healing moment for some people. It allows the thought that you have somewhere to call home, and no one can actually take that away. This is may be because it holds fond memories or where your parents or grandparents allowed you to be who you are as being Maaori. Whatever the given situation it is one that you hold dear to your heart and these participants are saying that people who are being cared for should have the right to express and allow this kaupapa to be recognised without people forming an opinion that isn't understood from the worldview of Maaori. It is important that this is recorded whether in their history notes or a place situated on their admission sheet whereby research data can be found leading to positive outcomes for these people. One's tuurangawaewae also has significance for those Maaori nurses as this is a space or place they can locate themselves, as far as who they are nursing, and who may identify through whakapapa to them. They can relate to these people because of the whaanau, hapuu and iwi relationship that this kaupapa and those kaupapa mentioned, may interlink them.

\section{Manaakitanga and the expression of hospitality}

The tikanga of manaakitanga - nurturing relationships, looking after people, and being careful about how others are treated

(Meads, 2003, p. 29)

I have presented to the reader that these kaupapa are interwoven and interlinked and as such are part of a 'collective' and this is no different for the expression of manaakitanga. To express this kaupapa to our people we need to ensure that we understand what it means and how it can be applied within our nursing practice. This I believe has best been reflected by the words used by Meads in the opening statement to this section. 
The kaupapa of manaakitanga is a notion that cannot be evaluated. Only outcomes can maintain its effectiveness. According to Aroha at present in Kaupapa Maaori services, restriction is being placed on how many whaanau may visit. These whaanau may have travelled some distances to visit their member, bringing with them kai or clothing, but to their dismay have being told that only ' $t w o$ ' members of the whaanau can stay. To express manaakitanga in this manner is 'foreign' to Aroha, because she has been taught by her grandparents no restriction is placed on how many people one provides hospitality to. When people who write policies and procedures are not of a Maaori worldview it becomes distorted and misinterpreted, resulting in a 'band aid' kaupapa being implemented. Those health professionals (both Maaori and Paakehaa) respond in a way that does not express the kaupapa of manaakitanga, resulting in a negative experience had by all. This is where the evaluation processes identified cannot withstand the scrutiny it reflects. The only way we can gauge results from the expressing of this kaupapa is by understanding how the outcomes are met and this is one incident where it won't be attained if not expressed in the mannerism demonstrated by Aroha.

When Aroha reinforces the value of manaakitanga instilled in her by her whaanau, which she carries forward in her nursing practice it is expressed in this manner

Manaakitanga is the value of helping and wanting to care for someone else, clients and their whaanau. But you have to be wise about that because sometimes, advantage will be taken, but I think it's always important to have that humbleness and also that heart of caring, wanting to share, wanting to help and wanting to serve

(Aroha, iv3, p.2)

For Margaret, manaakitanga as a kaupapa is not hard to express to our people if you have an understanding of this. But if one doesn't then problems occur. As in the case of this as a kaupapa being expressed by the nurses' organisation to whom she contributed a great deal of her time and energy 
If felt that to expose and give of myself to a group of people who had no inkling of what it meant to be Maaori, was a waste of time and energy. So I held back and knew that if I expressed manaakitanga to them there would be no reciprocity

(Margaret, iv1, p. 4)

While reflecting on the participants' conversation, Te Ata made the same reference earlier as Margaret had in regards to exposing and expressing oneself from a Maaori worldview and how this will be received by those not of this worldview. People struggle to comprehend but this can be overcome if only people would say to each other 'I don't know what it is you are saying' can you 'please help us to understand' but of course in most situations this does not occur and we go about our everyday nursing practices without communicating with each other. As Whatarangi Winiata (2004) contends

With all the good intent in the world, Paakehaa have tried to tell us how to live in our own world as Maaori, and they haven't being successful in achieving their intended goals

A recent experience Margaret recalls is the poowhiri they conduct within the area she is presently employed. Everyone gets together to welcome visitors but what I witness is not correct in regards manaakitanga towards these people (particularly Paakehaa). I know it's wrong because of the way I have been brought up, but I still participate in this activity. We would not do this back on our marae, so why do we practice this kaupapa the way we do. It's a band-aid measure to suit the occasion, which is wrong. If we demonstrate this kaupapa then we do it properly or not at all.

Included in these experiences of Margaret's was the setting up of their kai area for the visitors and in order to manaaki them. But what became evident was that the Maaori staff that set the tables up had no idea of how to do this by making sure that access to the kai and movement for all was achieved. Margaret believes 
I can tell when someone has been brought up around their marae when occasions like this occur and those who are Maaori with all the good intent try to help, but what resulted is that when casting my eye over the setting, I knew that people would not be able to get to the kai and eat comfortably. I changed the setting so people could do this, but on reflection I needed to be mindful not to assume that all Maaori know how to do this and hopefully $I$ haven't trampled on their mana. This wasn't my intention but I had to change the setting so people could eat without restriction

(Margaret, iv4, p.6)

On reflection, the occasion just mentioned may have been an ideal exercise whereby Maaori staff who were familiar with these kaupapa could have been encouraged to participate with those who had confidence in demonstrating this. I do believe the kaupapa of whanaungatanga and manaakitanga will be established and this will ensure the survival of these social behaviours by Maaori. To not encourage those lacking the knowledge, will only result in the same mistakes being made (unintentional) if Maaori staff do not consider this an important taki to be conducted and ensure the mana of people are left in tact.

For Kim the kaupapa of manaakitanga is a principle that, as an organisation, they should be practicing from because it is part of their statement around them as an organisation. For Kim, since undertaking doing this journey, it has been revealed to her how we measure as an organisation, if we are meeting the outcomes of this kaupapa. We are expressing this in words but are we actually doing this by our actions - and only the people we are caring for can tell us. At present Kim indicated that their organisation has nothing to gauge this by so it's something that needs to be addressed.

In our first conversation when Ani was reflecting on growing up as a child, she remarked about how as children they were taught the basics of what to do when visitors came to their marae

We contributed by helping with the setting of the tables, putting everything in the correct place under the watchful eye of a kuia. I loved this because it also allowed me to be with my cousin and when we finished off we would go to play

$($ Ani, ivl, p.4) 
But this allowed us to learn what to do when it came to demonstrating manaakitanga. Of course it never had a kaupapa attached but we knew what we knew and we did it automatically when we reached an age of being able to fulfil these obligations.

For Hineroa the kaupapa of manaakitanga comes in many forms but in her initial conversation she talks about the contribution her grandfather made to the hapuu.

My grandfather had green fingers, which produced large quantities of vegetables. He also provided meat for the many hui conducted at our marae

(Hineroa, iv1, p.3)

Hineroa's grandfather was renowned within his hapuu for the provision of the food needed to express manaakitanga to those who visited. He loved doing this and he provided the vegetables for the whole hapuu situated around their marae.

As a kaupapa manaakitanga brings many positive rewards. It enhances the contribution of showing hospitality to people and ensures that one's hapuu and iwi are remembered for their generosity towards those who visit their marae. It also ensures that whaanau members are taken care of in situations at times that would not be obvious. As an idea it would benefit those organisations that struggle to comprehend the value of this as a kaupapa but it brings with it results that are rewarding and inspiring. When put in place its value is such that people respond in a way that encourages reciprocation. All of which can only be a way forward that produces a wellness focus.

\section{Rangatiratanga as a means of maintaining successive generations}

Our rangatiratanga in this regard has been maintained by successive generations of marae committee participants and those who have supported their efforts through their monetary contributions and other personal efforts towards maintaining our identity as Ngaati Pareraukawa. I would not be out of place in my view, lining the walls of our dining room or perhaps a similar panel with a name like Naau te rourou, naaku te rourou (your food basket and my food basket).

(Nicholson, 2006) 
With these thoughts in mind the basis of rangatiratanga is around leadership but in many forms and as Iwi Nicholson has expressed - is achieved through the role modelling of those who ensure the affairs of one's marae are functioning at a level that benefits the whaanau, hapuu and iwi members of Ngaati Pareraukawa.

Diamond (2004) cites Roger Maaka whereby he points out, customary leadership roles, like the rangatira who had the ultimate say in just about every area of iwi life, no longer applies. Iwi affairs have become too intricate. This is largely, because of Te Tiriti o Waitangi claims process, which requires a complexity of skills at different times. Iwi and Maaori organisations are now multi-million dollar organisations, delivering services and managing assets. As life grows more difficult, no one person is likely to have the gifts, or the backing, to cover all the bases. This suggests that the old marae-based model - where whakapapa reigned - is no longer a viable option. Maaka argues this is the price we pay for modernisation, and we're likely to see more team-based leadership. The questions I then ask myself is 'as a kaupapa within this contemporary setting, how does rangatiratanga apply'? And, these participants reflect this in many ways.

When holding our third conversation Aroha brought a whole lot of koorero to the table and I do believe she was not aware of the kaupapa around rangatiratanga she reflected in her everyday practice. When relaying her experience around whaanau visiting their whaanau member being cared for, her role as a rangatira is to ensure that manakitanga is expressed appropriately by the example she models and through her actions and she was reflecting this, but without being aware that what she was doing as rangatiratanga merged into the kaupapa of manaakitanga

When discussing these various kaupapa I hadn't been able to get my head around how the roles are integrated. The penny has dropped and only since taking this journey have I really comprehended the integration of these kaupapa. In the area of rangatiratanga or leadership or being a leader as such it wasn't until I drew this diagram, considered our conversation, and then wove together the various threads, that I comprehended what was being reflected. All these kaupapa work together and at times in unison. This has been a sobering thought

(Aroha, iv3, p. 4) 
While in conversation with Te Ata regarding managers and their different styles she commented that in one situation she had seen four managers come through the one system she was employed in. In one incident she remembers a manager imposing her values and beliefs around an area that she didn't have any connection or jurisdiction. It got to a stage where Te Ata had to be firm with this person and point this out

Just because you are the manager here doesn't mean you can tell people on their marae how to do things. You don't have that right. What is it you don't understand? This manager had to sit and think for a time about what I had just said and the consequences of her actions if she tried to do this

(Te Ata, iv3, p. 5)

On reflection Te Ata felt that because this manager had the 'authority' to make decisions for her organisation she did not stop to think about her actions as far as demonstrating rangatiratanga to the marae and the people they were going to visit. She automatically assumed that what she was doing was being helpful to those people, when in fact she was having the opposite effect.

There are several ideas that have been expressed by Margaret relating to the kaupapa of rangatiratanga. It has already been identified concerning the staff crèche, - where was the rangatiratanga exhibited by the hospital board or the people who first mooted this subject and then proceeding to encourage staff to put their time and effort to achieving this, resulting in nothing occurring. This lack of leadership leaves people feeling discouraged and unable to trust the system that employs them and trust even less the rangatira of management.

It also reflected in Margaret's comments around the nursing organisation in which she played a predominant role as directing rangatiratanga. At times this proved difficult because of the issues that would arise on factors of 'being Maaori'

To do this work effectively one needed to feel appreciated in the role in which I found myself as a leader, while the current situation is being sorted. You can only succeed if the collective is behind this move but this was not the case in this organisation

(Margaret, iv2, p.4-5) 
When reflecting on these comments of Margaret's it took me down memory lane where I had a leading role in this particular professional nurses' organisation. I as the researcher can endorse these feelings, because even fifteen years later, the stance on recognising a Maaori worldview in this organisation is difficult to achieve because of the relatively small number of Maaori nurses. This then becomes the logic, which governs how much funding is available to those Maaori nurses for their particular section of the organisation. This is gauged on quantity rather than the development of a Maaori worldview, which then drives the kaupapa and not that of rangatiratanga to be expressed. It is a continuing problem within such organisations that are driven by a Western worldview. Where the kaupapa is that of money then it is not of a positive development for Maaori nurses. This will always be an ongoing saga for Maaori nurses in a professional organisation that conflicts with a Maaori worldview.

As Margaret remarked the poowhiri her present employment reflects this. We say we are a tikanga Maaori organisation yet our practice's particularly that of rangatiratanga, are not done according to this kaupapa. All of these kaupapa interlink, - if you don't demonstrate manaakitanga then rangatiratanga is not projected and so on. Which is correct and we cannot say one is more important than the other. But what is important is to be true to ourselves as being Maaori and this is to behave in a way that is mana enhancing to others.

In Hineroa's situation she explained that rangatiratanga had been demonstrated in her present place of employment. How they do this is when those Maaori who are new employees and a poowhiri is conducted, in the whaikoorero the speaker makes mention of the fact that as the rangatira of this space and place they are now coming to work in, they are welcome to be part of this space and place and to call it their own because this has now being given to them by those who are employed here.

With Kim, this as a kaupapa within her organisation is such that our people deserve the best care and this can only be demonstrated by the rangatiratanga we as staff and health professionals express. To not do this as an organisation then makes a mockery of this principle that we aspire to. We may not capture this fully but we need to ensure that we do strive to do this for our people. They are the ones that can tell us whether we are succeeding or not. 
Legislation and policy that embrace the health settings should reflect rangatiratanga but it hasn't and these consistent changes have seen little difference on our people.

Kim remembers an old kaumaatua saying, to demonstrate rangatiratanga, you know that rangiora tree and you know that they call it the bush toilet paper tree. If you look at the tree, the trunk and roots share Papatuuaanuku, it has a dark side of the leaves and there is the light side of the leaves. The leaves are different on both sides and we share the same trunk, roots and soil but if we are to ensure rangatiratanga then we need to work together. We all need to take note of what's in front of us that nature gives us as a taonga to reflect this, but we don't. Until we do, then we will be a nation not attuned with one another and all the kaupapa demonstrated will not be beneficial if both Maaori and Paakehaa don't understand this.

One aspect of rangatiratanga that I need to acknowledge regarding Ani is her unfailing and consistent loyalty as a kaiawhina within the confines of Te Waananga o Raukawa and the delivery within the hauora programmes in which she teaches. I love giving back to other students and it allows me to give something back to the waananga. It has been a two-way thing I believe and it is something I am happy to do. Ani's expression and contribution of her behaviour reflects rangatiratanga in way that she does so well as a role model, and as such, she has an impact on the students.

The usage of the kaupapa as a collective emerged through the whakapapa and life-stories of the participants and this has reinforced their present day reality on their nursing practices. The customary and the contemporary kaupapa are merged and brought through to the present. It is by taking this journey with the participants by entering their lived life experiences that the reader can begin to think about ways of doing, knowing and being as projected by these six Maaori registered nurses - that is they begin to understanding what being Maaori is for them. By thinking and reading about the journey taken by these six participants who reveal that the collection of kaupapa are the interlinking factors to their everyday practice this is when it can bring to mind, acceptance and understanding. Through these whakapapa and life-stories with the usage of the kaupapa, we can learn about the professional and personal changes, opportunities, chances and conflict these six participants took and were exposed to in their nursing practice. 


\section{Summary}

The life-stories disclosed by Kim, Ani, Te Ata, Hineroa, Margaret and Aroha capture 'being Maaori' is 'who and how I am'. What emerged was a 'collection' of kaupapa that showed how these six participants were embedded in their tikanga and kaupapa and this flowed into their nursing practice. Table 1, presents a summary of these kaupapa. The revelation of these kaupapa introduces the reader to the 'what' and 'how' associated with 'being Maaori'. Because of this, these participants and those Maaori whom they care for are open to shifts in thinking and changes around the care being provided.

Table 1: Kaupapa themes

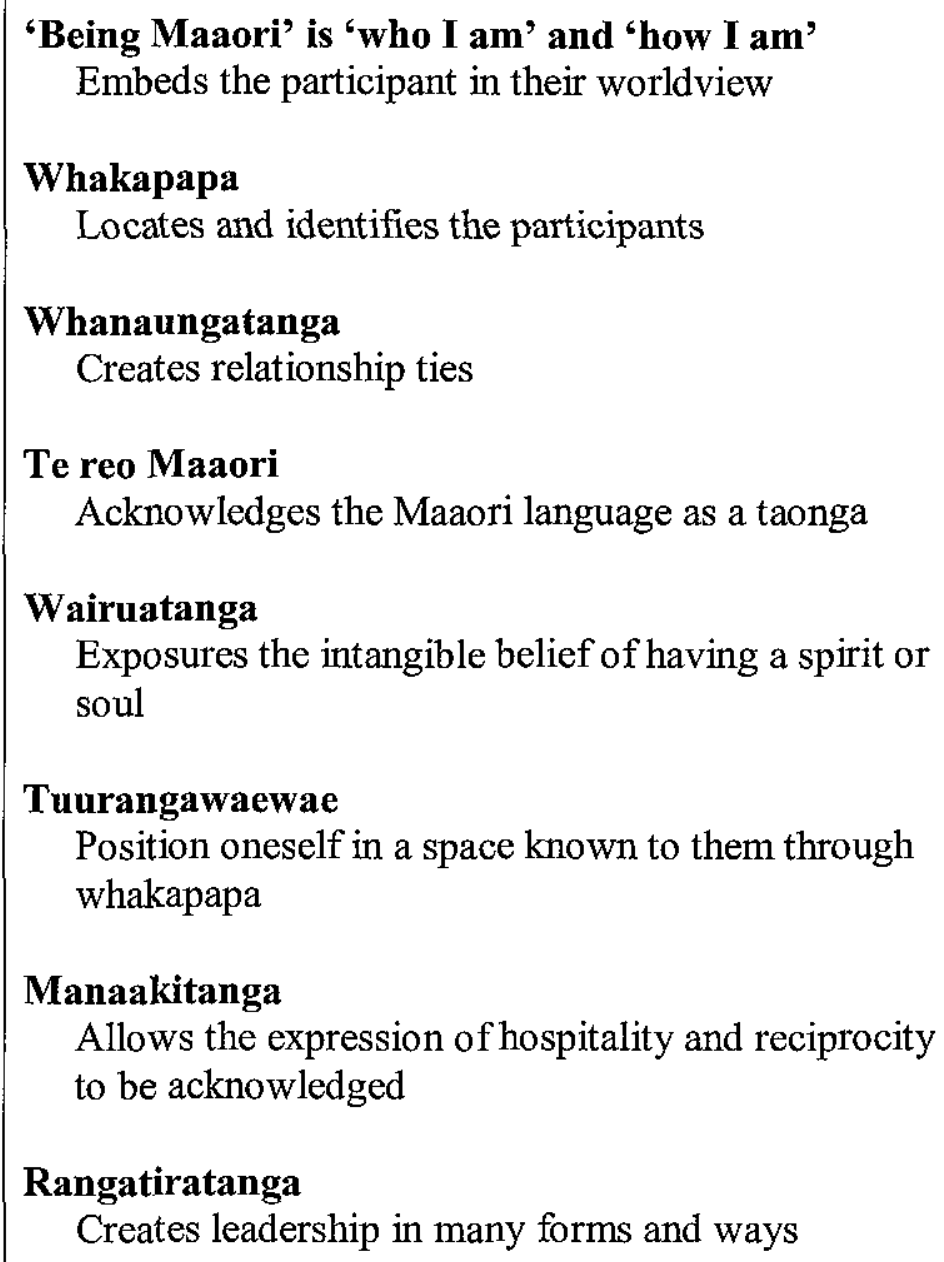

The kaupapa 'being Maaori' is 'who I am' and 'how I am' unite and merge ever so silently with whakapapa, whanaungatanga, te reo Maaori, wairuatanga, tuurangawaewae, manaakitanga and rangatiratanga. The importance of these kaupapa themes reveal the 
overall stance and beliefs of these six participants. They are interwoven and interlinked as integrated practices of what constitutes Maaori registered nurses' understandings of Maatauranga Maaori within nursing practice. And, how do they apply these understandings in nursing practice? As they know it.

Since our conversations, these participants have revealed that this research has given them insight and awareness of their practices as Maaori nurses. These participants had no preconceived ideas that what they knew and understood regarding Maatauranga Maaori and its implication within their practices, was deeply embedded in their day-to-day practice as nurses. The active participation in this research, encouraged them to reflect on their journey and what they do in their lives, which make them the Maaori nurses they are today. The understanding they have around the kaupapa disclosed, eventuated from their lifestories, which then allowed these threads to be unravelled and threaded to and fro across our conversations. Just as the warp and weft indicated by Russell Bishop in Chapter 3. The stories revealed in this chapter provide insight into the lives of these six participants and their reacceptance of challenges, taking a stance, creating opportunities, working with conflict and being who they are.

I have endeavoured to share the participants view on 'being Maaori' is 'who I am' and 'how I am'. These stories bring with them a 'collection' of thoughts, for example the kaupapa of manaakitanga is expressed in a way that reflects the hospitality needed to be conveyed to people who are visiting their whaanau members, but what was exposed is the lack of commitment by others (including Maaori health professionals) to demonstrate this in a way that reflect this kaupapa correctly. This as a statement should be alarming to hear but not an uncommon occurrence because of the compromising situation these health professionals, who identify as Maaori, find themselves in. Hence, the need to ensure that 'awareness' is created and introduced into nursing practice, which can be through the undertaking of research studies such as this. By constantly engaging in the 'what' and 'how' of living their lives as 'being Maaori' shapes the way in which these six participants expose themselves to the joys, disappointments, struggles, challenges, benefits and stances that go with this viewpoint.

To be able to practice in a way that recognises the kaupapa disclosed, all of these participants where unyielding in their tikanga and kaupapa of 'being Maaori' and one thing 
stood out -- you must be embedded in knowing who you are, which then reflects what you do. Another was the introduction of te reo Maaori as a medium of communication while caring for Maaori. This as a kaupapa has been an ongoing issue and the constant reminder to people of influence that it has value and importance within health settings and needs to be pushed and endured by those who can effect change in a positive manner. These participants have been tested at times but they continue to nurse despite the challenges and struggles they have been exposed to. They cannot ignore this because for them 'being Maaori' is 'who I am' and 'how I am'.

How do these six participants practice? They demonstrate this by 'being Maaori' by their identity, claiming, locating and positioning themselves in such a way that allows their trustworthiness, integrity, honesty and openness to be exposed in the settings they practice in. To achieve these goals of openness and authenticity, these participants 'step up' and 'cross the line'. As a group they portray this in many ways and means but still maintain what and how it is to be Maaori. This means challenging the norm and putting themselves in situation which have the potential to be uncertain and risky. In their beginnings, from conception, althrough childhood, adolescent, adult, nursing student or nurse, each participant has been exposed to and experienced times when they have 'crossed' that line. They at times have had to come to terms with being married to someone not of their worldview, producing children of mix marriages, bringing with it mixed beliefs and values. It has occurred that they bring to their nursing practice, mixed tikanga and kaupapa, which for some has tested them, but for those strong in their worldview it has not deterred them from practising in a way that reflects 'being Maaori'. It is hard 'being Maaori' all the time and to resist conforming, because to be this way, constantly, 'wears' away at a person and their wairua may become unbalanced, which then impacts on their mauri and mana. One should never have to face this but these participants have, especially when the dominant worldview is not reflective of their tikanga and kaupapa within their nursing practice. To be seen as standing firm or challenging, means helping our people in a way that demonstrates what it is we know from a Maaori worldview, and that is 'care' should be conducted from this stance. If it means making a difference for our people these participants will continue to practice in a way that reflects 'being Maaori' is 'who I am' and 'how I am' and nothing can change this. 
In the previous chapter, I introduced the whakapapa stories of the six participants by using the backdrop of whakapapa as imagery and then focusing on 'being Maaori'. In this chapter, I have continued the use of whakapapa as a backdrop but inverted the situation to reveal the interwoven thread or kaupapa - of 'who I am' and 'how I am'. From this a collection of kaupapa has emerged and is interlinked with the nursing practice these participants are engaged in. The lives of these dedicated and passionate women are forever evolving; forever changing with each successive generation and so will these kaupapa. It is who they are as 'being Maaori'.

In the next and closing chapter, I present my concluding summary on the research, the research positioning, key kaupapa findings by reflecting on these conversations, including some conjecture regarding the research, and thoughts or ideas for further research into 'being Maaori' and to do this has been 'who I am' and 'how I am'. 


\section{Chapter 6 Concluding summary}

While the values and beliefs of care for Maaori are perceived as being consistent with a Maaori worldview, the outcomes that have been created by those of a Western worldview, have fallen short of this expectation. This thesis explores the appropriate technique from which key kaupapa inherent in Maatauranga Maaori enhances and embeds the way in which care should be maintained by and for Maaori. The what and how research questions and the introduction of the whakapapa and life stories of the six participants has been the way in which this has been accomplished and, it has been an uplifting and rewarding experience. The exposure and awareness about research and writing gave me the motivation to continue on this pathway, but, in particular, this study has given me the opportunity to conclude this summary in a way that will bring some meaning. I know and hope that other Maaori registered nurses will take the opportunity to further their study of 'being Maaori' inclusive of the reaffirming and re-engaging with 'being Maaori' is 'who I am' and 'how I am'. This research has allowed me to reflect and take the opportunity to understand what this means. Without this study I would not have been able to contribute to these ideas and thoughts. More importantly the manaakitanga and whanaungatanga demonstrated by my whaanau, hapuu and $i w i$ have been a pivotal contribution to this study. Without them I would not be who or where I am today. I therefore consider that my kaupapa involved in such research, allows the locating, positioning and claiming of this from a Maaori worldview. It is as Jacq Carter states 'being Maaori' for me is 'knowing I am Maaori as being opposed to being told I am Maaori'. It taught me that there are many ways to express this.

\section{The positioning of the research}

From the outset Maatauranga Maaori was the epistemological framework that this research would be positioned in. It allows Maaori to claim, locate and be situated in a space and place that is of their making. The attempt by Paakehaa to state to Maaori the way our health and wellbeing should be maintained does not enter into this framework. It is as Whatarangi Winiata states with all the good intent in the world, Paakehaa have tried to tell us how to live in the world, without success. 
The worldview from which this research is positioned is that of a Maatauranga Maaori continuum. The tikanga and kaupapa associated with this viewpoint 'signpost' the direction that should be taken. It is a knowledge base that is taught within those customary Whare Waananga, allowing those of this contemporary period to embrace and embed oneself in these concepts. It is our obligation as contemporary Maaori to do this. Our tuupuna willingly or unwillingly embraced values and beliefs not of their worldview, to ensure the physical nature of their lives was maintained. To do otherwise, would have been the demise of Maaori. For Maaori in this twenty-first century our tuupuna left a legacy in the form of marae with their whakairo, tukutuku, whaariki and the whenua they positioned these buildings on, as the bastion point for us to be who we are as Maaori. It allows our language of te reo Maaori to be spoken and the kawa in which we are embedded to be displayed, for all to see, without having to think that the values and beliefs associated with a Western perspective.

Chapter 3 opens the gateway to the reason why this study is positioned from a Maatauranga Maaori continuum. The intent of this thesis and these research questions is to explore Maaori registered nurses' understandings of Maatauranga Maaori within nursing practice and how they apply these understandings in nursing practice. The question then is, what is it that Maaori nurses do to make them who they are and how they are. I choose the means of whakapapa and life-stories - oral stories as the method to uncover the lives of these Maaori nurses who practice from the worldview of being Maaori. I then, through the kaupapa of whakapapa and whanaungatanga, recruited six participants to take part in the study. By doing this, I wanted to disclose through conversations why these participants had a passionate desire to practice in a way that reflected 'being Maaori' is 'who I am' which then interlinks and weaves into the kaupapa of 'who I am' and 'how I am'. Before we engaged in conversation, I had to ask myself 'are these participants aware of what they do in their everyday practice'? I had to do this because I was questioning myself in this regard.

What eventuated was that in the end, while the participants volunteered their time and openly wanted to be known by their given names and not by pseudonyms, their belief in being Maaori was 'silent' but deeply positioned in their day-to-day practice. Because of this, they did not consciously think about it. It was a natural progression for them. In taking this journey voluntarily and without pseudonyms, the recognition and desire to put it 
out there as 'being Maaori', made them, I believe, more determined to share, explore and reflect this stance. As we shared this pathway together, their disclosures clearly made an impact on them. This strengthened the whanaungatanga ties we already had with each other and ensured that manaakitanga and wairuatanga were forever present when we met and in my writing. It is these kaupapa that make the participants the nurses they are and makes me the researcher I am today.

The view that oral stories is a questionable way of gathering literature for research has been part of the positioning and development. Because oral commentaries are holistic in nature this would not be a stance that those from a scientific viewpoint would endorse. Freyerabend questions whether the objective viewpoint of science is validitated and Campbell contends that scientists may not be objective in their decisions. The contribution of Maaori and Indigenous educators and researchers' writings support the application of oral stories as being part of research methodologies.

The introduction of Te Tiriti $o$ Waitangi has not had the profound effect as believed. Constant changes to legislation and policies by Governments has led to negative outcomes for Maaori. Even with these obstacles we need to ensure as Maaori registered nurses, that we endeavour to provide care to Maaori so that their health and wellbeing will be maintained and positioned from a Maaori worldview. Kawa Whakaruruhau/Cultural Safety became a way forward for Maaori nurses to have a voice and this allowed the application and understanding of what care for Maaori meant. Kawa Whakaruruhau is inherent in Maatauranga Maaori.

Many challenges were part of this research and in Chapter 1 , I outlined some of these. To divulge, position and tease apart the threads of the lives of these Maaori registered nurses, one needs to respect and acknowledge their conversations, as making a contribution to the theory about Maatauranga Maaori and its influence in nursing practice. To ensure this occurred, the introduction of Maatauranga Maaori as a framework, allowed the voices of these six participants to be central. To achieve all this, it had to reflect a Maaori worldview. These Maaori registered nurses whakapapa and life-stories their interpretation and understanding of their experiences have never been recorded. By remaining unvoiced their positioning in nursing practice meant that no literature was available in nursing education or in the wider public, in these important issues. I concur with the statement 
made by Linda Smith, that to make sure our struggles as Maaori women are recorded, we need to take up the challenge and voice this. I consider this study makes an important contribution to the awareness of Maaori peoples (and those not Maaori) on the use of Maatauranga Maaori as the epistemological framework, where life-story - oral stories as a methodology and method in qualitative nursing research can show the way forward. It then makes a contribution to the literature on what and how Maaori registered nurses view the influence of Maatauranga Maaori within nursing practice.

Another area that tested my ability was in the analysing and interpreting stage of these participants' voices and how I would represent and position this. I continually asked myself who chooses the stories to present in Chapter 4 and 5? Because as I indicated in Chapter 1, my 'voice matters just as the participants voices mattered'. So would my voice be seen as superseding that of the participants, which is not the purpose of this study. As I identified in Chapter 3, the many interpretations of rigour created confusion and, I believe it is the same dilemma with whose voice should be dominant. It stands to reason that the voices of the participants are paramount, without them there would be no stories. I believe, I can only interpret them from my own holistic and authentic position as 'being Maaori', arising from my experiences as a Maaori nurse that may be similar to theirs or it may not. By using the tikanga and kaupapa of whanaungatanga, the participants and I acknowledged a shared voice in conversation, and I consider this a strong point of the study, as evident from the depth and wealth of knowledge on the what and how Maatauranga Maaori as a kaupapa influenced their practice. Another strong point of this study is the desire and passion of the participants to be known by their given names and not pseudonyms. In doing this I believe they are making a statement that says, its time the wider public audience heard our stories on the what and how our Maaori worldview should reflect in the way we care for people in our everyday nursing practice.

The issue around revealing their stories under their given names was more of a concern for some in the $\mathrm{PhD}$ school rather than the participants. The concerns about what and how this was to be disclosed and positioned became the question. This was to be handled in a way that ensured there were no unpleasant implications or revelations about people. These are the whakapapa and life-stories of Kim, Ani, Te Ata, Hineroa, Margaret and Aroha who disclose 'being Maaori', which then merges with 'who I am' and 'how I am'. They have 
disclosed what they want to be known, which allows the reader to reflect and consider what these Maaori nurses do in everyday practice when they care for people.

These participants' whakapapa and life-stories disclose and position what they know about themselves, their whaanau, hapuu and iwi. Through the kaupapa of whakapapa, whanaungatanga, te reo Maaori, wairuatanga, tuurangawaewae, manaakitanga and rangatiratanga, is established a relationship that ensures it is reciprocal and acknowledges that we are intertwined and woven together through our links. This allows the conversations to flow, with the feedback on the whakapapa and life-stories and kaupapa themes becoming evident. It allows who we are as Maaori to be evident when conducted from a worldview that reflects this. Storytelling and storytellers are what we do as Maaori women and have done through the centuries and this is the main reason I selected lifestories - oral stories as a framework, methodology and method. It is what we do in nursing practice as the means of communication to other nurses when conveying the care we have provided to people when feeding back at report time. I did not want to work with a text that did not reflect this type of practice because it is about the participant's lives, lived over time, inclusive of the collective and by maintaining the kaupapa this was encouraged to happen.

Being part of research that is positioned and located differently to one's worldview is a challenge, both personally and theoretically. I needed to be mindful of the requirements of $\mathrm{PhD}$ work when constructing this research. This involved challenges and what my interpretation of what these were, I believe has been explored by the whole construction of this research. The conversations produced, generated overwhelming amounts of information. Through the work conducted by Rose McEldowney, which is described in Chapter 3, I was able to utilise and acknowledge her analysis and interpretative formula for using life-story - oral stories as methodology and method, and to construct it from a concept belonging to Maaori, in order to develop the text. This was identified through the use of whakapapa as imagery for their stories and the kaupapa themes to emerge. I had no desire to put a theoretical slant on these participants conversations because we are attuned to 'being Maaori' where our stories speak for themselves and by the many oral and now written composites produced over the centuries by our people. Why then would I want to change something that has worked for us. It also diminishes the wairuatanga that is interwoven into these participants' stories and this must never be lost because it is who 
these participants are and who I am as the researcher. One aspect that needs considering is that there is a large amount of data that has not been used and there are further stories that need to be produced at some stage in my journey.

What these participants and their stories have revealed, which has never been discussed with their whaanau let along the wider public, shows there is a need for Maaori nurses to write and position how we view the world and why we do the things the way that we do, in our everyday nursing practice. I am aware that the interpretation of the texts is influenced by my own whakapapa and life-stories and personal experiences as a Maaori nurse, who embeds herself in Maatauranga Maaori as a way of life. I am also aware that my interpretation of the text is influenced by the minimal amount of literature both oral and written by Maaori on subject matter that includes education and other areas, but with only a slim amount on nursing. My theorising around the kaupapa themes has a connection with what is known and discussed in the oral and written literature, what the participants have disclosed with me over time, and, how my intuition, feelings, desires, passions and views reflect Maatauranga Maaori as way forward for nursing practice. The participants themselves brought with their whakapapa and life-stories, their intuition, feelings, desires, passions and views on the what and how Maatauranga Maaori influences their nursing practice. These whakapapa and life-stories will be made available for readers to gauge and gain insight - so that one can connect with the experiences and thoughts of the participants and consider one's own reactions and reflections of the texts.

I have included the participants' whakapapa and life-stories so that the reader can gain a sense of who they are, and how and why they do the things they do as Maaori nurses in their everyday nursing practice. These participants are not setting themselves up as exemplars of Maaori nurses; they want people to learn from their experiences. This is how they have lived and positioned their lives over a time and nothing can change this. They have adapted to the changes in their lives and endeavoured to interweave this into their everyday existences, which at times has proved difficult. They are human beings just like other human beings who make mistakes and do things that are not recognised by those who are not of their worldview, as being normal behaviour or practices. They have become discouraged and angry at times but is not this a normal human reaction when faced with situations like this? As Maaori nurses they are aware and recognise this as being part of who they are and what and how they do things as 'being Maaori' and this is, the part of 
their authentic selves they integrate into these kaupapa in their everyday lives. This allows them to reflect on ways to incorporate or demonstrate what 'being Maaori' is and then reflect this in their nursing practice without constraints. In fact they would be more than disapproving of themselves if these were not the type of practices they practised with people, whether Maaori or Paakehaa, because it would contravene the tikanga and kaupapa in which they have been embedded and have disclosed.

These whakapapa and life-stories have arisen from their own experiences working in a predominately different worldview not of their making. Even though some have mixed marriages and produced children from this union, they stay true to themselves and encourage and guide their children and spouses to understand this worldview they have lived over time. These participants have never paraded their differences with public disclosures, until this study. But what has occurred is that their experiences have positioned them as Maaori women and shifted their thoughts, ideas, desires and passion to make a difference in their own lives and others' lives, so people will know and understand. These participants are not Maaori women who saunter or parade in such way that could be misconstrued and misinterpreted, because for me they are gentle, caring, loving and humble Maaori women who are saying enough is enough and it is time our stories were told.

While reading Rose McEldowney's work, the story map she created became the key to unlocking my thoughts on constructing the whakapapa backdrop. The usage of whakapapa as a backdrop imagery allowed the participants to reconnect, link and reflect on their previous conversations so as to allow the flow and momentum to be sustained. I believe the whakapapa backdrop became a vital means by which the participants positioned their accounts of their life-stories, which in a way invoked and provided a way, as a framework to conduct and explore further ideas and thoughts.

The aspect of recording their whakapapa and life-stories or positioning themselves in a point in time was a natural progression to make. It is about the collective for these six participants and the fact is that as Maaori we are attuned to including those tuupuna from the past, which are then brought forward to the present. It is who we are and what we do as 'being Maaori'. Hence, it did not pose a problem for me in this research study. The participants talked in detail about the past, which is the beauty of whakapapa and its interlinking connections to whanaungatanga. As a kaupapa it allows this to happen so 
these participants will share what they want to and what they recall and remember. Whakapapa and life-stories are holistic, which includes one's whaanau, hapuu and iwi and for us as Maaori as being complete. By acknowledging that we are descendents of 'taonga tuku iho' allows us to say we are complete as a person because this includes those who have passed, to those now here and then on to succeeding generations. There is no one correct reading or interpretation of the stories that arose from this study. What has occurred is the unfolding and emerging of ideas about what and how Maaori nurses view Maatauranga Maaori as influencing their nursing practice. These ideas are not generalised to other Maaori nurses who practice in nursing. These participants are aware they will be challenged and they welcome this challenge just as I do as the researcher. However, I did find there was consistency and congruence within, around, alongside and between the participants' whakapapa and life-stories over time.

Because I have asked the participants to carry and hold over stories at the same time as telling stories that are of the past, present and yet to be, they have captured this moment in time. The construct of the stories have already been laid down in time by the whakapapa, whanaungatanga, tikanga and kaupapa that manifest itself in 'being Maaori' and how they are called upon to do this depends on the positioning of these ideas. These stories offer a pathway for others to follow and to offer inspiration, passion and desire that we intuitively know as 'being Maaori'. The whakapapa imagery as a backdrop, proved the most beneficial tool as a way of citing stories. The use of the tuakana/teina concept allowed the concept of whanaungatanga to be positioned and maintained.

In my ethics application I had to consider implications of tikanga and kaupapa that may emerge. This included being mindful of the whaanau, hapuu and iwi, which, as the collective, are part of the positioning of this research study. By putting their whakapapa and life-stories out in the public arena and by identifying themselves through their given names, all needed to be considered because this is what occurs when using life-story - oral stories. This is one of the ethical considerations when working with life-stories because the researcher is asking the participants to recall stories that have been significant in the what and how Maatauranga Maaori influences their nursing practice. What makes us aware of this?. It is through these participants who have lived and, for all, born into the world of storytelling, so those moments that we come to terms with of who we are and what we do as 'being Maaori', are what drives us to make differences and changes in settings 
and circumstances that affect our nursing practice. To expose one's personal traumas or experiences of having violence as part of your life, would cause pain and it is for the participant to ponder and reflect on whether to disclose this or keep this hidden. There was no need to check or recheck if this was a problem because from the outset this was recognised and became an acceptable way of acknowledging things that may be considered unpleasant. This is what the kaupapa of whanaungatanga, manaakitanga and wairuatanga allows to happen.

Using this type of methodology and method of whakapapa and life-stories was a timeconsuming process for the participants. I wondered if all could cope because of the time we would be spending together despite their own personal and professional commitments. But it was the only way in which to unfold the depth and wealth of the day-to-day existence and experience of these Maaori nurses who are engaged in practicing from a Maaori worldview. Because the fact that 'being Maaori' as who these participants are and who I am, allowed the kaupapa of whanaungatanga to come to the fore this smoothed the pathway of the amount of time needed to be spent with the participants. It also determined the where, when and how often we met. They all stayed to the end of the study and as participants indicated that they found this a rewarding experience and it made them think about their practice. Aroha stated that this journey has made her reconsider what it is she wants to do in her life in particular to forge those links with her hapuu, Ngaati Huia. This may be a journey she needs to take to revitalise this aspect about her hapuu. Hineroa commented that what this research was achieving was a pathway for other Maaori nurses to be able to commence writing from their worldview without the constraints that comes with expressing this. Kim commented that using whakapapa imagery as a backdrop to show her journey as being a nurse, challenged her but also revealed aspects that she had forgotten but had still played an important part in changes for Maaori. It allowed her to reflect and ask the question that 'if we say we practice from various kaupapa, how then do we know we are actually reaching the outcomes if we do what we are saying we are doing'. Do we see or know we are producing the results these kaupapa reflect? Ani valued the experience and hoped that others will learn from this. In taking this journey Margaret said 'I am humbled' that my life-story would even be worth writing about but I am happy that I have done this and my journey is only just beginning. Te Ata expressed her appreciation of being given the opportunity to tell her story. 


\section{Key kaupapa findings}

What emerged as key kaupapa findings from this thesis is to show the contribution of Maatauranga Maaori towards the development and survival of Maaori and Indigenous knowledge. First, the emergence of Maatauranga Maaori as an epistemological framework in which to position one's research has become a way forward for Maaori nurses to consider. It allows for the consideration of people such as Russell Bishop who framed his research by the use of whanaungatanga but then had to align this with Kaupapa Maaori to justify its credibility to be used in his study. Recognising and acknowledging Maatauranga Maaori as an epistemological framework will allow all those kaupapa mentioned in Chapter 2 and 5 to be an acceptable way of framing their research study. Inherent within Maatauranga Maaori is Kaupapa Maaori. This then positions and locates kaupapa that is relevant to research being undertaken and to justify its credibility and trustworthiness, which we have as Maaori through taonga tuku iho. This framework allows and provides for the development of an educational curriculum and nursing practice that enhances nursing's ability to meet the needs of Maaori.

Another key finding is the use of whakapapa and life-stories that emerged from the application of Maatauranga Maaori as a framework. Ensuring that everything connected to this research is reflected from a Maaori worldview, allowed for the revelation of these stories. These participants were confident and comfortable as this research was conducted for, by and with Maaori. This included having a transcriber who was Maaori and who could follow when the participants dialogued in te reo Maaori - and was able to articulate their conversation. This encouraged them to focus on 'being Maaori' without reservation and feel they would be misrepresented. The kaupapa of whanaungatanga is paramount in this area because those relationship ties became a requirement in selecting the participants as well as that of whakapapa. It is a kaupapa that ensures the researcher honours their obligation towards the participant, their whaanau, hapuu and iwi when constructing one's research proposal and when writing the stories in relationship to the participants, because it is all part and parcel of 'being Maaori'.

From these whakapapa and life-stories this reaffirmed for me a collective of key kaupapa findings that are part of the driving force behind the everyday practices of these six participants. These being whakapapa, whanaungatanga, te reo Maaori, tuurangawaewae, 
wairuatanga, manaakitanga and rangatiratanga. As kaupapa they reinforce and reflect the way in which these Maaori registered nurses unconsciously go about their day-to-day nursing practice by the contribution of these kaupapa. It is the glue I believe that holds together what 'being Maaori' is for these six participants allowing them to demonstrate these kaupapa without restriction attached but being mindful that the predominant worldview they practice from is a Western viewpoint. They are aware of this and challenge this stance when the occasion occurs, enabling Maaori to be cared for in a way that reflects 'being Maaori' is 'who I am' and 'how I am'.

\section{Propositions resulting from the research}

What then can be said has been gained from this thesis and the research questions posed namely, what are Maaori registered nurses' understandings of Maatauranga Maaori within nursing practice? And, how do they apply these understandings in nursing practice? The first proposition is that there needs to be a movement towards life-stories - oral stories as research on the life experiences of Maaori nurses in order to understand what they do, and how they do it, and why they do what they do. No other Maaori nurse has attempted a study of this type. There was no evidence in the literature that addressed the life-story oral stories experiences of 'being Maaori', which lent itself to 'who I am' and 'how I am'. This allowed the emergence of a collection of kaupapa to be established, namely whakapapa, whanaungatanga, te reo Maaori, wairuatanga, tuurangawaewae, manaakitanga and rangatiratanga. It is important that the embedding, locating, positioning and claiming that arises from the everyday practices of Maaori nurses through theses kaupapa, is recognised and acknowledged as being able to inform nursing practices.

Second, to give rise to an epistemological framework, namely Maatauranga Maaori is saying that research studies undertaken by Maaori can be positioned from this viewpoint. The many concepts associated with this stance are to ensure the health and wellbeing of Maaori is gained and maintained. There is a need for more research frameworks to be developed by Maaori, which reflect their worldview. We must not shy away from such pathways because if we do, our survival as Maaori will not be successful.

Third, the pathway to include oral commentaries as a way in which to position one's research is one that needs to be continually challenged. Science and those scientists 
associated with this worldview who are predominately Western, consider objectivity is the means to determine answers to how one views the world, which is in complete contradiction to that of Maaori and Indigenous peoples. As outlined in Chapters 1 and 3 oral means are about the holistic nature we as Maaori are attuned too and interwoven are the concepts of wairuatanga and whanaungatanga. This determines how we maintain the health and wellbeing of our people. There is a need for more Maaori academics and researchers to question and debate the views held on the credibility of oral means as a way to construct one's research study. We need to challenge this Western viewpoint to ensure that what our tuupuna believed was the way to ensure that 'taonga tuku iho' and what it represented for us becomes the means by which we validate oral stories being included in our research studies.

Fourth, this study has focused on Maaori nurses who acknowledge that 'being Maaori' is part of who and how they are. Because the focus is from a Maaori worldview, I do believe as the researcher, it becomes a subject that is not discussed by both Maaori and Paakehaa nurses (for some not all nurses). This is due to the fact that when a person is not of a worldview reflective of their values and beliefs why would they embrace this understanding. There are those who hesitantly identify as Maaori, purely because of their limited understanding around what 'being Maaori' for them is based on, besides a minimal amount of understanding around the concepts that has been disclosed. There are those Paakehaa nurses who avoid the subject because they simply do not identify as 'being Maaori', so as a notion, is of no importance to them. If those nurses both Maaori and Paakehaa have difficulty in expressing the tikanga and kaupapa that embeds 'being Maaori' then I suggest that we open the door to the possibility of other Maaori nurses telling their stories to gauge how and if they see themselves as practicing from a worldview that is Maaori.

Fifth, is 'being Maaori' and the kaupapa that is involved more conducive to having this conducted in a Whare Waananga that identifies as a 'tikanga' Maaori organisation than it is to be in one that has as its principles and beliefs not of a Maaori worldview? I ask this because if 'being Maaori' is 'who I am' and 'how I am' then how can this be achieved if conducted from the confines of an organisation whose tikanga doesn't recognise this. I believe it lends itself to further research into the what, how, why and where questions in 
relationship to the educational institutes who would provide the best insight and knowledge into 'being Maaori' is 'who I am' is 'how I am'.

Sixth, how do we support these Maaori nurses who view things from, and believe in a worldview that is not of the dominant tikanga and kaupapa as Maaori. These nurses have been 'silent' in their thoughts and ideas, so we need to find a way to ensure they are heard and it is through research studies such as these that this can be achieved. This needs to be encouraged and nurtured so other Maaori nurses may continue to research in this area of interest.

Seventh, what are some of the implications of undertaking Maatauranga Maaori as one's conceptual/theoretical framework approach. In the first section of Chapter 6 on the positioning of the research, I mentioned that this is a time consuming exercise and as such would it be considered for research funding? Literature written indicates research that is holistic in nature with an in-depth data collection has been given minimal research funding. However, in today's society funding is given to those of a shorter output framework, which consist of an objective outcome, has been the main area of concentration. To continue to maintain the health and wellbeing of Maaori, research undertaken from a Maatauranga Maaori continuum, should be funded so that a positive outcome can be achieved for Maaori. By the disclosure of these kaupapa inherent in Maatauranga Maaori will ensure the health and wellbeing of Maaori is maintained. We need to encourage and support more research from this framework by Maaori registered nurses. Another fact that influences research funding is that data written indicate that the 'disease' and 'illness' model is the way in which to ensure the health and wellbeing of Maaori is maintained. I contend that this research indicates that a 'wellness' and 'healing' focus is the way in which to proceed. This being the case, research funding should be allocated so further studies can be conducted from this viewpoint.

Finally, it is obvious from these six participants 'being Maaori' is 'who I am' and 'how I am' and with this thought in mind, the question I then ask, 'is the organisational structure they are employed in, congruent to 'who I am' and 'how I am' or is the opposite portrayed'. When in conversation with the participants there is the constant struggle to find organisations (including those who say they practice from a Kaupapa Maaori perspective) that actually have this infrastructure, knowledge and people with the ability to demonstrate 
this type of practice. We have the desire and passion but do we have the ability and understanding to do this? This is a question that needs to be researched to find answers that ensure that those who access these health settings are guaranteed that the tikanga and kaupapa these organisations aspire to are being attained.

\section{Concluding comments}

As I reflect on this journey, to undertake a research study of this magnitude through the use of Maatauranga Maaori through whakapapa and life-stories as a way in which to frame this work, has been a time consuming research approach. It took a lot of passion and dedication by the six participants, their whaanau, hapuu and $i w i$ to stay focused. It also involves the time and dedication of the researcher and their whaanau, hapuu and iwi. If Maaori nurse researchers want to voice and unravel their participants lived experiences of Maaori registered nurses' understandings of Maatauranga Maaori within nursing practice and, how do they apply these understandings in nursing practice? They then must be aware that one must spend time to find out the answers to these questions about who, what and how their lives have contributed to their passion of wanting to express themselves in this way to effect change. We as Maaori researchers have used the holistic metaphor of weaving to bring together the warp and the weft, construct a new form, decipher problems and identify the logic of the world, through language understood by Maaori and their worldview. The openness and honesty of Kim, Ani, Te Ata, Hineroa, Margaret and Aroha to tell their whakapapa and life-stories over a period of twelve months and the richness of the material that they gifted to me as taonga has been immeasurable. Many feelings come to the fore in these instances and there is simply not one feeling to express how I feel. 'Being Maaori' is 'who I am' and 'how I am' and I will express this with a collection of emotions. These being humbled, privileged, indebted, respectful and mindful that as participants you have given me this taonga (which includes my whaanau, hapuu and iwi) and I would like to take this opportunity to acknowledge your lives as lived over time as 'being Maaori' inclusive of your whaanau, hapuu and $i w i$.

I hope this research will be of benefit to those Maaori nurses who would like to engage in life-stories - oral stories as an approach and to take the opportunity to explore the day-today practices of Maaori nurses. The importance of Maatauranga Maaori as an epistemological framework is a key to unlocking 'being Maaori' and requires ongoing 
development. These are practices that will go unnoticed and unrecognised by the publishing world if we do not continue to research in this manner. By recognising the implications of 'being Maaori', we can then ensure that the tikanga and kaupapa that is embedded in our worldview is disclosed. Then and only then will it bring about an open honest change.

I would like to leave this study with the thought portrayed by Iwi Nicholson "Naau te rourou, naaku te rourou"; we can contribute to the survival of Maaori as a people and bring together those kaupapa that embed us as 'being Maaori' (Figure 9). It has been the final thread that links and completes the whakapapa panel I had in mind to design and weave while undertaking this research study. Still more can be added but that is the beauty about viewing the world through Maaori eyes. It brings with it the diversity, which allows us to capture and claim what and how we do the things that we do as being Maaori.

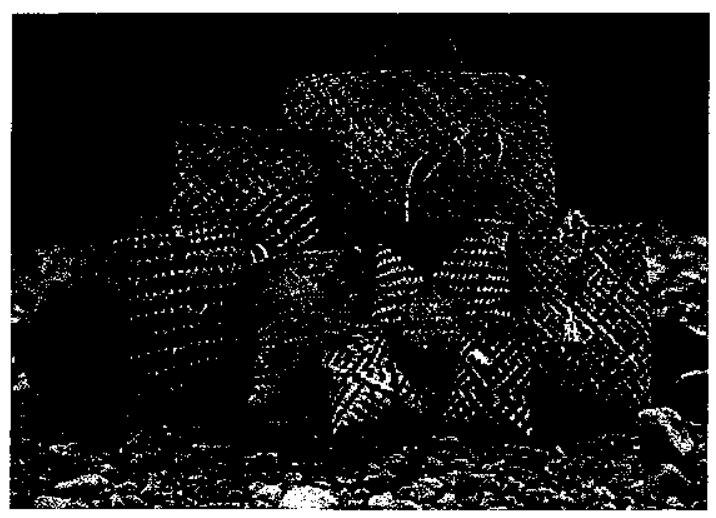

Figure 9: Whakataukii (Photography belonging to Hinepuororangi Winiata ${ }^{75}$ )

\footnotetext{
${ }^{75}$ Permission has been given by Hinepuororangi Winiata to use this photography within this research study.
} 


\section{Appendices}

Appendix 1

Copyright note on artwork belonging to Chanel Raewyn Taiaroa

Appendix 2

Iwi location map

Appendix 3

Memorandum from Convenor VUW HEC, 2 August, 2005 re:

ethical approval to undertake $\mathrm{PhD}$ research project 
Appendix 1 A copyright note on artwork belonging to Chanel Raewyn Taiaroa

All of the artwork depicted in this research study is the property of the above artist and as such cannot be reproduced or copied in any way or form. This work has been gifted as a taonga for the use in this project only. 


\section{Tribal Location Map}

Traditional tribal areas and locations resulting from nineteenth century tribal migrations (based on Appendices to the Journal of the House of Representatives, 1870).
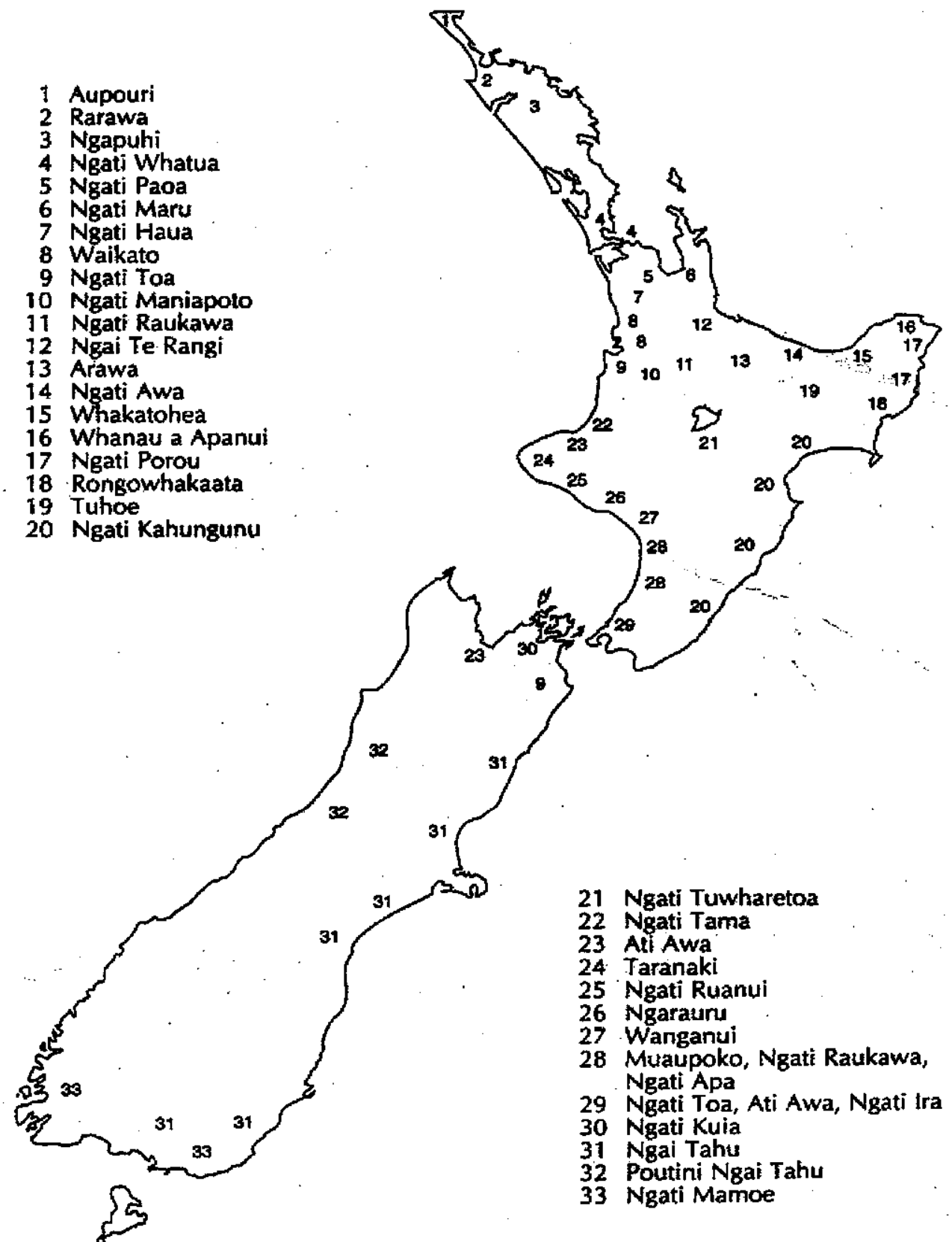
Appendix 3 Memorandum from Convenor VUW HEC, 2 August, 2005: re: ethical approval to undertake $\mathrm{PhD}$ research project

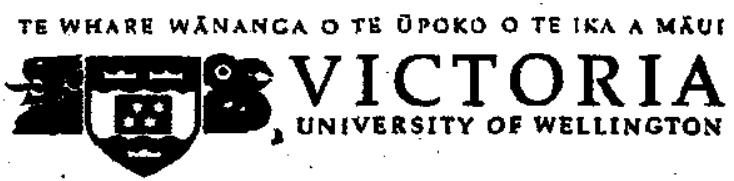

MEMORANDUM

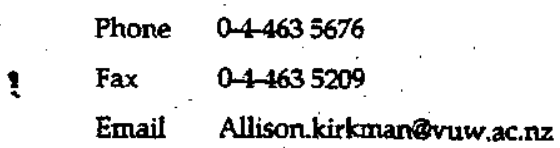

\begin{tabular}{l|l}
\hline TO & Helen Taiaroa \\
\hline COPY TO & Dr Rose McEldowney \\
\hline FROM & Dr Allison Kirkman, Convener, Human Ethics Committee \\
\hline
\end{tabular}

\begin{tabular}{l|l}
\hline DATE & August 2,2005 \\
\hline PAGES & 1 \\
\hline
\end{tabular}

SUBJECT Ethics Approval: No 72/2005 - Weaving the contemporary position of Matauranga Marori within nursing practice

Thank you for your application for ethical approval, which has now been considered by the Standing Committee of the Human Ethics Committee.

Your application has been approved and this approval continues until 30 December. 2006. If your data collection is not completed by this date you should apply to the Human Ethics Committee for an extension to this approval.

Best wishes with the research.

Allison Kirkman

Convener 


\section{References}

Acoose, J. (2001). (Ad)dressing our words: Aboriginal perspectives on Aboriginal literatures. In A. Ruffo (Ed.), A vanishing Indian? Or Acoose: Woman standing above ground? Canada: Theytus Books Ltd.

Adamson, M. (1998). Action research: The journey from enrolled to registered and beyond, discovering a process to promote self-efficiency and professional development. Unpublished Master of Arts in Nursing thesis, Victoria University of Wellington, New Zealand.

Afigbo, A. (1981). Ropes of sand: Studies in Igbo history and culture. Ibadon: Oxford University Press.

Ainsley, K. (2005). Sky woman: Indigenous women who have shaped, moved or inspired us. In S. Laronde (Ed.). Ancestral harvest. Canada: Theytus Books Ltd.

Akiwenzie-Damm, K. (2001). (Ad)dressing our words: Aboriginal perspective on Aboriginal literatures. In A. Ruffo (Ed.), Erotica, indigenous style. Canada: Theytus Books Ltd.

Allender, R. (1951). Disordered Cinema. Landfall 5.4.

Andrews, C. (2002). Developing a nursing speciality - Plunket nursing 1905-1920. Unpublished Masters of Arts (Applied) in Nursing thesis, Victoria University of Wellington, New Zealand.

Armstrong, J. (1998). The disempowerment of First North American Native Peoples and empowerment through their writing. In D. Moses \& T. Goldie (Eds.), An anthology of Canadian native literature in English. Oxford: Oxford UP.

Atkins, S., \& Murphy, J. (1993). Reflections: A review of the literature. Journal of Advanced Nursing, 18, 1188-1192. 
Atkinson, R. (1998). The life story interview. Thousands Oaks. CA: Sage.

Attwood, B. \& Magowan, F. (2001). Telling Stories: Indigenous history and memory in Australia and New Zealand. Wellington: Bridget Williams Books Ltd.

$\mathrm{Au}, \mathrm{K}$. (1997). Schooling, literacy and cultural diversity in research and personal experience. In A. Neumann \& P. Peterson (Eds.), Women, research and autobiography in education (pp. 71-90). New York: Teachers College Press.

Barlow, C. (2003). Tikanga Whakaaro: Key concepts in Maori culture. Revised (Ed.). Auckland: Oxford University Press.

Bataille, G., \& Sands, K. (1984). American Indian Women telling their lives. Lincoln: University of Nebraska.

Batten, J. (2005). Celebrating the Southern seasons: Rituals for Aotearoa. Auckland: Random House.

Battiste, M. (2000). Reclaiming Indigenous voice and vision. In M. Battiste (Ed.). Unfolding the lessons of colonisation/xvi. Vancouver: UBC Press.

Beckett, J. (2001). Autobiography and testimonial discourse in Myles Lalor's oral history. In B. Attwood \& F. Magowan (Eds.), Telling stories: Indigenous history and memory in Australia and New Zealand. Wellington: Bridget Williams Books Ltd.

Behrendt, L. (1993). Black women and the feminist movement: Implications for Aboriginal Women in rights discourse. Australian Feminist Law Journal, 1: 31.

Behrendt, L. (2004). Home. St Lucia: University of Queensland Press.

Behrendt, L. (2005). Law stories and life stories: Aboriginal women, the law and Australian society. Routledge: Taylor and Francis Group.

Best, E. (1924). The Maori. Vol. 1. Wellington: Harry H. Tombs. 
Best, E. (1974). The Maori as he was. Wellington: Government Printer.

Binney, J. (2005). A life of Thomas Kendall: The legacy of guilt. Auckland: Oxford University Press.

Binney, J., \& Chaplin, G. (2004). Nga Morehu: The Survivors. Auckland: University Press Ltd.

Bin-Sallik, M. (2005). In our own right: Black Australian nurses' stories. In S. Goold \& K. Liddle (Eds.), Beyond expectations: From nursing to academia. Queensland: eContent Management Pty Ltd.

Bishop, R. (1996). Collaborative research stories: Whakawhanaungatanga. Palmerston North: Dunsmore Press.

Bishop, R. \& Glynn, T. (1999).Culture counts: Changing power relations in education. Palmerston North: Dunsmore Press.

Black, T., Marshall, P., \& Irwin, K. (2003). Maori language nests in NZ: Te Koohanga reo, 1982 - 2003. Paper presented at the United Nations Permanent Forum on Indigenous Issues, New York, United States of America.

Blaeser, K. (1996). Gerald Vizenor: Writing in the oral tradition. Norman: University of Oklahoma Press.

Brewster, A. (1996). Reading Aboriginal women's autobiography. Sydney: Sydney University Press.

Broughton, R. (1979). The origins of ngaa rauru kiitahi. Unpublished Masters of Arts (Applied) in Maori Studies thesis, Victoria University of Wellington, New Zealand.

Buck, P. (1949). The coming of the Maori. Wellington: Whitcombe and Tombs.

Buck, P. (1958). The coming of the Maori $\left(2^{\text {nd }}\right.$ ed.). Wellington: Whitcombe and Tombs. 
Bulan, R. (2005). Leadership and dispute resolution among the Kelabit in Sarawak, Malaysia: Adapting to the changing social environment. Paper presented the $7^{\text {th }}$ World Indigenous Peoples' Conference on Education, Hamilton, New Zealand.

Bull, S. (2005). The power of dance: Bringing dance and music into the museum. Paper presented at the $7^{\text {th }}$ World Indigenous Peoples' Conference on Education, Hamilton, New Zealand.

Cajete, G. (2000). Reclaiming indigenous voice and vision. In M. Battiste (Ed), Indigenous knowledge: The Pueblo metaphor of indigenous education.Vancouver: UBC Press.

Campbell, D. (1979). A tribal model of the social system vehicle carrying scientific knowledge. Knowledge: Creation, Diffusion, Utilization 1: 181-201.

Carter, L. (2004). Whakapapa and the state: Some case studies on the impact of central Government on the traditionally organised Maaori groups. Maori Studies, University of Auckland, New Zealand.

Christian, B. (1980). Black women novelists: The development of a tradition, 1892-1976. Westport, CT: Greenwood Press, 239.

Churchward, F. (1991). He ara hou: "The family model": The family-group model as a pedagogical intervention in Maori schooling crisis. Unpublished Masters of Philosophy in Education thesis, University of Auckland, New Zealand.

Clandinin, J., \& Connelly, M. (2000). Narrative inquiry: Experience and story in qualitative research. San Francisco: Jossey-Bass.

Clareburt, J. (1992). He marae mo te kura: The changing role of a school-based marae. Unpublished Masters in Education thesis, University of Auckland, New Zealand. 
Clark, M. (1989). Enrolled nurses workshop: Opening address. In Workforce Development Group. Report on enrolled nurses workshop. March 1-2. Wellington: Department of Health.

Connor, D. (1995). Ko te hononga mauri, ko te hononga wairua, ko te hononga mana o te wahine: The resurgence of mana wahine: A response to "prisonization": Histories, reflections and stories. Unpublished Masters of Arts (Applied) in Education thesis, University of Auckland, New Zealand.

Crazy Bull, C. (1997). A Native conversation about research and scholarship. Tribal College Journal of American Indian Higher Education, 9(1), 17-23.

Crier, B. (2005). Maskwacis oral tradition and history - A Dialogue: The story that has not been told. Paper presented at the $7^{\text {th }}$ World Indigenous Peoples' Conference on Education, Hamilton, New Zealand.

Csak, N. (2002). What's important when you're six?: Valuing children's oral stories. Language Arts, 7(9), 8-497.

Cunningham, C. (2000). A framework for addressing Maori knowledge in research, science and technology. Journal of Community Health and Clinical Medicine for the Pacific, Vol 7(1), 62-69.

Curnow, J. (1958). Wiremu Maihi Te Rangikaheke: His life and work. Journal of the Polynesian Society, 94: 97-147.

Damico, J., Oelschlaeger, M., \& Simmons-Mackie, N. (1999). Qualitative methods in aphasia research: Conversation analysis. Aphasology, 13, 667-680.

Davis, M. (2006). Oral conversation. Hui conducted at Ngatokowaru marae, Levin, New Zealand.

Denzin, N., \& Lincoln, Y. (1994). The 'fifth moment' In N. Denzin \& Y. Lincoln (Eds.). Handbook of qualitative research. (pp.575-576). London: Sage. 
Diamond, P. (2004). A fire in your belly: Maori leaders speak. Wellington: Huia Publishers.

Dickelmann, N. (2001). Narrative pedagogy: Heideggerian hermeneutical analysis of the lived experiences of students, teachers and clinicians. Advance in Nursing Sciences, 23(3), 53-71.

Donley, J. (1996). The power of women. Paper presented at the New Zealand College of Midwives 1996 Conference, Lincoln University, Canterbury, New Zealand.

Dow, D. (1994). Collaborative writing in cyberspace: A case study. In J. Steele \& J. Hedberg (Eds.), Learning environment technology: Selected papers from LETA 94, 45-51. Canberra: AJEJ Publications.

Dow, D. (1999). Maori health and Government Policy 1840-1940. Auckland: Publishing Press Ltd.

Drabek, A. (2005). Alutiiq collaborative leadership for Native education and cultural revitalisation. Paper presented at the $7^{\text {th }}$ World Indigenous Peoples' Conference on Education, Hamilton, New Zealand.

Driskill, Q. (2005). Sky women: Indigenous women who have shaped, moved or inspired us. In S. Loronde (Ed.), Beginning Cherokee. Canada: Theytus Books Ltd.

Dubreuil, C. (2005). Sky women: Indigenous women who have shaped, moved or inspired us. In S. Loronde (Ed.), Her name is Peramonkoro! Canada: Theytus Books Ltd.

Durie, A. (1998). Proceedings of Te Oru Rangahau. Maori Research and Development Conference, Department of Maori Studies, Massey University, Palmerston North, New Zealand.

Durie, E. (1994). Custom Law. Address to the NZ Society for Legal and Social Philosophy. Victoria University of Wellington, New Zealand. 
Durie, M. (1989). The Treaty of Waitangi and Health Care. New Zealand Medical Journal, 102, 283-285.

Durie, M. (1998). Whaiora: Maaori health development. Auckland: Oxford University Press.

Durie, M. (1999). Whanau development and Maori survival. The challenge of time: A Millennium address. In Te Pumanawa Hauora and Ministry of Health (Eds.), Proceedings of Te Hau o te Whanau: Whanau Health and Development Conference, (pp. 77-90). Ministry of Health, Wellington, New Zealand.

Durie, M. (2000). Contemporary Maori Development: Issues and broad directions. Department of Development Studies, Waikato University, New Zealand.

Durie, M. (2002). Te Mana, Te Kawanatanga: The politics of Maori self-determination. Auckland: Oxford University Press.

Durie, M. (2003a). Nga Kahui Pou: Launching Maori futures. Wellington: Huia Publishers.

Durie, M. (2003b). Mauri Ora: The dynamics of Maori health. Auckland: Oxford University Press.

Durie, M. (2003c). Tino Rangatiratanga: Maori self determination, in He Pukenga Korero, Vol 2(2): 120-124.

Durie, M. (2004). Maori. In C. Ember \& M. Ember (Eds.). Encyclopaedia of medical anthropology: Health and illness in the world's culture, (pp. 815-822). New York: Kluwer Academic/Plenum.

Durie, M. (2005). Te Tai Tini: Transformations 2025. Paper presented to the hui Taumata 2005, Wellington, New Zealand.

Durie, M. (2006). Measuring the effectiveness of Rongoa Maori. Paper presented to a Rongoa conference, Te Wananga o Raukawa, Otaki, New Zealand. 
Edmonds, M., \& Clark, E. (1989). Voice of the winds: Native American legends. New York: Facts on File.

Egudu, R. (1981). Achebe and the Igbo narrative tradition. Research in African literatures, 12(1): 43-51.

Einhorn, L. (2000). The Native American oral tradition: Voices of the spirit and soul. Westport, CT: Praeger.

Eshkakogan, N., \& Half, A. (2005). The double estrangement of Aboriginal elders in Canada. Paper presented to the $7^{\text {th }}$ World Indigenous Peoples' Conference on Education, Hamilton, New Zealand.

Etter-Lewis, G. (1991). Women's words: The feminist practice of oral history. In S. Gluck \& D. Patai (Eds.), Black women's life stories: reclaiming self in narrative texts. New York: Routledge.

Fee, M. (1997). Writing orality: Interpreting literature in English by Aboriginal writers in North America, Australia and New Zealand. Journal of Intercultural Studies 18(1), 2339.

Firth, R. (1959). The Economics of the New Zealand Maori. Wellington: Government Printer.

Fisher, D. (Eds.). (1988). The third women: Minority women writers of the United States. Boston: Houghton Mifflin Co, 148.

Flintoff, B. (2005). Taonga puuoro: Singing treasures, the musical instruments of the Maori. Nelson: Craig Potton Publishing.

Foucault, M. (1980). Power/Knowledge: Selected interviews and other writings. New York: Pantheon Books. 
Fox, R. (1999). The antenatal education needs of Maori women (in the Tainui region) and implications for midwifery practice. Unpublished Master of Arts (Applied) in Midwifery thesis, Victoria University of Wellington, New Zealand.

Freud, S. (1953). In J. Strachey, (Ed.), The standard edition of the complete psychological works of Sigmund Freud. London: Hogarth Press, 300.

Freyerabend, P. (1975). Against method. Humanities Press: London.

Gardner, H., Czikszentmihalyi, M., \& Damon, W. (2001). Good work: When excellence and ethics meet. New York: Basic Books.

Garfinkel, H. (1967). Studies in ethnomethodology. Englewood Cliffs, NJ: Prentice Hall.

Gillespie, M. (1975). Editorial. Essence, May, 3.

Glover, M. (1997). Kaupapa Maori health research. A developing discipline. Paper presented at the hui Whakatipu, Whaiora marae, Otara, Auckland, New Zealand.

Goffman, E. (1983). The interaction order. American Sociological Review 48: 1-17.

Goold, S. (2005). In our own right: Black Australian nurses' stories. In S. Goold and K. Liddle (Eds.), Keeping your eye on the prize! Queensland: eContent Management Pty Ltd.

Goold, S., \& Liddle, K. (Eds.). (2005). In our own right: Black Australian nurses' stories. Queensland: eContent Management Pty Ltd.

Gordimer, N. (1975). Livingstone's companions: Stories by Nadine Gordiner. Harmondsworth: Penguin.

Gordimer, N. (2006). Encyclopaedia Britannica. Retrieved 28 November, 2006 from Encyclopaedia Britannica online: http:/www.britannica.com/eb/article - 9037412. 
Grace, P. (2006). Small holes in the silence. Auckland: Penguin.

Grosvenor, V. (1970). Vibration cooking. New York: Doubleday.

Gudmunsdottir, S. (1995). The narrative nature of pedagogical content knowledge. In $\mathrm{H}$. McEwan and H. Egan (Eds.). Narrative in Teaching learning and research, (pp. 24-38). New York: Teachers College.

Haami, B. (2004). Puutea whakairo: Maaori and the written word. Wellington: Huia Publishers.

Hampton, E. (1995). Towards a redefinition of Indian education. In M. Batiste \& J. Barman (Eds.). First nations education in Canada: The circle unfolds. Vancouver: UBC Press.

Hanson, F. (1982). Female pollution in Polynesia. Journal of Polynesian Society, 91, 335.

Harjo, J. (2005) Sky women: Indigenous women who have shaped, moved or inspired us. In S. Laronde (Ed.), The woman who fell from the sky. Canada: Theytus Books Ltd.

Harker, D. (2000). Nurses as patients: The stories of two women nurse educators as recipients of nursing care. Unpublished Masters of Arts (Applied) in Nursing thesis, Victoria University of Wellington, New Zealand.

Hemsley, M. (2004). Walking in two worlds: Transformational journeys of nurse healers. Unpublished Doctor of Philosophy in Nursing thesis, Southern Cross University, Lismore, Australia.

Heritage, J. (1995). Conversation analysis: Methodological aspects. In U. Quasthoff (Ed.), Aspects of oral communication. Berlin/New York: Walter de Gruyter.

Hertz, R. (Ed.). (1997). Reflexivity and voice. Thousand Oaks, CA: Sage. 
Heiss, A. (2001). (Ad)dressing our words: Aboriginal perspectives on Aboriginal literatures. In A. Ruffo (Ed.), Aboriginal identity and its effect on writing. Canada: Theytus Books Ltd.

His Horse is Thunder, D., \& Gipp, G. (2003). Chief and visionaries: AIHEC molds leadership initiative to match tribal values. Tribal College Journal of American Higher Education, 15(1), 15-16.

Hodson, J. (2005). Aboriginal, Research in Canada: The Power to heal. Paper presented at the $7^{\text {th }}$ National World Indigenous Peoples' Conference on Education, Hamilton, New Zealand.

Hohepa, M. (1990). Te Koohanga reo hei tikanga ako i te reo Maori. Te Koohanga reo as a context for language learning. Unpublished Masters of Arts (Applied) in Education thesis, University of Auckland, New Zealand.

Holdaway, M. (2002). A Maori model of primary health care nursing. Unpublished Doctor of Philosophy in Nursing thesis, Massey University, Palmerston North, New Zealand.

hooks, b. (2000). Where we stand: Class matters. Boston: South End Press.

Huggins, J. (1994). A contemporary view of Aboriginal women's relationship to the white women's movement. In N. Grieve \& A. Burns (Eds.), Australian Women Contemporary Feminist Thought. Melbourne: Oxford University Press.

Huggins, R. \& Huggins, J. (1994). Aunty Rita. Canberra: Aboriginal Studies Press.

Human Rights and Equal Opportunity Commission, (1997). Bringing them home, report of the National Inquiry into the separation of Aboriginal and Torres Strait islander children from their families. Canberra: Human Rights and Equal Opportunity Commission.

Huron, D. (2005). Sky woman: Indigenous women who have shaped, moved or inspired us. In S. Laronde (Ed.), My aunt's kindness made a difference. Canada: Theytus Books Ltd. 
Hutchings, J. (2006). State of the Maori Nation twenty-first-century issues in Aotearoa. In M. Mulholland and contributors, (Re) negotiating (Bi) cultural environmental management under the resource management act. Auckland: Reed Publishers (NZ) Ltd.

Ihimaera, W. (2003). Growing up Maori. Auckland: Tandem Press.

Inyallie, J. (2005). Sky woman: Indigenous women who have shaped, moved or inspired us. In S. Laronde (Ed.). Salmon Bone women. Canada: Theytus Books Ltd.

Irwin, J. (1984). An introduction to Maori religion: Special studies in religion, Number 4. (p.11). South Australia: Australian Association for the study of religions.

Irwin, K. (1992). Maori research methods and processes. An exploration and discussion. Paper presented to the joint New Zealand Association of Research Education/ Australian Association for Research in Education Conference, Geelong, Australia.

Irwin, K. (1995). Maori research methods and processes: An exploration. Sites, 28. 25-43.

Jacobs, R. (2006). Oral conversation. Hui conducted at Ngatokowaru marae, Levin, New Zealand.

Jackson, M. (1988). The Maori and the criminal justice system. A new perspective: He Whaipaanga hou. Part 11: Department of Justice.

Jahnke, R. (2006). State of the Maori Nation twenty-first-century-issues in Aotearoa. In M. Mulholland and contributors. Maori Art towards the Millennium. Auckland: Reed Publishers (NZ) Ltd.

Jenkins, K. (1986). Reflection on the Status of Maori women. Unpublished paper. University of Auckland, New Zealand.

Jenkins, K. (1991). Te ihi te mana, te wehi o te ao tuhi: Maori print literacy for 1814-1855: Literacy, power and colonisation. Unpublished Masters in Education thesis, University of Auckland, New Zealand. 
Johns, C. (1995). Framing learning through reflection within Carper's Ways of knowing in nursing. Journal of Advanced Nursing, 22, 226-234.

Johns, C., \& Freshwater, D. (2005). Transforming nursing through reflective practice. Oxford: Blackwell Publishers.

Jones, R. (2000). Diagnosis in traditional Maori healing: A contemporary urban clinic. Journal of Community Health and Clinical Medicine for the Pacific, Vol 7(1), 17-24.

Kaa, W., \& T. (Eds.). (1996). Apirana Ngata. Ana tuhinga i te reo Maori. Wellington: Victoria University Press.

Ka'ai, T. (1990). Te hiringa taketake: Mai te Koohanga reo i te kura-Maori pedagogy: Te Koohanga reo and the transition in school. Unpublished Masters in Philosophy and Education thesis, University of Auckland, New Zealand.

Ka'ai, T., \& Higgins, R. (2004). Maori worldview. In T. Ka'ai, Moorfield, Reilly and S. Mosley (Eds.), Ki te whaiao: An introduction to Maori culture and society. Auckland: Pearson Education New Zealand Ltd.

Kahakalau, K. (2005). Indigenous Heuristic Action Research Confirms success of Nativedesigned and controlled charter school. Paper presented at the $7^{\text {th }}$ World Indigenous Peoples' Conference on Education, Hamilton, New Zealand.

Kahakalau, K., Kahakalau, N., \& Pahi'o, K. (2005). Native Hawaiian charter school alliance spearheads Hawai' $i$ 's indigenous education. Paper presented at the $7^{\text {th }}$ World Indigenous Peoples' Conference on Education, Hamilton, New Zealand.

Kawa, E. (2001). Constitutional law of Papua New Guinea. Sydney: Law Book, Co.

King, M. (1997). Nga Iwi o te motu: 1000 years of Maori history. Auckland: Reed Publishers (NZ) Ltd. 
King, M. (2001). Nga Iwi o te motu: 1000 years of Maori history. Revised. Auckland: Reed Publishers (NZ) Ltd.

King, M. (2003). The penguin history of New Zealand. Auckland: Penguin Books.

Knox, C. (2005). Whakapuumau te Mauri: Values - based Maaori organisations. Unpublished Doctor of Philosophy in Maori Studies thesis, Massey University, Palmerston North, New Zealand.

Koch, T., \& Harrington, A. (1998). Reconceptualising rigour: The case for reflectivity. Journal of Advanced Nursing, 28(4), 882-890.

Kuhn, T. (1962). The structure of scientific revolution. Chicago: University of Chicago Press.

Lange, R. (1999). May the people live a history of Maori health development 1900-1920. Auckland: University Press New Zealand.

Lather, P. (1991). Getting smart: Feminist research and pedagogy with/in the postmodern. New York: Routledge.

Lavoie, J. (2003). Indigenous primary care services in Australia, Canada and New Zealand: Report on four case studies. Report produced for the Whaiti of Raukawa Hauora, Otaki, New Zealand.

Leander, B. (2001). Oral and written Naahualt: Literature from ancient and modern Mexico. Paper presented at the International Symposium on Indigenous identities: Oral, written expression and new technologies, Paris, France.

Lee, N. (2005). Exploring Naa wahine leadership from a Native Hawaiian perspective. Paper presented at the $7^{\text {th }}$ World Indigenous Peoples' Conference on Education, Hamilton, New Zealand. 
Leininger, M. (1991). Culture care diversity and universality: A theory of nursing. New York: National League for Nursing Press.

Leo, A. (2005). Kumu Honua Mauli Ola: An Indigenous way to life. Paper presented at the $7^{\text {th }}$ World Indigenous Peoples' Conference, Hamilton, New Zealand.

Lincoln, Y., \& Guba, E. (1985). Naturalistic inquiry. Newbury Park: Sage: Publishers.

Lincoln, Y,, \& Guba, E. (1994). Handbook of qualitative research. In N. Denzin \& Y. Lincoln, (Eds.), Competing paradigms in qualitative research. (pp 105-117). Thousand Oaks: Sage Publication.

Lincoln, Y., \& Guba, E. (2000). Handbook of qualitative research ( $2^{\text {nd }}$ ed.). In N. Denzin \& Y. Lincoln, (Eds.), Paradigmatic controversies, contradictions and emerging confluences. (pp. 163-188). Thousand Oaks: Sage Publication.

Lundgren, J. (1995). Being a half-bred: Discourses of race and cultural syncreticity in the works of three Metis women writers. Canadian Literature 147, 62-77.

Makereti. (1986). The old time Maori. Auckland: New Women's Press.

Managan, H. (2003). Matauranga Maori concepts. Paper presented to Kaihautu Board, Te Wananga o Raukawa, Otaki, New Zealand.

Maori Women's Welfare League (1993). Te Timatanga a tatau tatau: Early stories from founding members of Maori women's Welfare League. Maori Women's Welfare League. Wellington: Bridget Books Ltd.

Marsden, M. (1992). God, man and universe: A Maori view. In M. King (Ed.), Te Ao Hurihuri: Aspects of Maoritanga. (pp. 117-137). Auckland: Reeds Books.

Marsden, M. (1995). God, man and universe. A Maori view. In M. King (Ed.), Te Ao Hurihuri: The world moves on. Wellington: Hicks Smith and Sons Ltd. 
Marsden, M. (1997). Te Ao Marama: An historical paradigm? In C. Royal (Ed.). Paper presented to a history hui convened by Te Pouhere Korero. Otaki: Te Wananga o Raukawa.

Marsden, M. (2003). The woven universe: Selected writings of Rev. Maori Marsden. In C. Royal (Ed.). Published by the estate of Maori Marsden, Masterton, New Zealand.

Marsden, M. (2004). In C. Royal (Ed.). Seeing the prism in the water, hearing the voice in the forest. Paper presented at Te Wananga o Aotearoa, Te Awamutu, New Zealand.

Martin, M. (2000). A grain of salt ... A contemplative study of natural form in nursing, developed in collaboration with people in life-threatening and life-challenging situations to reveal untold stories of healing. Unpublished Doctor of Philosophy in Nursing thesis, Victoria University of Wellington, New Zealand.

Masikad, P. (2005). Reclaiming the place: The case of the indigenous place-bound movement in Taiwan. Paper presented at the $7^{\text {th }}$ World Indigenous Peoples' Conference on Education, Hamilton, New Zealand.

Mason, J. (1996). Qualitative researching. London: Sage.

McAdams, D. (2006). The redemptive self: Stories Americans live by. New York: Oxford University Press.

McClusky, N. (2005). Nga Wheako a tetahi nehi Maori i roto i te kooti mo Nga TupapakuMe pehea te whakapai?: A Maori nurses experience in the coroners court-How can it be better? Unpublished Masters of Arts (Applied) in Nursing thesis, Victoria University of Wellington, New Zealand.

McEldowney, R. (2002). Shape-shifting: Stories of teaching for social change in nursing. Unpublished Doctor of Philosophy in Nursing thesis, Victoria University of Wellington, New Zealand. 
McLeod, N. (2001). (Ad)dressing our words: Aboriginal perspectives on Aboriginal literatures. In A. Ruffo (Ed.), Coming home through stories. Canada: Theytus Books Ltd.

McRae, J. (2000). Maori oral tradition meets the book. In P. Griffiths, P. Hughes \& A. Loney (Eds.), Ke te whaiao: Introduction to Maori culture and society. Auckland: Pearson Education.

McRae, J. (2004). Nga tuhituhinga reo Maori: Literature in Maori. In T. Ka'ai, Moorefield, Reily and S. Mosley (Eds.), Ke te whaiao: Introduction to Maori culture and society. Auckland: Pearson Education.

Mead, A. (2001). Misappropriation of cultural and intellectual property rights of indigenous peoples'. Paper presented at the United Nations Conference on Indigenous Peoples and Racism, Sydney, Australia.

Meads, H. (1984). Nga tikanga tuko iho a te Maori: Customary concepts of the Maori. Wellington: Victoria University, New Zealand

Meads, H. (2003). Tikanga Maori: Living by Maori values. Wellington: Huia Publishers.

Melesis, A. (1990). Being and becoming healthy: The core of nursing knowledge. Nursing Science Quarterly, 3(3), 107-114.

Metge, J. (1995). New growth from old: The whanau in the modern world. Wellington: Victoria University Press.

Mezirow, J. (1991). Transformative dimensions of adult learning. San Francisco: JosseyBass.

Mikaere, A. (1995). The balance destroyed: Consequence for Maori women of the colonisaiton of tikanga Maori. Unpublished Masters in Jurisprudence thesis, Waikato University, New Zealand. 
Mikaere, A. (2003). The balance destroyed: Consequences for Maori women of the colonisation of tikanga Maori. Mana Wahine Monograph series: Monography one. International Research Institute for Maori and Indigenous Education, University of Auckland, New Zealand.

Miller, R. (2000). Researching life stories and family histories. London: Sage.

Ministry for the Environment, (1994). Resource Management consultation with Tangata Whenua. Wellington: Ministry for the Environment.

Ministry of Health, (2005). District Health Boards. Retrieved October 28, 2006 from http://moh.govt.nz/districthealthboards.

Moon, P. (2003). Tohunga Hohepa Kereopa. Auckland: David Lang Publications Ltd.

Morgan, S. (1987). My Place. Freemantle: Freemantle Arts Centre.

Morris, L. (1996). Black sistas: Indigenous women and the welfare. In K. Bai (Ed.), DIY Feminism. Sydney: Allen and Unwin.

Moreton-Robinson, A. (2000). Talkin' up to the white women indigenous women and feminism. St Lucia: University of Queensland Press.

Moses, D. (2001). (Ad)dressing our words: Aboriginal perspective on Aboriginal literature. In A. Ruffo (Ed.), A syphilitic western making "The...medicine shows". Canada: Theytus Books Ltd.

Moustakas, C. (1990). Heuristic research: Design, methods and application. Newbury Park, CA: Sage.

Mulligan, E. (2003). Tihei Mauri Ora, the breath of life. The conceptualisation of Tihei Mauri Ora with a Bachelor of Midwifery programme. Unpublished Masters of Art (Applied) in Nursing thesis, Victoria University of Wellington, New Zealand. 
Myers, V. (1986). (Ed.). Head and shoulders. Auckland: Penguin Books.

Myers, V. (1986). Head and shoulders. In V. Meyers (Ed.), Mira Szaszy. Auckland: Penguin Books.

Nabokov, P. (2002). A forest of time: American Indian ways of history. Cambridge, UK: Cambridge University Press.

Nanton, P. (1995). Making spaces for orality on its own terms. In S. Brown (Ed.). The pressures of the text: Orality, texts and the telling of tales. Birmingham: University of Birmingham.

Narogin, M. (1990). Writing from the fringe: A study of modern Aboriginal literature. Melbourne: Hyland House.

Ngata, A. (1928). Anthropology and the Government of Native race in the Pacific. The Australasian Journal of Psychology and Philosophy, Vol, V1, No. 1.

Nicholson, I. (2003). Ngati Toa Brief of Evidence - Te Tau Ihu Inquiry Wai 207, 785 Claim, (p. 9.). Porirua, New Zealand.

Nicholson, I. (2005). Critical analysis of one marae. Hui conducted at Ngatokowaru marae by M. Taiaroa and R. Taiaroa, Levin, New Zealand.

Nicholson, I. (2006). Oral conversation. Hui conducted at Ngatokowaru marae, Levin, New Zealand.

Nobel, J. (1978). Beautiful, also, are the souls of sisters: A history of the black women in America. Englewood Cliffs, New Jersey: Prentice-Halls Inc., 63.

New Zealand Ministry of Health. (1984). Hui Whakaoranga: Maori health planning Workshop. Hoani Waititi marae: New Zealand Ministry of Health. 
Nielson-Hornblow, C. (2004). Three key elements: Mental health delivery towards Maaori. Unpublished Masters of Art (Applied) in Nursing thesis, Victoria University of Wellington, New Zealand.

Oakley, A. (1981). Interviewing women: A contradiction in terms. In H. Roberts (Ed.). Doing feminist research. (pp. 30-61). New York: Routledge.

Ohia, M. (2004). Oral conversation. Hui conducted at Te Wananga o Raukawa, Otaki, New Zealand.

Okello, E. (2006). Cultural explanatory models of depression in Uganda. Sweden: Karolinska University Press.

Ong, W. (1995). Orality and literacy: The technologising of the word. London: Routledge.

Orbell, M. (1998). A concise encyclopaedia of Maori myths and legend. Christchurch: Canterbury University Press.

O'Regan, H. (2006). State of the Maori Nation twenty-first-century issues in Aotearoa. In Malcolm Mulholland and contributors. State of the reo nation: Maori language learning. Auckland: Reed Publishing (NZ) Ltd.

O'Reilly, M. (2002). A narrative inquiry into care of the dying in an acute care setting from the point of view of family. Unpublished Masters of Arts (Applied) in Nursing thesis, Victoria University of Wellington, New Zealand.

Panford, S., Nyaney, M. O. G., Amoah, S.O., \& Aidoo, N. G. (2001). Using folk media in HIV/AIDS prevention in rural Ghana. American Journal of Public Health, 91(10), $1559-1562$.

Patterson, J. (1992). Exploring Maori values. Palmerston North: Dunsmore Press.

Patton, M. (1990). Qualitative evaluation and research methods. ( $2^{\text {nd }}$ ed.). California, USA: Sage. 
Pawan, C. (2005). Indigenous language education in Taiwan. Paper presented at the $7^{\text {th }}$ Indigenous Peoples' Conference on Education, Hamilton, New Zealand.

Peacock, J., \& Holland, D. (1993). The narrated self: Life stories in process, Ethos, Vol. 21 (4): $367-383$.

Penfold, M. (2000). Nga waiata aroha a hekepia: Love sonnents by Shakespeare: Nine sonnets/translated into Maori. Holloway Press, University of Auckland.

Pere, R. (1982). Ako: Concepts and learning in Maori tradition. Department of Sociology, University of Waikato. Working paper No 17, p. 7.

Pere, R. (1984). Te Oranga o te whanau (The health of the family), in Hui Whakaoranga Maori health planning workshop. Wellington: Department of Health.

Pere, R. (1991). Te Wheke: A celebration of infinite wisdom. ( $2^{\text {nd }}$ ed.). Gisborne: Ao Ako Global Learning, New Zealand.

Pere, R. (1997). Te Wheke: A celebration of infinite wisdom. Gisborne: Ako Ako Global Learning, New Zealand.

Phillis, TeOh. (2001). Eruera Manuera. Wellington: Huia Publishers.

Pihama, L. (1993). Tungia te ururu, kia tupu whakaritorito te tupu o te harakeke: A critical analysis of parents as first teachers. Unpublished Masters of Arts (Applied) in Education thesis, University of Auckland, New Zealand.

Piquemal, N. (2001). Four principles to guide research with Aboriginals. Policy Options, pp. 49-51.

Polkinghorne, D. (1988). Narrative knowing and the human sciences. New York: SUNY. 
Port, R. (1995). He mate huhua: He tirohanga Maori, Maori attitudes to disability: Clubfoot. Unpublished Master in Education thesis, University of Auckland, New Zealand.

Potatau, H. (1991). He Hokinga Mahara: Na Hemi Potatau. Auckland: Longman Paul.

Potiki, R. (1992). Stones in my mouth: Poems. Tamakimakaurau, N.Z.: IWA.

Poupart, J. (2003). To build a bridge 11: American Indians in Minneapolis and Hennepin county. St. Paul, MN: American Indian Policy Centre.

Pratt, M., \& Fiese, B. (2004). (Eds.). Family stories and the life course: Across time and generations. Mahwah, New Jersey: Lawrence Erlbaum.

Puketapu, B. (2000). Maori Organisations and Contemporary Maori Development. Unpublished Doctor of Philosophy in Management thesis, Massey University, Palmerston North, New Zealand.

Ramsden, E. (1951). Rangiatea: The story of the Otaki Church, it's first pastor and its people. Wellington: A., \& A. Reed.

Ramsden, I. (1992). Kawa Whakaruruhau: Guidelines for nursing and midwifery education. Wellington: Nursing Council of New Zealand.

Ramsden, I. (2002). Cultural safety and nursing education in Aotearoa and Te Waipounamu. Unpublished Doctor of Philosophy in Nursing thesis, Massey University, Palmerston North, New Zealand.

Rangihau, J. (1992). Being Maori. In M. King (Ed.), Te ao Hurihuri: Aspects of Maoritanga. (pp. 185-190). Wellington: Reed Publishers (NZ) Ltd.

Reed, A., \& A. (1999). Concise Maori encyclopaedia. Wellington: Reed Publishing (NZ) Ltd. 
Reedy, A. (1997). Nga korero a pita Kapiti. Christchurch: Canterbury University Press.

Rewiri, K. (2005). Exert on Rewiri accomplishments. Wellington: Ferriers Gallery.

Riddell, B. (2001). Mataoroa: The living face. In S. Adsett, C. Whiting \& W. Ihimaera (Eds.). Auckland: David Bateman.

Roberts, R., \& Wills, P. (1998). Understanding Maori epistemology: A scientific perspective. In $\mathrm{H}$. Wautischer (Ed.), Tribal epistemologies: Essays in the philosophy of anthropology. Ashgate, England.

Rochford, N. (2004). As a nurse in the family: three women's stories of what it means for... Unpublished Masters of Arts (Applied) in Nursing thesis, Victoria University of Wellington, New Zealand.

Royal, C. (1997a). Te Ao Marama: An historical paradigm? Paper presented to the History hui convened by Te Pouhere Korero, Te Wananga o Raukawa, Otaki, New Zealand.

Royal, C. (1997b). Some on researching tribal histories and traditions. A paper presented to the National Library, Wellington, New Zealand.

Royal, C. (1997c). Maori human development learning theory. Mai i Rangiatea: Maori wellbeing and development. Auckland: Auckland University Press.

Royal, C. (1998a). Evidence of Charles Patrick Royal prepared for the Waitangi Tribunal in respect of Wai 718. A claim brought by Rongoa Herehere Wetere and others relating to funding of the three Wananga Maori, Wellington, New Zealand.

Royal, C. (1998b). Matauranga Maori: Paradigms and politics. Paper presented to the Ministry of Research and Technology, Wellington, New Zealand. 
Royal, C. (2000). Purakau: A genre of storytelling. Paper presented to the $10^{\text {th }}$ Biennial Conference of the History and Film Association of Australia and New Zealand, Wellington, New Zealand.

Royal, C. (2004). Seeing the prism in the water, hearing the voice in the forest. Paper presented to Te Wananga o Aotearoa, Te Awamutu, New Zealand.

Russell, M. (1977). An open letter to the academy. Quest 3: 77.

Ruth-Sahd, L. (2003). Reflective practice: A critical analysis of data based research studies and implications for nursing education. Journal of Nursing Education, 42(11), 488-496.

Sakej, J. (2000). Reclaiming indigenous voice and vision. In M. Battiste (Ed.), The context of the state of the nation. Vancouver: UBC.

Salmond, A. (1976). Hui: A study of Maori ceremonial gatherings. ( $2^{\text {nd }}$ ed.). Wellington: A.H. \& A.W. Reed.

Salmond, A. (2004). Hui: A study of Maori ceremonial gatherings. Wellington: A.H. \& A.W. Reed.

Sandelowski, M. (1993). Rigor or rigor mortis. The problem of rigor in qualitative research revisited. Advanced Nursing Sciences 16(2): 1-8.

Scheglogg, E. (1992). Repair after next turn: The latest structurally provided defence of intersubjectivity in conversation, American Journal of Sociology 98: 1295-1345.

Schwimmer, E. (1966). The world of the Maori. Wellington: Reed Publishers (NZ) Ltd.

Selby, R. (1999). Still being punished. Wellington: Huia Publishers.

Selby, J. (2006). Oral conversation. Hui conducted at Ngatokowaru marae, Levin, New Zealand. 
Selby, M. (2006). Oral conversation. Hui conducted at Ngatokowaru marae, Levin, New Zealand.

Severin, A. (2005). Sky woman: Indigenous women who have shaped, moved or inspired us. In S. Laronde (Ed.). Be who you are. Canada: Theytus Books Ltd.

Silko, L. (1997). Yellow woman and a beauty of the spirit: Essays on Native American life today. New York: Touchstone.

Silko, L. (1999). Gardens in the dunes. New York: Simon \& Schuster.

Simmons, D. (1976). The great New Zealand myth: A study of the discovery and origin traditions. Wellington: A. \& A. Reed.

Simmonds, D., \& Penfold, M. (2003). Nga tau rere: An anthology of ancient Maori poetry. Auckland: Reed Publishers (NZ) Ltd.

Slacks, H. (1984). Notes on methodology. In J. Atkinson and J. Heritage (Eds.). Structures of social action: Studies in conversation analysis, (pp. 2-17). Cambridge: Cambridge University Press.

Smith, G. (1997). The development of Kaupapa Maori: Theory and praxis. Unpublished Doctor of Philosophy in Education thesis, University of Auckland, New Zealand.

Smith, L. (1992). Maori women: Discourses, projects and mana wahine. In S. Middleton \& A. Jones (Eds.), Women and education in Aotearoa 2. Wellington: Bridget Williams Books.

Smith, L. (1994). In search of a language and a shareable imaginative world: E kore taku moe, e riro i a koe, Hecate, Vol. 20, No 2, 162-174.

Smith, L. (1995). Recentering Kaupapa Maori research. Paper presented to the Te Matawhanui Conference, Maori Studies Department, Massey University, Palmerston North, New Zealand. 
Smith, L. (1996). Nga aha o te kakahu Matauranga: The multiple layers of struggle by Maori in education. Unpublished Doctor of Philosophy in Education thesis, University of Auckland, New Zealand.

Smith, L. (1999). Decolonising methodologies: Research and indigenous peoples. Dunedin: NZ: University of Otago Press.

Smith, L. (2001). In J. Simon, L. Smith and F. Cram (Eds.), Civilising Mission?: Perception and representation of the native schools system. Auckland: Auckland University Press.

Smith, L. (2002). Kaupapa Maori Research. In M. Battiste (Ed.), Reclaiming indigenous voice and vision. Canada: UBC Press.

Smith, P. (1913). The lore of the Whare Wananga: Part 1- Kauwae-runga, Journal of Polynesia Society. Vol. 1, Wellington, New Zealand.

Smith, P. (1915). The lore of the Whare Wananga: Or teachings of the Maori college on religion, cosmogony and history. Written down by $\mathrm{H}$. Whatahoro from the teaching of Te Matorahanga and 2 Parts. New Plymouth: Memoirs of the Polynesian Society, Vols 111, IV.

Snedden, P. (2005). Pakeha and the Treaty: Why its our Treaty too. Auckland: Random House Book.

Standing Bear, L. (1988). Land of the spotted eagle. Lincoln Nebraska: University of Nebraska Press.

Strickson-Pua, M. (2006). Matua: Parent. Auckland: The Pohutakawa Press.

Stokes, E. (2001). Maori research and development. University of Waikato, Hamilton, New Zealand. 
Struthers, R. (2001). Conducting sacred research: An indigenous experience. Wicazo Sa Review, 16(1), 125-133.

Struthers, R., \& Peden-McAlpine, C. (2005). Phenomenological research among Canadian and United States indigenous populations: Oral traditions and quintessence of time. Qualitative Health Research, Vol 15(9), 1264-1276.

Suzuki, T. (1978). Japanese and the Japanese: Words in culture. Tokyo. New York: Kodansha International.

Taiaroa, H. (2001). Maori women and wellness. Unpublished Masters of Arts (Applied) in Nursing thesis, Victoria University of Wellington, New Zealand.

Tamasese, K., Peteru, C., \& Waldegrave, C. (2005). Ole Taeao Afua, The new morning: A qualitative investigation into Samoan perspectives on mental health and culturally appropriate services. Australian and New Zealand Journal of Psychiatry. Vol 39(4), 300-310.

Tau, T. (1999). Matauranga Maori as an epistemology. In A. Sharp \& P. McHugh (Eds.), Histories, power and loss: Uses of the past-A New Zealand commentary. Wellington: Bridget Books Ltd.

Taylor, B. (2000). Reflective Practice - A Guide for Nurses and Midwives. NSW, Australia: Allen \& Unwin.

Te Awekotuku, N. (1991). He tikanga whaakaro: Research ethics in the Maori community. A discussion paper presented to the Manatu Maori, Ministry of Maori Affairs, Wellington, New Zealand.

Te Puni Kokiri, (1993). Nga ia o te hinengaro Maori. Wellington: Te Puni Kokiri.

Ten fingers, K. (2005). Rejecting, revitalising and reclaiming Canada. Journal of Public Health, 96(1), 560-563. 
Ten Have, P. (1999). Doing conversation analysis: A practical guide. London: Sage Publications Ltd.

Te Rito, J. (2007). Te Tihoka me te karo: Struggles and transformation of Ngati Hinemanu of Omahu. Unpublished Doctor of Philosophy thesis, University of Auckland, New New Zealand.

Thomas, R. (1989). Oral traditions and written record in classical Athens. Cambridge: Cambridge University Press.

Tizard, J. (1940). The Maori school of learning: A study in psychology and folk lore. Unpublished Masters of Arts (Applied) in Philosophy thesis, Canterbury University, New Zealand.

Tucker, M. (1977). If everyone cared: Autobiography of Margaret Tucker. Ure Smith, Sydney, Australia.

Turia, T. (2005). Walking the talk: A collection of Tariana's papers. R. Selby (Ed.). Otaki: Te Wananga o Raukawa.

van Manen, M. (1997). From meaning to method. Qualitative Health Research, 7(3), 345369.

van Toorn, P. (2001). Indigenous Australia life writing tactics and transformation. In B. Attwood \& F. Magowan (Eds.), Telling stories: Indigenous history and memory in Australia and New Zealand. Wellington: Bridget Williams Books Ltd.

Vanderwerth, W. (1971). Indian oratory: Famous speeches by noted Indian chieftains. Norman: University of Oklahoma Press.

Vezeau, T. (1994). Narrative inquiry in nursing. In P. Chinn \& J. Watson (Eds.), Art and aesthetics in nursing, (pp.41-66). New York: National League of Nursing Press.

Walker, R. (1990). Ko Whawhai Tonu Matou: Struggle without end. Auckland: Penguin. 
Walker, R. (1992). Sovereignty: Te Tino Rangatiratanga. In D. Novitz \& B. Willmott. (Eds.), New Zealand in crisis. A debate about today's critical issue,. (pp .10). Wellington: GP Publications Ltd.

Walker, R. (1996). Nga pepa a ranganui: The Walker papers. Auckland: Penguin Books.

Walker, R. (1999). Nga kete Wananga. In P. Harrison (Ed.). A paradigm of the Maori view of reality. Auckland: Manakau Institute of Technology.

Walker, R. (2001). He Tipuna: The life and times of Sir Apirana Ngata. Auckland: Viking.

Walker, R. (2007). Oral conversation. Hui conducted at Te Wananga o Raukawa, Otaki, New Zealand.

Walsh-Tapiata, W. (1997). Raukawa social services: Origins and future direction. Waiho ma te iwi e whakrite. Kei a ratou te kaha ki te hapai ake I a ratou ki te ao marama. Leave it to the iwi to decide, for only they can take themselves into the future. Unpublished Masters in Social Work thesis, Massey University, Palmerston North, New Zealand.

Walters, M. (2004). Oral conversation. Hui conducted at Te Wananga o Raukawa, Otaki, New Zealand.

Washington, M. (1979). Midnight Birds: Stories of contemporary black women writers. Garden City. New York: Doubleday.

Westerman, T. (2006). The value of service provision for Aboriginal Australians: The benefits of starting from scratch. Paper presented to the Conference of the Australian Psychological Society, Auckland, New Zealand.

Wetere, K. (1988). Te Urupare Rangapu: Te Rarangi Kaupapa/Partnership perspectives: A policy statement. Wellington: Ministry of Maori Affairs. 
Whaitiri, R. (2006). State of the Maori Nation twenty-first-century issues in Aotearoa. In M. Mulholland and contributors, Maori literature: The power and beauty. Auckland: Reed Publishers (NZ) Ltd.

White, J. (1887). The ancient history of the Maori, his mythology and traditions. Vols, 1, 11, Wellington: Government Printer.

White, M. (1997). Narratives of therapist's lives. Adelaide: Dulwich Centre Publications.

Wilkinson, J. (1999). Implementing reflective practice. Nursing Standard, 13(2), 36-40.

Williams, H. (1957). A dictionary of the Maori language. Wellington: Government Printer.

Williams, H. (1971). A dictionary of the Maori language. ( $7^{\text {th }}$ ed.). Wellington: Government Printer.

Williams, J. (2000). He aha te tikanga Maori. Paper presented to the Mai i te ata hapara hui, Te Wananga o Raukawa, Otaki, New Zealand.

Williams, J. (2004). E Pakihi Hakinga a kai: An examination of pre-contact resource management practice in southern Te Wai Pounamu. Unpublished Doctor of Philosophy in Maori Studies thesis, Otago University, Dunedin, New Zealand.

Williams, L. (2004). Culture and community development: Towards new conceptualizations and practice. Community Development Journal, 39(4), 345-359.

Wilson, D. (2004). Nga kairaranga oranga: The weavers of health and wellbeing: $A$ grounded theory study. Unpublished Doctor of Philosophy in Nursing thesis, Massey University, Palmerston North, New Zealand.

Winch, J. (2005). In our own rights: Black Australian Nurses' Stories. In S. Goold and K. Liddle (Eds.). A vision for our people. Queensland: eContent Management Pty Ltd. 
Winiata, P. (2005). Research at Te Wananga o Raukawa. Paper presented to the Kaihautu Board, Te Wananga o Raukawa, Otaki, New Zealand.

Winiata, P. (2006). Oral conversation. Hui conducted at Ngatokowaru marae, Levin, New Zealand.

Winiata, W. (2000). Matauranga Maori concepts. Paper presented to the Academic Board, Te Wananga o Raukawa, Otaki, New Zealand.

Winiata, W. (2004). Being a tikanga Maori organisation. Paper presented to the Academic Board, Te Wananga o Raukawa, Otaki, New Zealand.

Winiata, W. (2005). Tikanga and kaupapa concepts. Paper presented to the Academic Board, Te Wananga o Raukawa, Otaki, New Zealand.

Winiata, W. (2006). Oral conversation. Hui conducted at Te Wananga o Raukawa, Otaki, New Zealand.

Wootton, A. (1989). Remarks on the methodology of conversation analysis. In D. Roger \& P. Bull (Eds.), Conversation: An interdisciplinary perspective, ( pp. 238-258). Clevedon: Multilingual Matters.

Yazzie, R. (2000). Reclaiming indigenous voice and vision. In M. Battiste (Ed.), Indigenous people and postcolonial colonialism. Vancouver: UBC Press.

Young, TK. (1998). Population health concept and methods. New York: Oxford University Press. 